UNIVERSIDADE DE SÃO PAULO

INSTITUTO DE QUÍMICA DE SÃO CARLOS

Tese de Doutorado

\begin{abstract}
Avaliação das transformações químicas e do potencial agronômico de biofertilizantes líquidos produzidos a partir de resíduos agroindustriais para o manejo sustentável em agricultura orgânica
\end{abstract}




\section{Avaliação das transformações químicas e do potencial agronômico de biofertilizantes líquidos produzidos a partir de resíduos agroindustriais para o manejo sustentável em agricultura orgânica}

Tese de Doutorado apresentada ao Instituto de Química de São Carlos da Universidade de São Paulo como parte dos requisitos para a obtenção do título de Doutor em Ciências

Orientadora: Prof. ${ }^{a}$ Dr. ${ }^{a}$ Maria Olímpia de Oliveira Rezende

Área de concentração: Química Analítica e Inorgânica

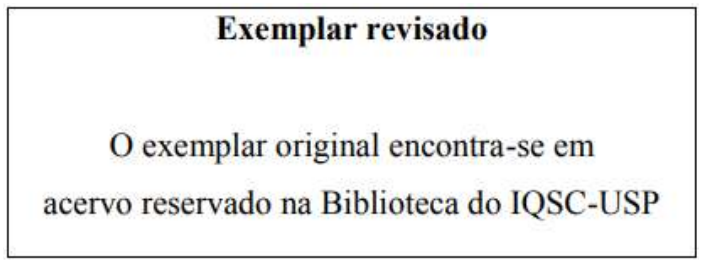

São Carlos - SP 
Autorizo a reprodução e divulgação total ou parcial deste trabalho, por qualquer meio convencional ou eletrônico para fins de estudo e pesquisa, desde que citada a fonte.

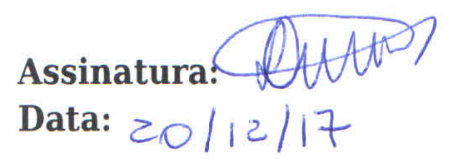

Ficha Catalográfica elaborada pela Seção de Referência e Atendimento ao Usuário do SBI/IQSC

Mendes, Leandro Antunes

Avaliação das transformações químicas e do potencial agronômico de biofertilizantes líquidos produzidos a partir de resíduos agroindustriais para o manejo sustentável em agricultura orgânica / Leandro Antunes Mendes. - São Carlos, 2017.

$170 \mathrm{f}$.

Tese (Doutorado em Química Analítica e Inorgânica) - Instituto de Química de São Carlos / Universidade de São Paulo, 2017.

Orientadora: Profa. Dra. Maria Olímpia de Oliveira Rezende

1. Fertilizantes líquidos. 2. Resíduo sólido orgânico. 3. Alface hidropônica. 4. Agricultura orgânica. 5. Reciclagem. I. Título.

$$
\begin{aligned}
& \text { Referências Bibliagráficas } \\
& \text { conferidas pelo SBIIIQSC. }
\end{aligned}
$$


"A sabedoria da natureza é tal que nãa produz nada de supérflua an incitil."

Nicolau Copérnico 



\section{AGRADECIMENTOS}

A Deus, que está sempre comigo, pela vida e por mais esta conquista alcançada! À professora Dra. Maria Olímpia de Oliveira Rezende pela orientação no desenvolvimento deste trabalho e pela preocupação comigo. Foram tantos anos de convivência que me sinto parte dessa família!!!

À Dra. Maria Diva Landgraf, pelo carinho, ensinamento, palavras de apoio nos momentos difíceis e por ser essa minha mãe São Carlense.

Ao Pesquisador Dan Olk por todo apoio em minha estadia nos Estados Unidos. Agradeço também a Larissa Macedo pelo auxílio no doutorado sanduiche.

Aos meus amados pais Vicente e Selma e a minha irmã, meus verdadeiros ídolos, pelo amor incondicional, força, incentivo e exemplo de caráter. Ao meu afilhado Davizinho, meu incentivo diário para crescer. A toda minha família pelo apoio e força sempre concedidos.

Ao Fábio Rocha, pelo companheirismo, amizade, dedicação e paciência nessa trajetória final, sem você teria sido bem mais difícil!!!

Aos meus amigos do Laboratório de Química Ambiental. Agradeço a todos pela amizade, apoio, ajuda no laboratório e pelos momentos de descontração e também as alunas de Iniciação Científica Maria Chade e Paula Perroni pela essencial ajuda na condução dos experimentos. Meu muito obrigado também ao meu amigo nigeriano Idowu pela amizade e pelo apoio em alguns experimentos.

Aos eternos amigos que fiz em São Carlos ao longo desses oito anos, levarei vocês para sempre comigo. Em especial Virginia Gonzaga pela amor e apoio em tudo, você é minha irmã por escolha. Obrigado por tantos momentos de alegria e cumplicidade que aqui vivemos.

Ao Instituto de Química de são Carlos, pelo espaço e excelente infraestrutura. Aos funcionários, em especial Verô, Andréia, Gislei, Silvia e Carlinho do CAQI, que dedicaram um pouco do seu tempo para que esse título fosse possível.

Ao João Luiz pelo apoio na montagem do sistema hidropônico.

Aos meus irmãos por escolha Robertinho, Andrei, Conrado e Bruno, pela amizade eterna e que mesmo longe estão sempre torcendo por mim desde pequeno.

Ao Laboratório de Saneamento da USP, em especial Júlio pelas análises feitas.

À CAPES pelo auxílio financeiro ao longo desses quatro anos. 


\section{RESUMO}

Nas últimas duas décadas a produção de alimentos utilizando menos insumos sintéticos tem atraído a atenção em muitos campos, como indústria e pesquisa. Esta forma de produção é conhecida como agricultura orgânica e enaltece a ausência de produtos químicos industrializados no sistema produtivo agropecuário. Uma prática útil e de baixo custo é o emprego de biofertilizantes, principalmente pelo fato da crescente procura por tecnologias de produção que apresentem redução de custos e uma melhora na qualidade de vida. Esses fatos, contudo, têm incentivado pesquisadores e produtores rurais a experimentarem biofertilizantes preparados a partir da digestão aeróbia ou anaeróbia de materiais orgânicos em substituição aos fertilizantes minerais. Biofertilizante é a designação dada ao líquido obtido da fermentação aeróbia ou anaeróbia da matéria orgânica e água, cujo produto contém células vivas ou latentes de microrganismos. Assim, neste trabalho, os biofertilizantes foram preparados a partir dos resíduos orgânicos em quatro misturas (esterco bovino + bagaço de laranja $\left(\mathrm{M}_{1}\right)$; cama de frango + bagaço de laranja $\left(\mathrm{M}_{2}\right)$; esterco bovino + cama de frango $\left(M_{3}\right)$ e esterco bovino + cama de frango + bagaço de laranja $\left(M_{4}\right)$, que foram caracterizados em diversas etapas quanto à acidez, condutividade elétrica, concentração de macro e micronutrientes, teor de matéria orgânica e de substâncias húmicas, atributos de qualidade sanitária (coliformes termotolerantes, totais e E. colli) dentre outros e foi testado o potencial agronômico de biofertilizantes associados ao sistema convencional de manejo e a técnica do cultivo hidropônico, com o objetivo de contribuir para o menor consumo de reservas naturais de nutrientes do planeta. Os resultados mostraram que a mistura M3 produziu o melhor biofertilizante por obter os melhores resultados biométricos quando aplicado à cultura, demonstrando que foi possível a produção de um bom biofertilizante em relação ao potencial agronômico.

Palavras Chave: Resíduo sólido orgânico, Reciclagem, Agricultura orgânica, alface hidropônica. 


\begin{abstract}
In the last two decades, there has been a worldwide trend in producing food using less synthetic inputs. This form of production is known as organic agriculture and it praises the absence of industrialized chemicals in the agricultural production system. A useful and low-cost practice is the use of biofertilizers, mainly due to the growing demand for production technologies that reduce costs and provide a better quality of life. However, those facts have encouraged researchers and farmers to experiment biofertilizers prepared from aerobic or anaerobic digestion of organic materials instead of mineral fertilizers. Biofertilizer is the name given to the liquid effluent obtained from aerobic or anaerobic fermentation of organic material and water, and the final product contains live cells or latent microorganisms. In this work, the biofertilizers were prepared from the organic residues in four mixtures (cow manure + orange bagasse (M1), poultry + orange bagasse (M2), cow manure + poultry (M3) and cow manure + poultry + orange bagasse (M4)), which were characterized in several stages regarding acidity, electrical conductivity, concentration of macro and micronutrients, organic material and humic substances content, antibacterial activity (thermotolerant coliforms, total and e-coli) among others, to test the agronomic potential of biofertilizers associated with the conventional management system and the hydroponic cultivation technique, in order to contribute to a lower consumption of natural nutrients reserves from the planet. The results showed that the mixture M3 produced the best biofertilizer, because of the biometric results when it was applied to the crop, demonstrating to be a successful biofertilizer in terms of agronomic potential.
\end{abstract}

Keywords: Organic solid waste, recycling, organic agriculture, hydroponic lettuce. 


\section{LISTA DE SIGLAS E ABREVIAÇÕES}

AF - ácido fúlvico

$\mathrm{AH}$ - ácido húmico

$\mathrm{AL}$ - ácido lático

CaHA - cálcio humificado

CE - condutividade elétrica

COT - carbono orgânico total

CTC - capacidade de troca catiônica

FL - fração leve

FTIR - Infravermelho com transformada de Fourier

IAC - Instituto Agronômico de Campinas

IIE - Instituto Internacional de Ecologia

IN - instrução normativa

IS - índice salino

LQA - Laboratório de Química Ambiental

LRQ - Laboratório de resíduos químicos

$M_{1}$ - esterco bovino + bagaço de laranja

$M_{2}$ - cama de frango + bagaço de laranja

$M_{3}$ - esterco bovino + cama de frango

$\mathrm{M}_{4}$ - esterco bovino + cama de frango + bagaço de laranja

MAPA - Ministério da Agricultura, Pecuária e Abastecimento

MFPA - massa fresca da parte aérea

AHM - ácido húmico móvel

MO - matéria orgânica

MOS - matéria orgânica do solo

MSPA - massa seca da parte aérea 
NKT - nitrogênio Kjeldahl Total

NMP - número mais provável

POM - matéria orgânica particulada

SH - Substâncias húmicas 


\section{LISTA DE FIGURAS}

Figura 1. 1 - Bagaço de laranja - Coleta de bagaço de laranja. 1) lavagem das laranjas; 2) recolhimento na máquina; 3) bagaço após a extração do suco; 4) secagem do resíduo. ...................................................................... 17

Figura 1.2 -Cama de frango - 1) galpão onde os frangos de desenvolvem; 2) coleta da cama de frango; 3) composição da cama de frango; 4) resíduo colocado para secagem.

Figura 1.3 - 1) esterco bovino e 2) vacas em confinamento; 3) coleta do esterco fresco; 4) esterco fresco.

Figura 1. 4 - Preparo dos barris para fermentação dos biofertilizantes (1.preenchimento dos barris com água após a adição das misturas contendo os resíduos; 2. Homogeneização das misturas; 3. Filtragem e coleta 1 dos biofertilizantes; 4. Equipe de apoio no preparo.)

Figura 1.5 - Valores de $\mathrm{pH}$ nas misturas em cada coleta ao longo da fermentação.

Figura 1. 6 - Valores da condutividade elétrica dos biofertilizantes ao longo do processo fermentativo.

Figura 1.7 - Valores da temperatura dos biofertilizantes ao longo do processo fermentativo.

Figura 1.8 - Valores de índice salino em porcentagem dos biofertilizantes nas misturas ao longo do processo fermentativo.

Figura 1.9 - Valores de ácido lático dos biofertilizantes, em graus Dornic, ao longo do processo fermentativo.

Figura 1.10 - Valores do teor de carbono orgânico total das misturas preparadas.

Figura 1. 11 - Valores de nitrogênio (NKT) em $\mathrm{mg} \mathrm{L}^{-1}$ para os biofertilizantes preparados com resíduo orgânico.

Figura 1. 12 - Valores de fósforo na forma de fosfato em $\mathrm{mg} \mathrm{L}^{-1}$ presentes nos biofertilizantes.

Figura 1.13 - Valores de potássio em $\mathrm{mg} \mathrm{L}^{-1}$ presentes nos biofertilizantes.... 37

Figura 1. 14 - Comportamento dos nutrientes comparando cada mistura....... 39

Figura 1.15 - Valores de urease nos biofertilizantes preparados a partir de resíduos orgânicos. ........................................................................ 40

Figura 2.1 - Espectros de FTIR de cada mistura de biofertilizante....................49

Figura 2. 2 - Espectros de FTIR de cada mistura dos AH extraídos dos biofertilizantes.

Figura 2.3 - Espectros de infravermelho de cada mistura de biofertilizante comparada com o respectivo $\mathrm{AH}$ extraído.

Figura 4.1 - Esquema ilustrativo das bancadas hidropônicas e suas respectivas dimensões.

Figura 4. 2 - Montagem dos perfis hidropônicos: 1) limpeza da área onde foram montados os perfis; 2) caixas para solução nutritiva sendo colocadas no chão; 
3) montagem dos tubos dos perfis; 4) esquema dos tubos interligando as caixas com os perfis; 5) aterramento dos tubos de retorno; 6) disposição das caixas já com a parte elétrica das bombas. .............................................. 72

Figura 4.3 - Filtragem dos biofertilizantes já prontos, antes da diluição. ..........73 Figura 4.4 - Monitoramento dos atributos ao longo do desenvolvimento das alfaces.

Figura 4.5 - Preparo das amostras para análise microbiológica. 1) Coleta das alfaces em sacos estéreis; 2) amostras prontas para análise. ....................... 75 Figura 4.6 - Valores de pH ao longo dos 30 dias de crescimento das alfaces. 79 Figura 4. 7 - Valores de condutividade elétrica (CE) ao longo dos 30 dias de crescimento das alfaces.

Figura 4. 8 - Valores de temperatura ao longo dos 30 dias de crescimento das alfaces.

Figura 4.9 - Podridão das raízes sob aplicação de M1 e M2 em alface hidropônica, formação de lodo causada por Pythium aphanidermatum. 81

Figura 4. 10 - Doença causada pelo omiceto Bremia Lactucae Regel, conhecida como míldio

Figura 4.11 - Análise visual das alfaces em relação aos cultivos sob cada mistura.

Figura 4. 12 - Valores de massa fresca da parte aérea em cada mistura. ...... 88 Figura 4. 13 - Valores de circunferência da cabeça sob cultivo de cada mistura.

Figura 4.14 - Valores de comprimento da folha das alface sob cultivo de cada mistura.

Figura 4.15 - Valores de massa fresca da parte aérea das alfaces sob cultivo de cada mistura 90

Figura 4.16 - Número de folhas das alfaces sob cultivo de cada mistura no final do crescimento. 91

Figura 4.17 - Valores de altura do pé de alface sob cultivo de cada mistura. . 91 Figura 5.1 - Mudas das alfaces nos vasos com seus respectivos tratamentos de biomassa.......................................................................................... 100

Figura 5. 2 - Coleta das alfaces após 30 dias....................................... 101

Figura 5. 3 - Comportamento da concentração de nitrogênio (em mg L-1) nos biomassas. 103

Figura 5.4 - Comportamento da concentração de fósforo (em $\left.\mathrm{mg} \mathrm{L}^{-1}\right)$ nas biomassas

Figura 5. 5 - Curva de distribuição granulométrica do solo. .......................... 104

Figura 5.6 - Avaliação do teor de massa fresca em cada tratamento............. 106

Figura 5. 7- Avaliação da circunferência da cabeça em cada tratamento ..... 107

Figura 5.8 - Avaliação do tamanho do pé de alface em cada tratamento...... 107

Figura 5. 9 - Avaliação do tamanho da folha em cada tratamento. ............... 108

Figura 5. 10 - Avaliação do teor de massa seca em cada tratamento........... 108

Figura 5. 11 - Avaliação do número de folhas em cada tratamento ............... 109 
Figura A.1 - Esquema do campo onde foram coletadas as amostras de solos, com os respectivos nomes das áreas e dos números das amostras, sendo:

amostras controle $(1,3,5,7,8,11,12,15,17$ e 19) e amostras com tratamento húmico (amostras 2, 4, 6, 9, 10,13,14, 16, 18 e 20).

126 


\section{LISTA DE TABELAS}

Tabela 1.1 - Valores dos atributos dos resíduos in natura antes da fermentação

Tabela 1. 2 - Valores das médias e dos desvios padrão de cada mistura para valores de $\mathrm{pH}$. Médias seguidas pela mesma letra na coluna não diferem significativamente entre si pelo teste de Tukey $(P<0,05)$.

Tabela 1.3 - Valores das médias e dos desvios padrão de cada mistura para valores de condutividade elétrica $\left(\mu \mathrm{S} \mathrm{cm}^{-1}\right)$. Médias seguidas pela mesma letra na coluna não diferem significativamente entre si pelo teste de Tukey $(\mathrm{P}<0,05)$

Tabela 1.4 - Valores das médias e dos desvios padrão de cada mistura para valores de índice salino, em porcentagem. Médias seguidas pela mesma letra na coluna não diferem significativamente entre si pelo teste de Tukey $(P<0,05)$.

Tabela 1.5 - Valores das médias e dos desvios padrão de cada mistura para valores de ácido lático, em graus Dornic. Médias seguidas pela mesma letra na coluna não diferem significativamente entre si pelo teste de Tukey $(P<0,05)$. 30 Tabela 1. 6 - Valores das médias e dos desvios padrão de cada mistura para valores de carbono orgânico total $\left(\mathrm{mg} \mathrm{L}^{-1}\right)$. Médias seguidas pela mesma letra na coluna não diferem significativamente entre si pelo teste de Tukey $(P<0,05)$.

Tabela 1. 7 - Porcentagem média de matéria orgânica (MO), nitrogênio $(\mathrm{N})$, fósforo $\left(\mathrm{P}_{2} \mathrm{O}_{5}\right)$ e potássio $\left(\mathrm{K}_{2} \mathrm{O}\right)$ na composição, com base na matéria seca de adubos orgânicos.

Tabela 1.8 - Valores das médias e dos desvios padrão de cada mistura para valores de nitrogênio na forma de NKT $\left(\mathrm{mg} \mathrm{L}^{-1}\right)$. Médias seguidas pela mesma letra na coluna não diferem significativamente entre si pelo teste de Tukey $(P<0,05)$

Tabela 1. 9 - Valores das médias e dos desvios padrão de cada mistura para valores de fósforo disponível ( $\left.\mathrm{mg} \mathrm{L}^{-1}\right)$. Médias seguidas pela mesma letra na coluna não diferem significativamente entre si pelo teste de Tukey $(P<0,05)$. . 36 Tabela 1.10 - Valores das médias e dos desvios padrão de cada mistura para valores de potássio disponível $\left(\mathrm{mg} \mathrm{L}^{-1}\right)$. Médias seguidas pela mesma letra na coluna não diferem significativamente entre si pelo teste de Tukey $(P<0,05)$. 38 Tabela 2. 1 - Bandas características dos espectros dos biofertilizantes e dos ácidos húmicos extraídos desses biofertilizantes.

Tabela 3.1 - Média e respectivos desvios-padrão dos valores dos carboidratos encontrados nas misturas (M1, M2, M3 e M4), em $\mu \mathrm{g} \mathrm{g}{ }^{-1}$. 60

Tabela 3. 2 - Média e respectivos desvios-padrão dos valores de cada aminoácido encontrado nas misturas (M1, M2, M3 e M4), em $\mu \mathrm{g} \mathrm{g} \mathrm{g}^{-1}$ 62

Tabela 3.3 - Média e respectivos desvios-padrão dos valores de cada fenol encontrado nas misturas (M1, M2, M3 e M4), em $\mu g g^{-1}$. 
Tabela 3.4 - Média e respectivos desvios-padrão dos valores das variáveis calculadas a partir dos resultados de fenóis em cada mistura (M1, M2, M3 e M4),em $\mu \mathrm{g} \mathrm{g}{ }^{-1}$.

Tabela 4.1 - Valores de condutividade elétrica, $\mathrm{pH}$ e temperatura dos biofertilizantes prontos para serem diluídos e aplicados.

Tabela 4.2 - Atributos analisados conforme a portaria 2914 do MS, para

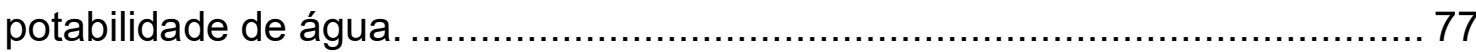

Tabela 4.3 - Valores dos atributos dos biofertilizantes no final do preparo. .... 78 Tabela 4. 4 -Valores dos macronutrientes principais (NPK) nos biofertilizantes no final do preparo.

Tabela 4.5 - Valores de análises microbiológica feitas nas alfaces e nos biofertilizantes.

Tabela 4. 6 - Valores das análises biométricas feitas nas alfaces seguido da análise estatística (MFPA - massa fresca da parte aérea; Circunferência da cabeça; número de folhas; MSPA - massa seca da parte aérea; comprimento da folha; altura do pé).

Tabela 5. 1 - Valores das análises físico-química do solo e das biomassas..102 Tabela 5. 2 - Avaliação da concentração de nitrogênio (em mg.L-1) nas biomassas

Tabela 5. 3 - Avaliação da concentração de fósforo na forma de fosfato (em mg $\left.\mathrm{L}^{-1}\right)$ nos biomassas. 103

Tabela 5.4 - Composição dos grãos dos solos estudados. 105

Tabela 5.5 - Avaliação do comportamento das alfaces tendo em vista o tratamento empregado 106

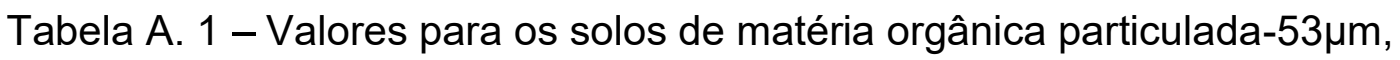

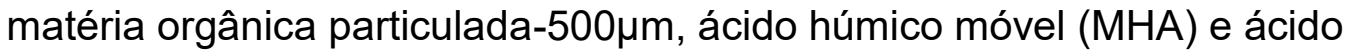
húmico ligado ao cálcio (CaHA), em miligramas $(\mathrm{mg})$. 
RESUMO

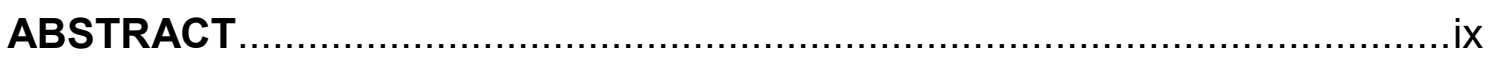

LISTA DE SIGLAS E ABREVIAÇÕES ......................................................

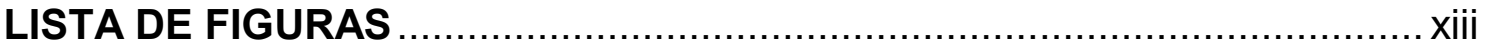

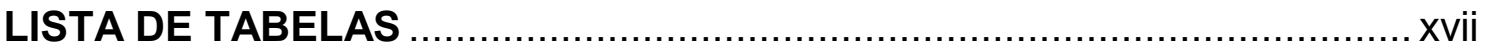

INTRODUÇÃO

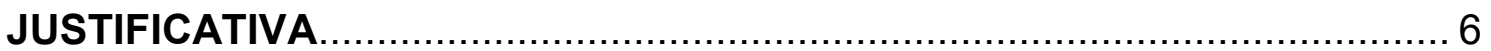

OBJETIVOS

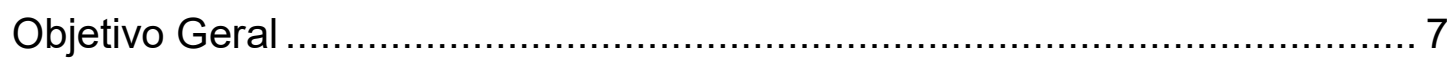

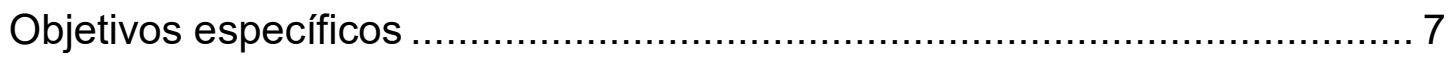

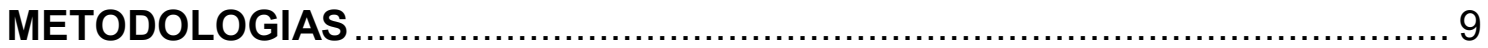

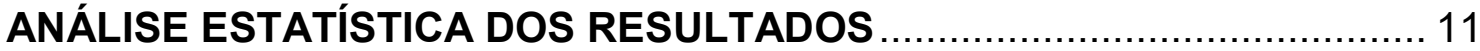

TRATAMENTO DE RESÍDUOS.............................................................. 11

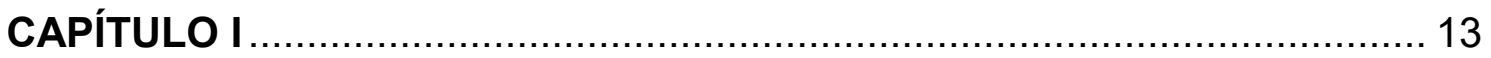

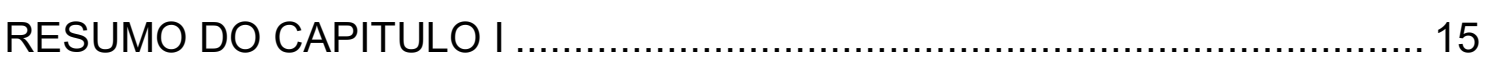

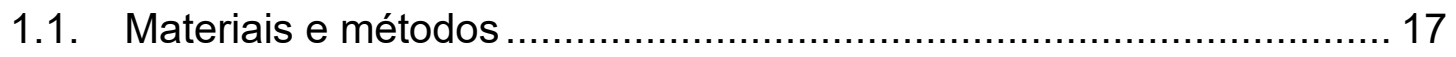

1.1.1. Obtenção dos resíduos orgânicos ............................................ 17

1.1.2. Compostagem líquida ........................................................ 19

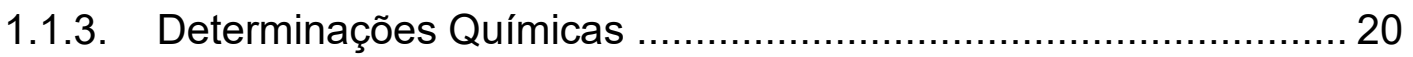

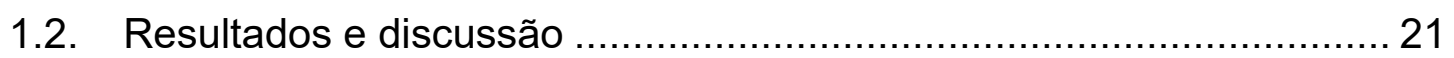

1.2.1. Caracterização dos resíduos in natura ...................................... 21

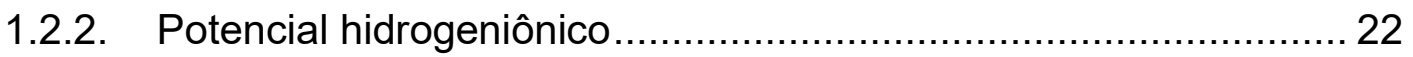

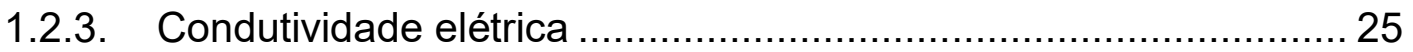

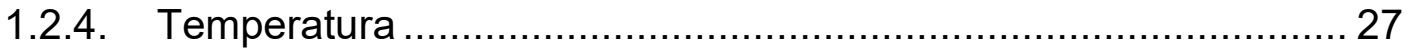

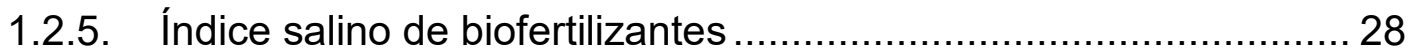

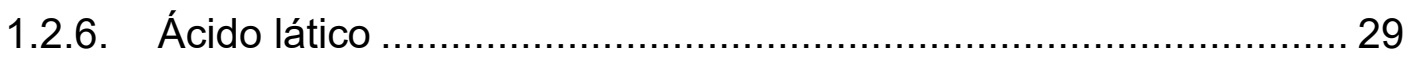

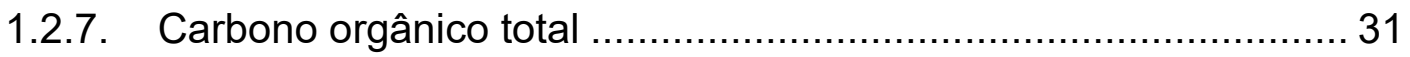

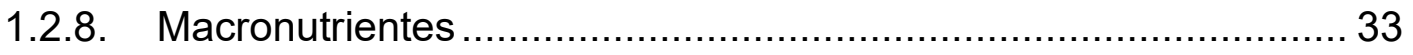

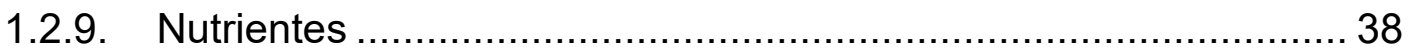

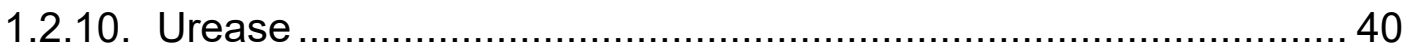




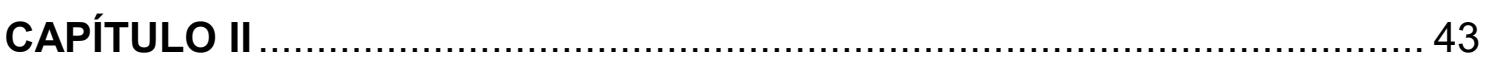

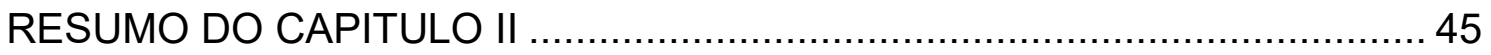

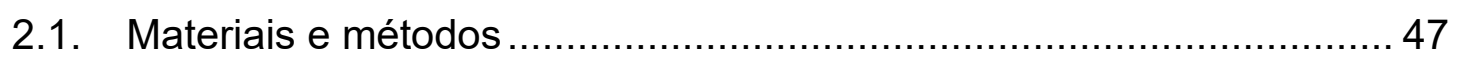

2.1.1. Extração e purificação dos ácidos húmicos .................................. 47

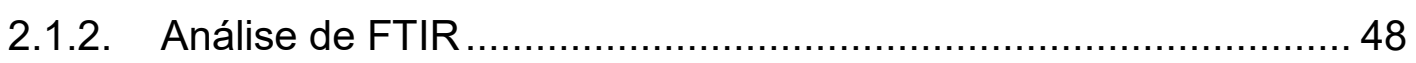

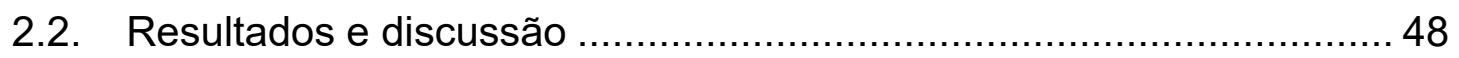

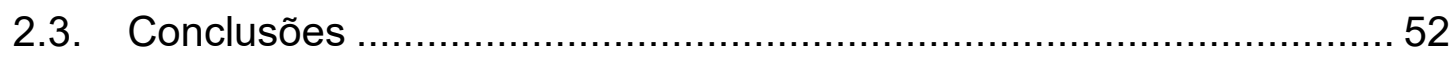

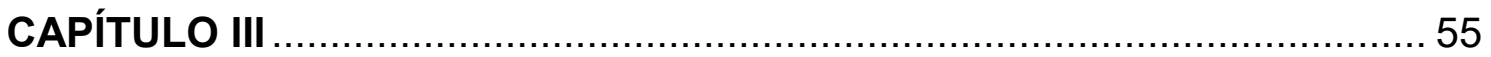

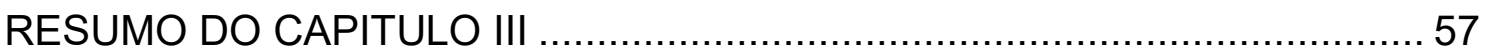

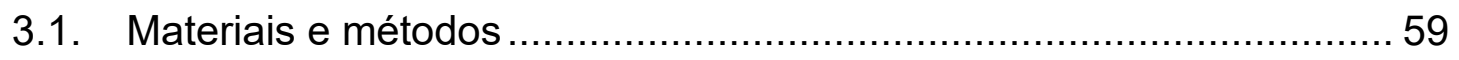

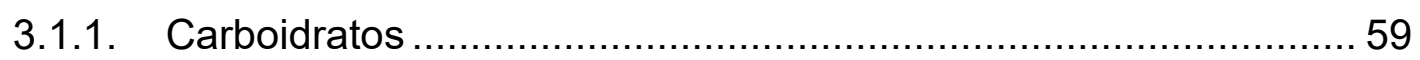

3.1.2. Aminoácidos e amino-açúcares............................................... 59

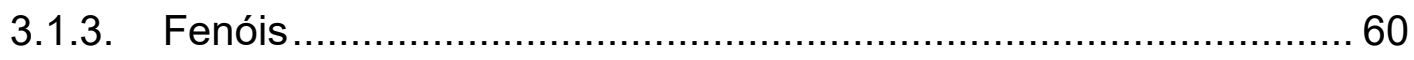

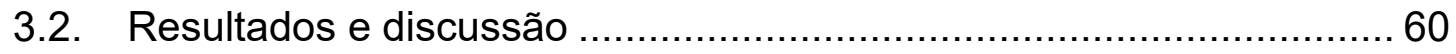

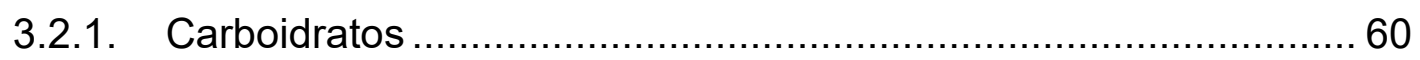

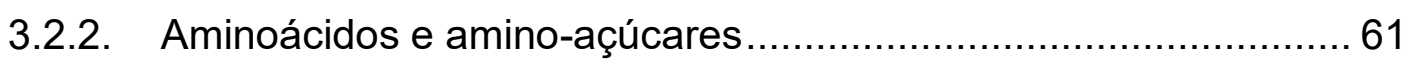

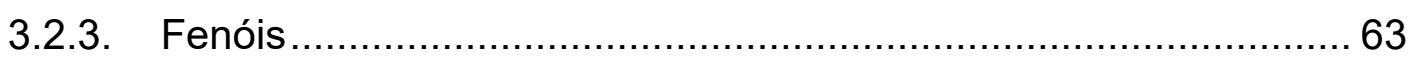

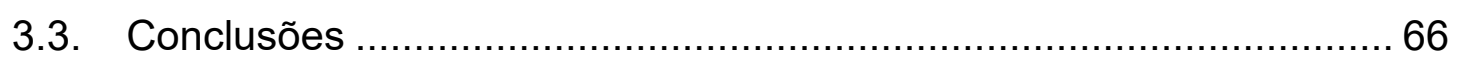

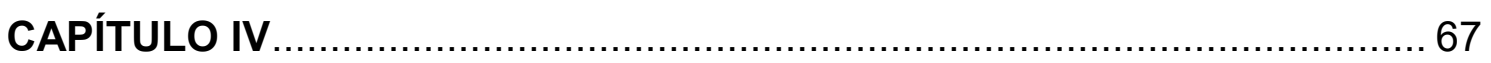

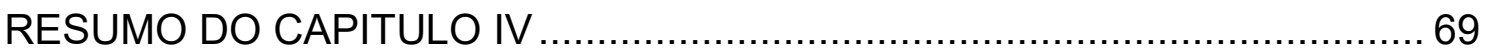

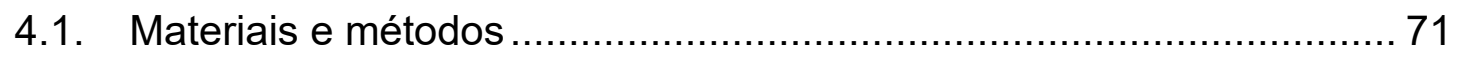

4.1.1. Montagem dos perfis hidropônicos na casa de vegetação ........... 71

4.1.2. Monitoramento da água utilizada no preparo e diluição dos

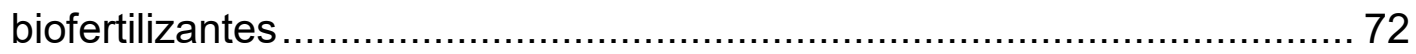

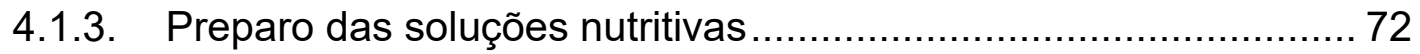

4.1.4. Monitoramento do processo ……........................................... 73

4.1.5. Cultivo das alfaces em hidroponia sob a aplicação dos diferentes

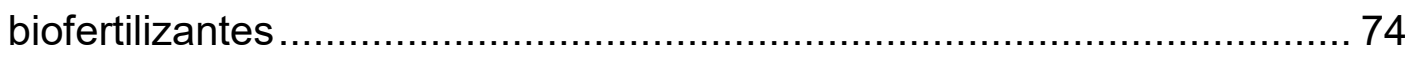

4.1.6. Avaliação biométrica das alfaces............................................ 75 


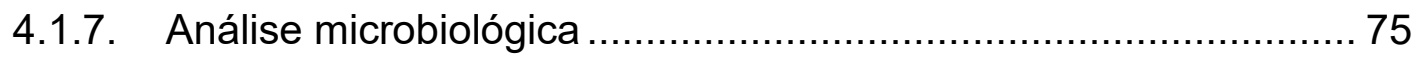

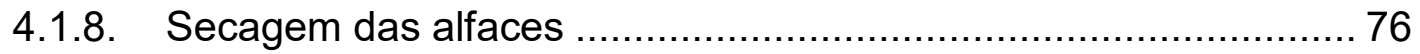

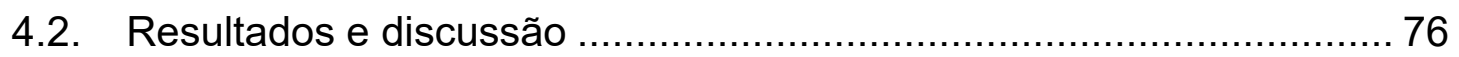

4.2.1. Monitoramento da água utilizada no preparo e diluição dos

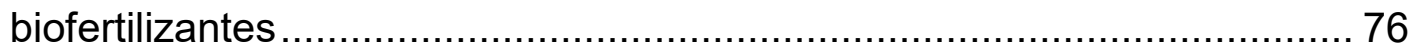

4.2.2. Características finais dos biofertilizantes ................................. 77

4.2.3. Monitoramento dos biofertilizantes ao longo do cultivo das alfaces 78

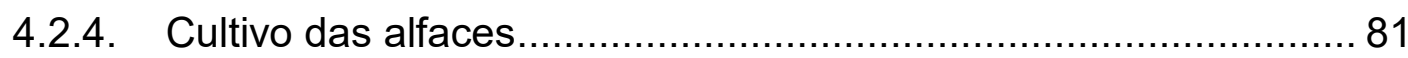

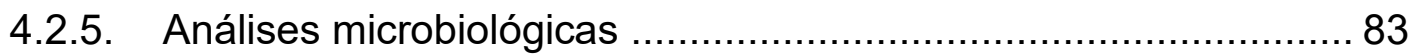

4.2.6. Avaliação biométrica das alface ……………......................... 85

4.2.7. Análise estatística das avaliações biométricas ............................ 87

4.2.8. Atributos biométricos analisados .............................................. 88

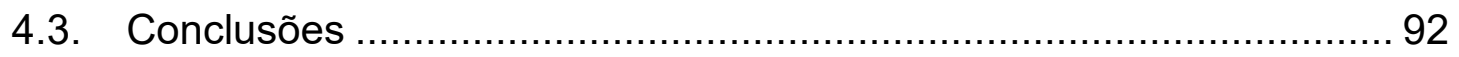

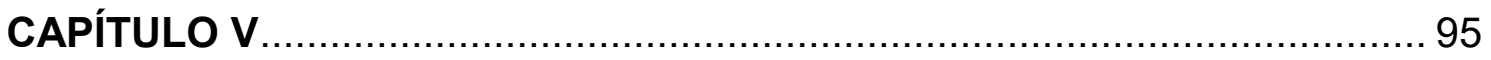

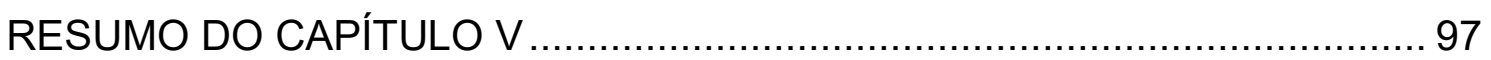

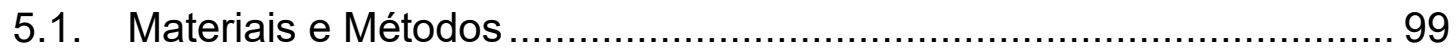

5.1.1. Caracterização físico-química do solo e das biomassas (M1, M2,

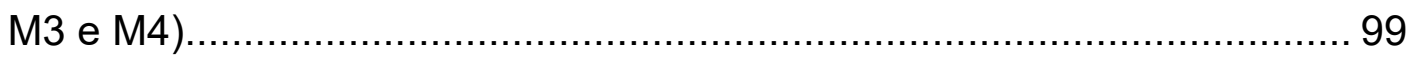

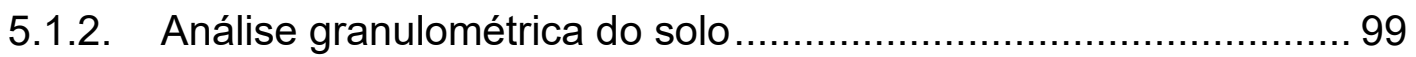

5.1.3. Aplicação das biomassas nas alfaces sob cultivo em vasos ...... 100

5.1.4. Avaliação biométrica das alfaces............................................. 101

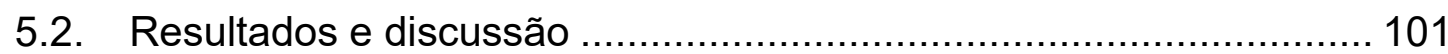

5.2.1. Análises físico-químicas do solo e das biomassas ..................... 101

5.2.2. Análise granulométrica do solo............................................ 104

5.2.3. Avaliação biométrica das alfaces............................................ 105

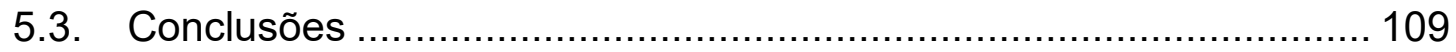

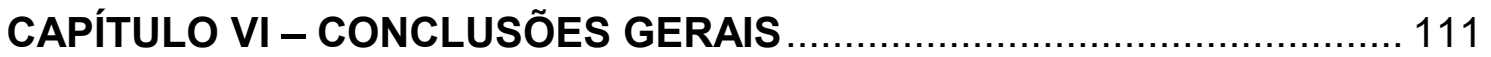

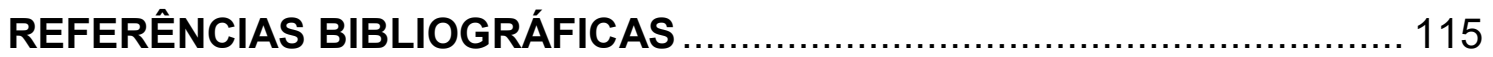

APÊNDICE A 
ANEXO I.

130

ANEXO II..

135 


\section{INTRODUÇÃO}

Atualmente, grandes quantidades de fertilizantes químicos e agrotóxicos estão sendo utilizados pelos agricultores para obtenção de um melhor rendimento de culturas diversas (JOSHI; VIG, 2010). Porém, o uso contínuo e excessivo desses adubos químicos e agrotóxicos altera a estrutura do solo e pode acarretar problemas de saúde aos consumidores (ASGHAR et al., 2006). Os resíduos orgânicos provenientes de atividades rurais, agroindustriais e urbanas têm um grande valor como matéria-prima reciclável na fertilidade do solo, proporcionando retorno financeiro e preservação do meio ambiente (TEDESCO et al., 1999).

A agricultura orgânica desenvolveu-se ao longo do século $X X$, principalmente nas décadas de 80 e 90 (ARAÚJO et al., 2008). Esta dispensa o uso de agrotóxicos e de alguns fertilizantes, sendo muitas as vantagens sobre a agricultura convencional, devido ao impacto positivo sobre o ambiente e sobre a saúde humana. Além disso, pode contribuir para a melhora da renda familiar e propicia a criação de novos empregos (TANAKA et al., 2003).

Entre as fontes de matéria orgânica aplicáveis na agricultura, o uso do composto vindo de resíduo orgânico tratado tem sido visto como uma alternativa de grande sustentabilidade, pois é um material rico em nutrientes utilizáveis pelas plantas, podendo ainda ser usado como fertilizante e condicionador das propriedades físicas, químicas e biológicas do solo (LANDGRAF et al., 2005; GARG et al., 2006).

Outra prática útil e de baixo custo é o emprego de biofertilizantes, principalmente pelo fato da crescente procura por novas tecnologias de produção que apresentem redução de custos e preocupação com a qualidade de vida humana. Esses fatos, contudo, têm incentivado pesquisadores e produtores rurais a experimentarem biofertilizantes preparados a partir da digestão aeróbia ou anaeróbia de materiais orgânicos em substituição aos fertilizantes minerais (ARAÚJO et al., 2007). Além disso, esses produtos podem ser produzidos pelo próprio agricultor, gerando economia de insumos importados e, ainda, promover melhorias no saneamento ambiental (MEDEIROS et al., 2007).

Segundo decreto $N^{\circ} 4.954$, de 14 de Janeiro de 2004, da Presidência da República, que diz respeito à inspeção e fiscalização da produção e do comércio 
de fertilizantes, corretivos, inoculantes ou biofertilizantes destinados à agricultura, um fertilizante orgânico composto é um "produto obtido por processo físico, químico, físico-químico ou bioquímico, natural ou controlado, a partir da matéria-prima de origem industrial, urbana ou rural, animal ou vegetal, isoladas ou misturadas, podendo ser enriquecido de nutrientes minerais, princípio ativo ou agente capaz de melhorar suas características físicas, químicas ou biológicas"; e biofertilizante é um "produto que contém princípio ativo ou agente orgânico, isento de substâncias agrotóxicas, capaz de atuar, direta ou indiretamente, sobre o todo ou parte das plantas cultivadas, elevando a sua produtividade, sem ter em conta o seu valor hormonal ou estimulante". Levando em consideração essas duas definições, tomamos a liberdade de denominar o composto produzido no presente trabalho de biofertilizante líquido.

De acordo com SANTOS (2001), biofertilizante é a designação dada ao efluente líquido obtido da fermentação aeróbia ou anaeróbia da matéria orgânica e água, enquanto MEDEIROS e LOPES (2006) o definem como resíduo final da fermentação de compostos orgânicos que contém células vivas ou latentes de microrganismos (bactérias, leveduras, algas e fungos filamentosos) e de seus metabólicos.

PINHEIRO e BARRETO (2000) relatam que a fertilização com biofertilizante associado ao esterco bovino proporciona maiores produções comerciais nas hortaliças das espécies de pepino, berinjela, tomate, alface e pimentão.

A utilização de biofertilizantes líquidos, na forma de fermentados microbianos enriquecidos, tem sido um dos processos mais utilizados no manejo trofobiótico de pragas e doenças. Em geral, ao serem aplicados nas culturas, atuam como fonte suplementar de micronutrientes para as plantas e podem também contribuir para o aumento da resistência natural das plantas ao ataque de pragas e de patógenos, além de exercerem ação direta sobre fitoparasitas, pela presença de substâncias tóxicas na calda (GONÇALVES et al., 2004; ALVES et al., 2009).

Biofertilizantes aplicados em pulverizações foliares apresentam efeitos nutricionais consideráveis, favorecendo a fixação de flores e de frutos e aumentando a área foliar em diversas culturas, além do efeito hormonal (TANAKA et al., 2003). Porém, SANTOS e AKIBA (1996) relataram que em 
concentrações muito elevadas os biofertilizantes podem afetar desvios metabólicos que estão ligados à produção de substâncias de defesa, retardando, principalmente, o crescimento, a floração ou a frutificação.

O uso de biofertilizantes via foliar nos cultivos de olerícolas pode ser uma alternativa importante para o fornecimento de nutrientes, especialmente para as culturas de ciclo relativamente curto, como a alface. Além de ricos em nutrientes, os biofertilizantes possuem compostos bioativos (MEDEIROS; LOPES, 2006), além de quase todos os macro e micro elementos necessários à nutrição vegetal (SILVA et al., 2007).

A região administrativa central do estado de São Paulo, na qual se encontra o município de São Carlos, caracteriza-se por intensa atividade agropastoril, em que a pecuária de confinamento e extensiva bovina tem papel destacado (Tabela I). Essas atividades geram resíduos orgânicos que podem ser aproveitados como matéria-prima para produção de biofertilizantes, obtendo-se produtos finais com distintas características químicas.

Tabela 1 - Representatividade da produção de cana, laranja e bovinos na região Administrativa Central (RAC) - Fonte SEADE, 2012

\begin{tabular}{lcc}
\hline Variável & $\mathbf{2 0 0 0}$ & $\mathbf{2 0 1 0}$ \\
\hline Cana-de-açúcar - Área Colhida & 272.635 & 374.155 \\
(Em ha) & & \\
\hline Cana-de-açúcar - Produção & 19.720 .798 & 34.401 .088 \\
(Em toneladas) & & \\
\hline Laranja - Área Colhida (Em ha) & 146.797 & 114.983 \\
\hline Laranja - Produção (Em toneladas) & 3.304 .607 & 2.625 .649 \\
\hline Bovinos - Rebanho (Em cabeças) & 363.132 & 245.805 \\
\hline Número de Estabelecimentos da Agropecuária & 3.448 & 3.367 \\
\hline $\begin{array}{l}\text { Proporção de Estabelecimentos da Agropecuária no } \\
\text { estado (Em \%) }\end{array}$ & 18,91 & 12,69 \\
\hline
\end{tabular}

O desenvolvimento da pecuária em confinamento, com elevadas concentrações de animais, tem causado danos aos recursos hídricos e aos solos, uma vez que origina grandes quantidades de estrumes e chorumes, causando preocupação o destino final desses resíduos. Esta situação piora em pastagens com áreas relativamente pequenas onde a disponibilidade de terras 
é insuficiente e não se consegue assimilar a quantidade de dejetos recebidos. Os bovinos criados em sistemas de confinamento geram diariamente um grande volume de dejetos. O manejo inadequado destes, que são ricos em matéria orgânica e agentes patogênicos, pode ser responsável pela poluição de águas superficiais e subterrâneas, devido ao arraste desse material pela ação das chuvas (FURLONG; PADILHA, 1996).

O esterco bovino é um resíduo amplamente usado in natura como adubo orgânico, porém, o processo de fermentação torna-o mais estável além de aperfeiçoar suas propriedades fertilizantes (FIALHO et al., 2007).

A laranja está entre as frutas mais produzidas e consumidas no mundo, sendo que sua produção ultrapassa 80 milhões de toneladas/ano. $O$ bagaço de laranja é o principal subproduto de seu processamento, correspondendo a cerca de $45 \%$ da massa total da fruta e pode se tornar um grande problema para indústria, pois se deteriora muito rápido durante a estocagem (ABECITRUS, 2007). Atualmente, o uso principal dos resíduos da laranja é como complemento para a ração animal. Algumas limitações fazem com que estes resíduos tenham uma utilização restrita, entre elas a grande quantidade de água que contêm, o que acarreta problemas de coleta, transporte e armazenamento. Vários estudos têm proposto outros usos para os resíduos da laranja, incluindo a obtenção de fertilizantes orgânicos, pectina, óleos essenciais, compostos com atividade antioxidante e várias enzimas, incluindo pectinases e amilases (PETRY, 2011).

A avicultura de corte é atualmente uma atividade em expansão e a região de São Carlos passa por transformações, entre elas a implantação de aviários nas pequenas e médias propriedades. A produção de frangos de corte na região, bem como a produção de hortaliças em estufas, são fatos que a colocaram como polo produtivo e deram um novo aspecto para o pequeno produtor rural. $\mathrm{O}$ aumento da atividade de frangos de corte em granjas gera um aumento de resíduos orgânicos, sendo estes utilizados como adubo nas lavouras da região, tendo em sua grande maioria o mínimo de tratamento, como decomposição a céu aberto (NASCIMENTO, 2011).

A utilização dos resíduos de cama de frango para a produção do biofertilizante promove ao mesmo tempo o saneamento ambiental e a diminuição de impactos negativos no solo, na água e no ar (NASCIMENTO, 2011). 
O cultivo de hortaliças com adubos orgânicos tem aumentado nos últimos anos, devido aos custos dos adubos minerais e aos efeitos benéficos que a matéria orgânica proporciona aos solos e ao ambiente, intensamente cultivados com métodos convencionais (VERONKA et al., 2008), além da demanda por alimentos orgânicos. As altas produtividades obtidas com o uso intensivo de capital, de fertilizantes químicos e de agrotóxicos têm sido questionadas não só por suas contradições econômicas e ecológicas, mas também por desprezar aspectos qualitativos importantes da produção vegetal. $O$ fornecimento adequado de nutrientes está diretamente relacionado com a fertilidade, a qual se deve dar especial importância à disponibilidade de nutrientes para a planta, principalmente em relação a fósforo e potássio, em plantas de ciclo curto como a alface (MALAVOLTA et al., 2002).

A adubação foliar na cultura da alface é recomendada como complementação das adubações efetuadas via solo e quando se pretende resposta rápida da cultura, em caso de carências de nutrientes. Nesse sentido, os principais nutrientes aplicados via foliar na alface são $\mathrm{N}, \mathrm{P}, \mathrm{K}, \mathrm{Ca}$ e $\mathrm{Mg}$ (PEREIRA et al., 2010).

A alface (Lactuca sativa L.) é uma das hortaliças mais cultivadas em todo país, é uma espécie herbácea, muito delicada e folhosa de grande expressão econômica, gera rentabilidade rápida ao produtor, pois tem uma ampla adaptabilidade às condições climáticas diversas (VERONKA et al., 2008). É uma das culturas mais produzidas em hidroponia, o que permite seu cultivo durante o ano todo, com grande produtividade, com qualidade e sem o risco de contaminação por microrganismos veiculados pelo solo (RIBEIRO et al., 2007).

A hidroponia é um método de cultivo de plantas que vem se expandindo. Pode-se produzir qualquer espécie vegetal pela técnica em referência. Trata-se de cultivar plantas sem o emprego de solo. Um dos problemas do emprego da hidroponia na produção de alimentos é a adubação, principalmente, quando se empregam apenas produtos prontamente solúveis contendo, portanto, nutrientes prontamente assimiláveis, o que pode desequilibrar a nutrição da planta. O uso de materiais orgânicos na alimentação das plantas, pela liberação lenta de nutrientes, poderia resolver esse impasse. A maior parte das pesquisas tem avaliado soluções nutritivas oriundas de fertilizantes químicos industriais, que 
além de seu custo elevado, são responsáveis pela geração de resíduos poluidores do ambiente (RIBEIRO et al., 2007).

O reaproveitamento de nutrientes após a fermentação de resíduos orgânicos, associado à técnica do cultivo hidropônico, é uma alternativa para reduzir custos na agricultura, além de contribuir para o menor consumo de reservas naturais de nutrientes do planeta.

Não existe formulação única para o preparo do biofertilizante. Os produtos finais vêm sendo usados para fins nutricionais, além de transformarem-se em uma complexa mistura de vitaminas, hormônios de crescimento e antibióticos sem conhecimento científico do efeito ou modo de ação no controle de doenças e pragas (FERNANDES et al., 2000).

\section{JUSTIFICATIVA}

O manejo intensivo do solo, o aumento do uso de água e de pesticidas e fertilizantes tornaram-se práticas comuns para elevar a produção agrícola. No entanto, devido à busca por meios que satisfaçam a população e ao mesmo tempo não prejudiquem o meio ambiente, principalmente, para atender à crescente demanda por alimentos orgânicos, torna-se necessário o desenvolvimento de técnicas de manejo em sistemas de produção intensivos que permitam menor ocupação do solo e redução de insumos agrícolas. A hidroponia é um dos sistemas intensivos mais característicos, sendo uma técnica alternativa de cultivo de plantas com solução nutritiva balanceada na ausência ou na presença de substratos naturais ou artificiais.

Por outro lado, o uso indiscriminado de fertilizantes minerais, tanto em sistemas convencionais de cultivo quanto em sistemas hidropônicos, pode causar sérios danos ao ambiente e provocar escassez precoce de muitas reservas naturais de elementos essenciais à agricultura, fato este que deu origem a muitos estudos e aplicações práticas, com o intuito de diminuir ou substituir os fertilizantes minerais por biofertilizantes ou por fertilizantes orgânicos.

Uma parte desta pesquisa foi realizada no Laboratório Nacional de Agricultura e Meio Ambiente (USDA-ARS), localizado na cidade de Ames, lowa, sob a orientação do Dr. Dan Olk, onde o aluno desenvolveu novos métodos de 
extração da fração orgânica assim como a caracterização bioquímica dos biofertilizantes no tocante a aminoácidos, carboidratos e fenóis. Esse trabalho foi de suma importância uma vez que o Laboratório Nacional de Agricultura e Meio Ambiente, onde o pesquisador Dr. Dan Olk desenvolve seus trabalhos, tem grande experiência na área em questão (CAO et al., 2011; OLK et al., 2009; CREAMER et al., 2012).

Desta forma, pretendeu-se com este projeto o reaproveitamento de nutrientes provenientes da decomposição de resíduos orgânicos, associado à cultura de alface sob diferentes cultivos como sendo uma alternativa para reduzir custos na agricultura, além de contribuir no menor consumo das reservas naturais de nutrientes do planeta. Em se provando a viabilidade econômica e ambiental da produção de hortaliças em sistema hidropônico, associada ao uso de nutrientes provenientes de resíduos orgânicos como solução nutritiva, ter-seá disponível uma alternativa de agricultura racional, que preserva os recursos naturais, extensivamente explorados atualmente, podendo auxiliar na sustentabilidade ecológica.

\section{OBJETIVOS}

\section{Objetivo Geral}

$\checkmark$ Testar 0 efeito dos biofertilizantes produzidos a partir de resíduos orgânicos (esterco bovino, bagaço de laranja e cama de frango) em culturas de alface sob diferentes cultivos.

\section{Objetivos específicos}

$\checkmark$ Preparar e caracterizar os biofertilizantes líquidos produzidos de maneira aeróbia quanto à acidez, condutividade elétrica, concentração de macro e micronutrientes, teor de matéria orgânica e atributos de qualidade sanitária (coliformes totais e termotolerantes);

$\checkmark$ Caracterizar o biofertilizante quanto ao conteúdo de carboidratos, aminoácidos, açúcares aminados, fenóis. 
$\checkmark$ Avaliar a fertilidade do solo em que serão conduzidos os experimentos em vaso (potencial agronômico) após o cultivo;

$\checkmark$ Caracterizar quanto a atributos físico-químicos e microbiológicos as matérias-primas in natura assim como a biomassa produzida ao final da compostagem líquida;

$\checkmark$ Extrair e caracterizar os ácidos húmicos dos biofertilizantes;

$\checkmark$ Avaliar o efeito do biofertilizante via aplicações em culturas de alface sob diferentes cultivos (hidropônico e em vaso) levando-se em consideração a análise dos atributos fitotécnicos (altura, massa fresca da parte aérea, número de folhas e circunferência da cabeça). 


\section{METODOLOGIAS}

As metodologias aplicadas às caracterizações da matéria-prima, do biofertilizantes, do solo e da cultura, assim como da periodicidade dessas caracterizações, estão apresentadas na Tabela II.

Tabela II - Resumo das metodologias utilizadas e a periodicidade de determinação

\begin{tabular}{|c|c|c|c|}
\hline Matéria-prima & Atributo & Periodicidade & Metodologia \\
\hline \multirow{9}{*}{$\begin{array}{l}\text { Esterco bovino; } \\
\text { cama de frango } \\
\text { e bagaço de } \\
\text { laranja in natura }\end{array}$} & $\begin{array}{c}\text { Macro e } \\
\text { micronutrientes }\end{array}$ & Início & IN 28 do MAPA \\
\hline & $\begin{array}{c}\text { Carbono orgânico } \\
\text { total }\end{array}$ & Início & IN 28 do MAPA \\
\hline & CTC & Início & IN 28 do MAPA \\
\hline & Umidade a $65^{\circ} \mathrm{C}$ & Início & IN 28 do MAPA \\
\hline & $\mathrm{pH}$ & Início & IN 28 do MAPA \\
\hline & Sólidos totais & Início & IN 28 do MAPA \\
\hline & $\begin{array}{c}\text { Condutividade } \\
\text { elétrica em } \\
\text { fertilizantes a } 25^{\circ} \mathrm{C}\end{array}$ & Início & IN 28 do MAPA \\
\hline & $\begin{array}{c}\text { Coliformes } \\
\text { termotolerantes e } \\
\text { totais }\end{array}$ & Final & CETESB, 1998 \\
\hline & $\begin{array}{l}\text { Quantificação e } \\
\text { caracterização de } \\
\text { ácidos húmicos }\end{array}$ & Final & $\begin{array}{c}\text { SWIFT, 1996; } \\
\text { STEVENSON, } 1994\end{array}$ \\
\hline \multirow{6}{*}{$\begin{array}{c}\text { Biofertilizantes } \\
\left(\mathrm{M}_{1}, \mathrm{M}_{2}, \mathrm{M} 3, \mathrm{M} 4\right)\end{array}$} & $\begin{array}{c}\text { Macro e } \\
\text { micronutrientes }\end{array}$ & $\begin{array}{l}1^{\circ}, 15^{\circ}, 30^{\circ} \\
45^{\circ} \text { e } 60^{\circ} \text { dia }\end{array}$ & IN 28 do MAPA \\
\hline & $\begin{array}{c}\text { Carbono orgânico } \\
\text { total }\end{array}$ & $\begin{array}{l}1^{\circ}, 15^{\circ}, 30^{\circ}, \\
45^{\circ} \text { e } 60^{\circ} \text { dia }\end{array}$ & IN 28 do MAPA \\
\hline & Ácido lático & $\begin{array}{l}1^{\circ}, 15^{\circ}, 30^{\circ}, \\
45^{\circ} \text { e } 60^{\circ} \text { dia }\end{array}$ & IN 28 do MAPA \\
\hline & $\mathrm{pH}$ & $\begin{array}{l}1^{\circ}, 15^{\circ}, 30^{\circ} \\
45^{\circ} \text { e } 60^{\circ} \text { dia }\end{array}$ & IN 28 do MAPA \\
\hline & $\begin{array}{l}\text { Índice salino de } \\
\text { fertilizante }\end{array}$ & $\begin{array}{l}1^{\circ}, 15^{\circ}, 30^{\circ} \\
45^{\circ} \text { e } 60^{\circ} \text { dia }\end{array}$ & IN 28 do MAPA \\
\hline & $\begin{array}{c}\text { Condutividade } \\
\text { elétrica em } \\
\text { fertilizantes a } 25^{\circ} \mathrm{C}\end{array}$ & $\begin{array}{l}1^{\circ}, 15^{\circ}, 30^{\circ}, \\
45^{\circ} \text { e } 60^{\circ} \text { dia }\end{array}$ & IN 28 do MAPA \\
\hline
\end{tabular}




\begin{tabular}{|c|c|c|c|}
\hline & $\begin{array}{c}\text { Coliformes } \\
\text { termotolerantes e } \\
\text { totais }\end{array}$ & $\begin{array}{l}30^{\circ} \text { e } 60^{\circ} \text { dia } \\
\text { (segunda } \\
\text { montagem) }\end{array}$ & CETESB, 1998 \\
\hline \multirow{11}{*}{$\begin{array}{l}\text { Composto } \\
\text { (biomassa) }\end{array}$} & $\begin{array}{c}\text { Macro e } \\
\text { micronutrientes }\end{array}$ & Final & IN 28 do MAPA \\
\hline & $\begin{array}{c}\text { Carbono orgânico } \\
\text { total }\end{array}$ & Final & IN 28 do MAPA \\
\hline & Relação C/N & Final & IN 28 do MAPA \\
\hline & Umidade a $65^{\circ} \mathrm{C}$ & Final & IN 28 do MAPA \\
\hline & $\mathrm{pH}$ & Final & IN 28 do MAPA \\
\hline & $\begin{array}{c}\text { \% de matéria } \\
\text { orgânica }\end{array}$ & Final & IN 28 do MAPA \\
\hline & $\begin{array}{c}\text { Resíduo sólido e } \\
\text { solubilidade a } 20^{\circ} \mathrm{C}\end{array}$ & Final & IN 28 do MAPA \\
\hline & $\begin{array}{l}\text { Índice salino de } \\
\text { fertilizante }\end{array}$ & Final & IN 28 do MAPA \\
\hline & $\begin{array}{c}\text { Condutividade } \\
\text { elétrica em } \\
\text { fertilizantes a } 25^{\circ} \mathrm{C}\end{array}$ & Final & IN 28 do MAPA \\
\hline & $\begin{array}{c}\text { Coliformes } \\
\text { termotolerantes e } \\
\text { totais }\end{array}$ & Final & CETESB, 1998 \\
\hline & $\begin{array}{c}\text { Extração e } \\
\text { caracterização de } \\
\text { ácidos húmicos }\end{array}$ & Final & $\begin{array}{c}\text { SWIFT, 1996; } \\
\text { STEVENSON, } 1994\end{array}$ \\
\hline \multirow{6}{*}{$\begin{array}{l}\text { Culturas (alface, } \\
\text { alface } \\
\text { hidropônica) }\end{array}$} & $\begin{array}{c}\text { Matéria fresca da } \\
\text { parte aérea }\end{array}$ & Pós-colheita & DAROLT, 2006 \\
\hline & $\begin{array}{c}\text { Circunferência da } \\
\text { cabeça }\end{array}$ & Pós-colheita & DAROLT, 2006 \\
\hline & Número de folhas & Pós-colheita & DAROLT, 2006 \\
\hline & $\begin{array}{c}\text { Matéria seca da } \\
\text { parte aérea }\end{array}$ & Pós-colheita & DAROLT, 2006 \\
\hline & $\begin{array}{c}\text { Macro e } \\
\text { micronutrientes }\end{array}$ & Pós-colheita & NOGUEIRA; SOUZA, 2005 \\
\hline & $\begin{array}{c}\text { Macro e } \\
\text { micronutrientes }\end{array}$ & $\begin{array}{c}\text { Antes e após } \\
\text { colheita }\end{array}$ & NOGUEIRA; SOUZA, 2005 \\
\hline
\end{tabular}




\begin{tabular}{|c|c|c|c|}
\hline \multirow{5}{*}{ Solo } & $\begin{array}{l}\text { Teor de matéria } \\
\text { orgânica }\end{array}$ & $\begin{array}{l}\text { Antes e após } \\
\text { colheita }\end{array}$ & NOGUEIRA; SOUZA, 2005 \\
\hline & CTC total & $\begin{array}{l}\text { Antes e após } \\
\text { colheita }\end{array}$ & NOGUEIRA; SOUZA, 2005 \\
\hline & Teor de carbono & $\begin{array}{l}\text { Antes e após } \\
\text { colheita }\end{array}$ & NOGUEIRA; SOUZA, 2005 \\
\hline & Nitrogênio & $\begin{array}{l}\text { Antes e após } \\
\text { colheita }\end{array}$ & NOGUEIRA; SOUZA, 2005 \\
\hline & $\begin{array}{c}\text { Extração e } \\
\text { caracterização de } \\
\text { ácidos húmicos }\end{array}$ & $\begin{array}{l}\text { Antes e após } \\
\text { colheita }\end{array}$ & $\begin{array}{c}\text { SWIFT, 1996; } \\
\text { STEVENSON, } 1994\end{array}$ \\
\hline
\end{tabular}

\section{ANÁLISE ESTATÍSTICA DOS RESULTADOS}

Todas as determinações, testes e ensaios realizados em bancadas foram feitos em triplicata. As determinações espectroscópicas foram feitas com a quantidade de replicatas necessárias para obtenção de uma boa resolução espectral.

Os dados foram avaliados por meio da análise de variância (VIEIRA, 2006) e a diferença da significância entre as médias foi determinada pelo teste de Tukey $(P<0,05)$, usando o software Origin pro 8 (v.80724-B724).

\section{TRATAMENTO DE RESÍDUOS}

Os resíduos gerados neste trabalho foram encaminhados ao Laboratório de Resíduos Químicos (LRQ) para tratamento adequado.

Um dos aspectos importantes é a eliminação adequada de resíduos químicos gerados, de forma a evitar o descarte inadequado direto ao meio ambiente. Armazenar os resíduos em recipientes adequados para posteriormente encaminhar para o Laboratório de Resíduos Químicos - LRQ do campus 1 da USP de São Carlos foi a estratégia tomada neste trabalho (CAVALHEIRO, 2010).

A aplicação das boas práticas de laboratório associadas à conscientização quanto à prevenção da poluição ambiental é de grande importância na gestão correta de resíduos. Para o correto armazenamento e 
descarte dos resíduos gerados durante o desenvolvimento deste trabalho foram seguidos os procedimentos a seguir:

- Identificação da categoria à qual pertencem os resíduos que se pretendia eliminar;

- Armazenamento dos resíduos em recipientes apropriados de pequeno volume;

- Todos os frascos contendo resíduos foram devidamente etiquetados (data de início do armazenamento, conteúdo e laboratório) e preenchidos juntamente com o Diagrama de Perigo.

- Os resíduos químicos (sólidos ou líquidos), que devido a sua reatividade e toxicidade não podem ser eliminados, como os solventes, devem ser separados dos outros produtos incompatíveis e armazenados até a sua eliminação.

Das substâncias que puderam ser descartadas diretamente na pia foram obedecidas algumas regras, como, apenas compostos solúveis em água ou após diluição; compostos com características ácidas ou básicas foram neutralizados antes do descarte.

Dos materiais que foram descartados no lixo comum podem-se citar, luvas, papéis de filtro e outros descartáveis. Materiais de vidro (frascos, ampolas etc.) que continham produtos químicos foram descartados no lixo de recicláveis. 
Capítulo I

\section{Preparo e caracterização dos biofertilizantes}





\section{RESUMO DO CAPITULO I}

MENDES, Leandro Antunes. Capítulo I - Preparo e caracterização dos biofertilizantes. In: Avaliação das transformações químicas e do potencial agronômico de biofertilizantes líquidos produzidos a partir de resíduos agroindustriais para o manejo sustentável em agricultura orgânica. Tese (Doutorado em Química). Universidade de São Paulo, Instituto de Química de São Carlos, 2017. p. 13-42.

Neste capítulo estão descritos os procedimentos de coleta, preparo e caracterização dos resíduos (cama de frango, esterco bovino e bagaço de laranja) e das misturas (M1 - esterco bovino e bagaço de laranja; M2 - cama de frango e bagaço de laranja; M3 - cama de frango e esterco bovino; M4 - esterco bovino, cama de frango e bagaço de laranja). As coletas dos resíduos foram feitas no município de São Carlos visando a dar um valor agregado para os resíduos gerados na região. Estes foram caracterizados quanto a pH, umidade, sólidos totais, carbono orgânico (COT), capacidade de troca catiônica (CTC) e NPK. Dentre essas caracterizações destaque para o $\mathrm{pH}$, cujo valor mais preocupante é do bagaço de laranja $(\mathrm{pH}=3,65)$ tornando o resíduo ácido e sendo um possível problema para as culturas. Outro fator importante é a CTC, pois todos os resíduos estudados apresentaram uma boa capacidade de trocar nutrientes com o meio, logo, estando mais disponíveis para as culturas. Após a caracterização dos resíduos foi feito o mesmo para as misturas (20\% resíduos $+80 \%$ água), a saber: $\mathrm{pH}$, condutividade elétrica, índice salino, ácido lático, COT e macro e micronutrientes. No geral, para todos os atributos a mistura M3 mostrou-se mais satisfatória no primeiro momento no que diz respeito aos valores ideais necessários para o cultivo da alface hidropônica. 



\subsection{Materiais e métodos}

\subsubsection{Obtenção dos resíduos orgânicos}

Devido à disponibilidade, baixo custo, e à possibilidade de propor uma alternativa ambientalmente viável a alguns resíduos gerados na região de São Carlos, SP, os resíduos orgânicos utilizados foram: bagaço de laranja, cama de frango e esterco bovino.

Figura 1. 1 - Bagaço de laranja - Coleta de bagaço de laranja. 1) Recolhimento na máquina; 2) lavagem das laranjas; 3) bagaço após a extração do suco; 4) secagem do resíduo.
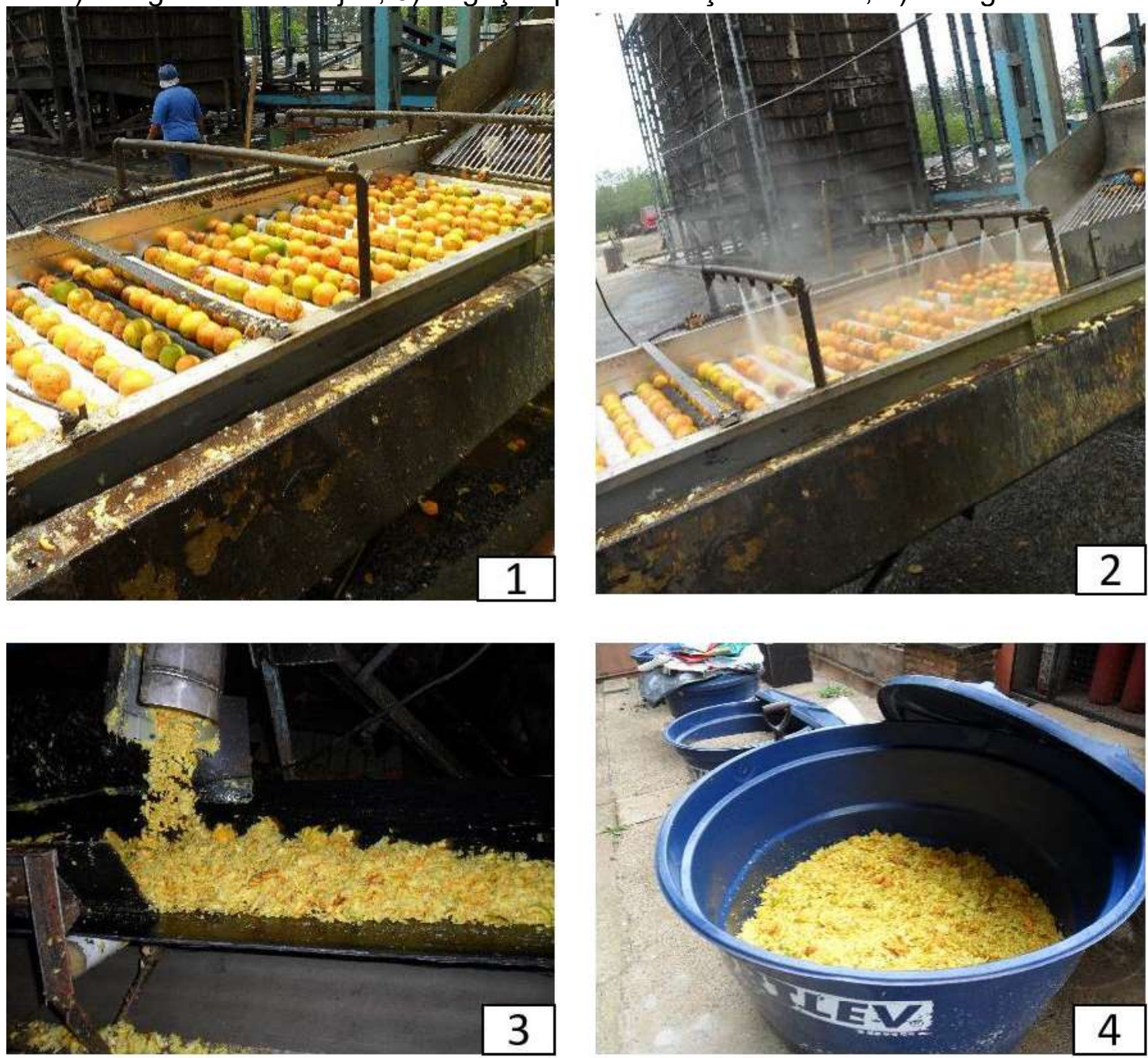

O bagaço de laranja foi proveniente da Fruthil Indústria de Suco de Laranja (Figura 1.1), a cama de frango foi obtida da granja BR Aves (Figura 1.2). Por fim, o esterco bovino foi coletado no curral da Fazenda Santo Antônio da Invernada, proveniente de gado de confinamento (Figura 1.3). Todos os locais de coleta estão localizados em São Carlos-SP. Os experimentos foram conduzidos em barris em ambiente protegido (casa de vegetação) localizada no Campus II da Universidade de São Paulo, em São Carlos-SP. 
Figura 1.2 -Cama de frango - 1) galpão onde os frangos de desenvolvem; 2) coleta da cama de frango; 3) composição da cama de frango; 4) resíduo colocado para secagem.
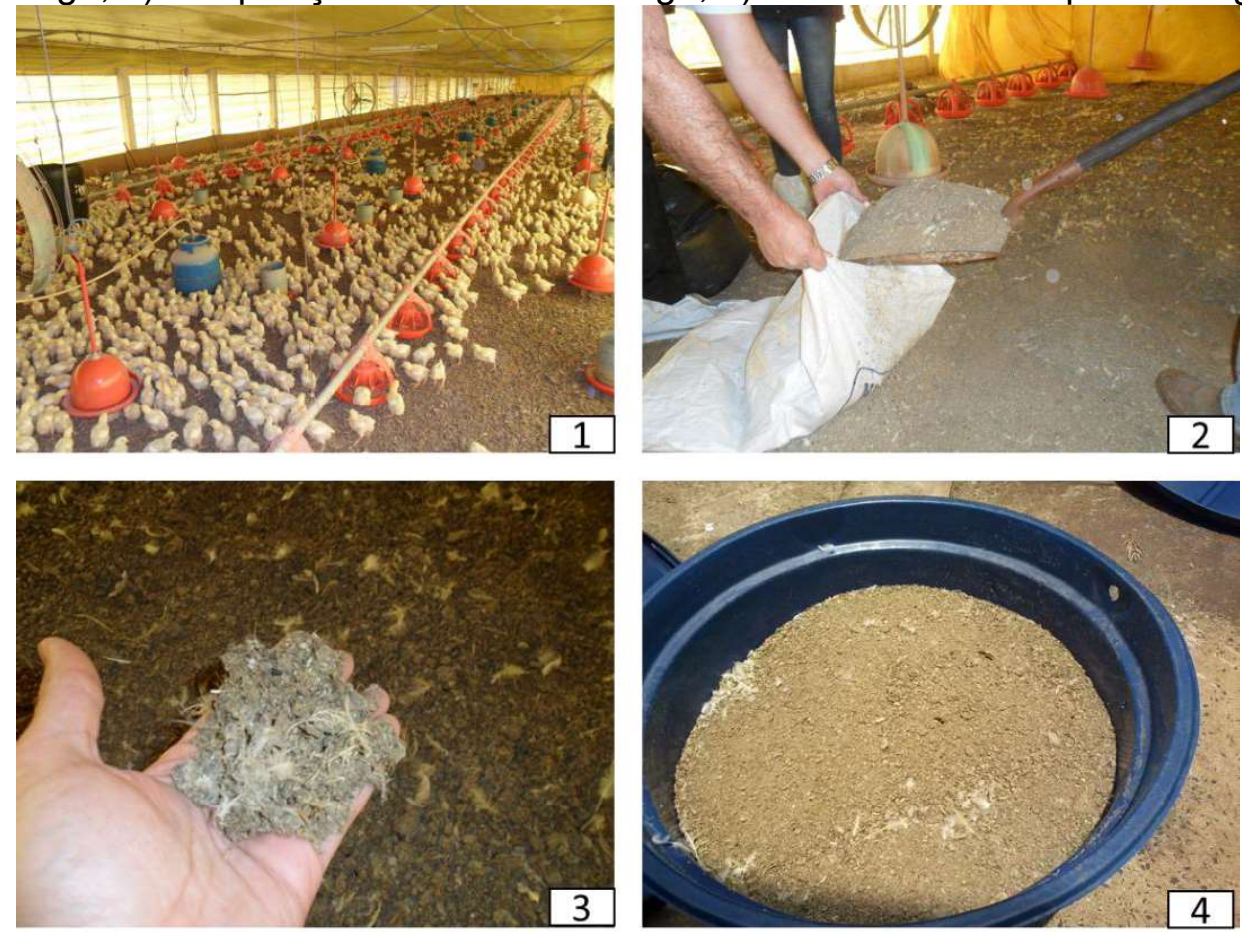

Figura 1.3 - 1) esterco bovino e 2) vacas em confinamento; 3) coleta do esterco fresco; 4) esterco fresco.
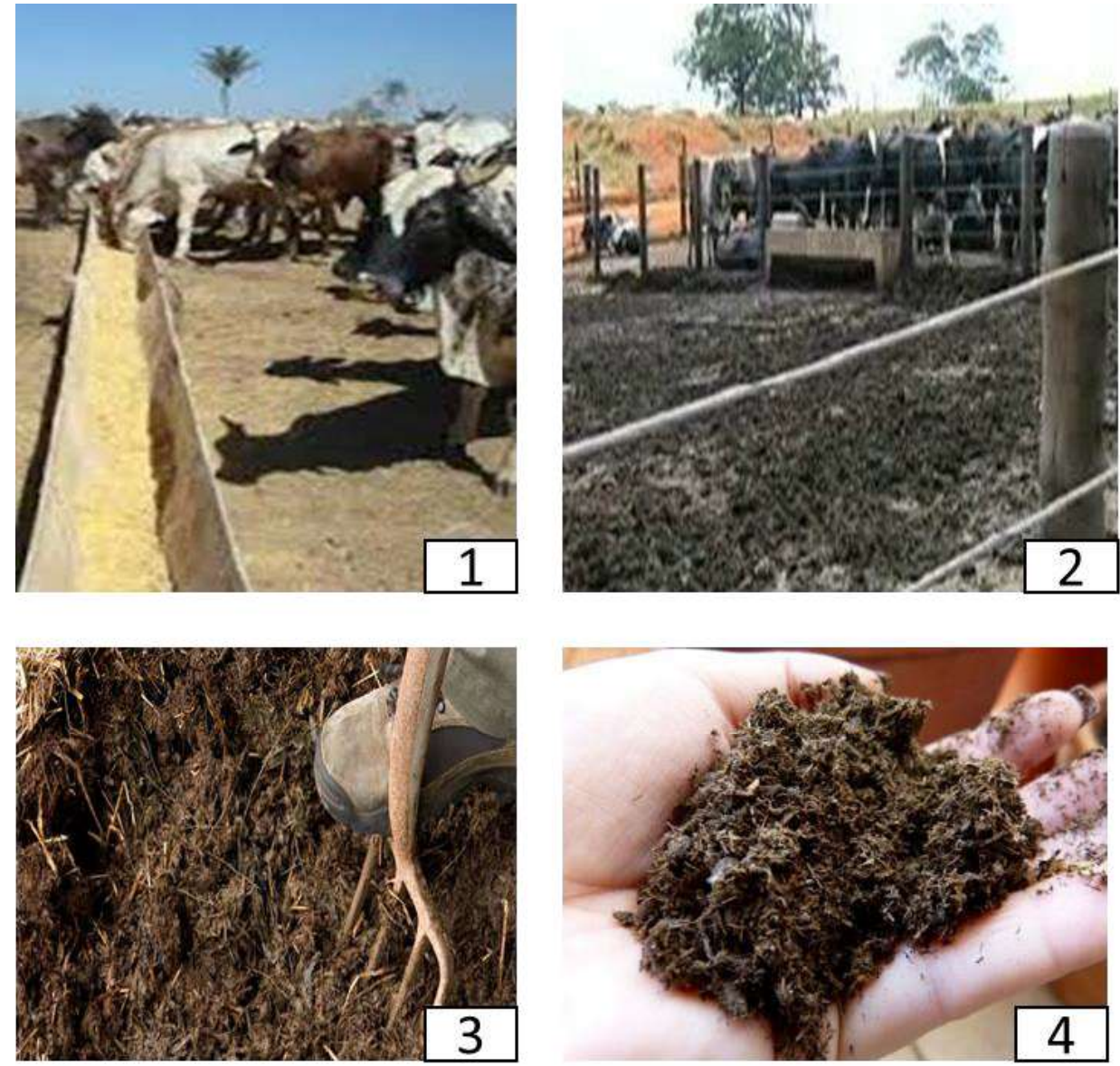


\subsubsection{Compostagem líquida}

Os experimentos foram montados em barris de plástico de 40 litros, aos quais foram adicionados os resíduos. Para a mistura M1, $4 \mathrm{~L}$ de esterco bovino fresco foram misturados com $4 \mathrm{~L}$ de bagaço de laranja, medidos em um béquer e misturados até homogeneização completa, depois disso, foram preenchidos os volumes dos barris com $32 \mathrm{~L}$ de água de abastecimento. Para as outras misturas o procedimento foi o mesmo, variando apenas a composição de cada mistura, sendo: M2 (4 L de cama de frango $+4 L$ de bagaço de laranja); $M 3$ ( $4 L$ de cama de frango $+4 L$ de esterco bovino) e M4 $(2,67 L$ de cama de frango $+2,67 L$ de bagaço de laranja $+2,67 L$ de esterco bovino), em um total para todas as misturas de 8 litros (20\%) da mistura dos resíduos e 32 litros (80\%) de água para completar o volume de 40 litros. Esse preparo foi definido a partir de uma adaptação do biofertilizante proposto por PINHEIRO E BARRETO (1996). Os experimentos M1 a M4 foram feitos em triplicata.

Figura 1. 4 - Preparo dos barris para fermentação dos biofertilizantes (1.preenchimento dos barris com água após a adição das misturas contendo os resíduos; 2 . Homogeneização das misturas; 3 . Filtragem e coleta 1 dos biofertilizantes; 4 . Equipe de apoio no preparo.)
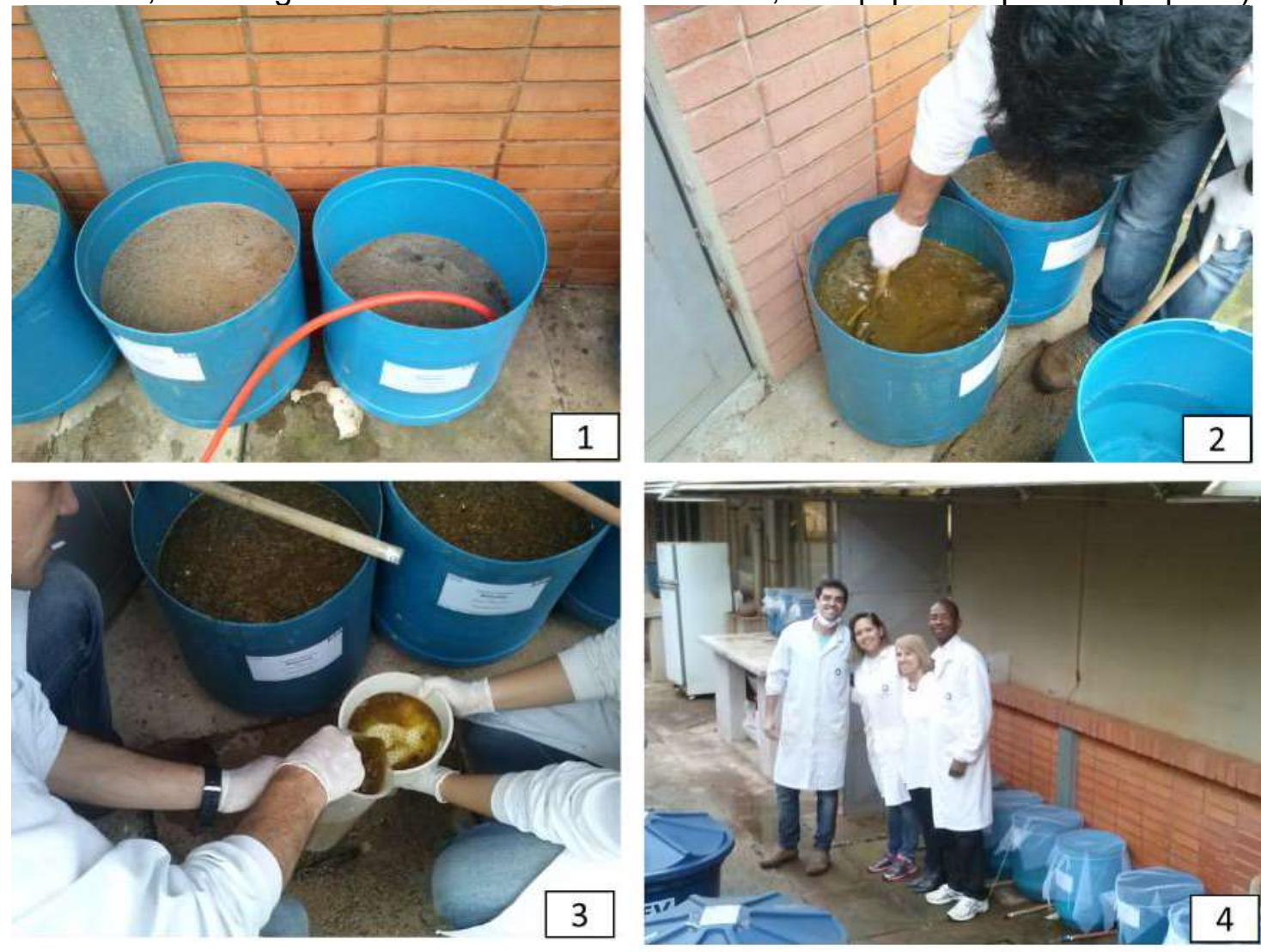

Cada mistura foi homogeneizada duas vezes ao dia, para evitar o apodrecimento e deixada em descanso sem contato com sol ou chuva (Figura 4). Foram coletadas amostras para caracterização no dia 1, 15, 30, 40, 50 e 60 para 
posteriores comparações. Segundo MEDEIROS et al. (2003), o biofertilizante já está pronto para uso a partir do $30^{\circ} \mathrm{dia}$. As coletas foram continuadas para avaliar a estabilização das misturas.

\subsubsection{Determinações Químicas}

Um primeiro experimento foi montado a fim de aperfeiçoar os procedimentos de preparo para evitar problemas maiores quando estes seriam aplicados na cultura de alface e também predizer as características físico-químicas do produto. No final da fermentação foi analisado o composto sólido (biomassa) de suposto grande valor agregado, que é produzido em cada tratamento, assim como o solo a ser utilizado no experimento em vaso.

As análises químicas dos biofertilizantes foram conduzidas no Laboratório de Química Ambiental do Instituto de Química de são Carlos da USP. As alíquotas coletadas nos tempos $\mathrm{t}_{1}, \mathrm{t}_{15}, \mathrm{t}_{30}, \mathrm{t}_{40}, \mathrm{t}_{50}$ e $\mathrm{t}_{60}$ foram determinadas.

Os atributos que foram determinados nas amostras dos biofertilizantes produzidos são aqueles preconizados pelo Instituto Agronômico de Campinas (IAC) seguindo a Instrução Normativa 28 do Ministério da Agricultura, Pecuária e Abastecimento (MAPA) de 27 de Julho de 2007.

Os macro e micronutrientes foram determinados seguindo a Instrução Normativa 28 do Ministério da Agricultura, Pecuária e Abastecimento (IN 28-MAPA) com adaptações no que diz respeito à digestão das amostras. A IN 28 sugere fazer a digestão utilizando o método do ácido cítrico em chapa aquecedora. Essa digestão além de demorada, requer a utilização de reagentes em grande volume, e pode levar a perdas por volatilização. O Laboratório de Química ambiental (LQA), onde as determinações foram feitas, possui um forno de Microondas (SpeedWave four microwave digestion system with Built-in, non-contact temperature and pressure measurement) em sistema fechado que apresenta algumas vantagens em relação ao método do bloco digestor (alta velocidade de decomposição, elevadas temperaturas e pressão, o que minimiza perdas dos analitos voláteis); assim, as amostras foram digeridas utilizando o forno de micro-ondas ao invés do bloco digestor. Depois das digestões, as alíquotas foram determinadas por espectrometria de absorção atômica (IN 28 - MAPA, adaptado; EPA3051).

Adaptação também sofreu a metodologia de determinação do carbono orgânico total (COT). A metodologia sugerida pelo MAPA utiliza o método da dicromatometria. 
Nesse método, utiliza-se um composto altamente tóxico que é o $\mathrm{Cr}$ (VI) na forma de íon dicromato, com grande geração de resíduos. Considerando que no LQA se dispõe de um analisador elementar de carbono (TOC- $\mathrm{V}_{\mathrm{CPH}}$ ) acoplado ao módulo de amostras sólidas, SSM-5000A, da marca SHIMADZU (com detector de combustão), a determinação de COT foi via instrumental (ZOZOLOTTO et al., 2012). Para a determinação, foi pesada uma alíquota de $100 \mathrm{mg}$ da amostra seca e triturada, a qual foi levada ao equipamento de TOC para análise, onde ocorreu a combustão a $680^{\circ} \mathrm{C}$.

As outras determinações foram: $\mathrm{pH}$, porcentagem de matéria orgânica (\%MO), condutividade elétrica em fertilizantes a $25^{\circ} \mathrm{C}\left(\mathrm{CE}_{25}\right)$, índice salino de fertilizantes ácido lático, urease (DELGADO et al., 2004; KANDELER et al., 2011) e matéria orgânica.

Todos os procedimentos relacionados às metodologias das determinações químicas estão referenciados na Tabela 2, do capítulo de Introdução.

\subsection{Resultados e discussão}

\subsubsection{Caracterização dos resíduos in natura}

Para fins de comparação, os resíduos in natura também foram caracterizados. A Tabela 1.1 mostra os resultados das caracterizações feitas com os resíduos antes do preparo dos biofertilizantes.

Tabela 1.1 - Valores dos atributos dos resíduos in natura antes da fermentação

Atributos Esterco bovino Cama de frango Bagaço de laranja

\begin{tabular}{cccc}
\hline $\mathbf{p H ~ e m ~ C a C l} \mathbf{}_{2}$ & $10,27 \pm 0,04$ & $8,48 \pm 0,0$ & $3,65 \pm 0,02$ \\
Umidade (\%) & $9,53 \pm 0,06$ & $11,90 \pm 0,09$ & $9,07 \pm 0,07$ \\
Sólidos totais (mg/kg) & $904.698 \pm 555$ & $881.322 \pm 892$ & $909.281 \pm 700$ \\
$\mathbf{T O C}(\mathbf{m g} / \mathbf{k g})$ & $48.626 \pm 4.932$ & $57.256 \pm 930$ & $70.863 \pm 2.000$ \\
$\mathbf{C T C}(\mathbf{c m o l} / \mathbf{k g})$ & $550 \pm 18$ & $586 \pm 33$ & $777 \pm 30$ \\
$\mathbf{N}$ (mg/kg) & $423 \pm 10$ & $807 \pm 48$ & $316 \pm 40$ \\
$\mathbf{P}$ (mg/kg) & $456 \pm 65$ & $495 \pm 27$ & $325 \pm 60$ \\
$\mathbf{K}$ (mg/kg) & $385 \pm 10$ & $453 \pm 9$ & $251 \pm 32$ \\
\hline
\end{tabular}


Como pode-se observar, cada resíduo apresentou características específicas entre eles. Em se tratando do potencial hidrogeniônico, tanto o esterco bovino quanto a cama de frango apresentam caráter básico devido aos constituintes de sua estrutura. Já o bagaço de laranja apresenta caráter ácido, isso já era esperado pois o resíduo apresenta em sua composição ácido cítrico, tornando esse material orgânico mais ácido.

Outro fator importante de se observar é a capacidade de troca catiônica (CTC), esse atributo nos mostra o quanto o resíduo pode trocar cátions com o meio, ou seja, quanto maior a CTC, espera-se que mais nutrientes vão se solubilizar no meio líquido, o biofertilizante. Como pode-se ver, o bagaço de laranja apresenta o maior valor para CTC, logo, subentende-se que as misturas que apresentam bagaço de laranja podem tornar o biofertilizante mais rico em nutrientes do que aquelas misturas que não contém bagaço. Isso é uma suposição, uma vez que os outros resíduos quando misturados podem interferir na disponibilidade de nutrientes no produto final.

Os valores de nitrogênio, potássio e fósforo são bastante importantes pois esses nutrientes são essenciais para o crescimento das culturas. Pode-se observar a partir da Tabela 1.1 que a cama de frango apresenta os maiores valores para esses macronutrientes, isso não quer dizer que esse resíduo seja o melhor, pois ao longo do processo fermentativo eles podem ter sido mineralizados tornando-os indisponíveis. Mais uma vez vale lembrar que esses atributos mudam após as misturas e, consequentemente, a fermentação, pois uma irá interferir na composição da outra ao longo do processo.

\subsubsection{Potencial hidrogeniônico}

Como pode-se observar na Figura 1.5 , os valores de $\mathrm{pH}$ foram influenciados pela presença de bagaço de laranja nas misturas M1 e M2, nos dois preparos. Isso já era esperado pois como visto na Tabela 1.2, o bagaço de laranja apresenta o menor valor de pH devido à presença de ácido cítrico em sua composição. 
Figura 1.5 - Valores de pH nas misturas em cada coleta ao longo da fermentação.

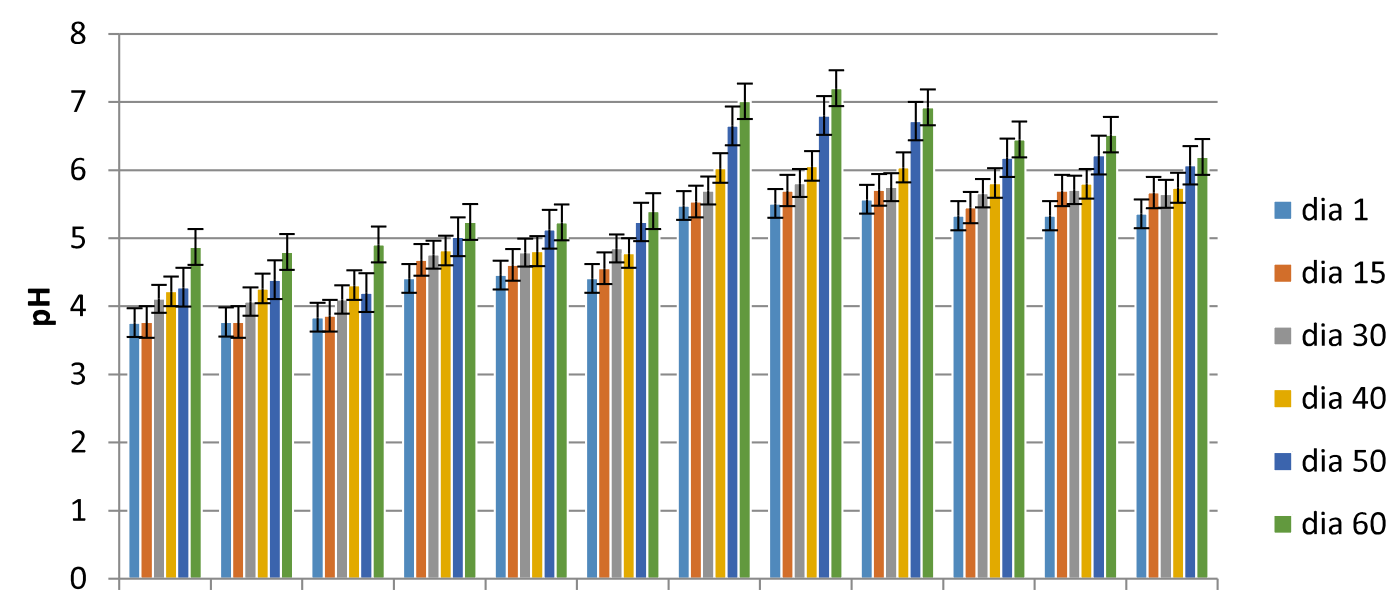

M1-1 M1-2 M1-3 M2-1 M2-2 M2-3 M3-1 M3-2 M3-3 M4-1 M4-2 M4-3

Misturas

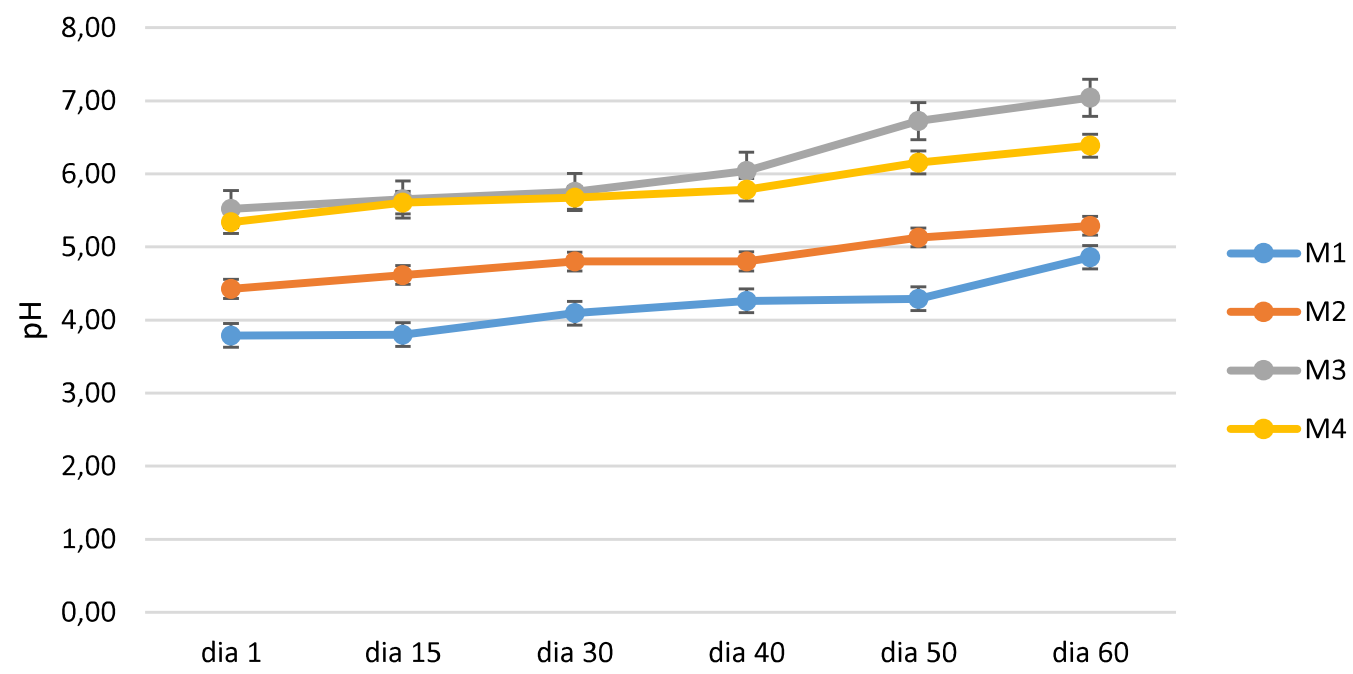

M1 - esterco bovino e bagaço de laranja; M2 - cama de frango e bagaço de laranja; M3 - cama de frango e esterco bovino; M4 - esterco bovino, cama de frango e bagaço de laranja.

Tabela 1. 2 - Valores das médias e dos desvios padrão de cada mistura para valores de pH. Médias seguidas pela mesma letra na coluna não diferem significativamente entre si pelo teste de Tukey $(P<0,05)$.

\begin{tabular}{ccccccc}
\hline & $\mathbf{1}^{\mathbf{a}}$ coleta & $\mathbf{2}^{\mathbf{a}}$ coleta & $\mathbf{3}^{\mathbf{a}}$ coleta & $\mathbf{4}^{\mathbf{a}}$ coleta & $\mathbf{5}^{\mathbf{a}}$ coleta & $\mathbf{6}^{\mathbf{a}}$ coleta \\
\hline M1 & $3,49 \pm 0,04 \mathrm{a}$ & $3,5 \pm 0,05 \mathrm{a}$ & $3,41 \pm 0,07 \mathrm{a}$ & $3,66 \pm 0,30 \mathrm{a}$ & $3,45 \pm 0,07 \mathrm{a}$ & $3,46 \pm 0,09 \mathrm{a}$ \\
$\mathbf{M}$ & $4,32 \pm 0,02 \mathrm{~b}$ & $4,31 \pm 0,06 \mathrm{~b}$ & $4,6 \pm 0,04 \mathrm{~b}$ & $4,76 \pm 0,05 \mathrm{~b}$ & $4,74 \pm 0,06 \mathrm{~b}$ & $4,9 \pm 0,07 \mathrm{~b}$ \\
& & & & & & \\
M3 & $5,64 \pm 0,02 \mathrm{c}$ & $5,72 \pm 0,02 \mathrm{c}$ & $5,65 \pm 0,03 \mathrm{c}$ & $5,57 \pm 0,05 \mathrm{c}$ & $5,51 \pm 0,02 \mathrm{c}$ & $5,76 \pm 0,08 \mathrm{c}$ \\
$\mathbf{M 4}$ & $4,67 \pm 0,06 \mathrm{~d}$ & $5,15 \pm 0,01 \mathrm{~d}$ & $5,27 \pm 0,005 \mathrm{~d}$ & $5,45 \pm 0,08 \mathrm{c}$ & $5,50 \pm 0,06 \mathrm{c}$ & $5,67 \pm 0,14 \mathrm{c}$ \\
\hline
\end{tabular}


$1^{\text {a }}$ coleta: todas as misturas foram estatisticamente diferentes.

$2^{\text {a }}$ coleta: todas as misturas foram estatisticamente diferentes.

$3^{\text {a }}$ coleta: todas as misturas foram estatisticamente diferentes.

$4^{\text {a }}$ coleta: apenas as misturas M3 e M4 foram estatisticamente iguais.

$5^{\text {a }}$ coleta: apenas as misturas M3 e M4 foram estatisticamente iguais.

$6^{\text {a }}$ coleta: apenas as misturas M3 e M4 foram estatisticamente iguais.

As misturas seguiram uma mesma tendência para os valores de $\mathrm{pH}$. Em se tratando das misturas M3 e M4, os valores para ambos os preparos foram semelhantes, uma vez que especialmente para a mistura M3, o processo foi satisfatório, pois nesse caso os valores finais de $\mathrm{pH}$ foram próximos de 7 .

As misturas M1 e M2, por conterem em sua composição bagaço de laranja, apresentaram os menores valores de $\mathrm{pH}$ em todo processo fermentativo. Diferente das outras misturas, M1 e M2 em todas as coletas não apresentaram variação significativa dos valores de $\mathrm{pH}$ no primeiro preparo, mostrando que o resíduo de laranja torna o processo fermentativo mais lento ou até mesmo impedindo-o de acontecer, mesmo que no segundo preparo essa variação tenha sido um pouco maior entre as coletas, ainda assim não foi atingido um valor de $\mathrm{pH}$ próximo de 7 .

A M3, embora tenha um pequeno aumento dos valores de $\mathrm{pH}$ ao longo da coleta, tampouco atingiu a neutralidade no primeiro preparo, mostrando que talvez fosse preciso um tempo maior de fermentação ou até mesmo um controle maior dos fatores externos que afetam o processo. Isso é possível confirmar devido ao fato de que no segundo preparo esses valores foram melhorados atingindo o valor de $\mathrm{pH}$ próximo de 7.

Quando as misturas envolveram os três resíduos (M4), houve um aumento no $\mathrm{pH}$ quando comparada a primeira com a quarta e a última coleta. Isso nos mostra que a fermentação foi eficiente nesse barril, pois como esperado, a mistura foi se tornando neutra.

$\mathrm{Na}$ literatura são citados diferentes valores de $\mathrm{pH}$ para biofertilizantes, estando relacionados com sua composição de preparo, tempo de fermentação e modo de preparo. CAMPOS et al. (2008) utilizando biofertilizante bovino observaram valores de $\mathrm{pH}$ próximos a 8,8 . COSTA et al.(2006) utilizando biofertilizante proveniente de uma mistura de esterco bovino e de galinha constataram pH em torno de 7,2. 


\subsubsection{Condutividade elétrica}

As determinações da condutividade elétrica (CE) dos biofertilizantes foram feitas para servir como estimativa do teor total de sais em solução, baseada no princípio de que a resistência à passagem de corrente elétrica, sob condições padronizadas, diminui proporcionalmente com o aumento da concentração de sais, ou seja, quanto maior a presença de nutrientes em solução, que são condutores, maior será a condutividade. Na Figura 1.6 e Tabela 1.3 pode-se comparar o comportamento da CE em cada mistura.

Tabela 1.3 - Valores das médias e dos desvios padrão de cada mistura para valores de condutividade elétrica $\left(\mu \mathrm{S} \mathrm{cm}^{-1}\right)$. Médias seguidas pela mesma letra na coluna não diferem significativamente entre si pelo teste de Tukey $(P<0,05)$.

\begin{tabular}{ccccccc}
\hline & $\mathbf{1}^{\text {a }}$ coleta & $\mathbf{2}^{\text {a }}$ coleta & $\mathbf{3}^{\text {a }}$ coleta & $\mathbf{4}^{\text {a coleta }}$ & $\mathbf{5}^{\text {a coleta }}$ & $\mathbf{6}^{\text {a coleta }}$ \\
\hline M1 & $2055 \pm 146 \mathrm{a}$ & $3491 \pm 361 \mathrm{a}$ & $3462 \pm 469 \mathrm{a}$ & $3503 \pm 523 \mathrm{a}$ & $4154 \pm 537 \mathrm{a}$ & $2963 \pm 740 \mathrm{a}$ \\
M2 & $5094 \pm 677 \mathrm{~b}$ & $9118 \pm 753 \mathrm{~b}$ & $9166 \pm 724 \mathrm{~b}$ & $9570 \pm 731 \mathrm{~b}$ & $10142 \pm 741 \mathrm{~b}$ & $7846 \pm 622 \mathrm{~b}$ \\
& & & & & & \\
M3 & $6286 \pm 56 \mathrm{c}$ & $11079 \pm 39 \mathrm{c}$ & $10925 \pm 688 \mathrm{c}$ & $10990 \pm 157 \mathrm{c}$ & $11701 \pm 264 \mathrm{c}$ & $8832 \pm 207 \mathrm{~b}$ \\
M4 & $3760 \pm 349 \mathrm{~d}$ & $8004 \pm 354 \mathrm{~b}$ & $7451 \pm 319 \mathrm{~d}$ & $7555 \pm 267 \mathrm{~d}$ & $8030 \pm 191 \mathrm{~d}$ & $6085 \pm 148 \mathrm{c}$
\end{tabular}

$1^{a}$ coleta: todas as misturas foram estatisticamente diferentes.

$2^{\mathrm{a}}$ coleta: todas as misturas foram estatisticamente diferentes.

$3^{a}$ coleta: todas as misturas foram estatisticamente diferentes.

$4^{a}$ coleta: todas as misturas foram estatisticamente diferentes.

$5^{a}$ coleta: todas as misturas foram estatisticamente diferentes.

$6^{\text {a }}$ coleta: apenas as misturas M2 e M3 foram estatisticamente iguais.

Como pode-se observar em todos os barris, a condutividade foi crescente até a coleta 5, mostrando que até essa etapa a fermentação estava disponibilizando nutrientes, que antes estavam ligados aos resíduos. Junto a isso, pode-se ver que a última coleta apresentou menor valor de condutividade que as anteriores em todos os barris, isso é um fator negativo pois pode ser que a partir daí, os nutrientes não estejam disponíveis. Entre as misturas, a M3 foi a que apresentou maior valor de condutividade em todo processo, mostrando uma tendência a ser mais nutritiva em relação às outras. 
Figura 1. 6 - Valores da condutividade elétrica dos biofertilizantes ao longo do processo fermentativo.
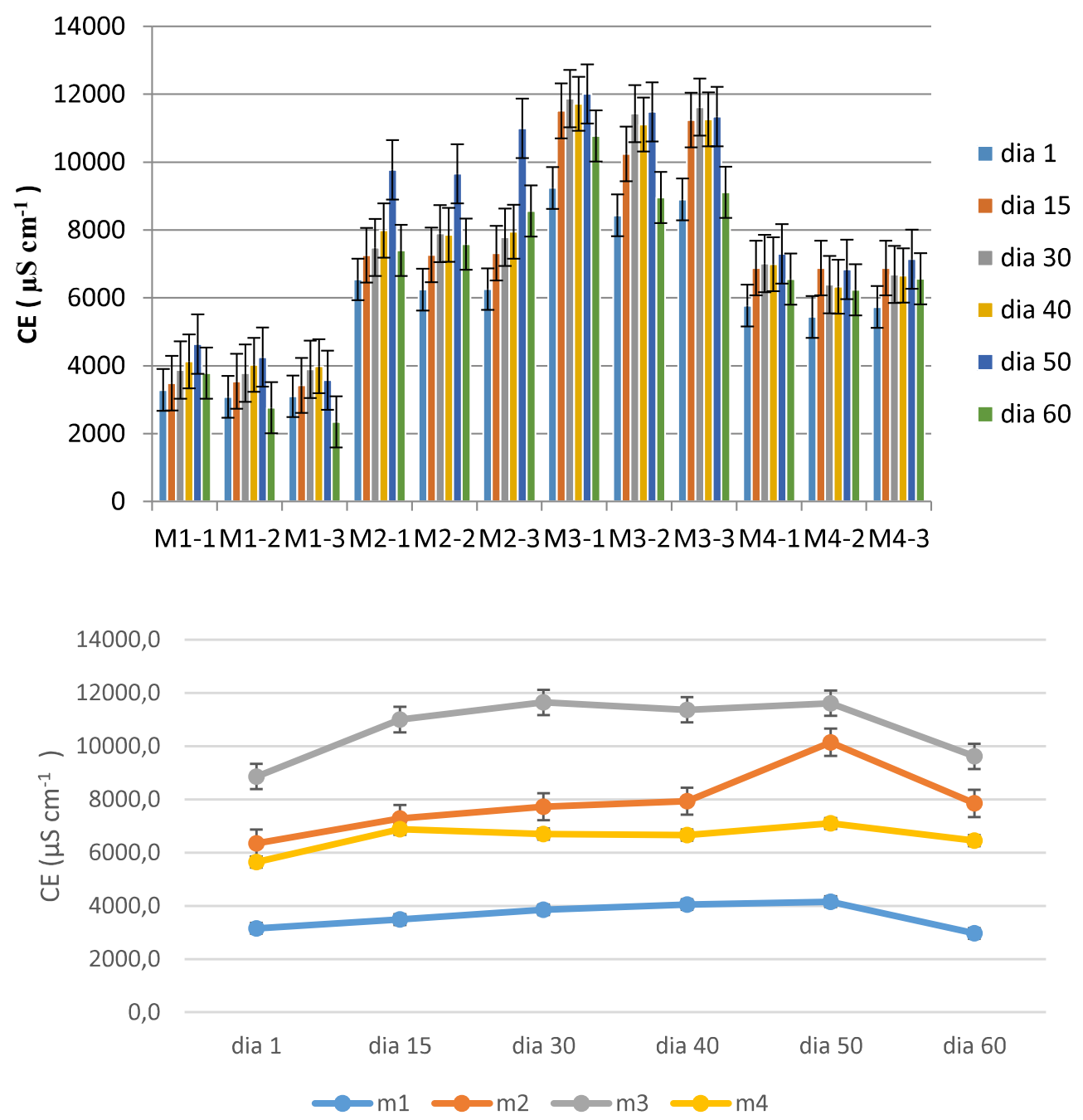

M1 - esterco bovino e bagaço de laranja; M2 - cama de frango e bagaço de laranja; M3 - cama de frango e esterco bovino; M4 - esterco bovino, cama de frango e bagaço de laranja.

Estudos envolvendo biofertilizantes mostram que a condutividade elétrica é bastante influenciada pela composição e forma de preparo assim como o pH. SILVA et al. (2007), utilizando biofertilizante bovino, encontraram valores de condutividade perto de $24.000 \mu \mathrm{S} \mathrm{cm}^{-1}$. Esse valor é bastante elevado perto dos encontrados no presente estudo, chegando a ser dez vezes maior que M1 e duas vezes maior que M3. Esse alto valor é prejudicial quando se trabalha em solos, pois pode afetar a salinidade do mesmo e assim prejudicar o crescimento das culturas. Para hidroponia, esses valores altos podem ser resolvidos diluindo a amostra até valores de condutividade ideal, uma vez que a solução nutritiva deve apresentar valores de condutividade elétrica próximos a $2.500 \mu \mathrm{S} \mathrm{cm}^{-1}$. 


\subsubsection{Temperatura}

Embora a temperatura seja um dos fatores que também sofre influência ao longo do processo, não foi feito o controle desse atributo no primeiro preparo, mas o que se pode perceber é que apesar das variações de acordo com o clima do dia da coleta, esses valores não afetaram o sucesso do processo fermentativo. A Figura 1.7 apresenta os valores da temperatura dos biofertilizantes ao longo do processo fermentativo.

Figura 1.7 - Valores da temperatura dos biofertilizantes ao longo do processo fermentativo.

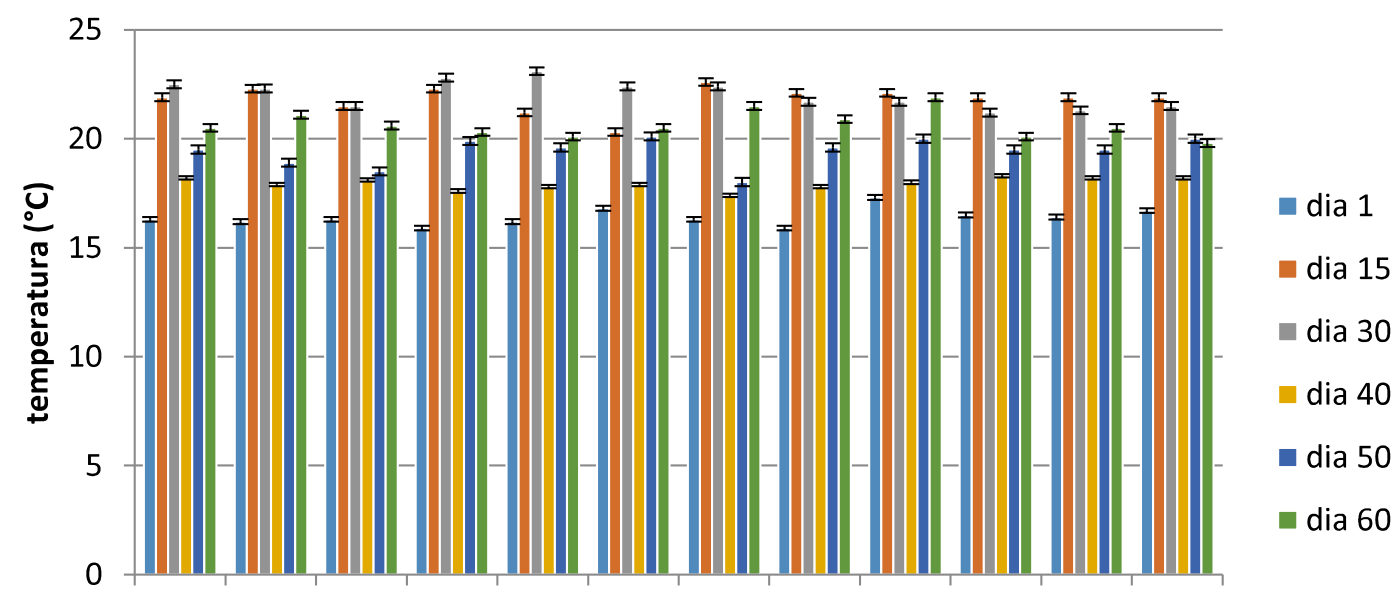

M1-1 M1-2 M1-3 M2-1 M2-2 M2-3 M3-1 M3-2 M3-3 M4-1 M4-2 M4-3

Misturas

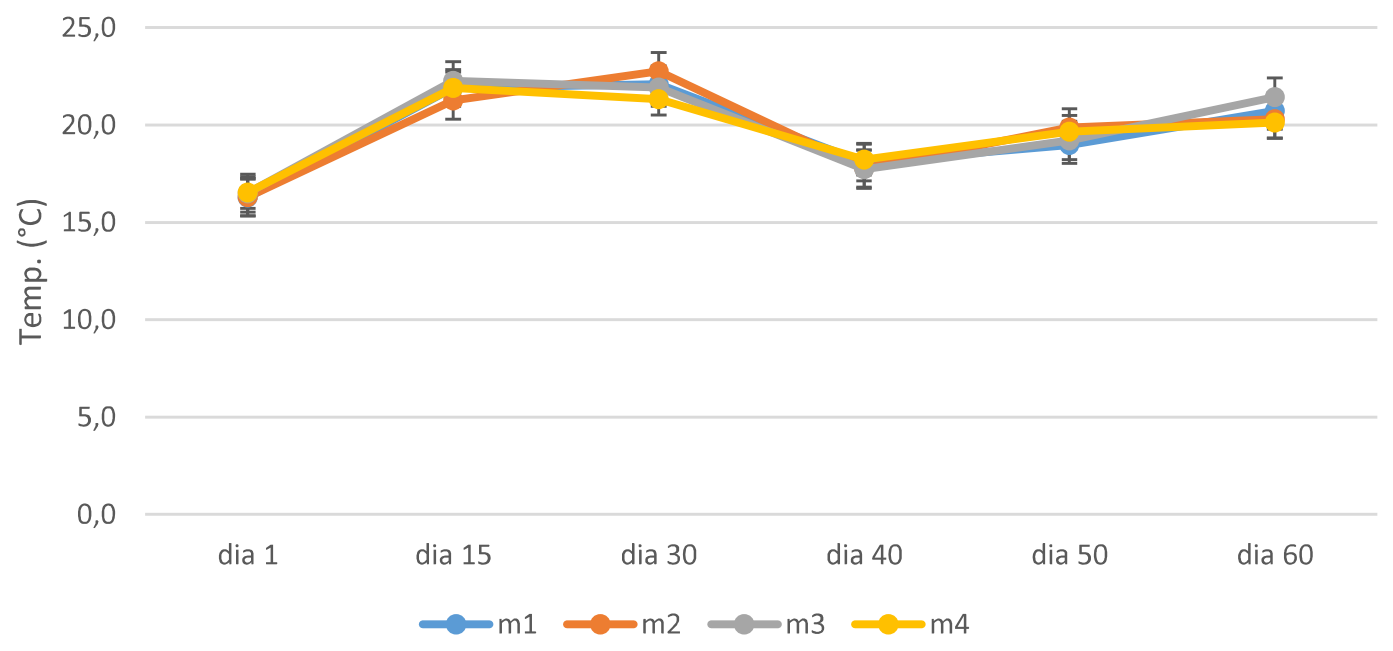

M1 - esterco bovino e bagaço de laranja; M2 - cama de frango e bagaço de laranja; M3 - cama de frango e esterco bovino; M4 - esterco bovino, cama de frango e bagaço de laranja. 


\subsection{5. Índice salino de biofertilizantes}

Esse atributo está ligado à condutividade elétrica dos biofertilizantes e à quantidade de sais disponíveis no meio solúvel, ou seja, uma mistura que contenha mais sais disponíveis espera-se que seja mais nutritiva (Figura 1.8 e Tabela 1.4).

Figura 1.8 - Valores de índice salino em porcentagem dos biofertilizantes nas misturas ao longo do processo fermentativo.
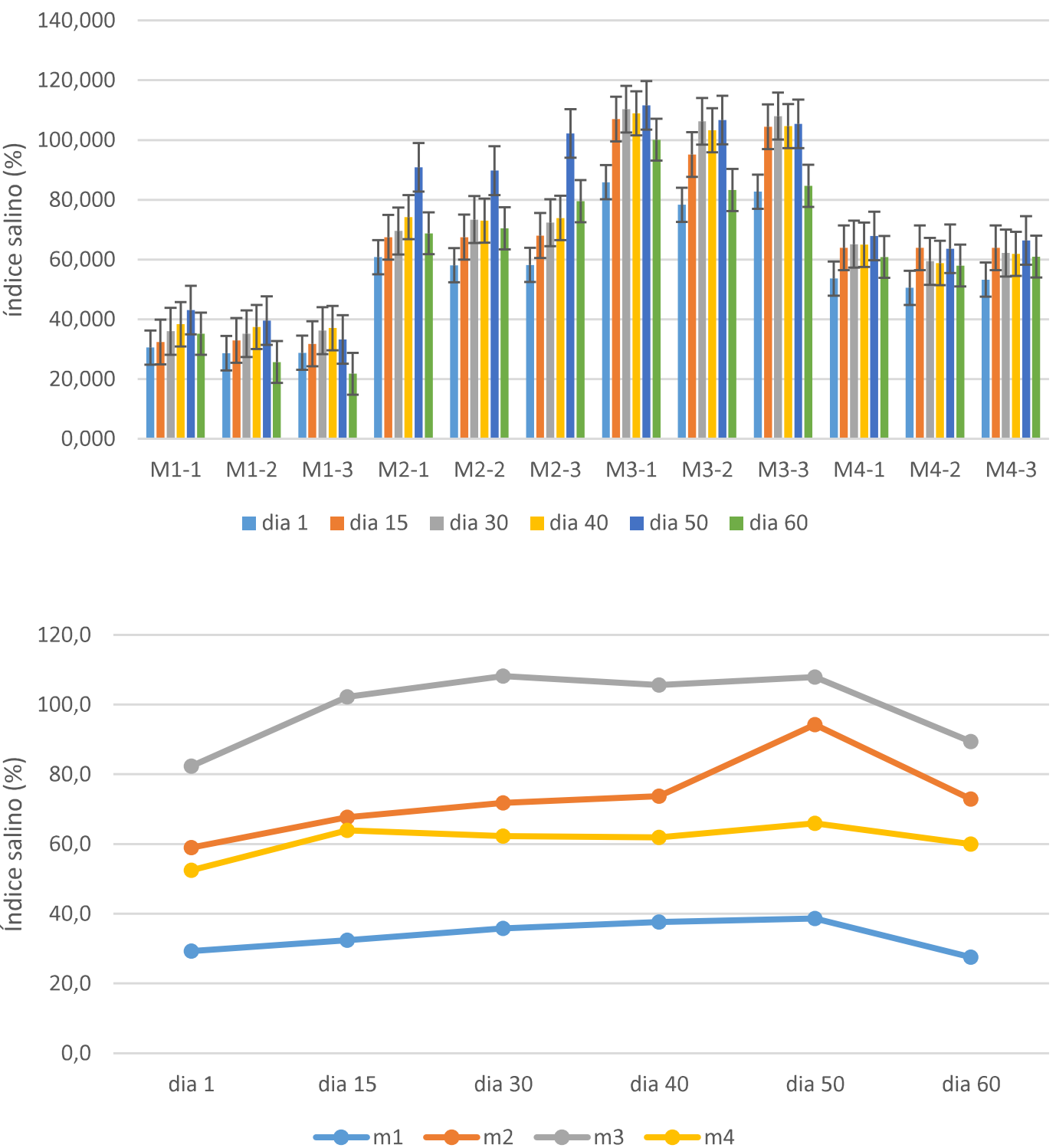

M1 - esterco bovino e bagaço de laranja; M2 - cama de frango e bagaço de laranja; M3 - cama de frango e esterco bovino; M4 - esterco bovino, cama de frango e bagaço de laranja. 
Tabela 1.4 - Valores das médias e dos desvios padrão de cada mistura para valores de índice salino, em porcentagem. Médias seguidas pela mesma letra na coluna não diferem significativamente entre si pelo teste de Tukey $(P<0,05)$.

\begin{tabular}{|c|c|c|c|c|c|c|}
\hline & $1^{\text {a }}$ coleta & $2^{a}$ coleta & $3^{a}$ coleta & $4^{a}$ coleta & $5^{a}$ coleta & $6^{a}$ coleta \\
\hline M1 & $19,10 \pm 1,35 a$ & $32,44 \pm 3,36 a$ & $32,17 \pm 4,36 a$ & $32,56 \pm 4,86 a$ & $38,60 \pm 4,99 a$ & $27,54 \pm 6,87 a$ \\
\hline M2 & $47,34 \pm 6,29 b$ & $84,74 \pm 6,99 \mathrm{bc}$ & $85,20 \pm 6,37 b$ & $88,94 \pm 6,79 b$ & $90,93 \pm 1,22 b$ & $72,92 \pm 5,77 b$ \\
\hline M3 & $58,42 \pm 0,52 c$ & $92,97 \pm 0,37 b$ & $98,21 \pm 0,97 c$ & $92,14 \pm 1,46 b$ & $97,98 \pm 1,18 b$ & $82,08 \pm 1,92 b$ \\
\hline M4 & $34,94 \pm 3,24 d$ & $74,40 \pm 3,29 c$ & $69,25 \pm 2,96 d$ & $70,22 \pm 2,48 \mathrm{c}$ & $74,63 \pm 1,77 c$ & $56,56 \pm 1,38 c$ \\
\hline
\end{tabular}

$1^{\text {a }}$ coleta: todas as misturas foram estatisticamente diferentes.

$2^{\text {a }}$ coleta: as misturas M2 e M3; M2 e M4 foram estatisticamente iguais. A mistura M1 foi diferente das demais.

$3^{\text {a }}$ coleta: todas as misturas foram estatisticamente diferentes.

$4^{\mathrm{a}}$ coleta: apenas as misturas M2 e M3 foram estatisticamente iguais. A mistura M1 foi diferente das demais.

$5^{\text {a }}$ coleta: apenas as misturas M2 e M3 foram estatisticamente iguais. A mistura M1 foi diferente das demais.

$6^{\text {a }}$ coleta: apenas as misturas M2 e M3 foram estatisticamente iguais. A mistura M1 foi diferente das demais.

Os barris que apresentaram as maiores porcentagens de sais foram os que continham M2 e M3. Essas misturas têm em comum a cama de frango como resíduo, que tem em sua composição uma grande variedade de produtos, dentre eles penas, restos de ração, esterco etc., sendo esse um resíduo bastante complexo em relação a sua composição. Essa variedade de resíduo pode contribuir positivamente para que as misturas contendo cama de frango sejam mais nutritivas em relação às outras.

\subsection{6. Ácido lático}

O ácido lático é um produto formado ao longo do processo fermentativo, interferindo no $\mathrm{pH}$ no produto final, logo, onde o processo está ocorrendo espera-se um aumento da concentração do ácido lático e diminuição do $\mathrm{pH}$, inibindo a formação de microrganismos indesejáveis, como os coliformes termotolerantes que tornam o alimento não apto para consumo (BALDUíNO et al., 1999).

A Figura 1.9 e a Tabela 1.5 apresentam os valores de ácido lático ao longo do processo fermentativo. 
Figura 1.9 - Valores de ácido lático dos biofertilizantes, em graus Dornic, ao longo do processo fermentativo.
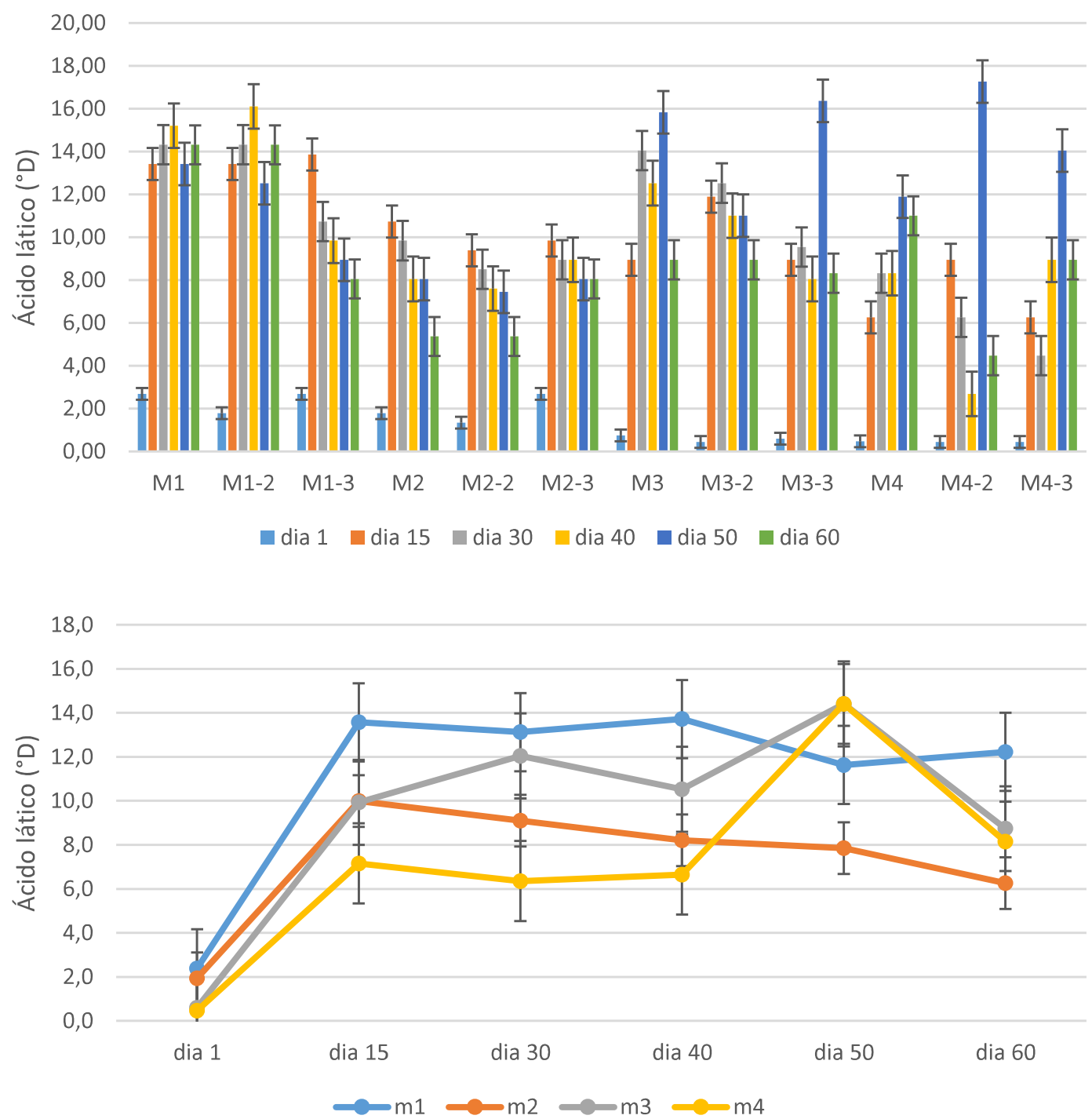

M1 - esterco bovino e bagaço de laranja; M2 - cama de frango e bagaço de laranja; M3 - cama de frango e esterco bovino; M4 - esterco bovino, cama de frango e bagaço de laranja.

Tabela 1.5 - Valores das médias e dos desvios padrão de cada mistura para valores de ácido lático, em graus Dornic. Médias seguidas pela mesma letra na coluna não diferem significativamente entre si pelo teste de Tukey $(P<0,05)$

\begin{tabular}{ccccccc}
\hline & $\mathbf{1}^{\mathrm{a}}$ coleta & $\mathbf{2}^{\mathrm{a}}$ coleta & $\mathbf{3}^{\mathrm{a}}$ coleta & $\mathbf{4}^{\mathrm{a}}$ coleta & $\mathbf{5}^{\mathrm{a}}$ coleta & $\mathbf{6}^{\mathrm{a}}$ coleta \\
\hline M1 & $2,07 \pm 0,52 \mathrm{a}$ & $14,27 \pm 0,06 \mathrm{a}$ & $13,16 \pm 3,05 \mathrm{a}$ & $13,71 \pm 2,64 \mathrm{a}$ & $11,63 \pm 2,36 \mathrm{a}$ & $12,23 \pm 3,61 \mathrm{a}$ \\
$\mathbf{M} 2$ & $1,64 \pm 0,25 \mathrm{ab}$ & $10,29 \pm 1,18 \mathrm{~b}$ & $9,03 \pm 0,57 \mathrm{ab}$ & $8,35 \pm 0,51 \mathrm{~b}$ & $7,85 \pm 0,34 \mathrm{~b}$ & $6,26 \pm 1,54 \mathrm{bc}$ \\
M3 & $1,75 \pm 0,03 \mathrm{ab}$ & $6,11 \pm 0,93 \mathrm{c}$ & $5,18 \pm 0,65 \mathrm{~b}$ & $5,40 \pm 0,37 \mathrm{bc}$ & $5,30 \pm 0,83 \mathrm{bc}$ & $3,58 \pm 0,01 \mathrm{bc}$ \\
M4 & $1,04 \pm 0,25 \mathrm{~b}$ & $5,99 \pm 0,16 \mathrm{c}$ & $5,01 \pm 0,73 \mathrm{~b}$ & $4,74 \pm 0,23 \mathrm{c}$ & $3,58 \pm 0,01 \mathrm{c}$ & $2,98 \pm 0,51 \mathrm{c}$ \\
\hline
\end{tabular}


$1^{\text {a }}$ coleta: as misturas M1, M2 e M3 foram estatisticamente iguais entre si. Foram diferentes apenas as misturas M1 e M4.

$2^{\text {a }}$ coleta: as misturas M3 e M4 foram estatisticamente iguais. Assim, M1 foi diferente de M2, M3 e M4. $3^{\text {a }}$ coleta: as. misturas M2, M3 e M4 foram estatisticamente iguais, assim como M1 foi igual a M2.

$4^{\text {a }}$ coleta: as. misturas M2 e M3; M3 e M4 foram estatisticamente iguais, assim, M1 foi diferente das demais misturas.

$5^{\text {a }}$ coleta: o mesmo que a $4^{\mathrm{a}}$ coleta.

$6^{\text {a }}$ coleta: as misturas M2, M3 e M4 foram estatisticamente iguais entre si, logo, M1 foi diferente das demais misturas

Para os valores de ácido láctico mostrados na Figura 1.9, enquanto a coleta feita no primeiro dia de preparação foi quase zero para todos os barris, a partir da segunda coleta feita no dia 15 de fermentação, os valores aumentaram significativamente chegando perto de $14-16^{\circ} \mathrm{D}$. Esses valores são bastante baixos quando em comparação com o trabalho de RUIZ (2013), em que os valores de ácido láctico eram de cerca de $200^{\circ} \mathrm{D}$. Este valor baixo pode ser devido à falta de adição de sais de nutrientes que tenham sido feitas no trabalho mencionado, contribuindo para o aumento de ácido láctico. Os maiores valores de ácido lático foram na segunda e terceira coleta, o que está de acordo com o trabalho de MEDEIROS et al (2003), que obteve com seus biofertilizantes esse mesmo resultado. Este está diretamente relacionado com a fermentação de biofertilizantes, isto é, quanto mais longa a fermentação, maior será a produção de ácido láctico.

\subsubsection{Carbono orgânico total}

As determinações de carbono orgânico total foram feitas para predizer sobre o teor de matéria orgânica presente nos biofertilizantes (Figura 1.10 e Tabela 1.6). 0 teor de matéria orgânica está diretamente ligado com a fertilidade do produto. 
Figura 1.10 - Valores do teor de carbono orgânico total das misturas preparadas.
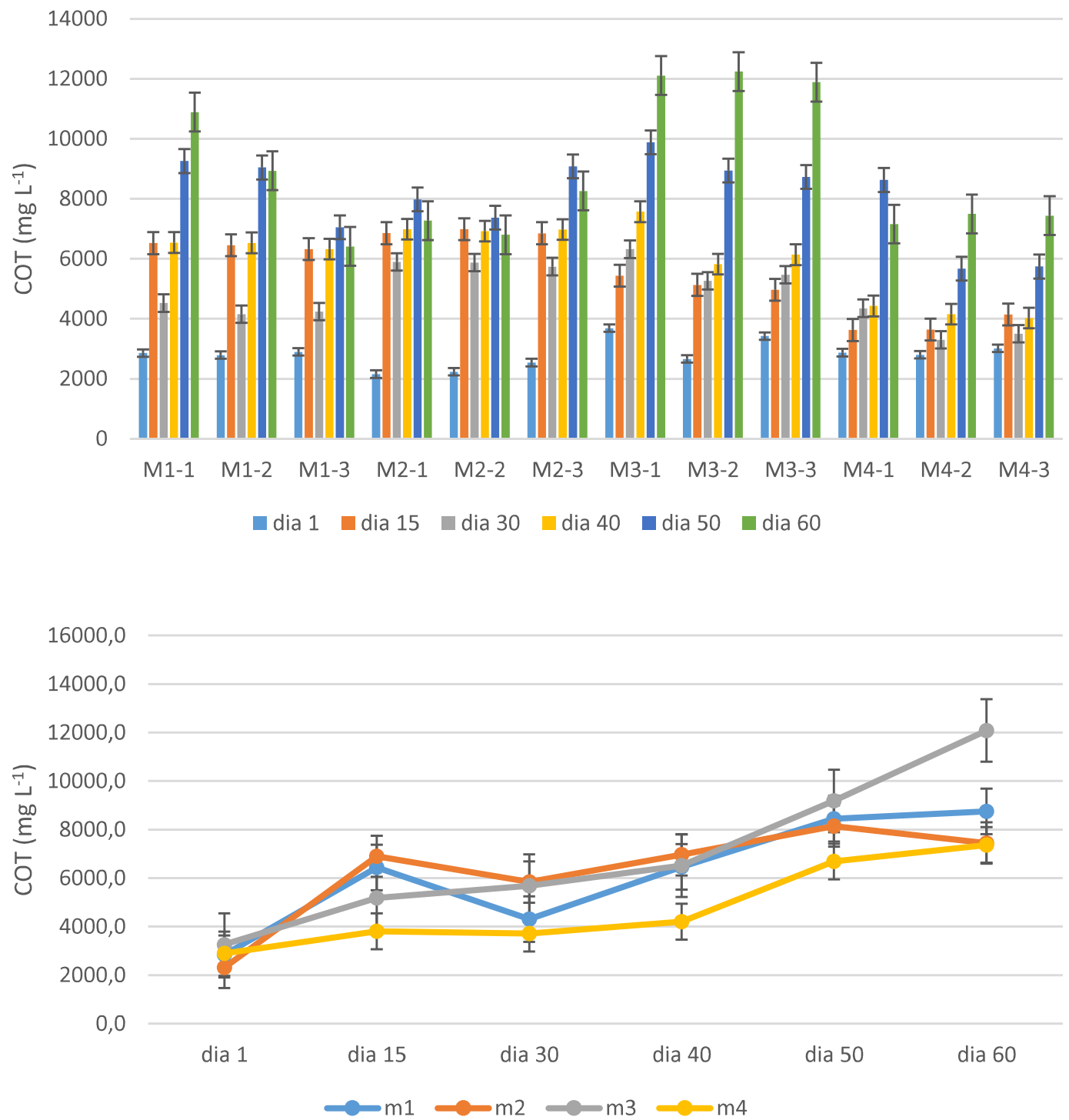

M1 - esterco bovino e bagaço de laranja; M2 - cama de frango e bagaço de laranja; M3 - cama de frango e esterco bovino; M4 - esterco bovino, cama de frango e bagaço de laranja.

Tabela 1. 6 - Valores das médias e dos desvios padrão de cada mistura para valores de carbono orgânico total $\left(\mathrm{mg} \mathrm{L}^{-1}\right)$. Médias seguidas pela mesma letra na coluna não diferem significativamente entre si pelo teste de Tukey $(P<0,05)$.

\begin{tabular}{ccccccc}
\hline & $\mathbf{1}^{\mathrm{a}}$ coleta & $\mathbf{2}^{\mathbf{a}}$ coleta & $\mathbf{3}^{\mathbf{a}}$ coleta & $\mathbf{4}^{\mathrm{a}}$ coleta & $\mathbf{5}^{\text {a }}$ coleta & $\mathbf{6}^{\mathbf{a}}$ coleta \\
\hline M1 & $2373 \pm 58 \mathrm{ab}$ & $8046 \pm 23 \mathrm{a}$ & $3091 \pm 65 \mathrm{a}$ & $3169 \pm 35 \mathrm{a}$ & $8450 \pm 12 \mathrm{a}$ & $8745 \pm 22 \mathrm{a}$ \\
$\mathbf{M} 2$ & $1893 \pm 51 \mathrm{ab}$ & $8674 \pm 54 \mathrm{a}$ & $2391 \pm 30 \mathrm{ab}$ & $8711 \pm 80 \mathrm{~b}$ & $8144 \pm 86 \mathrm{a}$ & $7445 \pm 74 \mathrm{ab}$ \\
$\mathbf{M} 3$ & $2728 \pm 24 \mathrm{a}$ & $4512 \pm 32 \mathrm{~b}$ & $1547 \pm 64 \mathrm{~b}$ & $6065 \pm 25 \mathrm{ab}$ & $5977 \pm 26 \mathrm{~b}$ & $5736 \pm 33 \mathrm{ab}$ \\
$\mathbf{M 4}$ & $1503 \pm 19 \mathrm{~b}$ & $4441 \pm 30 \mathrm{~b}$ & $1629 \pm 18 \mathrm{~b}$ & $6488 \pm 13 \mathrm{ab}$ & $5546 \pm 46 \mathrm{~b}$ & $4957 \pm 35 \mathrm{~b}$ \\
\hline
\end{tabular}


$1^{\text {a }}$ coleta: as misturas M1, M2 e M3 foram estatisticamente iguais entre si. Foram diferentes apenas as misturas M3 e M4.

$2^{\mathrm{a}}$ coleta: as misturas M1 e M2; M3 e M4 foram estatisticamente iguais. Assim, M1 foi diferente de M3 eM4, assim como M2 foi diferente de M3 e M4.

$3^{\text {a }}$ coleta: as misturas M2, M3 e M4 foram estatisticamente iguais entre si. Assim, M1 foi diferente de M3 eM4.

$4^{\mathrm{a}}$ coleta: as misturas M2, M3 e M4 foram estatisticamente iguais entre si. Assim, M1 foi diferente apenas de M2.

$5^{\text {a }}$ coleta: o mesmo que a $2^{\text {a }}$ coleta.

$6^{\text {a }}$ coleta: as misturas M1, M2 e M3 foram estatisticamente iguais entre si. Foram diferentes apenas as misturas M1 e M4.

Os resultados obtidos para carbono orgânico mostram que no segundo preparo a concentração foi aumentando gradativamente ao longo do processo, o que não se pode notar no primeiro preparo, onde os resultados entre as coletas são mais aleatórios. Isso pode estar ligado à forma de preparo diferente entre ambos, sendo o segundo um ambiente mais ideal.

Entre as misturas, o que se pode perceber foi que M3 atingiu o maior valor de COT no final do processo, até mesmo maior do que o valor obtido por todas as misturas no primeiro preparo, chegando a $12000 \mathrm{mg} \mathrm{L}^{-1}$. Em se tratando das outras misturas, nenhuma diferença significativa foi observada.

\subsubsection{Macronutrientes}

Os macronutrientes são de fundamental importância no crescimento vegetativo. Nitrogênio, fósforo e potássio desempenham cada um seu papel nutritivo para o meio vegetal. Segundo a Tabela 1.7, o bagaço de laranja seria o mais pobre em se tratando dos valores médios de macronutrientes.

Tabela 1. 7 - Porcentagem média de matéria orgânica (MO), nitrogênio $(N)$, fósforo $\left(\mathrm{P}_{2} \mathrm{O}_{5}\right)$ e potássio $\left(\mathrm{K}_{2} \mathrm{O}\right)$ na composição, com base na matéria seca de adubos orgânicos.

$$
\begin{array}{lllll}
\text { Adubo orgânico } & \mathrm{MO}(\%) & \mathrm{N}(\%) & \mathrm{P}_{2} \mathrm{O}_{5}(\%) & \mathrm{K}_{2} \mathrm{O}(\%)
\end{array}
$$

\begin{tabular}{ccccc}
\hline Esterco de bovinos & 57 & 1,7 & 0,9 & 1,4 \\
Esterco de equinos & 46 & 1,4 & 0,5 & 1,7 \\
\hline Esterco de suínos & 53 & 1,9 & 0,7 & 0,4 \\
Esterco de ovinos & 65 & 1,4 & 1,0 & 2,0 \\
Esterco de aves & 50 & 3,0 & 3,0 & 2,0 \\
Bagaço de laranja & 31 & 1,4 & 1,4 & 0,8 \\
\hline
\end{tabular}

Fonte: RIBEIRO et al., 1999. 


\section{- Nitrogênio}

Na Figura 1.11 e Tabela 1.8 são mostrados os resultados de nitrogênio na forma NKT em cada coleta ao longo do processo fermentativo.

Figura 1. 11 - Valores de nitrogênio (NKT) em $\mathrm{mg} \mathrm{L}^{-1}$ para os biofertilizantes preparados com resíduo orgânico.
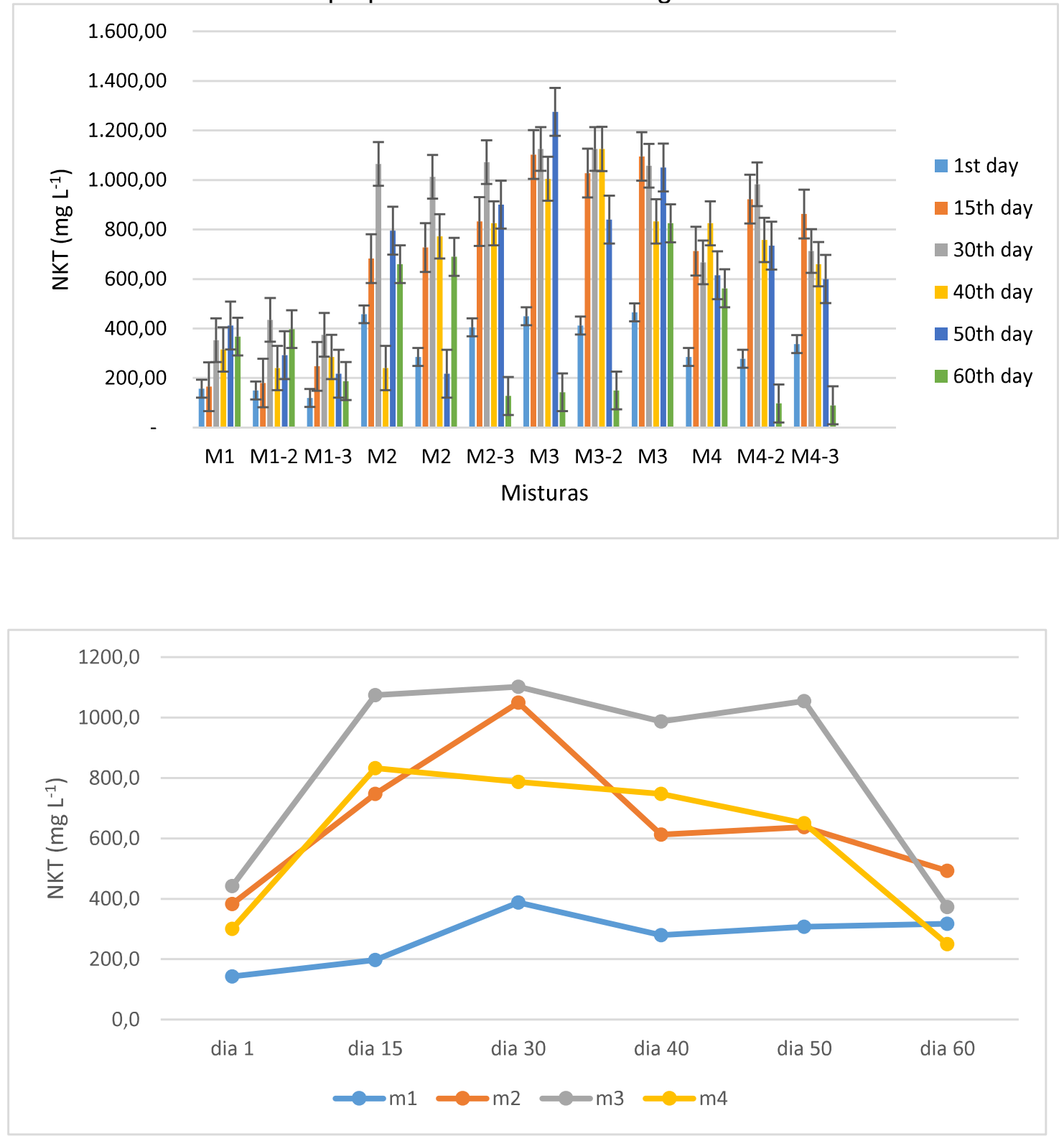

M1 - esterco bovino e bagaço de laranja; M2 - cama de frango e bagaço de laranja; M3 - cama de frango e esterco bovino; M4 - esterco bovino, cama de frango e bagaço de laranja. 
Tabela 1.8 - Valores das médias e dos desvios padrão de cada mistura para valores de nitrogênio na forma de NKT (mg L-1). Médias seguidas pela mesma letra na coluna não diferem significativamente entre si pelo teste de Tukey $(P<0,05)$.

\begin{tabular}{lcccccc}
\hline & $\mathbf{1}^{\mathrm{a}}$ coleta & $\mathbf{2}^{\mathrm{a}}$ coleta & $\mathbf{3}^{\mathrm{a}}$ coleta & $\mathbf{4}^{\mathrm{a}}$ coleta & $\mathbf{5}^{\mathrm{a}}$ coleta & $\mathbf{6}^{\mathrm{a}}$ coleta \\
\hline M1 & $142 \pm 19 \mathrm{a}$ & $197 \pm 43 \mathrm{a}$ & $387 \pm 42 \mathrm{a}$ & $280 \pm 37 \mathrm{a}$ & $307 \pm 98 \mathrm{a}$ & $384 \pm 15 \mathrm{a}$ \\
$\mathbf{M} 2$ & $382 \pm 88 \mathrm{bc}$ & $747 \pm 76 \mathrm{~b}$ & $1050 \pm 32 \mathrm{~b}$ & $779 \pm 42 \mathrm{~b}$ & $804 \pm 91 \mathrm{bc}$ & $659 \pm 31 \mathrm{~b}$ \\
& & & & & & \\
M3 & $442 \pm 27 \mathrm{~b}$ & $1075 \pm 41 \mathrm{c}$ & $1102 \pm 38 \mathrm{~b}$ & $987 \pm 147 \mathrm{~b}$ & $1055 \pm 217 \mathrm{c}$ & $139 \pm 12 \mathrm{c}$ \\
$\mathbf{M 4}$ & $300 \pm 32 \mathrm{c}$ & $832 \pm 108 \mathrm{~b}$ & $787 \pm 170 \mathrm{c}$ & $747 \pm 82 \mathrm{~b}$ & $650 \pm 73 \mathrm{ab}$ & $583 \pm 18 \mathrm{~d}$ \\
\hline
\end{tabular}

$1^{\text {a }}$ coleta: as misturas M2 e M3; M2 e M4; foram estatisticamente iguais, assim, a mistura M1 foi diferente estatisticamente das misturas M2, M3 e M4, assim como, a mistura M3 foi diferente da mistura M4. As misturas M3 e M4 foram diferentes entre si. Em geral, a mistura M1 foi a única diferente.

$2^{\text {a }}$ coleta: as misturas M2 e M4 foram estatisticamente iguais, assim, a mistura M1 foi diferente estatisticamente das misturas M2, M3 e M4, assim como, as mistura M2 e M4 foram diferentes da mistura M3.

$3^{a}$ coleta: apenas as misturas M2 e M3 foram estatisticamente iguais, assim, a mistura M1 foi diferente estatisticamente das misturas M2, M3 e M4.

$4^{\text {a }}$ coleta: as misturas M2, M3 e M4 foram estatisticamente iguais, assim apenas a mistura M1 foi diferente das demais misturas.

$5^{a}$ coleta: as misturas M2 e M3; M1 e M4 foram estatisticamente iguais, assim, a mistura M1 foi diferente de M2 e M3.

$6^{\mathbf{a}}$ coleta: todas as misturas foram estatisticamente diferentes.

Assim como visto na maioria dos outros atributos, mais uma vez a M3 apresentou a maior concentração de nitrogênio em solução (Figura 1.11), seguida de M2 e M4, sendo M1 a mistura com a menor concentração de nitrogênio.

A falta desse nutriente pode causar danos às plantas, pois na fase inicial do crescimento vegetativo pode retardar o crescimento e, consequentemente, a produtividade, além de dar às folhas uma coloração verde pálido.

\section{- Fósforo}

Na Figura 1.12 e Tabela 1.9 descrevem-se os valores de fósforo, os quais se apresentam bastante variados entre as misturas. 
Figura 1. 12 - Valores de fósforo na forma de fosfato em $\mathrm{mg} \mathrm{L}^{-1}$ presentes nos biofertilizantes.
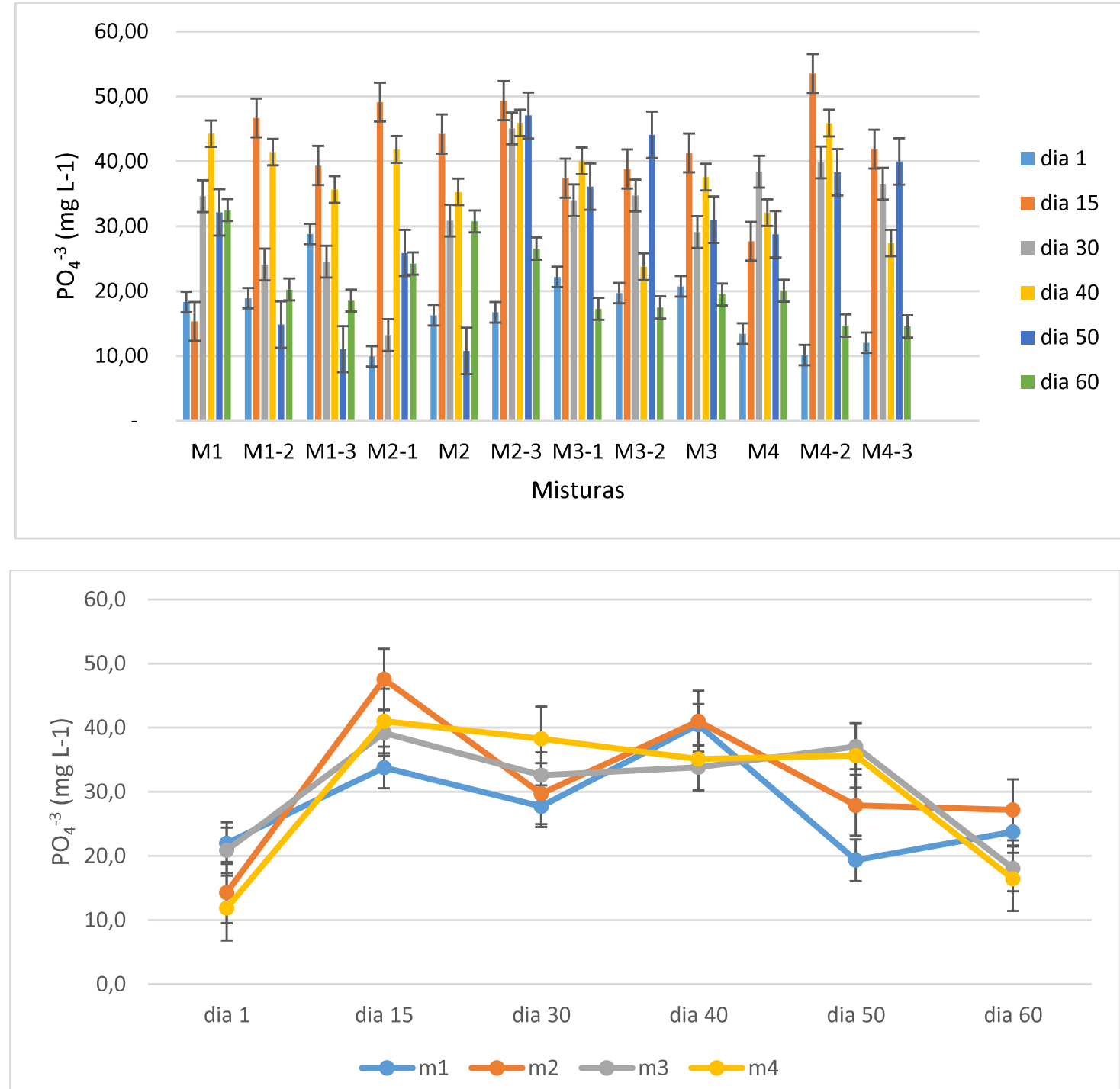

M1 - esterco bovino e bagaço de laranja; M2 - cama de frango e bagaço de laranja; M3 - cama de frango e esterco bovino; M4 - esterco bovino, cama de frango e bagaço de laranja.

Tabela 1. 9 - Valores das médias e dos desvios padrão de cada mistura para valores de fósforo disponível (mg L-1). Médias seguidas pela mesma letra na coluna não diferem significativamente entre si pelo teste de Tukey $(P<0,05)$.

\begin{tabular}{|c|c|c|c|c|c|c|}
\hline & $1^{a}$ coleta & $2^{a}$ coleta & $3^{a}$ coleta & $4^{a}$ coleta & $5^{\mathrm{a}}$ coleta & $6^{\mathrm{a}}$ coleta \\
\hline M1 & $21,99 \pm 5,90 a$ & $33,78 \pm 16,40 a$ & $27,75 \pm 5,94 a$ & $40,44 \pm 4,38 a$ & $19,33 \pm 11,24 a$ & $23,75 \pm 7,61 \mathrm{a}$ \\
\hline M2 & $14,30 \pm 3,80 a b$ & $47,56 \pm 2,90 a$ & $29,71 \pm 15,96 a$ & $41,01 \pm 5,36 a$ & $27,90 \pm 18,22 a$ & $20,49 \pm 12,55 a$ \\
\hline M3 & $20,87 \pm 1,14 a b$ & $39,16 \pm 1,96 a$ & $32,60 \pm 3,08 a$ & $33,80 \pm 8,79 a$ & $37,06 \pm 6,58 a$ & $8,07 \pm 1,21 a$ \\
\hline M4 & $11,87 \pm 1,65 b$ & $41,02 \pm 12,95 a$ & $38,26 \pm 1,64 a$ & $35,12 \pm 9,60 a$ & $35,68 \pm 6,05 a$ & $9,76 \pm 8,91 \mathrm{a}$ \\
\hline
\end{tabular}

$1^{\text {a }}$ coleta: as misturas M1, M2 e M3 foram estatisticamente iguais, e apenas a misturas M1 e M4 foram diferentes.

$2^{\mathrm{a}}, 3^{\mathrm{a}}, 4^{\mathrm{a}}, 5^{\mathrm{a}}$ e $6^{\mathrm{a}}$ coleta: todas as misturas foram estatisticamente iguais. 
O fósforo é responsável pela formação da clorofila e ainda aumenta o desenvolvimento radicular propiciando à planta maior capacidade de absorver os elementos férteis do solo. Age diretamente na qualidade dos frutos e maturação das sementes e sua deficiência pode ser percebida quando as folhas tomam uma coloração arroxeada.

\section{- Potássio}

A Figura 1.13 e Tabela 1.10 mostram os valores de potássio para cada mistura.

Figura 1.13 - Valores de potássio em mg L-1 presentes nos biofertilizantes.
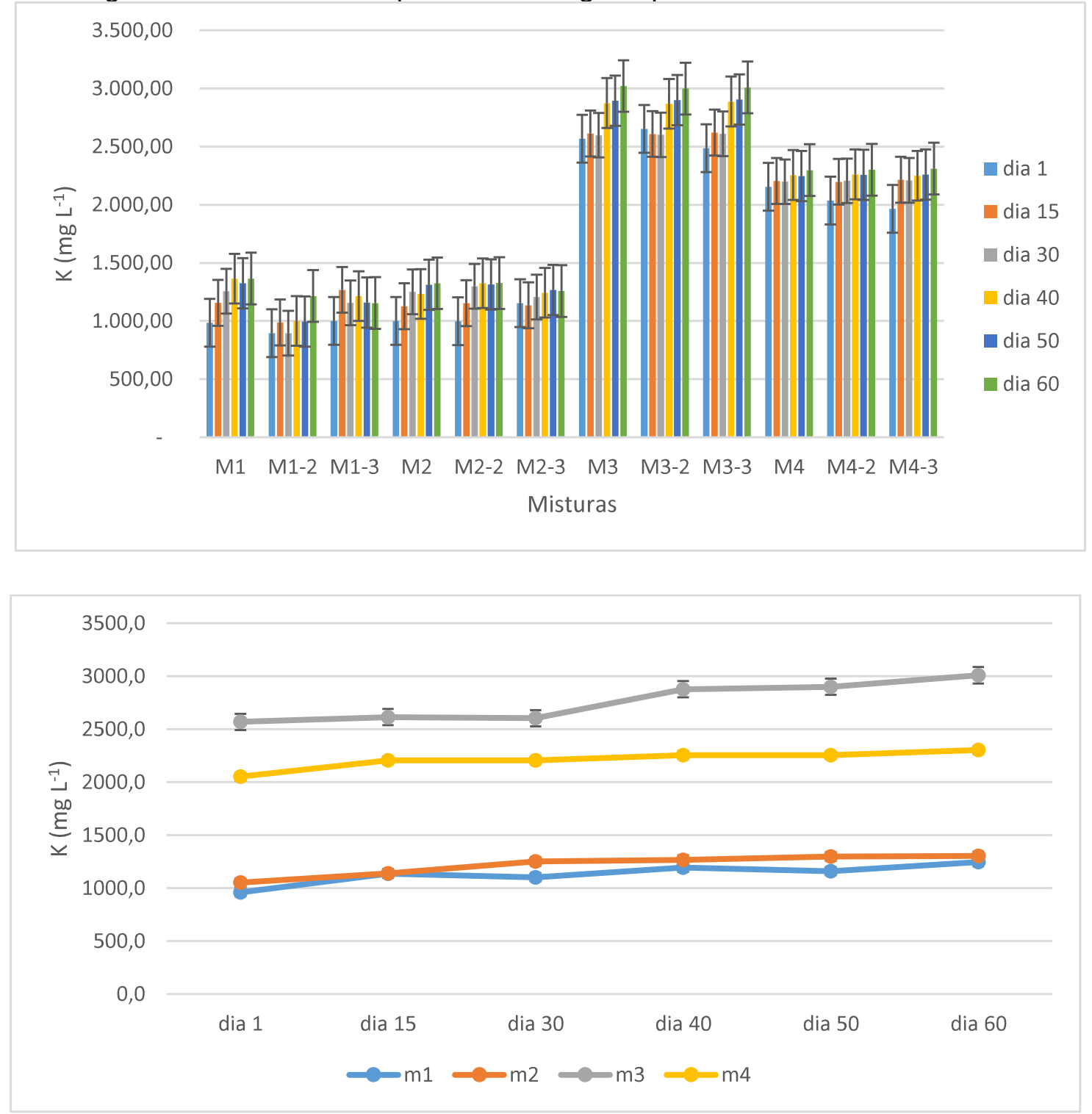

M1 - esterco bovino e bagaço de laranja; M2 - cama de frango e bagaço de laranja; M3 - cama de frango e esterco bovino; M4 - esterco bovino, cama de frango e bagaço de laranja. 
Tabela 1.10 - Valores das médias e dos desvios padrão de cada mistura para valores de potássio disponível $\left(\mathrm{mg} \mathrm{L}^{-1}\right)$. Médias seguidas pela mesma letra na coluna não diferem significativamente entre si pelo teste de Tukey $(\mathrm{P}<0,05)$

\begin{tabular}{|c|c|c|c|c|c|c|}
\hline & $1^{\text {a }}$ coleta & $2^{a}$ coleta & $3^{a}$ coleta & $4^{a}$ coleta & $5^{a}$ coleta & $6^{a}$ coleta \\
\hline M1 & $960 \pm 55 a$ & $1137 \pm 141 a$ & $1102 \pm 185 a$ & $1193 \pm 183 a$ & $1160 \pm 165$ & $1244 \pm 108 a$ \\
\hline M2 & $1051 \pm 89 a$ & $1138 \pm 14 a$ & $1251 \pm 45 a$ & $1267 \pm 50 a$ & $1298 \pm 26$ & $1303 \pm 39 a$ \\
\hline M3 & $2569 \pm 82 b$ & $2614 \pm 6 b$ & $2603 \pm 6 b$ & $2877 \pm 9 a$ & $2901 \pm 4$ & $3009 \pm 11 b$ \\
\hline M4 & $2051 \pm 95$ c & $2205 \pm 8 c$ & $2205 \pm 6$ c & $2255 \pm 5 a$ & $2255 \pm 7$ & $2303 \pm 6 c$ \\
\hline
\end{tabular}

1a coleta: as misturas M1 e M2; M3 e M4 foram estatisticamente iguais, assim, a mistura M1 foi diferente estatisticamente das misturas M3 e M4, assim como, a mistura M2 foi diferente de M3 e M4. As misturas M3 e M4 foram diferentes entre si. $2^{\mathrm{a}}$ coleta: o mesmo que a $1^{\mathrm{a}}$ coleta.

$3^{a}$ coleta: o mesmo que a $1^{\text {a }}$ coleta.

$4^{\text {a }}$ coleta: todas as misturas foram estatisticamente iguais.

$5^{\text {a }}$ coleta: não foi possível fazer a ANOVA, pois os dados não apresentam uma distribuição normal (pelo teste de normalidade da ANOVA).

$6^{\mathrm{a}}$ coleta: o mesmo que a $1^{\mathrm{a}}$ coleta.

O que pode-se observar é que diferente de nitrogênio e fósforo, o potássio não sofreu variações ao longo das coletas. Como nos outros atributos analisados, as misturas M1 e M2 possuem as menores concentrações de potássio, enquanto que a mistura M3 apresentou as maiores concentrações, perto de $3 \mathrm{~g} \mathrm{~L}^{-1}$.

Vale lembrar que a oscilação entre os valores de NKT, fosfato e potássio presentes nas Figuras 1.11, 1.12 e 1.13, anteriormente mostradas, é devido ao fato que nenhuma situação foi forçada, embora tudo tenha sido feito em ambiente protegido, todo o preparo foi em escala real, havendo interferências externas.

\subsubsection{Nutrientes}

$\mathrm{Na}$ Figura 1.14 pode-se observar o comportamento de cada nutriente em função da mistura. 
Figura 1. 14 - Comportamento dos nutrientes comparando cada mistura.

Cálcio

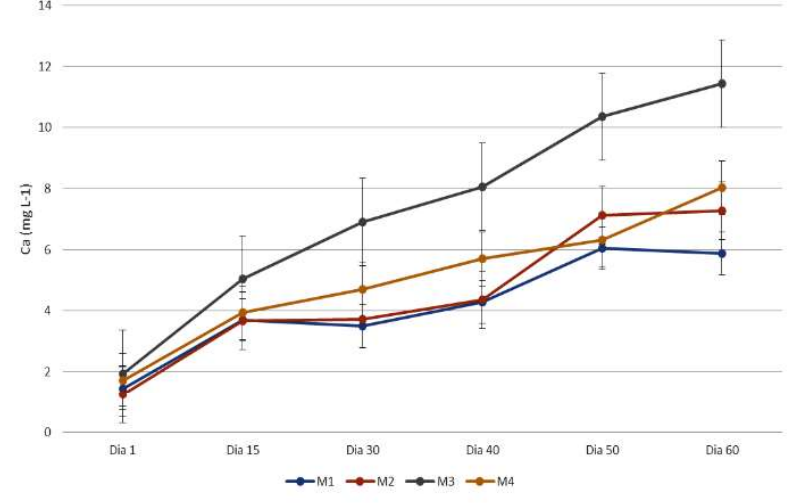

Cobre

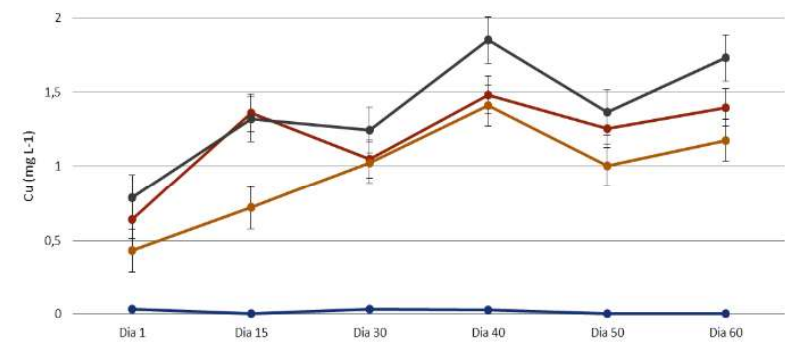

$\rightarrow \mathrm{M} 1 \rightarrow \mathrm{M} 2 \rightarrow \mathrm{M} 3 \rightarrow-M 4$

Manganês

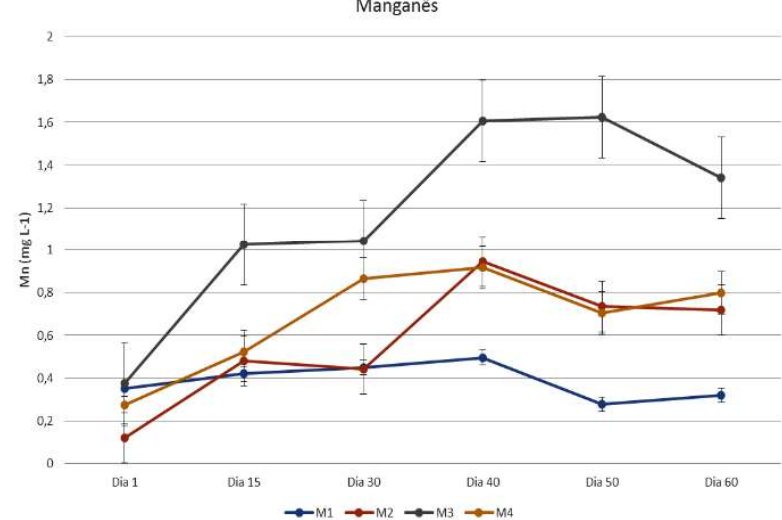

magnésio

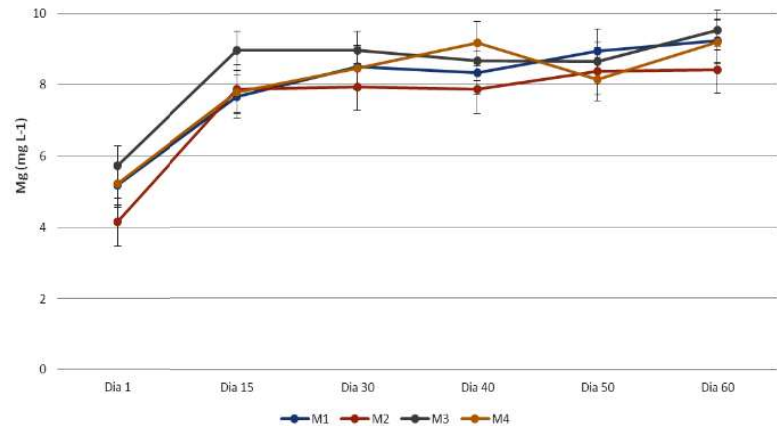

Ferro

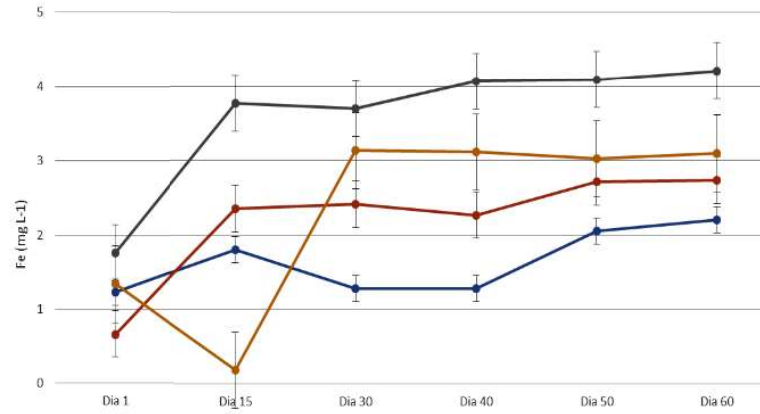

$\rightarrow \mathrm{M}_{1} \rightarrow \mathrm{M}_{2} \rightarrow \mathrm{M}_{3} \rightarrow \mathrm{M}_{4}$

Zinco

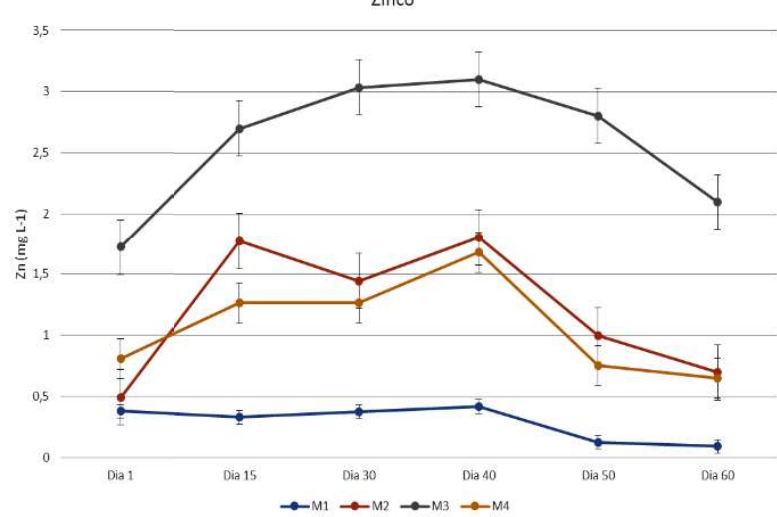

M1 - esterco bovino e bagaço de laranja; M2 - cama de frango e bagaço de laranja; M3 - cama de frango e esterco bovino; M4 - esterco bovino, cama de frango e bagaço de laranja.

Todas as misturas tiveram aumento na disponibilidade desses ao longo do processo fermentativo. Isso é muito bom para o caráter nutritivo dos biofertilizantes, mostrando que a fermentação ajuda na liberação dos nutrientes tornando-os disponíveis.

Com os resultados obtidos na Figura 1.14, pode-se observar que para todos os nutrientes, exceto o ferro, a M3 apresenta a maior disponibilidade nutricional no final 
do processo, mostrando que a M3 apresenta uma tendência a ser mais nutritiva em relação às outras, o que poderá ser confirmado ao final da aplicação das misturas nas culturas de alface. Dentre as bases trocáveis, o cálcio e magnésio, em todas as misturas foram os nutrientes mais encontrados. Isso é fator positivo para o caráter nutricional dos biofertilizantes, pois os dois são nutrientes indispensáveis para o crescimento das plantas, com grande contribuição para a CTC.

Diferentemente, o manganês e o zinco não apresentam resultados significantes nas misturas, ou seja, não seguem uma tendência, como observado nos outros nutrientes, isso pode ser devido à interferência dos outros elementos, fazendo com que sejam deslocados para que outras espécies iônicas ocupem o sítio ativo.

\subsubsection{Urease}

Teores de urease são de fundamental importância, uma vez que a planta pode utilizar essa ureia como fonte de nitrogênio.

Figura 1.15 - Valores de urease nos biofertilizantes preparados a partir de resíduos orgânicos.

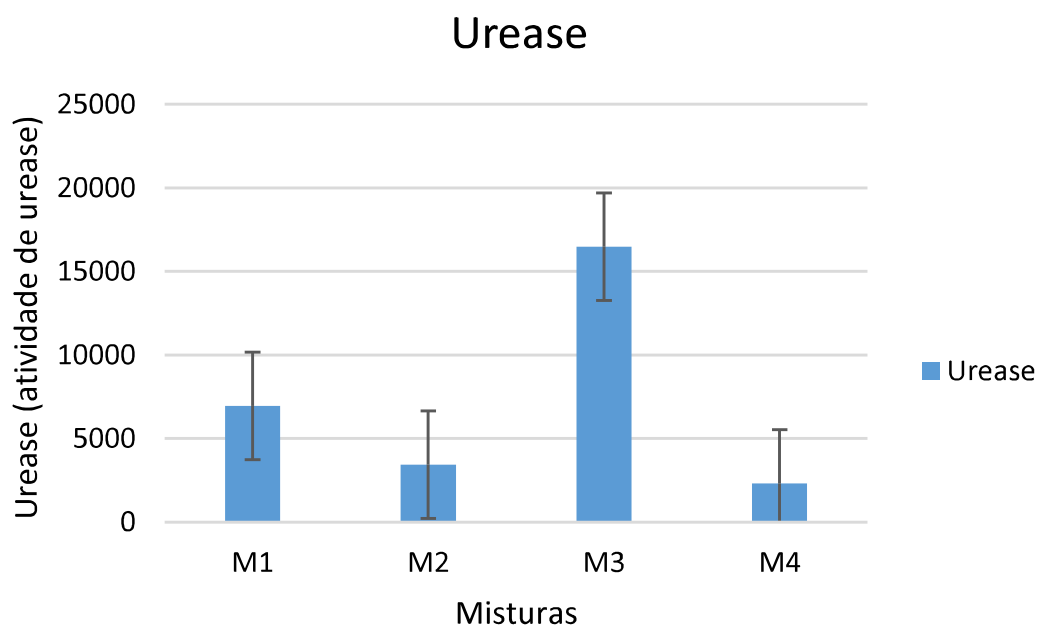

M1 - esterco bovino e bagaço de laranja; M2 - cama de frango e bagaço de laranja; M3 - cama de frango e esterco bovino; M4 - esterco bovino, cama de frango e bagaço de laranja.

Ensaio de urease é usado para predizer a libertação de nitrogênio a partir de resíduos orgânicos, quando adicionados ao solo. A atividade de urease foi maior em M3. Esta é uma indicação do desaparecimento de amônio, que pode atuar como inibidor. Os biofertilizantes M1 e M3 tiveram a maior atividade de urease, sugerindo que o esterco bovino favoreça a atividade da urease com a degradação do estrume de gado dando origem à formação de substrato $N$ susceptível de utilização por 
enzimas (ROS et al., 2006). No entanto, a atividade da urease baixa em M4 indica que o biofertilizante é mais estável do que os outros, pois uma baixa atividade da urease indica a estabilidade do composto (DELGADO et al., 2004). Isso indica que o uso combinado de casca de laranja, esterco bovino e cama de frango aumentaram a taxa de produção de biofertilizante.

\subsection{Conclusões}

O que se pode dizer é que em todas as misturas os atributos analisados estão de acordo com o Ministério da Agricultura, Pecuária e Abastecimento, sendo que este só exige a especificação das propriedades em caso de produto comercial.

Com os resultados discutidos, pode-se dizer que os biofertilizantes previamente preparados podem ser um excelente fertilizante orgânico, substituindo os adubos organominerais convencionais que algumas vezes causam danos ao meio ambiente além dos custos envolvidos.

As etapas seguintes são a avaliação da aplicação dessas misturas em alface hidropônica. Desde já, pode-se esperar que esta eficiência agronômica seja alcançada na cultura de alface hidropônica. 

Capítulo II

Caracterização espectroscópica por Infravermelho com Transformada de Fourier (FTIR) dos biofertilizantes e de seus ácidos húmicos 



\section{RESUMO DO CAPITULO II}

MENDES, Leandro Antunes. Capítulo II - Caracterização espectroscópica por Infravermelho com Transformada de Fourier (FTIR) dos biofertilizantes e de seus ácidos húmicos. Tese (Doutorado em Química). Universidade de São Paulo, Instituto de Química de São Carlos, 2017. p. 43-54.

A avaliação das substâncias húmicas $(\mathrm{SH})$, quanto à quantidade de ácidos húmicos $(A H)$ e fúlvicos $(A F)$ e sua qualidade permite inferir sobre o grau de estabilidade e maturidade da matéria orgânica presente nos produtos finais. Os métodos espectroscópicos e analíticos fornecem informações valiosas no estudo da dinâmica da matéria orgânica e seus constituintes húmicos. Entre outras técnicas, a espectroscopia de Infravermelho com Transformada de Fourier (FTIR) permite identificar os grupos reacionais e componentes estruturais nas substâncias húmicas, e desta forma pode-se inferir sobre o grau de maturação, de estabilidade do material húmico. Quando se comparam os espectros do AH extraídos, notamos bandas com maior intensidade para a M3, mostrando ser essa a mistura em que a humificação da matéria orgânica se mostrou mais presente, sendo esse um indicativo de que essa mistura apresenta melhores resultados agronômicos em relação às outras. A diferença entre os espectros dos biofertilizantes e dos ácidos húmicos extraídos desses biofertilizantes está basicamente nos valores de absorbância, sendo as bandas características as mesmas para os dois. Lembrando que para M3 e M4 os espectros dos AH tiveram maiores valores de absorbância do que do biofertilizante correspondente, enquanto que M1 e M2 apresentaram o contrário, ou seja, os valores de absorbância dos biofertilizantes M1 e M2 foram maiores do que os valores obtidos quando se extrai e purifica o ácido húmico. 



\subsection{Materiais e métodos}

\subsubsection{Extração e purificação dos ácidos húmicos}

No fracionamento químico para obtenção das substâncias húmicas, as amostras dos biofertilizantes M1, M2, M3 e M4 foram submetidas a um processo de extração por diferença de solubilidade e purificação, segundo a metodologia recomendada para solos pela Sociedade Internacional de Substâncias Húmicas (SWIFT, 1989).

Substâncias húmicas são produtos da intensa transformação dos resíduos orgânicos e polimerização dos compostos orgânicos (principalmente através de reações de condensação, metilação e oxidação) até macromoléculas resistentes à degradação biológica (SANTOS \& CAMARGO, 1999 e CANELLAS et al., 2001).

Partindo de 100,0 g de biofertilizante, inicialmente foi realizada uma extração com HCl 0,1 mol L-1 em proporção de 1,0 g de biofertilizante para 10,0 mL de solução. Durante uma hora a solução permaneceu sob agitação manual, ocasionalmente. Em seguida foi deixada em repouso por duas horas, para separar o sobrenadante do precipitado por decantação, sendo este sobrenadante o primeiro extrato de ácido fúlvico. Em seguida, ao sobrenadante foi adicionada solução de $\mathrm{NaOH} 0,1 \mathrm{~mol} \mathrm{~L}^{-1}$, na mesma proporção anteriormente citada. A solução permaneceu sob agitação manual durante quatro horas, ocasionalmente. A mistura foi mantida em repouso durante dezesseis horas, para separar o sobrenadante do resíduo por decantação. O precipitado é referente à fração mineral (humina), a qual foi descartada. O sobrenadante foi centrifugado, por vinte minutos a 10000 rpm, para a separação da argila. Em seguida, com um conta-gotas, o sobrenadante foi acidificado com $\mathrm{HCl} 6$ mol L-1 até $\mathrm{pH}$ entre 1 e 2, sob agitação constante e foi deixado em repouso por mais doze horas, para decantação. O precipitado é referente à fração de ácido húmico e o sobrenadante é o extrato 2 do ácido fúlvico, que foi separado por sifonação. A partir dessa etapa teve início a purificação dos ácidos húmicos, o precipitado foi redissolvido em solução de $\mathrm{KOH} 0,1 \mathrm{~mol} \mathrm{~L}^{-1}$ e the foi adicionado $\mathrm{KCl}$ para completar uma concentração de íons $\mathrm{K}^{+}$equivalente a $0,3 \mathrm{~mol} \mathrm{~L}^{-1}$. A solução foi centrifugada para a eliminação dos sólidos suspensos (impurezas). Após a centrifugação sob alta velocidade, 15000 rpm por 20 min para que os sólidos suspensos fossem decantados e, assim, removidos, o $\mathrm{AH}$ foi então reprecipitado, adicionando-se $\mathrm{HCl} 6,0 \mathrm{~mol} \mathrm{~L}^{-1} \mathrm{com}$ agitação simultânea até que fosse atingido o pH entre 1 e 2 e, após, a suspensão foi 
mantida em repouso por 16 horas. Centrifugou-se a solução (10000 rpm por 10 min) e o sobrenadante foi então descartado. O precipitado $(A H)$ foi suspenso em solução $\mathrm{HCl}$ 0,1 mol L-1 $+\mathrm{HF}$ 0,3 mol L-1 em um recipiente plástico e agitado durante 16 horas a temperatura ambiente. Em seguida a solução foi centrifugada (12000 rpm por 20 min) e o precipitado foi transferido para uma membrana de diálise (Spectra/Por 6000 - 8000 Da), preparada segundo a metodologia de Mc Phie (1971), utilizando água destilada, padrão MiliQ. Procedeu-se à diálise até que a água de diálise apresentasse teste negativo de $\mathrm{Cl}^{-}$após a adição de solução de nitrato de prata. Para isso, tal procedimento foi mantido durante aproximadamente sete dias, fazendo-se a troca da água, diariamente. Após a diálise, as amostras foram congeladas com nitrogênio líquido e liofilizadas. Após a liofilização os $\mathrm{AH}$ foram macerados e armazenados para as caracterizações.

A extração e purificação dos ácidos húmicos foram feitas a fim de analisar e comparar os espectros de FTIR dos biofertilizantes assim como dos AH extraídos.

\subsubsection{Análise de FTIR}

As análises de FTIR foram feitas seguindo a metodologia sugerida por STEVENSON (1994). As pastilhas foram preparadas na proporção de $1,0 \mathrm{mg}$ de amostra de ácido húmico e do biofertilizante liofilizado para 100,0 mg de $\mathrm{KBr}$ (seco em estufa a $105^{\circ} \mathrm{C}$ ). As pastilhas foram prensadas por 2 minutos com uma carga equivalente a 10 toneladas. Os espectros foram obtidos a partir de 32 varreduras no intervalo de 4000 a $400 \mathrm{~cm}^{-1}$ com resolução espectral de $4 \mathrm{~cm}^{-1}$. O equipamento utilizado foi o espectrômetro de FTIR da Bombem MB-102, pertencente à CAQI IQSC - USP.

\subsection{Resultados e discussão}

Os espectros de infravermelho apresentaram bandas típicas de ácidos húmicos (Figura 2.1 e Figura 2.2). As bandas foram atribuídas de acordo com publicações de STEVENSON (1994), MANGRICH et al. (2000), AMALFITANO et al. (2002), CASTOLDI et al. (2005), SILVERSTEIN et al. (2010) e FIALHO et al. (2010).

Inicialmente foi feita uma análise comparativa dos espectros dos biofertilizantes liofilizados comparando as misturas entre si, assim como do ácido húmico extraído dos biofertilizantes. 
Como mostrado na Figura 2.1, quando se comparam os espectros dos biofertilizantes liofilizados pode-se perceber que os picos acontecem nos mesmos números de onda para todas as misturas, sendo que algumas vezes estes picos são mais intensos.

Figura 2.1 - Espectros de FTIR de cada mistura de biofertilizante.

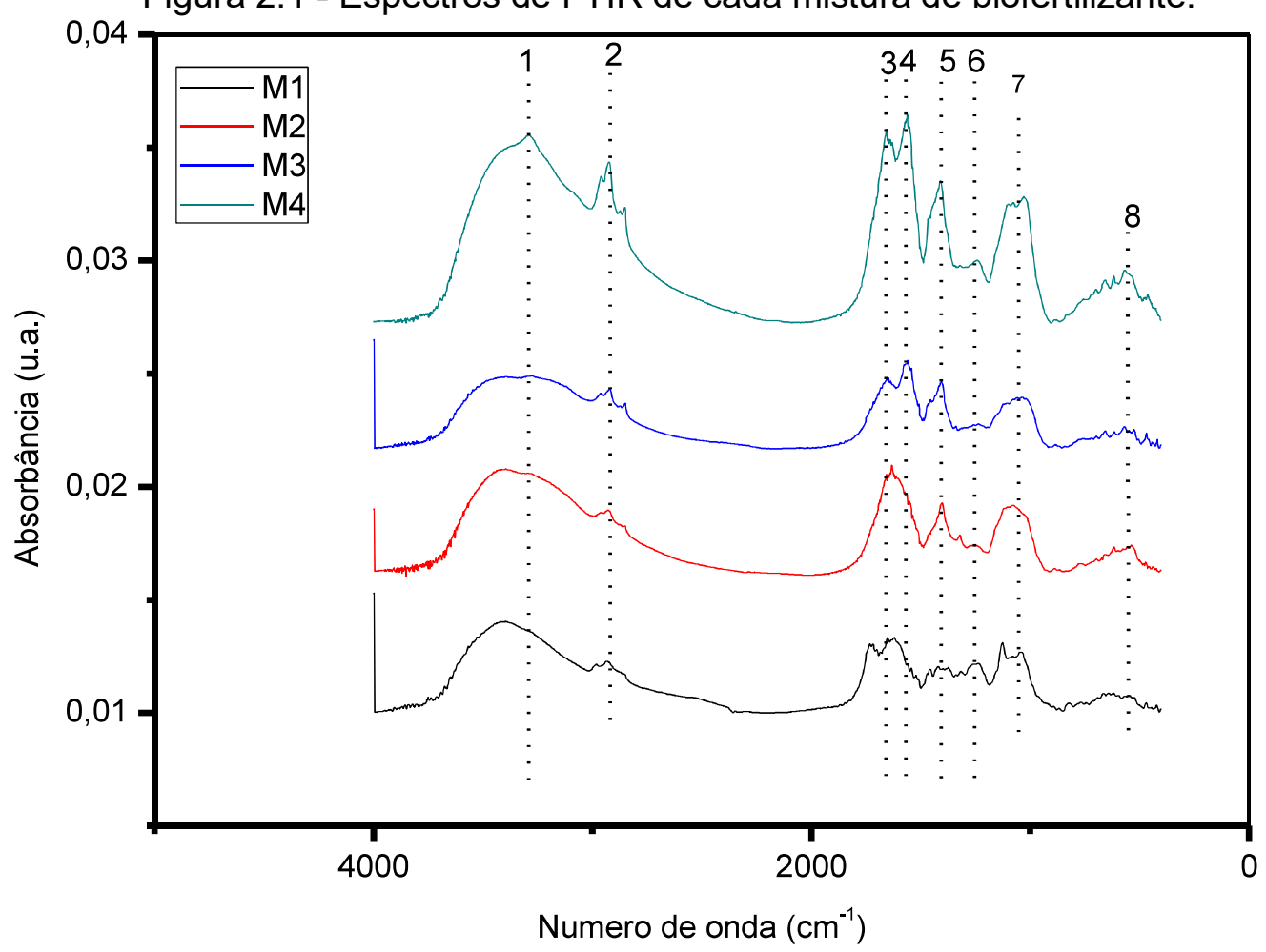

Na Figura 2.1, os espectros apresentam bandas características iguais em todas regiões, sendo que no caso da M4, essas bandas mostraram-se mais largas e intensas. Isso pode ser devido à complexidade da mistura, uma vez que a M4 foi preparada com os 3 resíduos: bagaço de laranja, esterco bovino e cama de frango.

As bandas características determinadas para os biofertilizantes e ácidos húmicos extraídos estão mostradas na Tabela 2.1 .

Todos as misturas apresentaram bandas em torno de $3400-3300 \mathrm{~cm}^{-1}$ que corresponde a banda de estiramento $\mathrm{O}-\mathrm{H}$ de grupos fenólicos ou $\mathrm{N}-\mathrm{H}$ de amidas. CASTALDI et al. (2005) mostraram em seus estudos uma diminuição dessa banda referente ao desaparecimento de grupo $\mathrm{O}-\mathrm{H}$ devido ao amadurecimento da matéria orgânica. No presente estudo, a M3 apresentou a menor banda nessa região (3400$3300 \mathrm{~cm}^{-1}$ ), mostrando-se como uma tendência dessa mistura ter uma matéria orgânica mais ativa, bem humificada capaz de tornar os nutrientes mais disponíveis para as alfaces em relação as outras misturas. 
Tabela 2. 1 - Bandas características dos espectros dos biofertilizantes e dos ácidos húmicos extraídos desses biofertilizantes.

\begin{tabular}{|c|c|c|}
\hline & Bandas $\left(\mathrm{cm}^{-1}\right)$ & Atribuição \\
\hline 1 & 3296,8 & $\begin{array}{c}\text { Estiramento de } \mathrm{OH} \text { fenólico (contribuição der } \mathrm{OH} \\
\text { alifático), } \mathrm{H}_{2} \mathrm{O} \text { e possivelmente } \mathrm{NH}\end{array}$ \\
\hline 2 & 2922,0 & Estiramento $\mathrm{CH}$ assimétrico \\
\hline 3 & 1654,0 & $\begin{array}{c}\text { Estiramento } \mathrm{C}=\mathrm{C} \text { aromático e/ou estiramento }-\mathrm{COO}^{-} \\
\text {assimétrico }\end{array}$ \\
\hline 4 & 1560,0 & $\begin{array}{c}\text { Estiramento } \mathrm{C}=\mathrm{C} \text { aromático, deformação } \mathrm{N}-\mathrm{H} \text { e } \\
\text { estiramento } \mathrm{C}=\mathrm{N} \text { de amidas }\end{array}$ \\
\hline 5 & 1410,0 & Deformação $-\mathrm{CH}$ de $\mathrm{CH}_{3}$ e dobramento $-\mathrm{CH}$ e $-\mathrm{CH}_{2}$ \\
\hline 6 & 1238,0 & Estiramento -C-O de deformação $\mathrm{OH}$ de $-\mathrm{COOH}$ \\
\hline 7 & 1028,0 & $\begin{array}{l}\text { Estiramento -C-O de polissacarídeos e Si-O de } \\
\text { impurezas silicatadas }\end{array}$ \\
\hline 8 & 569,0 & Vibração $\mathrm{CH}$ fora do plano \\
\hline
\end{tabular}

Duas bandas distintas estão presentes em torno de $2900 \mathrm{~cm}^{-1}$, as quais são referentes a estiramento $\mathrm{C}-\mathrm{H}$ de estruturas alifáticas nos espectros dos biofertilizantes de todas as misturas. Mais uma vez essa banda foi mais evidente para a M4, isso pode ser devido à complexidade da mistura, uma vez que M4 foi feita com os três resíduos usados neste trabalho. Um fato evidente também nesse caso é que para M1, M2 e M3 essa banda foi menos intensa, mostrando uma diminuição de grupamentos alifáticos que são mais facilmente decompostos, mostrando assim, uma transformação da matéria orgânica, em um produto húmico mais estável. Já para M4, onde essa banda foi intensa, subentende-se que a mistura ainda se encontrava em um processo de decomposição, podendo-se assim dizer que ainda não estava humificada.

Para todas as misturas, pode-se observar um ombro nos espectros por volta de $1700-1500 \mathrm{~cm}^{-1}$ referente a grupamentos carbonílicos $(C=O)$ não conjugados e em torno de $1650 \mathrm{~cm}^{-1}$ uma banda referente a $\mathrm{C}=\mathrm{O}$ conjugados, $\mathrm{C}=\mathrm{C}$ em estruturas aromáticas, deformação $\mathrm{N}-\mathrm{H}$ de amidas primárias ou ainda estiramento assimétrico $\mathrm{C}-\mathrm{O}$ de íons carboxilatos $\mathrm{COO}^{-}$, sendo mais uma vez essa banda mais evidente para a M4.

Bandas de absorção na faixa de 1560 e $1410 \mathrm{~cm}^{-1}$ estão presentes nos espectros de todas as misturas e são referentes a estiramento de anéis aromáticos de monômeros de lignina (FIALHO et al. 2010). 
Na Figura 2.2 estão os espectros dos ácidos húmicos extraídos de cada biofertilizante. $\mathrm{O}$ que se pode perceber é que os espectros dos ácidos húmicos são praticamente iguais aos espectros dos biofertilizantes correspondentes, sendo a única diferença entre os espectros dos $\mathrm{AH}$ e dos biofertilizantes alguns ruídos que são eliminados na extração e purificação dos ácidos húmicos.

Figura 2. 2 - Espectros de FTIR de cada mistura dos AH extraídos dos biofertilizantes.

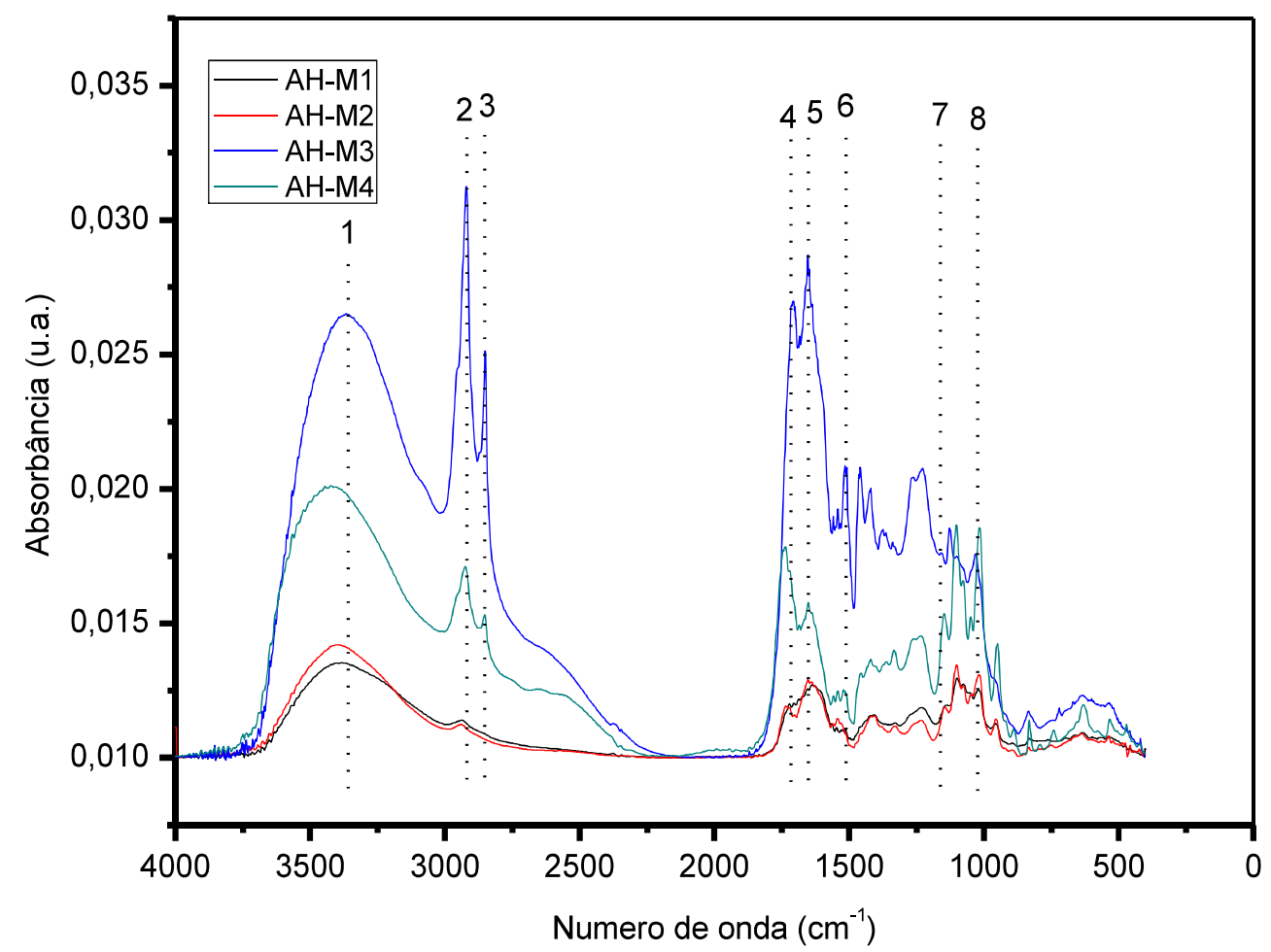

Como pode-se observar, os espectros dos ácidos húmicos se assemelham com os espectros dos seus biofertilizantes, apresentando as mesmas características. Uma diferença entre eles é que para os espectros dos biofertilizantes, a M4 foi a mistura que apresentou as bandas mais intensas em relação às outras misturas. Já para os espectros dos ácidos húmicos, a M3 foi a mistura em que as bandas foram mais intensas.

Quando se comparam os espectros dos biofertilizantes com seus respectivos espectros dos ácidos húmicos uma informação importante é que para M1 e M2 o espectro do biofertilizante é mais intenso do que o espectro do ácido húmico, apresentando valores de absorbância maiores. Já em relação a M3 e M4 esse comportamento é invertido, ou seja, o espectro do ácido húmico apresenta valores de absorbância maiores do que o espectro do biofertilizante correspondente. Isso evidencia um ácido húmico mais humificado para M3 e M4 em relação a M1 e M2, 
sendo uma característica relevante, uma vez que estas misturas (M3 e M4) apresentaram os melhores potenciais agronômicos no cultivo das alfaces. A Figura 2.3 mostra os espectros dos biofertilizantes sendo comparados com seus respectivos espectros de ácido húmico.

Figura 2.3 - Espectros de infravermelho de cada mistura de biofertilizante comparada com o
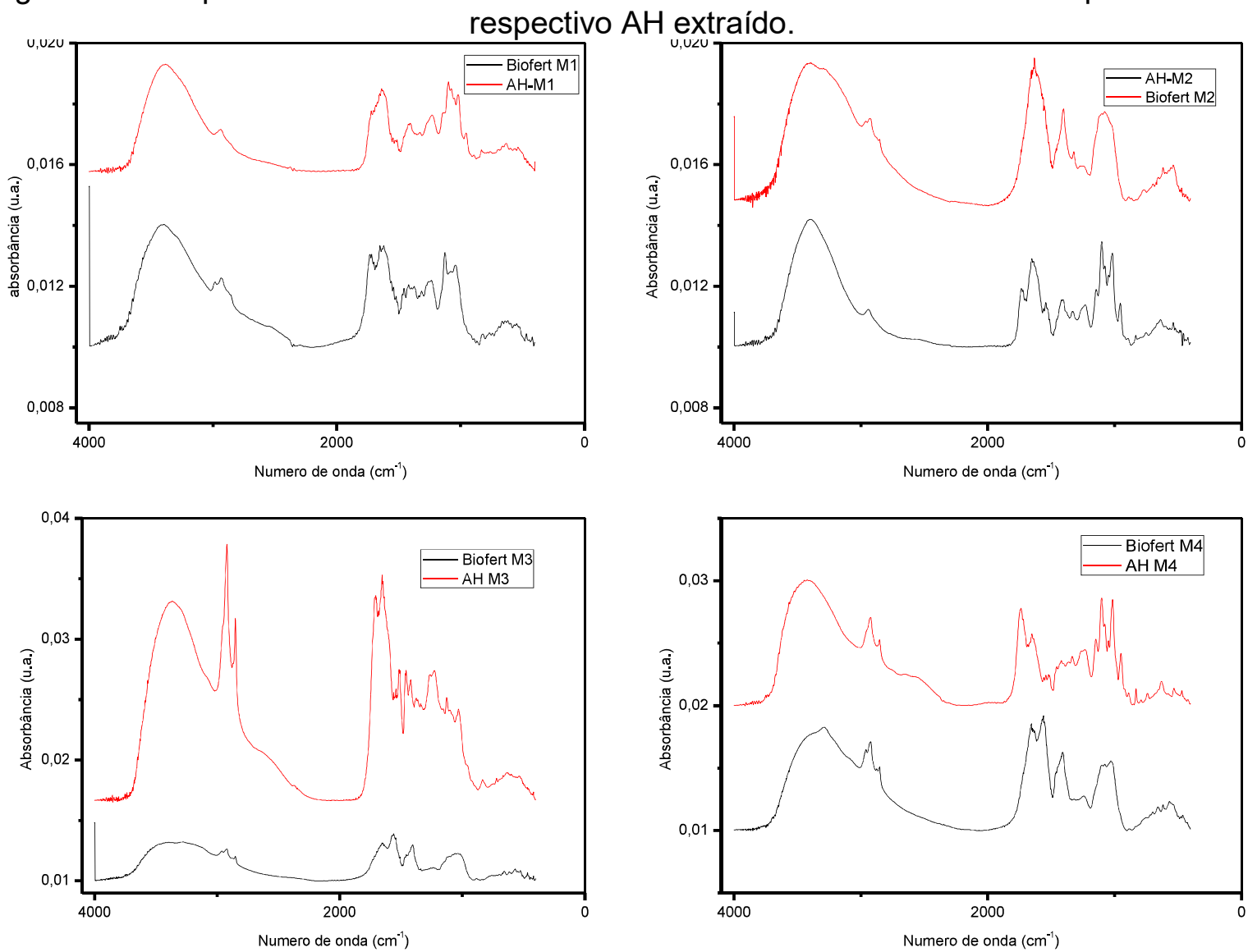

A diferença entre os espectros dos biofertilizantes e dos ácidos húmicos extraídos dos mesmos está basicamente nos valores de absorbância, sendo as bandas características as mesmas para os dois. Lembrando que para M3 e M4 os espectros dos $\mathrm{AH}$ tiveram maiores valores de absorbância do que do biofertilizante, enquanto que M1 e M2 apresentaram o contrário, ou seja, os valores de absorbância dos biofertilizantes M1 e M2 foram maiores do que os valores obtidos quando se extrai e purifica o ácido húmico.

\subsection{Conclusões}

A análise das características estruturais revelou diferenças entre os ácidos húmicos estudados. Os espectros de FTIR dos ácidos húmicos de todas as misturas 
apresentaram bandas típicas de substâncias húmicas, indicando transformações moleculares como a perda de estruturas mais lábeis devido ao processo de biodegradação. Também foram observados grupos $\mathrm{OH}, \mathrm{COOH}, \mathrm{COO}, \mathrm{CO}_{2} \mathrm{NH}_{2}$, que confirmam a presença de sistemas aromáticos. A similaridade dos espectros de FTIR sugere que a lignina foi extraída junto com os ácidos húmicos.

Além disso, pode-se concluir que os espectros determinados para os biofertilizantes assim como para os ácidos húmicos extraídos não se diferenciam muito entre si. Quando se comparam os espectros de FTIR dos biofertilizantes, podese perceber que os mesmos não se diferenciam muito em relação aos espectros de AH padrão encontrado na literatura para solos, sendo presente apenas alguns ruídos referentes a impurezas no material.

Quando se comparam os espectros do $\mathrm{AH}$ extraídos, nota-se bandas com maior intensidade para $\mathrm{M} 3$, mostrando ser essa a mistura em que a humificação da matéria orgânica se mostrou mais presente, sendo esse um indicativo de que essa mistura apresenta melhores resultados agronômicos em relação às outras.

A diferença entre os espectros dos biofertilizantes e dos ácidos húmicos extraídos desses biofertilizantes está basicamente nos valores de absorbância, sendo as bandas características as mesmas para os dois. Lembrando que para M3 e M4 os espectros dos AH tiveram maiores valores de absorbância do que do biofertilizante correspondente, enquanto que M1 e M2 apresentaram o contrário, ou seja, os valores de absorbância dos biofertilizantes M1 e M2 foram maiores do que os valores obtidos quando se extrai e purifica o ácido húmico. 
Capítulo III

Análises bioquímicas dos biofertilizantes

(Fenóis, carboidratos e aminoácidos) 



\section{RESUMO DO CAPITULO III}

MENDES, Leandro Antunes. Capítulo III - Análises bioquímicas dos biofertilizantes (Fenol, carboidratos e aminoácidos). In: Avaliação das transformações químicas e do potencial agronômico de biofertilizantes líquidos produzidos a partir de resíduos agroindustriais para o manejo sustentável em agricultura orgânica. Tese (Doutorado em Química). Universidade de São Paulo, Instituto de Química de São Carlos, 2017. p. 55-66.

Neste capítulo estão descritas as análises bioquímicas desenvolvidas no Laboratório Nacional de Agricultura e Meio Ambiente (USDA-ARS), localizado na cidade de Ames, lowa, sob a co-orientação do Dr. Dan Olk, onde o aluno desenvolveu novos métodos de extrações da fração orgânica assim como a caracterização bioquímica dos biofertilizantes no tocante a aminoácidos, carboidratos e fenóis. Este trabalho foi de suma importância uma vez que o laboratório Nacional de Agricultura e Meio Ambiente onde o pesquisador Dr. Dan Olk desenvolve seus trabalhos tem grande experiência na área em questão, podendo contribuir para a formação acadêmica do aluno. Com esses resultados pode-se observar que o bagaço de laranja tem papel importante na presença desses carboidratos. Esse fato é comprovado pois nas misturas em que se tem o resíduo de laranja na composição foram encontradas as maiores concentrações de carboidratos. Com isso, pode-se dizer que os carboidratos são oriundos do bagaço de laranja, esse fato já era esperado devido à grande concentração de açucares presentes em laranjas, o que contribui para os maiores valores em questão. Os maiores valores para todas as misturas foram para a glucose, sendo esse o carboidrato em maior quantidade no bagaço de laranja, tendo sua origem na celulose presente nos resíduos vegetais. Em relação aos resultados dos aminoácidos e aminoaçucares, todas as misturas apresentaram em sua maioria aminoácidos em suas composições. Com isso, pode-se perceber uma tendência dessas misturas serem bastantes férteis devido à presença desses compostos que são de fundamental importância em todos os ciclos vegetais. Os fenóis são compostos que ajudam na estabilização do nitrogênio do solo. As misturas M1 e M3 apresentam uma tendência de ter mais fenóis em sua composição em relação às outras. Com esses resultados pode-se predizer que o esterco bovino é um material rico em lignina, que foi o fenol mais encontrado nas amostras de biofertilizantes em questão. A M3 foi a mistura em que se encontrou o maior teor de fenóis, isso já era esperado pois esse barril foi preparado com esterco bovino e cama de frango, ambos os resíduos apresentam bastantes fenóis em sua composição oriundos dos vegetais que são usados na matéria-prima para obtenção desses resíduos. 



\subsection{Materiais e métodos}

\subsubsection{Carboidratos}

Monossacarídeos a partir da celulose e hemicelulose foram extraídos e analisados como descrito por MARTENS e FRANKENBERGER (1990) e MARTENS e LOEFFELMANN (2002). Resumidamente, $800 \mu \mathrm{L}$ de $\mathrm{H}_{2} \mathrm{SO}_{4} 6 \mathrm{~mol} \mathrm{~L}^{-1}$ foram adicionados a $100 \mathrm{mg}$ do biofertilizante em tubos de cultura de vidro. Após a mistura, a solução foi deixada em repouso durante 30 minutos à temperatura ambiente, em seguida diluída para $1 \mathrm{~mol} \mathrm{~L}^{-1}$ de $\mathrm{H}_{2} \mathrm{SO}_{4}$. Esta solução foi submetida à autoclavagem durante 30 minutos a $121^{\circ} \mathrm{C}$, em seguida, centrifugada e o sobrenadante removido com lavagem quantitativa do resíduo restante com água destilada. Este resíduo foi guardado e processado como celulose (ácido forte extraído de carboidratos) tal como descrito abaixo. O sobrenadante contendo as hemiceluloses (hidratos de carbono leve extraíveis) teve seu pH ajustado para 5,5-6,5, com solução diluída de $\mathrm{NaOH}$, e uma alíquota foi injetada em um cromatógrafo Dionex de ânion (Sunnyvale, CA), DX-500 equipado com uma PA-10 coluna CarboPac (2 mm de diâmetro x $250 \mathrm{~mm}$ de comprimento). Todos os hidratos de carbono foram detectados via amperometria pulsada tripla (JOHNSON et al, 1993; OLK, 2008). A extração da celulose foi realizada no resíduo seco com solução de $\mathrm{H}_{2} \mathrm{SO}_{4} 1,5 \mathrm{~mol} \mathrm{~L}^{-1}$, seguida de repouso durante 30 min. (CREAMER et al., 2012).

\subsubsection{Aminoácidos e amino-açúcares}

A extração e análise de aminoácidos e amino-açúcares foram idênticas ao processo descrito por CREAMER et al. (submetido) e por MARTENS e LOEFFELMANN (2002) e modificado por OLK et al. (2008). Resumidamente, o ácido metanossulfônico $4 \mathrm{~mol} \mathrm{~L}^{-1}$ contendo 0,2 \% (em massa) de triptamina [3-(2-aminoetil) indol] foi adicionado a $250 \mathrm{mg}$ do material e autoclavado a $136^{\circ} \mathrm{C}$ e $248 \mathrm{kPa}$ de pressão durante 90 minutos. Após o preparo, as alíquotas foram injetadas em um cromatógrafo de ânion Dionex (Sunnyvale, CA), DX - 500 equipado com uma PA - 10 coluna Dionex AminoPac e detectado com amperometria pulsada tripla (JOHNSON et al, 1993; OLK, 2008). Com este método, asparagina e glutamina são convertidas ao ácido glutâmico e ácido aspártico, respectivamente, e a cisteína é convertida a cistina (CREAMER et al., 2012). 


\subsubsection{Fenóis}

As concentrações de fenóis derivados da lignina foram determinadas por meio de uma oxidação com $\mathrm{CuO}$ por procedimento modificado de HEDGES e MANN (1979). As amostras foram colocadas em bombas de pressão em conjunto com $\mathrm{NaOH}$ e CuO. As misturas foram purgadas com gás de Ar, seladas, e aquecidas durante $3 \mathrm{~h}$ a $150^{\circ} \mathrm{C}$. Os fenóis foram extraídos da solução por meio de lavagens repetidas com éter e centrifugações, em seguida, filtradas e derivatizadas através de sililação com bis-(trimetilsilil)-trifluoroacetamida. As amostras foram analisadas por cromatografia em fase gasosa para as respectivas concentrações de ácido ferúlico e ácido phidroxicumárico (juntos chamados ácidos cinâmicos), e aldeído, cetona, e formas ácidas de siringil, vanílico e fenois p-hidroxibenzóico (OLK et al., 2009).

\subsection{Resultados e discussão}

\subsubsection{Carboidratos}

Os carboidratos serviram para ajudar no entendimento da composição das misturas como mostrado na Tabela 3.1 abaixo.

Tabela 3.1 - Média e respectivos desvios-padrão dos valores dos carboidratos encontrados

\begin{tabular}{ccccc}
\multicolumn{5}{c}{ nas misturas (M1, M2, M3 e M4), em $\mu g$ g-1. } \\
\hline Carbo & M1 & M2 & M3 & M4 \\
& & & & \\
\hline Fucose & $385 \pm 12$ & $308 \pm 11$ & $116 \pm 14$ & $134 \pm 15$ \\
Arabinose & $966 \pm 16$ & $1414 \pm 9$ & $823 \pm 14$ & $674 \pm 14$ \\
Rhamnose & $1436 \pm 20$ & $1123 \pm 8$ & $433 \pm 9$ & $659 \pm 9$ \\
Galactose & $1038 \pm 12$ & $1318 \pm 7$ & $583 \pm 7$ & $851 \pm 13$ \\
& & & & \\
W.A.Glucose & $2424 \pm 13$ & $1836 \pm 4$ & $671 \pm 12$ & $1268 \pm 8$ \\
S.A.Glucose & $1185 \pm 17$ & $1249 \pm 14$ & $198 \pm 11$ & $39 \pm 14$ \\
Xilose & $609 \pm 14$ & $612 \pm 9$ & $835 \pm 10$ & $270 \pm 11$ \\
Manose & $753 \pm 14$ & $313 \pm 13$ & n.a. & $167 \pm 11$
\end{tabular}

M1 - esterco bovino e bagaço de laranja; M2 - cama de frango e bagaço de laranja; M3 - cama de frango e esterco bovino; M4 - esterco bovino, cama de frango e bagaço de laranja. 
Com esses resultados pode-se observar que o bagaço de laranja tem papel importante na presença desses açucares. Esse fato é comprovado pois nas misturas em que se tem o resíduo de laranja na composição foram encontrados as maiores concentrações de carboidratos. Com isso, pode-se dizer que os carboidratos são oriundos do bagaço de laranja, esse fato já era esperado devido à grande concentração de açucares presentes em laranjas, o que contribui para os maiores valores em questão.

Esse fato pode ser comprovado pelo carboidrato manose, pois na mistura em que não se encontra bagaço de laranja (M3), esse composto não foi encontrado, com esse resultado pode-se dizer que a manose é exclusivamente oriunda do bagaço.

Existe uma exceção no carboidrato xilose, pois esse teve sua concentração maior na M3, a qual não se encontra o resíduo de laranja, logo, esse composto podese dizer que tem origem nos materiais vegetais presentes no esterco bovino e/ou cama de frango.

Os maiores valores para todas as misturas foram para a glucose, sendo esse o carboidrato que tem em maior quantidade no bagaço de laranja, tendo sua origem na celulose presente nos resíduos vegetais.

\subsubsection{Aminoácidos e amino-açúcares}

A determinação de aminoácidos é importante pois o processo de fermentação anaeróbio gera aminoácidos devido a hidrólise de várias proteínas. Os aminoácidos são benéficos para as plantas durante todo o ciclo (ALVES, 2009), participando de diferentes processos fisiológicos e bioquímicos, tais como: a síntese de proteínas; a formação de fito-hormônios; a regulação do balanço hídrico nas plantas, e como moléculas quelantes de íons necessários à nutrição das plantas, entre outras funções.

A Tabela 3.2 mostra os resultados de cada aminoácido para os biofertilizantes produzidos de todas as misturas. 
Tabela 3. 2 - Média e respectivos desvios-padrão dos valores de cada aminoácido encontrado nas misturas (M1, M2, M3 e M4), em $\mu g^{-1}$.

\begin{tabular}{|c|c|c|c|c|}
\hline Aminoácido & M1 & M2 & M3 & M4 \\
\hline Arginina & $11.693 \pm 437$ & $21.228 \pm 315$ & $9.551 \pm 160$ & $8.100 \pm 76$ \\
\hline Ornitina & $1.338 \pm 422$ & $602 \pm 194$ & $2.091 \pm 112$ & $2.062 \pm 130$ \\
\hline Lisina & $2.907 \pm 111$ & $3.268 \pm 864$ & $3.417 \pm 124$ & $11.043 \pm 253$ \\
\hline Galactosamina & $39.883 \pm 561$ & $50.535 \pm 870$ & $53.260 \pm 702$ & $47.879 \pm 755$ \\
\hline Glucosamina & $104.795 \pm 7$ & $123.907 \pm 137$ & $117.078 \pm 159$ & $120.350 \pm 755$ \\
\hline Alanina & $4.346 \pm 287$ & $8147 \pm 50$ & $132.285 \pm 241$ & $15.182 \pm 124$ \\
\hline Treonina & $2.830 \pm 359$ & $3903 \pm 78$ & $5.647 \pm 239$ & $5.829 \pm 351$ \\
\hline Glicina & $2.636 \pm 108$ & $4.523 \pm 14$ & $7.797 \pm 526$ & $7.799 \pm 614$ \\
\hline Valina & $2.931 \pm 185$ & $4.774 \pm 23$ & $9.094 \pm 552$ & $9.842 \pm 511$ \\
\hline Hidroxiprolina & $356 \pm 19$ & $394 \pm 21$ & $288 \pm 52$ & $197 \pm 87$ \\
\hline Serina & $2.104 \pm 318$ & $2.561 \pm 247$ & $4.641 \pm 143$ & $5.022 \pm 156$ \\
\hline Prolina & $2.685 \pm 144$ & $3.207 \pm 41$ & $6.289 \pm 352$ & $6.111 \pm 414$ \\
\hline Isoleucina & $4.276 \pm 969$ & $4.662 \pm 58$ & $8.155 \pm 307$ & $8.674 \pm 626$ \\
\hline Leucina & $4.800 \pm 356$ & $7.312 \pm 81$ & $11.990 \pm 745$ & $13.431 \pm 106$ \\
\hline Metionina & $737 \pm 186$ & $900 \pm 15$ & $1.588 \pm 111$ & $1.885 \pm 178$ \\
\hline Histidina & $123 \pm 64$ & $195 \pm 21$ & $360 \pm 204$ & $367 \pm 252$ \\
\hline Fenilalanina & $805 \pm 9$ & $1.197 \pm 13$ & $1.322 \pm 471$ & $1.149 \pm 820$ \\
\hline Ac. Glutâmico & $6.970 \pm 890$ & $8.295 \pm 71$ & $8.091 \pm 596$ & $9.231 \pm 200$ \\
\hline Ac. Aspártico & $5.599 \pm 785$ & $5.758 \pm 25$ & $6.368 \pm 546$ & $7.682 \pm 238$ \\
\hline Cistina & --- & --- & --- & --- \\
\hline Tirosina & --- & --- & --- & --- \\
\hline
\end{tabular}

M1 - esterco bovino e bagaço de laranja; M2 - cama de frango e bagaço de laranja; M3 - cama de frango e esterco bovino; M4 - esterco bovino, cama de frango e bagaço de laranja. 
Como pode-se observar, para alguns aminoácidos os valores desvio padrão estão bastante elevados, isso pode ser devido ao fato de que nas análises usa-se uma quantidade de amostra bastante pequena $(10 \mathrm{mg}$ ) podendo aumentar a margem de erro, além da complexidade das misturas que podem também acarretar nesses erros.

Os aminoácidos são sintetizados pelas plantas a partir do $\mathrm{N}$ inorgânico absorvido da solução do solo, de ácidos orgânicos, requerendo uma quantidade considerável de energia pela planta. Quando se fornecem aminoácidos livres para uma planta, ela os absorve diretamente e faz uso imediato deles. Isto é muito importante porque nas fases de floração, frutificação, maturação, associado aos estresses, sejam eles, falta de água, calor, transplante, a planta fica livre do trabalho de sintetizar os aminoácidos.

Em relação aos resultados, todas as misturas apresentaram em sua maioria aminoácidos em suas composições. Com isso, pode-se perceber uma tendência dessas misturas serem bastantes férteis devido à presença desses compostos, pois, como dito anteriormente, os aminoácidos são de fundamental importância em todos os ciclos vegetais.

Entre as misturas, pode-se notar que a M4 apresenta a maior quantidade para quase todos os aminoácidos, mostrando uma leve tendência em essa mistura ser mais fértil em relação às outras, quando se fala somente em relação aos aminoácidos, sendo ainda cedo para conclusões a respeito da fertilidade dos biofertilizantes. Em contrapartida, a M1 foi a menos favorecida em relação aos aminoácidos, sendo esta a que apresentou os menores valores para esses compostos.

O fato de M4 ser a mais enriquecida em relação aos aminoácidos pode ser devido ao fato de essa mistura ser composta dos três resíduos em questão (bagaço de laranja, cama de frango e esterco bovino), sendo uma forma melhor de obter esses compostos em solução devido a maior variedade de resíduos.

\subsubsection{Fenóis}

Essa análise nos mostra a composição dos biofertilizantes (Tabela 3.3). Os fenóis são compostos que ajudam na estabilização do nitrogênio do solo. 
Tabela 3.3 - Média e respectivos desvios-padrão dos valores de cada fenol encontrado nas misturas (M1, M2, M3 e M4), em $\mu \mathrm{g}$ g-1.

\begin{tabular}{ccccc}
\hline Fenóis & $\mathbf{M 1}$ & $\mathbf{M 2}$ & $\mathbf{M 3}$ & $\mathbf{M 4}$ \\
\hline p-hidroxibenzaldeído & $1,05 \pm 0,06$ & $0,77 \pm 0,02$ & $1,42 \pm 0,32$ & $0,36 \pm 0,02$ \\
p-hidroxiacetofenona & $0,27 \pm 0,03$ & $0,07 \pm 0,00$ & $0,94 \pm 0,34$ & $0,04 \pm 0,01$ \\
Vanilina & $1,16 \pm 0,03$ & $0,61 \pm 0,02$ & $1,36 \pm 0,46$ & $0,75 \pm 0,03$ \\
Acetovanilina & $0,79 \pm 0,01$ & $0,32 \pm 0,01$ & $0,21 \pm 0,14$ & $0,22 \pm 0,01$ \\
Ácido p-hidroxibenzóico & $0,31 \pm 0,01$ & $0,29 \pm 0,01$ & $0,44 \pm 0,04$ & $0,22 \pm 0,01$ \\
Siringaldeído & $1,11 \pm 0,04$ & $0,39 \pm 0,01$ & $1,78 \pm 0,40$ & $0,95 \pm 0,03$ \\
Ácido vanílico & $0,50 \pm 0,01$ & $0,38 \pm 0,01$ & $2,19 \pm 0,89$ & $0,26 \pm 0,01$ \\
Acetosiringona & $2,30 \pm 0,02$ & $2,27 \pm 0,05$ & $1,56 \pm 0,73$ & $0,82 \pm 0,02$ \\
& & & & \\
Ácido siríngico & $0,32 \pm 0,01$ & $0,17 \pm 0,01$ & $2,01 \pm 0,28$ & $0,27 \pm 0,01$ \\
Ácido p-hidroxicumárico & $0,89 \pm 0,04$ & $0,19 \pm 0,02$ & $0,97 \pm 0,23$ & $0,51 \pm 0,02$
\end{tabular}

Ácido ferúlico $\quad 1,49 \pm 0,02 \quad 1,08 \pm 0,08 \quad 1,35 \pm 0,08 \quad 0,03 \pm 0,00$

M1 - esterco bovino e bagaço de laranja; M2 - cama de frango e bagaço de laranja; M3 - cama de frango e esterco bovino; M4 - esterco bovino, cama de frango e bagaço de laranja.

Como pode-se observar, as misturas M1 e M3 apresentam uma tendência de ter mais fenóis em sua composição em relação às outras. Com esses resultados podese predizer que o esterco bovino é um material rico em lignina, que foi o fenol mais encontrado nas amostras de biofertilizantes em questão. O M3 foi a mistura onde se encontrou o maior teor de fenóis, isso já era esperado pois esse barril foi preparado com esterco bovino e cama de frango, ambos resíduos apresentam bastantes fenóis em sua composição oriundos dos vegetais que são usados na matéria-prima para obtenção desses resíduos.

A Tabela 3.4 nos mostra alguns fatores relacionados com os fenóis encontrados nos biofertilizantes. 
Tabela 3.4 - Média e respectivos desvios-padrão dos valores das variáveis calculadas a partir dos resultados de fenóis em cada mistura (M1, M2, M3 e M4), em $\mu \mathrm{g} \mathrm{g}^{-1}$.

\begin{tabular}{ccccc}
\hline & M1 & M2 & M3 & M4 \\
\hline Total P & $0,32 \pm 0,02$ & $0,22 \pm 0,01$ & $0,40 \pm 0,04$ & $0,12 \pm 0,01$ \\
Total V & $0,48 \pm 0,01$ & $0,26 \pm 0,01$ & $0,58 \pm 0,09$ & $0,24 \pm 0,01$ \\
Total C & $0,47 \pm 0,01$ & $0,25 \pm 0,02$ & $0,46 \pm 0,07$ & $0,21 \pm 0,01$ \\
Total S & $0,73 \pm 0,01$ & $0,56 \pm 0,01$ & $0,89 \pm 0,08$ & $0,40 \pm 0,01$ \\
\hline Ad/AI V & $0,43 \pm 0,01$ & $0,62 \pm 0,02$ & $0,76 \pm 0,01$ & $0,34 \pm 0,02$ \\
\hline Ad/AI S & $0,29 \pm 0,00$ & $0,43 \pm 0,02$ & $0,67 \pm 0,80$ & $0,28 \pm 0,01$ \\
\hline Lambda 8 & $1,68 \pm 0,03$ & $1,06 \pm 0,03$ & $1,93 \pm 1,04$ & $0,85 \pm 0,03$ \\
Lambda 6 & $1,21 \pm 0,02$ & $0,81 \pm 0,02$ & $1,47 \pm 0,27$ & $0,64 \pm 0,02$
\end{tabular}

M1 - esterco bovino e bagaço de laranja; M2 - cama de frango e bagaço de laranja; M3 - cama de frango e esterco bovino; M4 - esterco bovino, cama de frango e bagaço de laranja.

Total P é a soma das ligninas com orientação para, ou seja, o somatório de ( $p$ hidroxibenzaldeído + p-hidroxiacetofenona). Esses fenóis além de ter origem da lignina podem também surgir de microrganismos presentes no meio. Total $\vee$ é o total de fenóis vanilina, que é um aldeído fenólico também encontrado nas amostras (vanilina + acetovanilina + ácido vanílico). Total C é o total de ácido p-hidroxicumárico + ácido ferúlico que são fenóis longos fáceis de serem quebrados, e por último o Total $S$ é a soma dos fenóis siringicos como acetosiringona + ácido siríngico.

Todas essas somas são feitas para agrupar os fenóis que apresentam as mesmas características e assim facilitar o entendimento do comportamento do material em questão. Com exceção dos fenóis agrupados com $\mathrm{P}$, todos os outros são oriundos da lignina.

Fazendo a relação dos ácidos pelos aldeídos (Ad/AIV e Ad/AIS), que é a relação de ácido vanílico por acetovanillona e ácido siríngico por acetossiringona, respectivamente, pode-se ver a tendência de oxidação da amostra. Nas amostras em questão a ordem crescente de oxidação tanto para $S$ quanto para $V$ foi $\mathrm{M} 4<\mathrm{M} 1<\mathrm{M} 2<\mathrm{M} 3$. Mais uma vez o M3 se mostrou a mistura em que houve melhor a oxidação dos ácidos a aldeído. 
Os fatores lambda 8 e lambda 6 nada mais são também que a soma dos fenóis encontrados. O lambda 8 engloba os oito compostos fenólicos denominados como $V+C+S$ e o lambda $6, V+S$. A única diferença é que os fenóis $V$ e $S$ são mais difíceis de serem fragmentados.

\subsection{Conclusões}

Conclui-se com as análises bioquímicas desenvolvidas na USDA que em relação aos carboidratos o bagaço de laranja tem papel importante na presença desses açucares. Esse fato é comprovado pois nas misturas em que se tem o resíduo de laranja na composição foram encontrados as maiores concentrações de carboidratos. Com isso, pode-se dizer que os carboidratos são oriundos do bagaço de laranja, esse fato já era esperado devido à grande concentração de açucares presentes em laranjas, o que contribui para os maiores valores em questão.

Entre as misturas, pode-se notar que a M4 apresenta a maior quantidade para quase todos os aminoácidos, mostrando uma leve tendência em essa mistura ser mais fértil em relação às outras, quando se fala somente em relação aos aminoácidos. Em contrapartida, a M1 foi a menos favorecida em relação aos aminoácidos, sendo esta a que apresentou os menores números para esses compostos.

As misturas M1 e M3 apresentam uma tendência de ter mais fenóis em sua composição em relação às outras. Com esses resultados pode-se predizer que o esterco bovino é um material rico em lignina, que foi o fenol mais encontrado nas amostras de biofertilizantes em questão. O M3 foi a mistura onde se encontrou o maior teor de fenóis, isso já era esperado pois esse barril foi preparado com esterco bovino e cama de frango, ambos resíduos apresentam bastantes fenóis em sua composição oriundos dos vegetais que são usados na matéria-prima para obtenção desses resíduos.

Os resultados obtidos no exterior foram de grande valia para o projeto, uma vez que com essas caracterizações pode-se predizer de onde estão surgindo os nutrientes capazes de melhorar o potencial agronômico dos biofertilizantes. 
Capítulo IV

\section{Aplicação dos biofertilizantes em cultivo de alface hidropônica}





\section{RESUMO DO CAPITULO IV}

MENDES, Leandro Antunes. Capítulo IV - Aplicação dos biofertilizantes em cultivo de alface hidropônica. In: Avaliação das transformações químicas e do potencial agronômico de biofertilizantes líquidos produzidos a partir de resíduos agroindustriais para o manejo sustentável em agricultura orgânica. Tese (Doutorado em Química). Universidade de São Paulo, Instituto de Química de São Carlos, 2017. p. 67-94.

Neste capítulo estão descritos os procedimentos feitos com os biofertilizantes após o preparo e caracterização de cada mistura. Foram aplicados os biofertilizantes mantendo sempre a condutividade elétrica na faixa de $2.500 \mu \mathrm{S} \mathrm{cm}^{-1}$, além do monitoramento da temperatura e da pressão durante os 30 dias. Foi possível perceber que a M3 (cama de frango + esterco bovino) foi a mistura que menos sofreu variação dos atributos de monitoramento. Durante os 30 dias de crescimento das alfaces o sistema hidropônico foi acompanhado minuciosamente a fim de evitar o entupimento do sistema e consequentemente a perda do experimento. Após os 30 dias de crescimento, as alfaces foram coletadas e analisadas biometricamente quanto: massa fresca da parte aérea (MFPA), circunferência da cabeça, número de folhas, massa seca da parte aérea (MSPA), comprimento da folha e altura do pé. Com os resultados dessas análises pode-se perceber que para todos os atributos a ordem de resposta agronômica crescente foi: M3>M4>M1>M2 (M1 - esterco bovino e bagaço de laranja; M2 - cama de frango e bagaço de laranja; M3 - cama de frango e esterco bovino; M4 - esterco bovino, cama de frango e bagaço de laranja). Além disso, foi feita a análise microbiológica nas alfaces quanto a coliformes totais e coliformes termotolerantes e os resultados foram satisfatórios, ou seja, apenas nas alfaces onde se aplicou a M2 foram identificados coliformes termotolerantes sendo estas não aptas para consumo. Vale lembrar que as análises foram feitas sem nenhuma higienização das alfaces, podendo este resultado ser diminuído ou até mesmo não encontrado após a correta higienização. Em suma, pode-se concluir que a M3 além de apresentar os melhores resultados da caracterização dos biofertilizantes, esta mistura mostrou-se também como a melhor a ser aplicada nas alfaces hidropônicas. 



\subsection{Materiais e métodos}

4.1.1. Montagem dos perfis hidropônicos na casa de vegetação

A casa de vegetação foi construída nas dependências do Campus II da Universidade de São Paulo, São Carlos-SP, sendo um ambiente protegido.

Foram construídas três bancadas de hidroponia com $2 \%$ de inclinação para facilitar o escoamento da solução nutritiva. Uma foi utilizada como berçário, tendo as dimensões dos furos menores que a utilizada para os outros dois perfis utilizados para o crescimento das alfaces para evitar o escoamento das mudas até atingirem tamanho ideal. As dimensões exatas e tamanho estrão mostradas na Figura 4.1. Tendo o berçário 196 furos, enquanto que nos perfis de crescimento das alfaces havia 92 furos por bancada.

Figura 4.1 - Esquema ilustrativo das bancadas hidropônicas e suas respectivas dimensões.

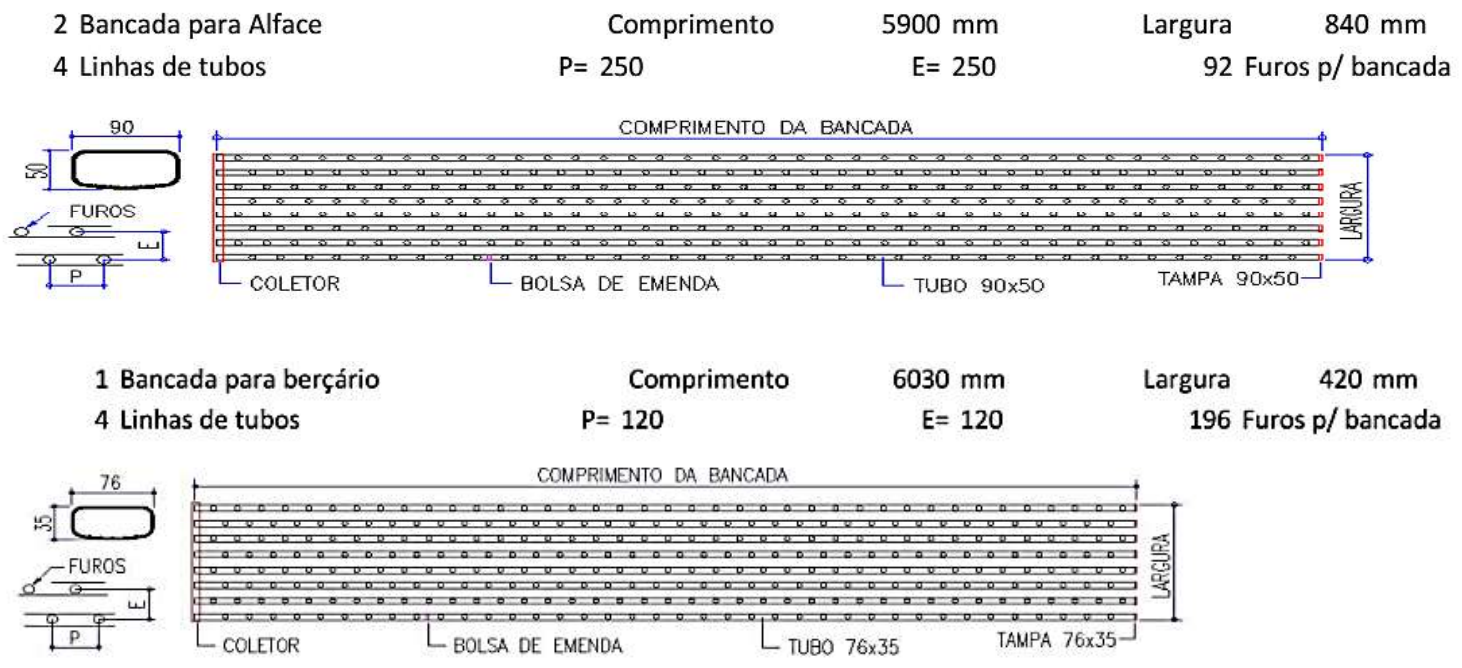

Cada bancada estava interligada a uma caixa d'água de 250 litros, onde foi colocada a solução nutritiva previamente preparada (Figura 4.2). Foi feito todo um esquema de registros a fim de controlar a vazão em qualquer ponto necessário do perfil hidropônico. Além disso, o esquema contava com o auxílio de timeres, onde o tempo de escoamento foi controlado durante todo o crescimento das culturas, trabalhando das $06 \mathrm{~h}$ às $18 \mathrm{~h}$ com intervalos de 15 minutos, e das $18 \mathrm{~h}$ às $06 \mathrm{~h}$ intervalos de 30 minutos, durante 24 horas por 30 dias. A vazão da solução era controlada visualmente para que permitisse a absorção dos nutrientes necessários, não sendo nem tão rápida, nem tão lenta. 
Figura 4. 2 - Montagem dos perfis hidropônicos: 1) limpeza da área onde foram montados os perfis; 2) caixas para solução nutritiva sendo colocadas no chão; 3) montagem dos tubos dos perfis; 4) esquema dos tubos interligando as caixas com os perfis; 5) aterramento dos tubos de retorno; 6) disposição das caixas já com a parte elétrica das bombas.
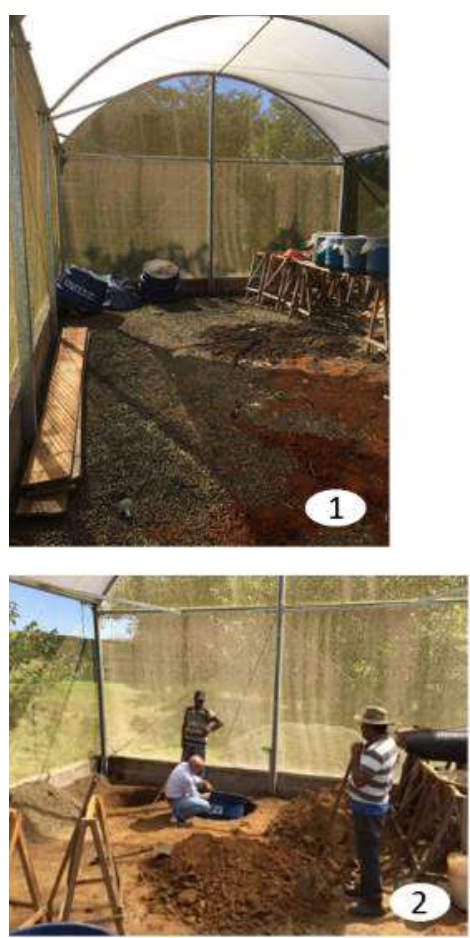
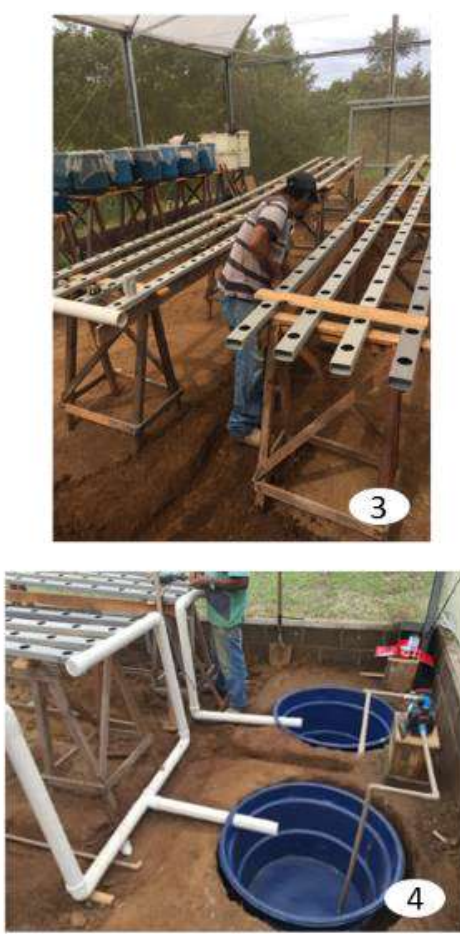
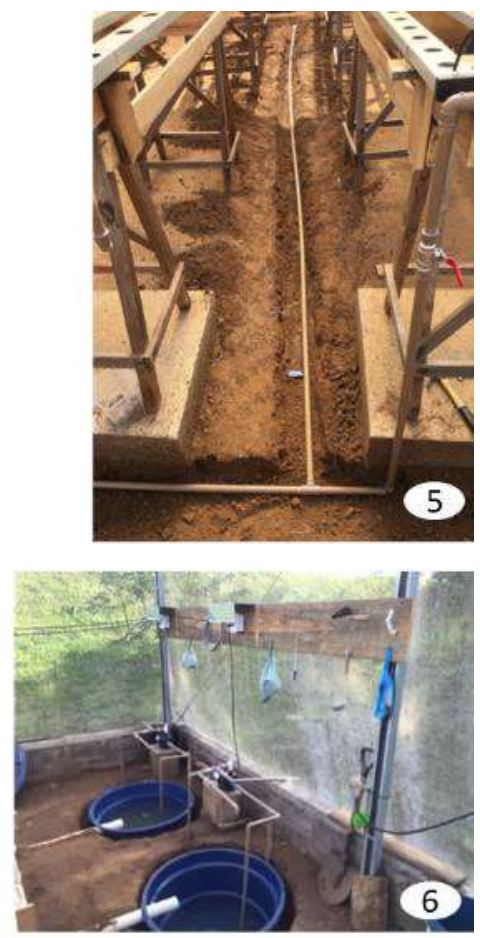

Fonte: Autoria própria (2016).

\subsubsection{Monitoramento da água utilizada no preparo e diluição dos biofertilizantes}

Para o preparo dos biofertilizantes assim como para a diluição feita antes da aplicação nos sistemas hidropônicos foi utilizada água disponível perto da casa de vegetação. Sendo essa uma água de poço a qual atende os atributos de potabilidade exigidos pela portaria 2914 do Ministério da Saúde. Os atributos para caracterização da água foram: $\mathrm{N}^{-\mathrm{NH}_{4}}{ }^{+}, \mathrm{N}-\mathrm{NO}_{3}{ }^{-}, \mathrm{P}, \mathrm{K}, \mathrm{Ca}, \mathrm{Mg}, \mathrm{S}$, cloreto, $\mathrm{HCO}_{3}{ }^{-}, \mathrm{B}, \mathrm{Fe}, \mathrm{Cu}, \mathrm{Zn}, \mathrm{pH}$ e condutividade elétrica. Essas análises foram terceirizadas e feitas pelo Laboratório de Saneamento, localizado na Escola de Engenharia de São Carlos (EESC/USP).

\subsubsection{Preparo das soluções nutritivas}

Após os 60 dias de fermentação, os biofertilizantes já estavam prontos para aplicação (MEDEIROS et al., 2003). Antes da aplicação em hidroponia, os biofertilizantes foram filtrados através de um pano (Figura 4.3) previamente diluídos 
ao ponto que sua condutividade elétrica estivesse com valores próximos a $2500 \mu \mathrm{S}$ $\mathrm{cm}^{-1}$ (HELBEL JUNIOR et al., 2008).

Figura 4.3 - Filtragem dos biofertilizantes já prontos, antes da diluição.

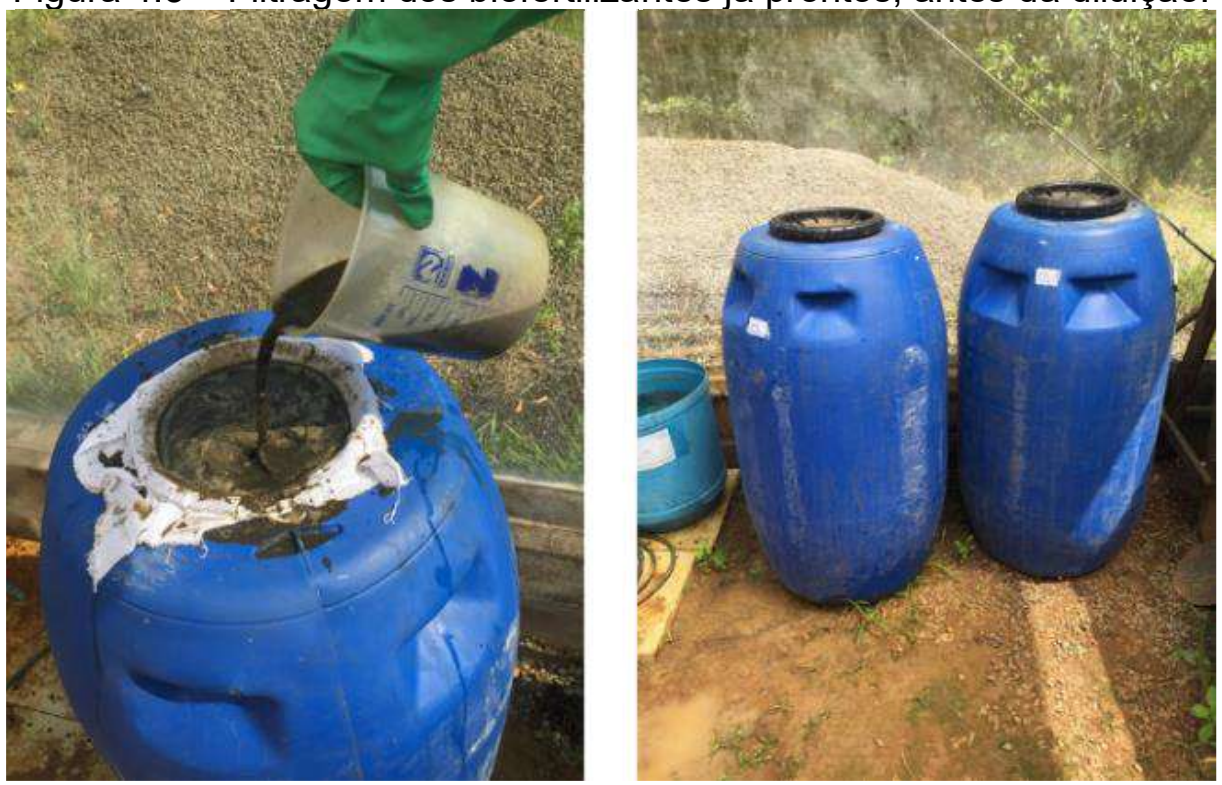

Fonte: Autoria própria (2016).

Segundo HELBEL JUNIOR et al. (2008), nessas condições de condutividade elétrica as alfaces absorvem melhor os nutrientes. Ressaltando que, para a absorção dos macro e micronutrientes faz-se necessário um monitoramento também do $\mathrm{pH}$ e da temperatura da solução nutritiva ao longo do processo de crescimento, sendo que nenhuma situação foi forçada a fim de avaliar os reais atributos do produto. Abaixo a Tabela $4.1 \mathrm{com}$ os valores de cada atributo dos biofertilizantes ao final do processo, antes da diluição para aplicação na hidroponia.

Tabela 4.1 - Valores de condutividade elétrica, $\mathrm{pH}$ e temperatura dos biofertilizantes prontos para serem diluídos e aplicados.

\begin{tabular}{ccccc} 
& M1 & M2 & M3 & M4 \\
\hline Condutividade & 4.440 & 8.470 & 12.130 & 9.050 \\
Elétrica $\left(\boldsymbol{\mu S ~ ~ c m ^ { - 1 } )}\right.$ & & & & \\
pH & 5,5 & 6,0 & 6,8 & 6,3 \\
\hline Temperatura $\left({ }^{\circ} \mathbf{C}\right)$ & 24,2 & 23,3 & 21,8 & 22,3 \\
\hline
\end{tabular}

\subsubsection{Monitoramento do processo}

Para o monitoramento da solução nutritiva ao longo do crescimento das alfaces foram feitos o monitoramento do potencial hidrogeniônico $(\mathrm{pH})$, condutividade elétrica (CE) e temperatura durante os 30 dias. Essas análises foram feitas a cada dois dias 
na caixa d'água onde estavam as soluções nutritivas, com o auxílio de um sonda (Figura 4.4).

Figura 4.4 - Monitoramento dos atributos ao longo do desenvolvimento das alfaces.
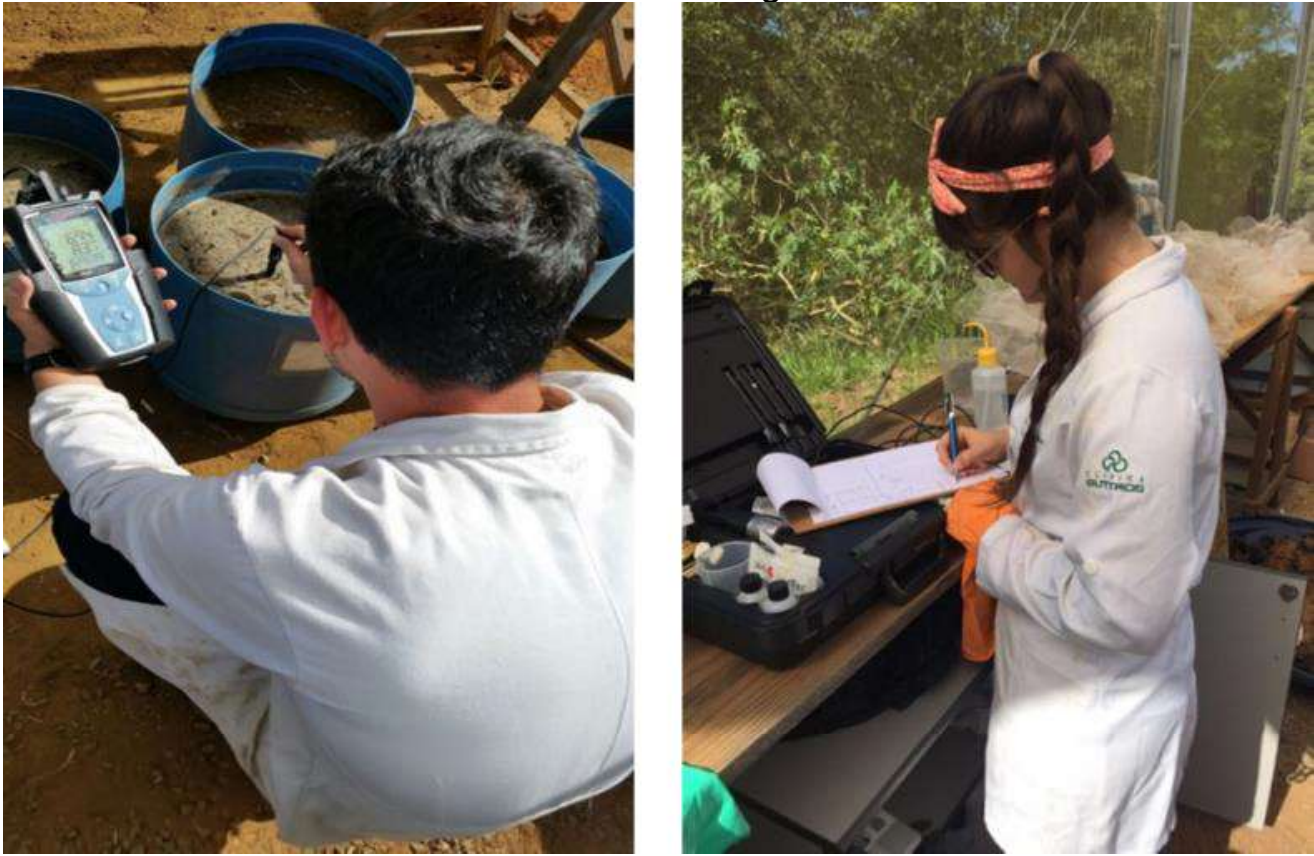

Fonte: Autoria própria (2016).

Esse monitoramento foi necessário devido à dificuldade de encontrar na literatura trabalhos que descrevam o comportamento desses biofertilizantes, logo, com o monitoramento foi possível observar se esses atendem os mesmos atributos necessários utilizados em hidroponia convencional para $\mathrm{pH}$, temperatura e condutividade. Atributos esses que apresentam uma faixa ideal onde os nutrientes são melhores assimilados.

\subsubsection{Cultivo das alfaces em hidroponia sob a aplicação dos diferentes biofertilizantes}

Após o preparo dos biofertilizantes, estes foram avaliados quanto ao desenvolvimento das alfaces nas dosagens já descritas (CE 2500 $\mu \mathrm{S} \mathrm{cm}^{-1}$ ) onde os biofertilizantes foram utilizados como substituintes da solução nutritiva convencional.

As mudas foram obtidas a partir da semeadura de sementes comerciais em bandejas de poliestireno com 128 células, preenchidas com vermiculita. $O$ transplante das mudas do berçário para as bancadas ocorreu no décimo dia após as plantas atingirem um tamanho ideal. Após o crescimento das alfaces, as mesmas foram caracterizadas quanto a biometria. 


\subsubsection{Avaliação biométrica das alfaces}

As avaliações foram realizadas considerando apenas a parte comercial da cabeça da alface, ou seja, desprezando-se as folhas amarelecidas ou secas. A matéria fresca da parte aérea foi avaliada aos 30 dias representando o momento da colheita. A circunferência da cabeça foi medida com 0 auxílio de uma fita métrica. O número de folhas foi determinado partindo-se das folhas basais até a última folha aberta. Após as anotações do peso da massa fresca, circunferência da cabeça e número de folhas, as mesmas plantas foram lavadas em água corrente e, após, em água destilada, foram secas em estufa de circulação forçada de ar a $65^{\circ} \mathrm{C}$ e pesadas em balança até atingir peso constate. $\mathrm{O}$ tamanho da folha foi avaliado na sétima folha retirada, medindo-se da base até o ápice. Por fim, a altura do pé foi medida do ponto onde terminava a raiz até o ápice da última folha.

\subsubsection{Análise microbiológica}

\section{- Coleta e preparo das amostras}

Foram coletadas três amostras aleatórias das alfaces com 30 dias de maturação (Figura 4.5). As amostras de alface para análise foram coletadas de acordo com a Associação Brasileira de Normas Técnicas (1987). Cada amostra foi acondicionada, individualmente, em sacos plásticos estéreis, fornecidos pelo Instituto Internacional de Ecologia (IIE) onde as análises foram feitas, sendo transportadas em caixas de isopor.

Figura 4.5 - Preparo das amostras para análise microbiológica. 1) Coleta das alfaces em sacos estéreis; 2) amostras prontas para análise.
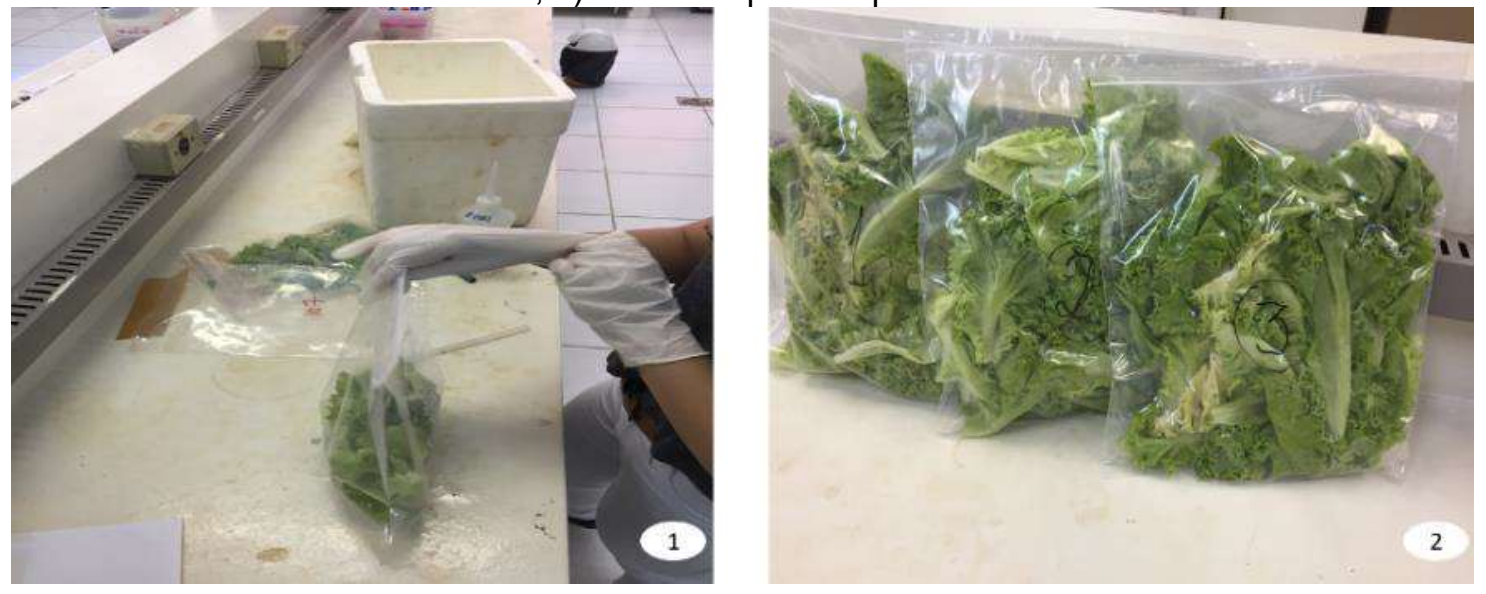

Fonte: Autoria própria (2016). 


\section{- Exame bacteriológico}

A determinação do número mais provável (NMP) de coliformes na amostra foi efetuada pela técnica de tubos múltiplos utilizando o meio A1 (CETESB, 1998). Inicialmente foi realizada a inoculação das amostras, após a inoculação de todos os volumes da amostra foi efetuada uma pré-incubação a $35^{\circ} \mathrm{C}$, durante 3 horas. Após o término da pré-incubação, os tubos foram transferidos para uma incubadora em banho-maria a $44,5^{\circ} \mathrm{C}$, para continuidade da incubação por um período de 21 horas. Procedeu-se então a leitura, considerando como resultado positivo para o teste, todos os tubos que apresentaram formação de gás no tubo de Durham.

\subsubsection{Secagem das alfaces}

Após a análise biométrica, foram separadas amostras para análise microbiológica e em seguida todas as cabeças de alfaces restantes foram colocadas em uma estufa com circulação forçada de ar a $65^{\circ} \mathrm{C}$ (Figura 4.6).

Figura 4.6 - Estufa com circulação de ar forçada utilizada para secagem das cabeças de alface antes das análises biométricas.
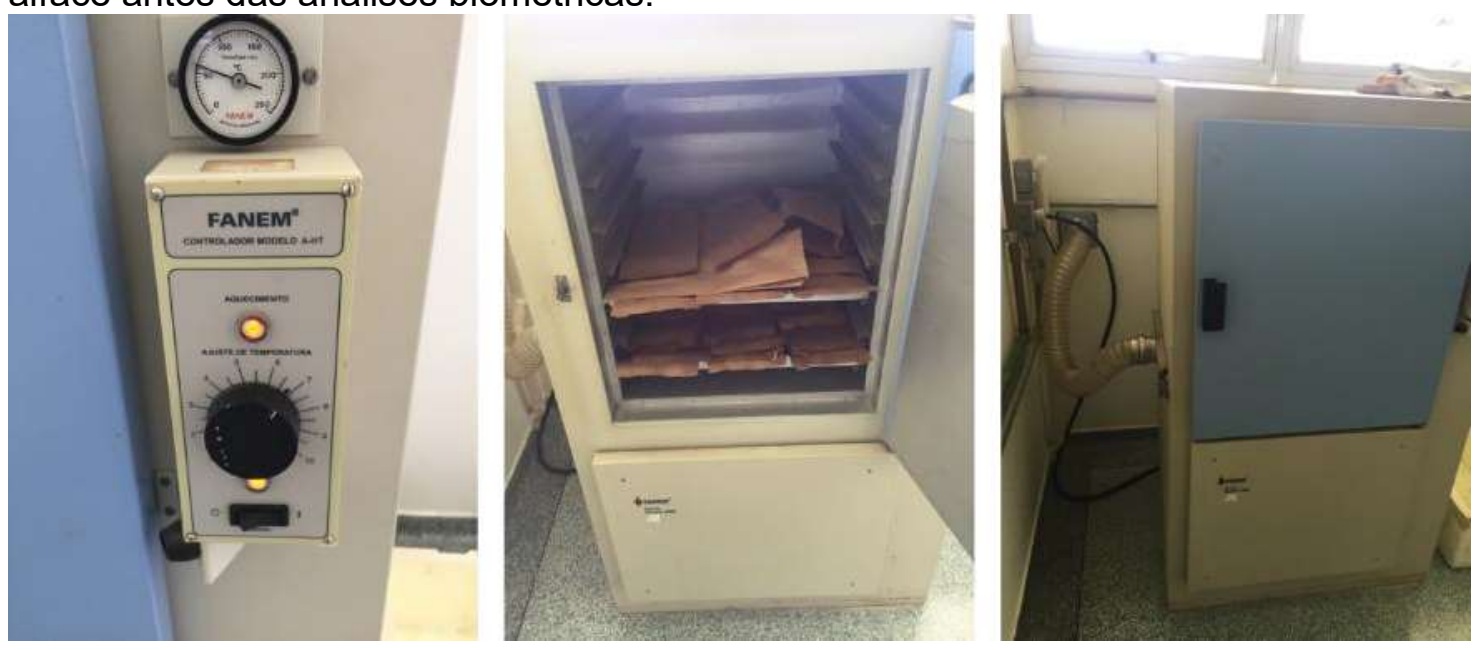

\subsection{Resultados e discussão}

4.2.1. Monitoramento da água utilizada no preparo e diluição dos biofertilizantes

A fim de verificar a qualidade da água usada para preparo das misturas, foi feita a caracterização conforme a portaria 2914 do Ministério da Saúde quanto aos atributos de: $\mathrm{N}^{-\mathrm{NH}_{4}}{ }^{+}, \mathrm{N}-\mathrm{NO}_{3}-\mathrm{P}, \mathrm{K}, \mathrm{Ca}, \mathrm{Mg}, \mathrm{S}$, cloreto, $\mathrm{HCO}_{3}{ }^{-}, \mathrm{B}, \mathrm{Fe}, \mathrm{Cu}, \mathrm{Zn}, \mathrm{pH}$ e condutividade elétrica. Os ensaios foram feitos conforme $22^{a}$ edição do Standard Methods. Os resultado das análises estão na Tabela 4.2. 
Tabela 4.2 - Atributos analisados conforme a portaria 2914 do MS, para potabilidade de água.

\begin{tabular}{|c|c|c|}
\hline Atributos & Unidade & Resultado \\
\hline Condutividade elétrica & $\mathrm{uS} \mathrm{cm}^{-1}$ & 46,35 \\
\hline Cloretos & $\mathrm{mg} \mathrm{L}^{-1}$ & 2,40 \\
\hline Fósforo & $\mathrm{mg} \mathrm{L}^{-1}$ & 0,11 \\
\hline Nitrogênio amoniacal & $\mathrm{mg} \mathrm{L}^{-1}$ & $<0,01$ \\
\hline Nitrogênio nitrato & $\mathrm{mg} \mathrm{L}^{-1}$ & 0,05 \\
\hline $\mathrm{pH}$ & NA & 6,99 \\
\hline Potássio & $\mathrm{mg} \mathrm{L}^{-1}$ & 3,50 \\
\hline Cálcio & $\mathrm{mg} \mathrm{L}^{-1}$ & 2,74 \\
\hline Magnésio & $\mathrm{mg} \mathrm{L}^{-1}$ & 1,62 \\
\hline Boro & $\mathrm{mg} \mathrm{L}^{-1}$ & 0,80 \\
\hline Ferro & $\mathrm{mg} \mathrm{L}^{-1}$ & $<0,005$ \\
\hline Cobre & $\mathrm{mg} \mathrm{L}^{-1}$ & $<0,003$ \\
\hline Manganês & $\mathrm{mg} \mathrm{L}^{-1}$ & 6,99 \\
\hline Zinco & $\mathrm{mg} \mathrm{L}^{-1}$ & 0,03 \\
\hline
\end{tabular}

Segundo os dados obtidos nas análises da água, pode-se dizer que esta encontra-se apta para consumo, logo, pode ser usada no preparo dos biofertilizantes.

\subsubsection{Características finais dos biofertilizantes}

$\mathrm{Na}$ hidroponia existem diversos fatores que podem afetar a disponibilidade dos nutrientes para as alfaces, tais como a composição do biofertilizante, a temperatura, o pH da solução nutritiva e condutividade elétrica, dentre outros. Com isso, fez-se necessário um monitoramento ao longo de todo período de crescimento das alfaces.

Segundo SEDIYAMA e PEDROSA (2007), o pH da solução nutritiva deve ser mantido na faixa de 5,5 a 6,5 , sendo esta a mais adequada para absorção de nutrientes pelas espécies vegetais. 
Valores altos de $\mathrm{pH}$, maiores que 7,5 podem provocar a formação de carbonatos de cálcio e magnésio impedindo que estes sejam absorvidos pelas alfaces.

A seguir são mostrados nas Tabelas 4.3 e 4.4 os valores obtidos dos atributos para cada biofertilizante no final do preparo.

Tabela 4.3 - Valores dos atributos dos biofertilizantes no final do preparo.

\begin{tabular}{ccccccc} 
Mistura & $\mathbf{p H}$ & $\mathbf{C E}\left(\boldsymbol{\mu S} \mathbf{~ c m}^{-1}\right)$ & Temp. $\left({ }^{\circ} \mathbf{C}\right)$ & IS (\%) & AL ( $\left.{ }^{\circ} \mathbf{D}\right)$ & COT $\left(\mathbf{m g ~ L}^{-1}\right)$ \\
\hline M1 & $4,96 \pm 0,06$ & $2.963 \pm 0$ & $20,7 \pm 0,3$ & $27,5 \pm 6,88$ & $12,2 \pm 3,62$ & $8745 \pm 124$ \\
M2 & $5,29 \pm 0,10$ & $7.850 \pm 0$ & $20,3 \pm 0,2$ & $72,9 \pm 5,7$ & $6,3 \pm 1,5$ & $7445 \pm 242$ \\
& & & & & & \\
M3 & $7,04 \pm 0,14$ & $9,6 \pm 1,0$ & $21,4 \pm 0,5$ & $89,3 \pm 9,3$ & $8,7 \pm 0,3$ & $12080 \pm 76$ \\
M4 & $6,39 \pm 0,17$ & $6,45 \pm 0,18$ & $20,1 \pm 0,3$ & $59,9 \pm 1,6$ & $8,1 \pm 3,3$ & $7364 \pm 82$ \\
\hline
\end{tabular}

IS = Índice salino; $\mathrm{AL}=$ ácido lático

Tabela 4. 4 - Valores dos macronutrientes principais (NPK) nos biofertilizantes no final do

\begin{tabular}{|c|c|c|c|}
\hline \multirow{2}{*}{ Mistura } & $\mathbf{N}$ & P & \multirow{2}{*}{$\begin{array}{c}\mathrm{K} \\
\left(\mathrm{mg} \mathrm{L}^{-1}\right)\end{array}$} \\
\hline & $\left(\mathrm{mg} \mathrm{L}^{-1}\right)$ & $\left(\mathrm{mg} \mathrm{L}^{-1}\right)$ & \\
\hline M1 & $382 \pm 21$ & $19,4 \pm 1,2$ & $1184 \pm 43$ \\
\hline M2 & $675 \pm 21$ & $27,5 \pm 4,5$ & $1303 \pm 39$ \\
\hline M3 & $739 \pm 87$ & $8,1 \pm 1,2$ & $3009 \pm 11$ \\
\hline M4 & $93,8 \pm 5,3$ & $4,6 \pm 0,1$ & $2303 \pm 6$ \\
\hline
\end{tabular}

A discussão destes resultados foi apresentada no Capítulo 1 - Preparo e caracterização dos biofertilizantes.

\subsubsection{Monitoramento dos biofertilizantes ao longo do cultivo das alfaces}

Após os 60 dias de fermentação, os biofertilizantes estavam prontos para aplicação em sistema hidropônico. As alfaces tem um ciclo de crescimento em torno de 25-30 dias, com isso também foi feito o monitoramento ao longo desse período com o intuito de manter os atributos $\mathrm{pH}$, condutividade elétrica e temperatura nas condições adequadas para o crescimento da cultura em questão. Foi feito dessa forma devido à complexidade da composição dos biofertilizantes, sendo mais fácil o controle da condutividade do que o controle de cada nutriente separadamente. $O$ resultado 
com isso foi avaliado não pela concentração dos nutrientes, mas sim mantendo a solução nutritiva com condutividade elétrica próximo do ideal para as alfaces, ou seja, 2000-2500 $\mu \mathrm{S} \mathrm{cm}^{-1}$.

A seguir, as Figuras com os valores de monitoramento ao longo do período de crescimento da cultura ilustram o processo.

- $\mathrm{pH}$

Como pode-se observar (Figura 4.6), todas as misturas seguiram uma tendência. Para $\mathrm{o} \mathrm{pH}$, pode-se observar que tanto para M3 e M4 os valores permaneceram próximos a faixa ideal para absorção de nutrientes $(\mathrm{pH}=5-7)$ mas em relação a M1 e M2 esses valores foram menores. Esse fato pode estar ligado, junto a outros fatores, ao crescimento mais lento das culturas às quais foram aplicadas as misturas M1 e M2, mas isso torna-se mais claro ao longo deste capítulo onde os resultados biométricos dos cultivares serão mostrados.

Figura 4.6 - Valores de $\mathrm{pH}$ ao longo dos 30 dias de crescimento das alfaces.

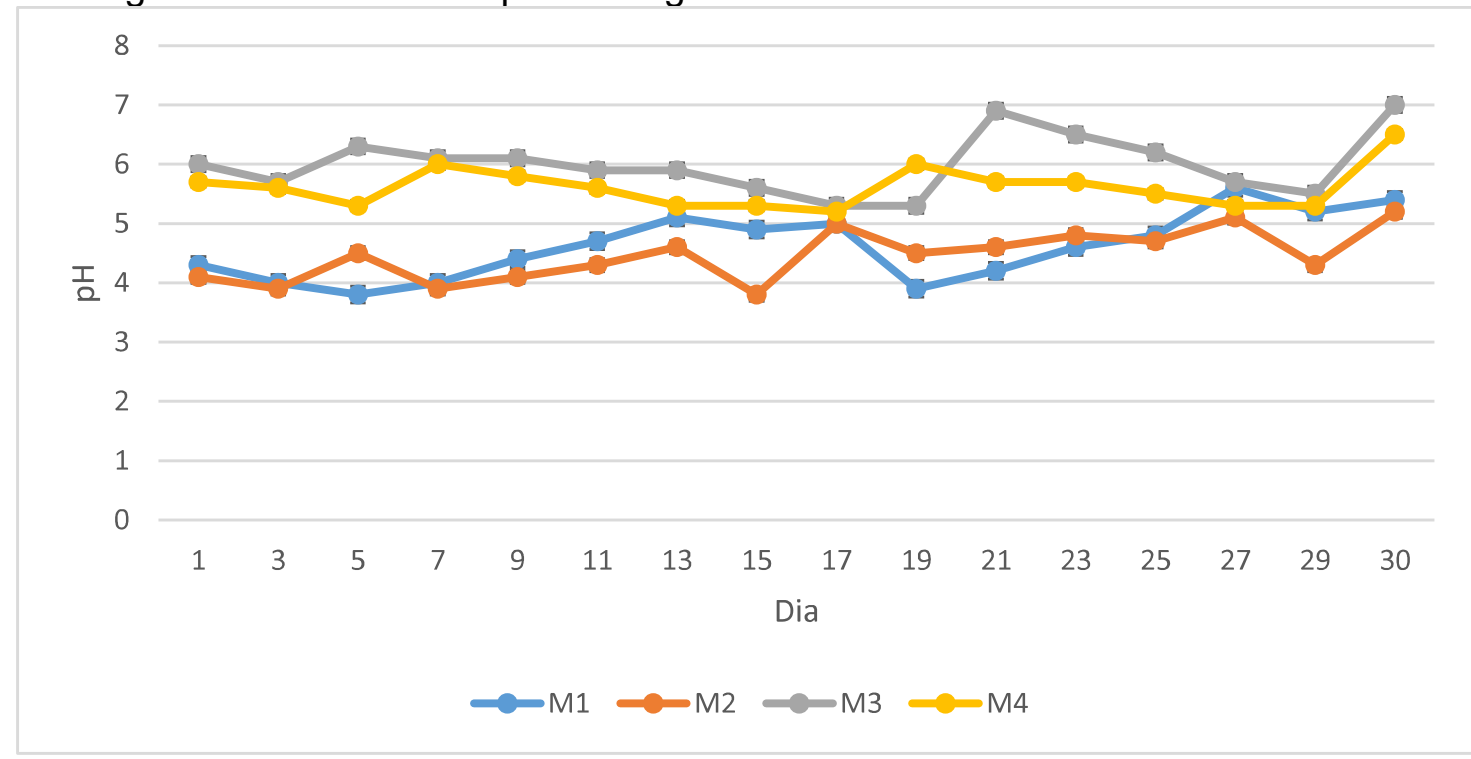

Os baixos valores de pH para a M1 e M2 estão associados à presença de bagaço de laranja em seu preparo, resíduo este que possui caráter ácido dando essa característica ao produto.

\section{- Condutividade elétrica}

A condutividade elétrica foi tentativamente mantida constante ao longo do crescimento das alfaces. Para isso, foi feita a adição do biofertilizante à medida que a 
CE diminuía nas caixas de solução nutritiva, na tentativa de manter os valores de CE próximo a 2500-3000 $\mu \mathrm{S} \mathrm{cm} \mathrm{cm}^{-1}$, que, segundo COSTA et al. (2001) e BARBIERI et al. (2010), é esse o valor ideal da concentração da solução nutritiva. Esse comportamento pode ser observado na Figura 4.7.

Figura 4. 7 - Valores de condutividade elétrica (CE) ao longo dos 30 dias de crescimento das alfaces.

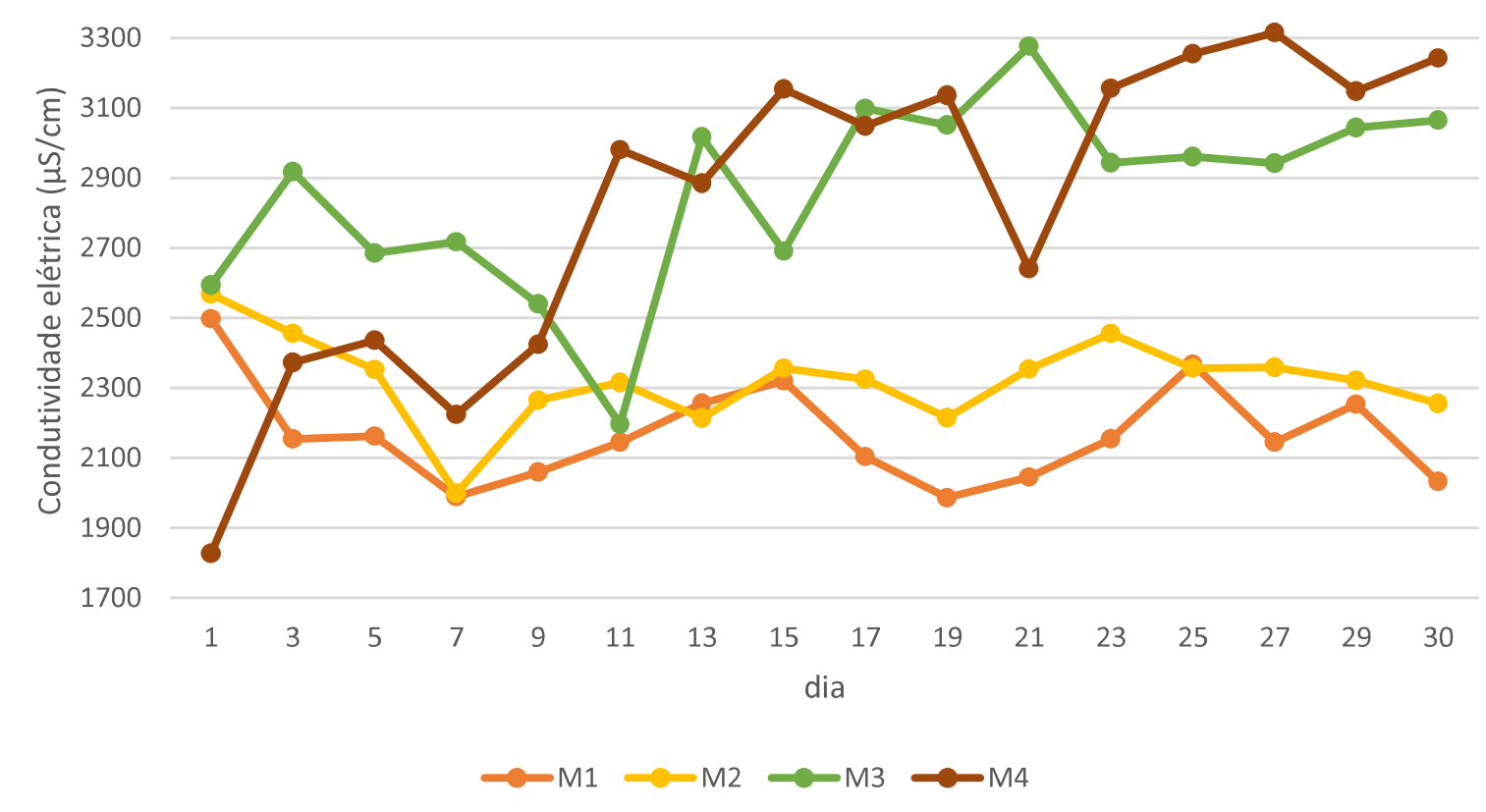

Mais uma vez as misturas onde se manteve a concentração da solução nutritiva próximo do ideal foram a M3 e M4, uma vez que M1 e M2 apresentaram valores mais baixos de CE, sendo necessária a adição de mais solução nutritiva a fim de aumentar o valor de CE.

\section{- Temperatura}

A temperatura não foi controlada. Assim, em dias mais quentes, a temperatura interna na casa de vegetação foi mais elevada enquanto que em dias mais frios a temperatura alcançou valores próximos a $20^{\circ} \mathrm{C}$. Segundo LEE \& CHONG (1996) a faixa ideal para temperatura da solução nutritiva é de $25-35^{\circ} \mathrm{C}$. A variação da temperatura ao longo do crescimento das alfaces pode ser observada na Figura 4.8.

Nos valores de temperatura pode-se perceber que a M1 e M2 tiveram os maiores valores, sendo que isso não foi um problema pois mesmo em valores mais elevados, todas as misturas se mantiveram dentro da faixa aceitável para a solução nutritiva de hidroponia $\left(20-35^{\circ} \mathrm{C}\right)$. 
Figura 4. 8 - Valores de temperatura ao longo dos 30 dias de crescimento das alfaces.

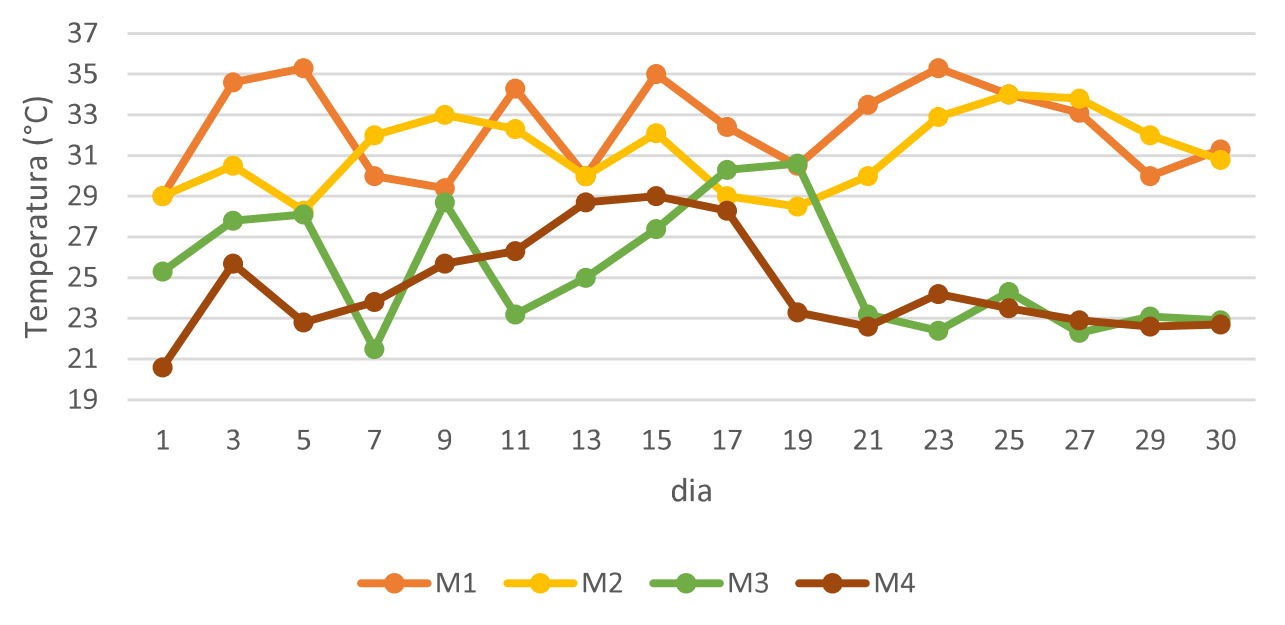

\subsubsection{Cultivo das alfaces}

\section{- Doenças e patologias encontradas}

As alfaces foram acompanhadas visualmente durante os 30 dias de cultivo. Durante os primeiros dias observou-se nas misturas onde o bagaço de laranja estava presente (M1 e M2) formação de um lodo nas raízes o que impedia o desenvolvimento das alfaces (Figura 4.9).

Figura 4. 9 - Podridão das raízes sob aplicação de M1 e M2 em alface hidropônica, formação de lodo causada por Pythium aphanidermatum.
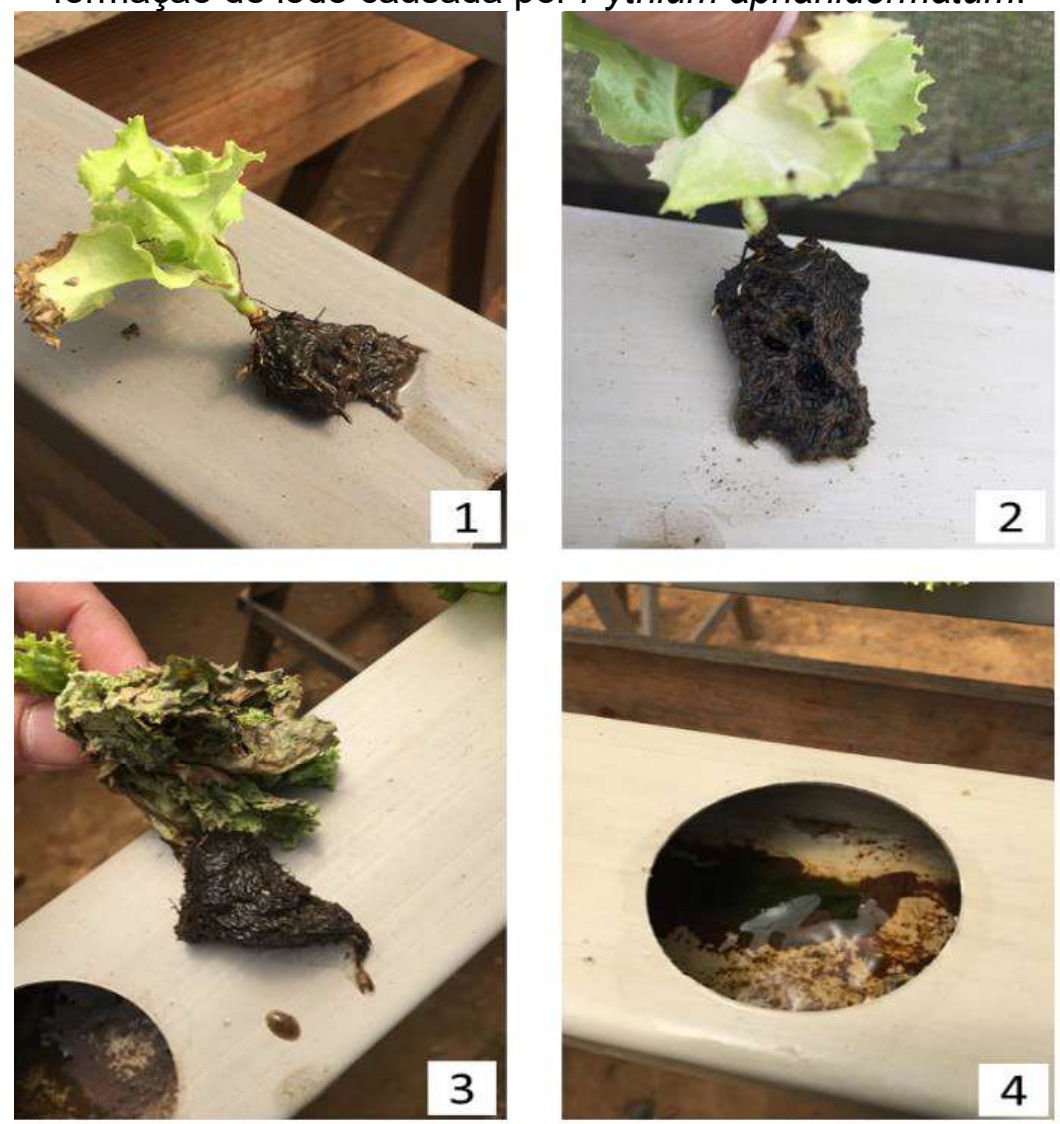
Como pode-se observar na Figura 4.9, nas alfaces onde foram aplicadas M1 e M2 desenvolveu-se um lodo nas raízes nos primeiros dias, o que causou a morte de algumas alfaces e quando vingaram o crescimento foi comprometido em relação ao desenvolvimento da cabeça. Segundo CORRÊA et al. (2010), após a contaminação essa espécie pode ser combatida com o aumento da temperatura da solução nutritiva, com isso, pode-se prever que as cabeças de alfaces que se desenvolveram foi porque a solução nutritiva teve sua temperatura aumentada pelo processo fermentativo e com isso houve a morte dos fungos.

Outro problema encontrado nas alfaces, nesse caso no geral para todas as misturas, foi o aparecimento de manchas brancas em algumas folhas, como mostrado na Figura 4.10.

Figura 4. 10 - Doença causada pelo omiceto Bremia Lactucae Regel, conhecida como míldio
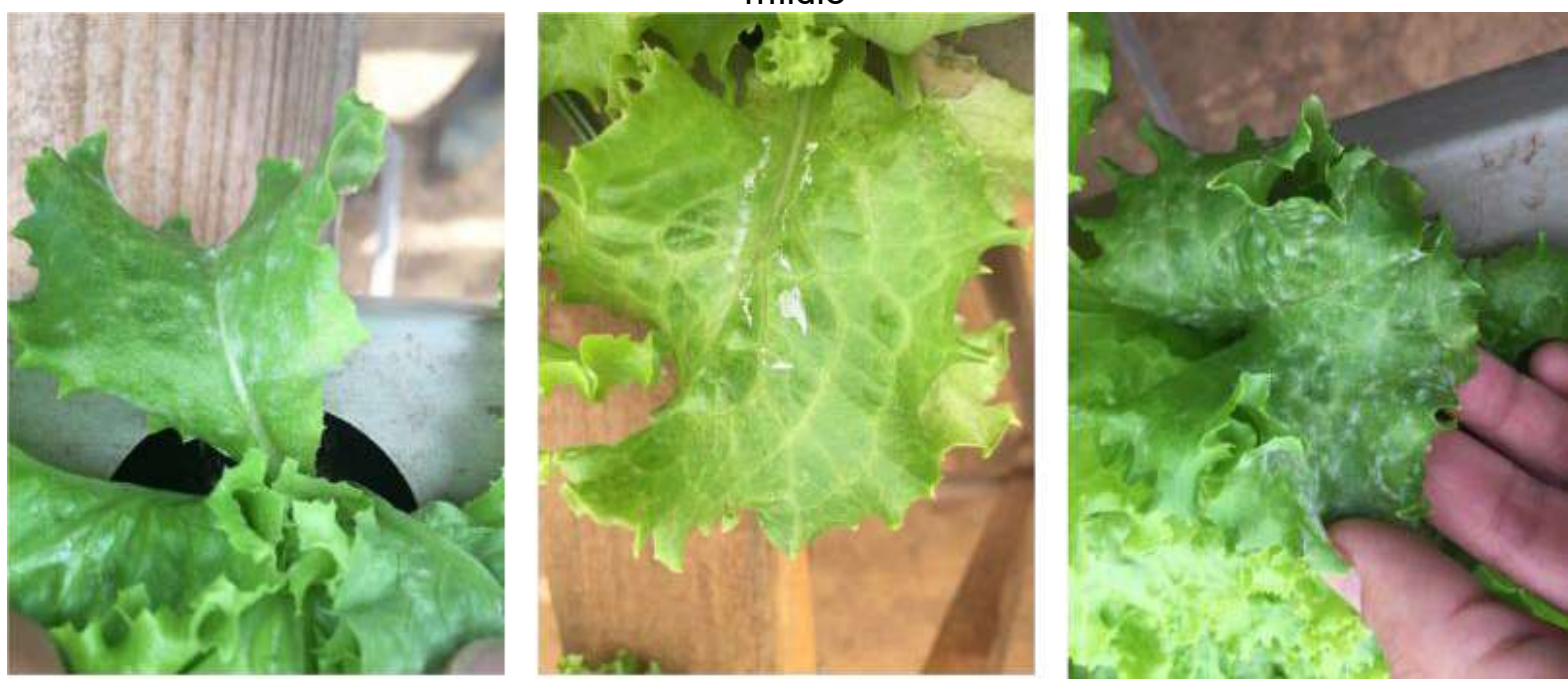

Segundo SOUZA et al. (2011), essas manchas são ocasionadas pelo omiceto Bremia Lactucae Regel (Figura 4.10), sendo a doença conhecida como míldio, problema grave pois aumenta os custos da produção. O míldio é a mais importante doença nas regiões de temperatura amena e úmida, as quais coincidem com as condições observadas nas grandes regiões produtoras de alface do estado de São Paulo. Segundo os autores, o controle dessa doença é feito com pulverização de fungicidas mas corre-se o risco dos fungos em questão se tornarem resistentes. No presente trabalho nenhum fungicida foi aplicado, uma vez que o objetivo geral foi a utilização de dos princípios da agricultura orgânica, onde nenhum veneno é aplicado. Mas o que se pode observar foi que essas manchas desapareceram com o tempo, sendo um indício de que os biofertilizantes ao serem aplicados nas culturas, além de atuarem como fonte suplementar de nutrientes para as plantas, podem também 
contribuir para o aumento da resistência natural das espécies ao ataque de pragas e de patógenos, além de exercerem ação direta sobre fitoparasitas, pela presença de substâncias tóxicas na calda (ALVES et al., 2009). A comprovação do desaparecimento da doença foi a análise microbiológica feita das alfaces: nenhum microbiológico foi encontrado. Esses resultados microbiológicos serão mostrados logo a frente. Segundo CASTOLDI (2011), o omiceto Bremia Lactucae Regel é bastante comum de ser encontrado em alfaces nessa região de São Paulo, devido ao clima da região.

\subsubsection{Análises microbiológicas}

Para aferição se as alfaces estariam aptas para consumo foi feita a análise microbiológica das folhas e nos biofertilizantes a fim de analisar a presença ou não de contaminantes microbiológicos.

Um dos indicadores utilizados para verificar as condições de higiene de hortaliças é a contagem de coliformes totais e de coliformes termotolerantes (BRASIL, 2001). Os coliformes termotolerantes são um importante gênero de microrganismo responsável por intoxicações alimentares. A maioria dos sorotipos desse microrganismo é patogênica ao ser humano, apresentando diferenças de sintomatologia em decorrência da variação no mecanismo de patogenicidade, além da idade do indivíduo infectado e da resposta imunológica (FRITTOLI et al. 2014). As contagens de coliformes em hortaliças são utilizadas como atributos indicadores de higiene (BRASIL, 2001). O índice de coliformes totais é utilizado para avaliar as condições higiênicas e os coliformes termotolerantes são utilizados como indicadores da qualidade sanitária do alimento, servindo também como indicadores da presença de microrganismos patogênicos (OLIVEIRA, 2005). Os coliformes totais são compostos por grupos de bactérias gram-negativas que não originam esporos e fermentam a lactose, produzindo ácido e gás à $35-37^{\circ} \mathrm{C}$. Este grupo é formado por um conjunto de bactérias que inclui os gêneros Klebsiella sp., Escherichia sp., Serratia $s p$. Enterobacter sp. e Erwinia sp. Já os coliformes termotolerantes são também conhecidos como "coliformes fecais" e suportam uma temperatura superior a $40^{\circ} \mathrm{C}$. No grupo de coliformes termotolerantes está presente a bactéria Gram-negativa Escherichia coli, que, ao ser ingerida pelo homem, pode provocar sintomas 
desagradáveis, brandos ou agressivos, dependendo do grau de contaminação (CRUZ; CENCI; MAIA, 2006).

Conforme a Tabela 4.5, pode-se observar que foram encontradas em todas as amostras, tanto nas alfaces como nos biofertilizantes, presença de coliformes totais sendo esse não prejudicial à saúde humana. Segundo BERBARI; PASCHOALINO; SILVEIRA (2001), é considerada elevada a contagem de Coliformes totais quando superior a $1,1 \times 10^{2} \mathrm{NMP}$, podendo estes alimentos representar riscos para o consumidor. Vale ressaltar que a matéria prima usada no preparo dos biofertilizantes são esterco de aves e bovino em alguns casos, e por isso a detecção de coliformes totais. A detecção de coliformes totais não é necessariamente um indicativo de contaminação fecal, pois o grupo designado como coliformes totais engloba um grande número de bactérias, entre elas a Escheríchia coli, exclusivamente de origem fecal e que dificilmente multiplica-se fora do trato intestinal, no entanto engloba também outras bactérias dos gêneros Citrobater, Eriterobacter e Klebsiella, igualmente identificadas pelas técnicas laboratoriais como coliformes totais e que são comumente encontradas no solo e nos vegetais (PAIVA, 2011).

Tabela 4.5 - Valores de análises microbiológica feitas nas alfaces e nos biofertilizantes.

Coliformes

Amostra

totais

(NMP/100mL)
Coliformes

Avaliação fecais

(NMP/100mL)
Avaliação

Próprio

Impróprio

\begin{tabular}{l|c|c|c|c|c}
\multirow{2}{*}{$\begin{array}{c}\text { Biofertilizante } \\
\text { líquido }\end{array}$} & M2 & $>2419,6$ & Impróprio & 46110 & Impróprio \\
\cline { 2 - 6 } & M3 & $>2419,6$ & Impróprio & Ausente & Próprio \\
\cline { 2 - 6 } & M4 & $>2419,6$ & Impróprio & $>2419,6$ & Impróprio \\
\hline \multirow{4}{*}{ Alfaces } & M1 & $>2419,6$ & Impróprio & Ausente & Próprio \\
\cline { 2 - 6 } & M2 & $>2419,6$ & Impróprio & 488,4 & Impróprio \\
\cline { 2 - 6 } & M3 & $>2419,6$ & Impróprio & Ausente & Próprio \\
\cline { 2 - 6 } & M4 & $>2419,6$ & Impróprio & Ausente & Próprio \\
\hline
\end{tabular}

Já para as análises de coliformes termotolerantes (coliformes fecais), sendo este um indicativo de que as alfaces não estão aptas para consumo, os resultados foram mais satisfatórios, pois embora tenha sido encontrada a espécie Escherichia Coli no biofertilizantes M2 e M4, quando a análise foi nas folhas das alfaces esse 
patógeno somente foi detectado sob o cultivo da mistura M2, e ainda assim em quantidades pequenas. Em FRITTOLI et al. (2014) foi feito um estudo de hortaliças minimamente processadas, sendo estas já higienizadas para consumo e mesmo assim foi encontrada presença de coliformes fecais na maioria das verduras. A Legislação Brasileira, ANVISA - Resolução RDC-12, indica como padrão microbiológico para hortaliças, legumes e similares - frescas, in natura, preparadas (descascadas ou selecionadas ou fracionadas), sanificadas, refrigeradas ou congeladas para consumo a contagem de $10^{2}$ UFC de coliformes fecais por grama de produto. Vale lembrar que as análises feitas neste trabalho foram sem higienização prévia das folhas das alfaces, sendo que após a higiene correta, pode-se esperar que esta pequena quantidade encontrada em M2 possa ser diminuída, tornando as alfaces aptas para consumo. Os laudos das análises encontram-se em anexo I.

\subsubsection{Avaliação biométrica das alface}

Após o preparo dos biofertilizantes, os mesmos foram aplicados em cultivo de alface hidropônica durante 30 dias, sendo avaliadas visualmente quanto ao crescimento e no final do cultivo foram feitas análises biométricas das alfaces.

Pôde-se perceber que os resultados das caracterizações das misturas ao longo do preparo foram representativas, pois como observamos, a M3 apresentou os melhores resultados agronômico, e isso foi possível perceber quando estes foram aplicados na hidroponia.

Em um primeiro momento, já é possível perceber a eficiência agronômica da M3 em relação às outras misturas, tomando cuidado que essa tendência foi percebida apenas com atributos visuais onde as alfaces sob cultivo da M3 se mostraram maiores e mais vistosas em relação às outras misturas, como pode ser visto na Figura 4.11.

Outro fator importante percebido visualmente foi a coloração das alfaces, sendo que para M3 as mesmas se mantiveram com uma coloração verde viva e constante durante os 30 dias. $\mathrm{O}$ que não se pode perceber para as misturas M1, M2 e M4, pois percebeu-se a diferença de tons de verde ao longo dos dias, isso indica deficiência de algum nutriente. 
Figura 4.11 - Análise visual das alfaces em relação aos cultivos sob cada mistura.
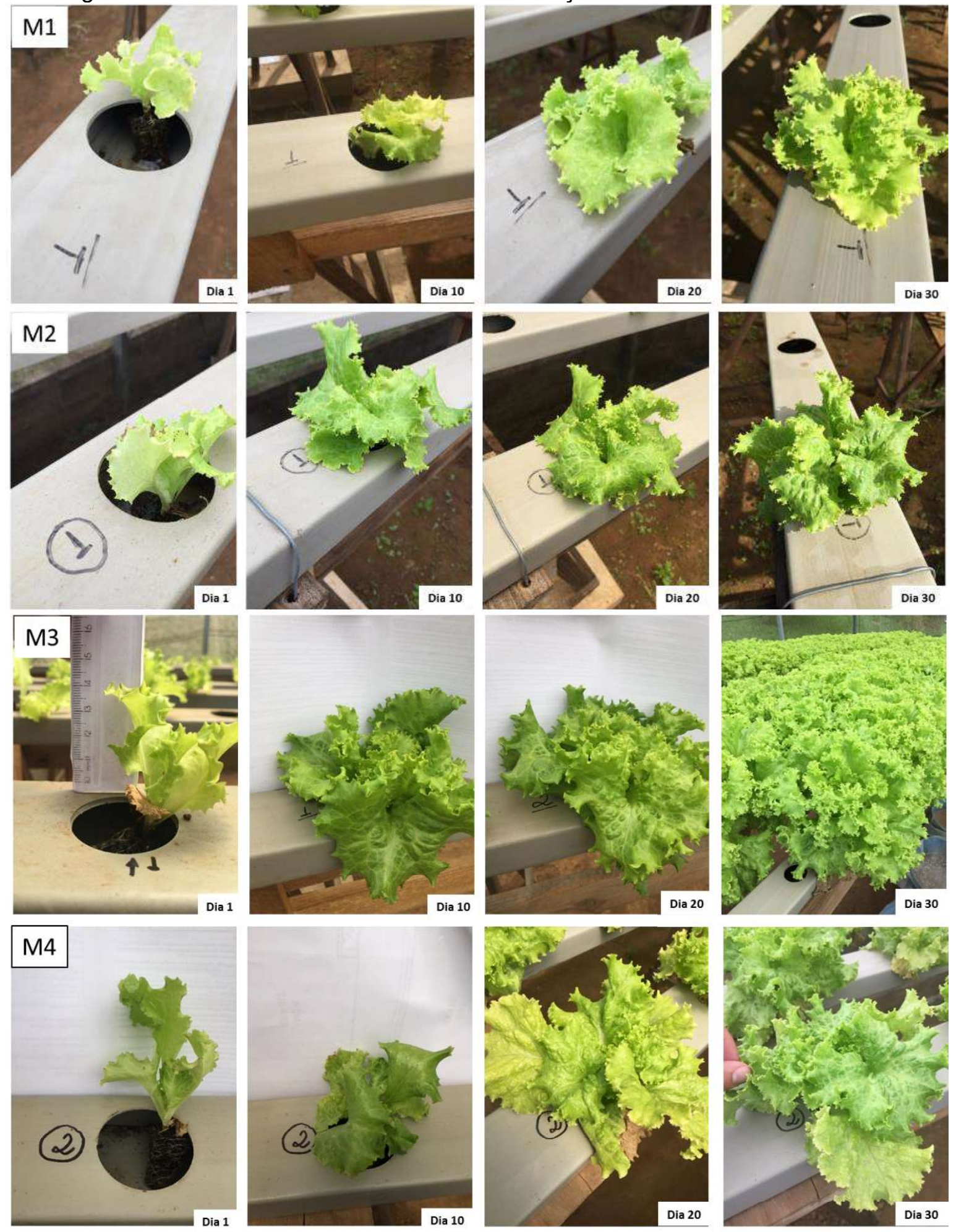

A seguir são apresentadas as análises biométricas das alfaces sob o cultivo de cada mistura. 


\subsubsection{Análise estatística das avaliações biométricas}

A Tabela 4.6 mostra os resultados de cada atributo biométrico, além do teste estatístico de Tukey, que compara a diferença significativa entre cada mistura dentro de um determinado atributo analisado, a fim de comprovar se estas se diferem estatisticamente.

Tabela 4. 6 - Valores das análises biométricas feitas nas alfaces seguido da análise estatística (MFPA - massa fresca da parte aérea; Circunferência da cabeça; número de folhas; MSPA - massa seca da parte aérea; comprimento da folha; altura do pé).
Atributo
M1
M2
M3
M4

\begin{tabular}{|c|c|c|c|c|}
\hline MFPA (g planta-1) & $11,29 \pm 1,22 \mathrm{a}$ & $8,39 \pm 2,38 \mathrm{a}$ & $\begin{array}{c}152,70 \pm 9,94 \\
\mathrm{~b}\end{array}$ & $\begin{array}{c}102,38 \pm 16,27 \\
\mathrm{c}\end{array}$ \\
\hline $\begin{array}{c}\text { Circunferência da } \\
\text { cabeça (cm) }\end{array}$ & $26,86 \pm 1,62 \mathrm{a}$ & $19,27 \pm 2,46 \mathrm{~b}$ & $71,64 \pm 6,89 \mathrm{c}$ & $53,67 \pm 6,90 \mathrm{~d}$ \\
\hline $\begin{array}{c}\text { Número de folhas } \\
\text { (folhas planta }\end{array}$ & $8 \pm 2 \mathrm{a}$ & $6 \pm 1 \mathrm{a}$ & $20 \pm 3 \mathrm{~b}$ & $17 \pm 3 \mathrm{c}$ \\
\hline $\begin{array}{c}\text { MSPA (g planta } \\
\text { MS }\end{array}$ & $0,81 \pm 0,63 \mathrm{a}$ & $0,49 \pm 0,34 \mathrm{a}$ & $7,74 \pm 1,84 \mathrm{~b}$ & $5,57 \pm 2,36 \mathrm{c}$ \\
\hline $\begin{array}{c}\text { Comprimento da folha } \\
\text { (cm) }\end{array}$ & $8,46 \pm 2,35 \mathrm{a}$ & $7,41 \pm 1,78 \mathrm{a}$ & $19,90 \pm 2,27 \mathrm{~b}$ & $15,82 \pm 1,73 \mathrm{c}$ \\
\hline Altura do pé (cm) & $9,87 \pm 2,36 \mathrm{a}$ & $9,63 \pm 1,14 \mathrm{a}$ & $24,26 \pm 2,87 \mathrm{~b}$ & $19,54 \pm 2,63 \mathrm{c}$ \\
\hline
\end{tabular}

Médias seguidas pela mesma letra na linha não diferem significativamente entre si pelo teste de Tukey $(\mathrm{P}<0,05)$.

\section{- MFPA}

A mistura M3 mostrou-se melhor quanto aos dados da matéria fresca.

\section{- CIRCUNFERÊNCIA DA CABEÇA}

Todas as medidas foram diferentes entre si, sendo obtido com a M3 o melhor resultado.

\section{- NÚMERO DE FOLHAS}

A mistura M3 foi a melhor quanto à produção de folhas.

\section{- MSPA}

Como esperado devido ao resultado de MSPA, nesse atributo, mais uma vez, com M3 obtiveram-se os melhores resultados.

\section{- COMPRIMENTO DAS FOLHAS}

Apenas as misturas M1 e M2 foram estatisticamente iguais. Assim, da diferença estatística dos dados de M3 e M4, pode ser dito que o fertilizante M3 foi o melhor quanto ao desenvolvimento das folhas da alface. 


\section{- ALTURA DO PÉ}

A M3 favoreceu o melhor desenvolvimento.

\subsubsection{Atributos biométricos analisados}

\section{Matéria fresca da parte aérea}

Como pode-se perceber sobre o primeiro dado mostrado na Figura 4.12 na análise biométrica das alfaces em relação à massa fresca da parte aérea foi que em comparação com as quatro misturas (M1, M2, M3 e M4) a mistura M3 mais uma vez mostrou os melhores resultados em relação às outras, comprovando os resultados iniciais de caracterização dos biofertilizantes, onde com a M3 obtiveram-se os melhores valores agronômicos.

Figura 4. 12 - Valores de massa fresca da parte aérea em cada mistura.

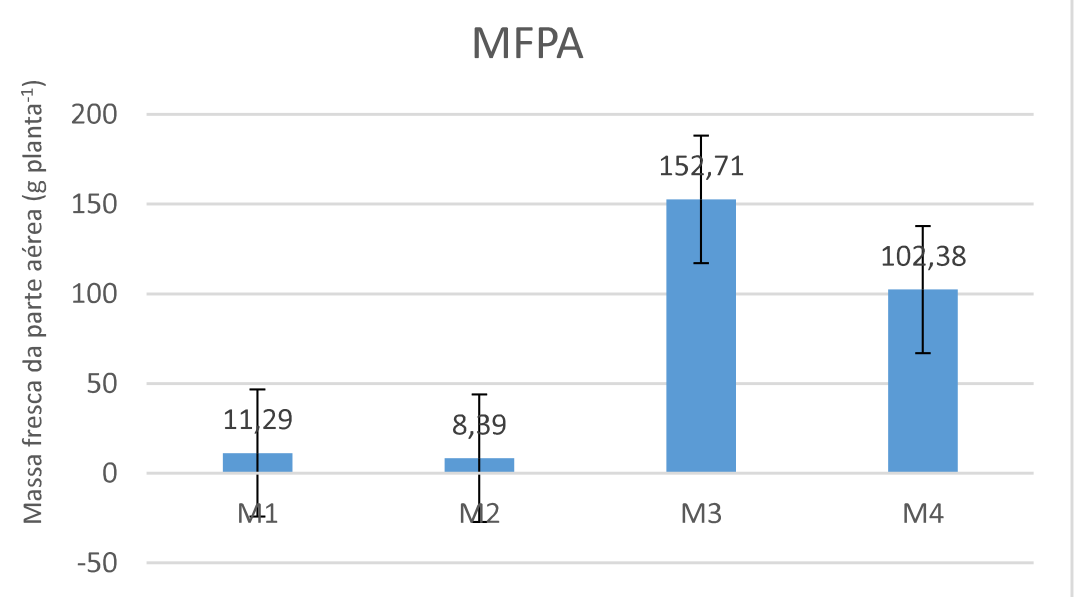

Enquanto que com a M3 atingiram-se valores na faixa de $152 \mathrm{~g}_{\text {planta-1, }}$, seguido de M4 com $102 \mathrm{~g} \mathrm{planta}^{-1}$, com as misturas M1 e M2 não atingimos valores significantes, uma vez que não houve desenvolvimento das cabeças de alface devido à deficiência de alguns nutrientes na solução nutritiva. Esse fato é devido à composição do biofertilizante, onde nas misturas M1 e M2 temos em comum o bagaço de laranja que desde o início mostrou-se como um problema quando utilizado no preparo das misturas, devido às suas características, principalmente de acidez.

Trabalhos da literatura, como SANTI et al. (2013), mostraram valores de MFPA próximo a 150-200 $\mathrm{g} \mathrm{planta}^{-1}$, sendo estes os valores encontrados no presente trabalho para M3 e M4, podendo-se considerar que esses resultados foram satisfatórios, o que não se pode dizer para as alface onde se aplicou M1 e M2, as cabeças não chegaram a $15 \mathrm{~g}_{\text {planta }}{ }^{-1}$. 


\section{Circunferência da cabeça}

Devido ao mal desenvolvimento das cabeças de alfaces quando aplicados as misturas M1 e M2, mais uma vez para atributo circunferência da cabeça adotou-se a mesma sequência, onde a M3 mostrou-se satisfatória, atingindo valores bem maiores em relação a M1 e M2, como pode ser visto na Figura 4.13.

Figura 4. 13 - Valores de circunferência da cabeça sob cultivo de cada mistura.

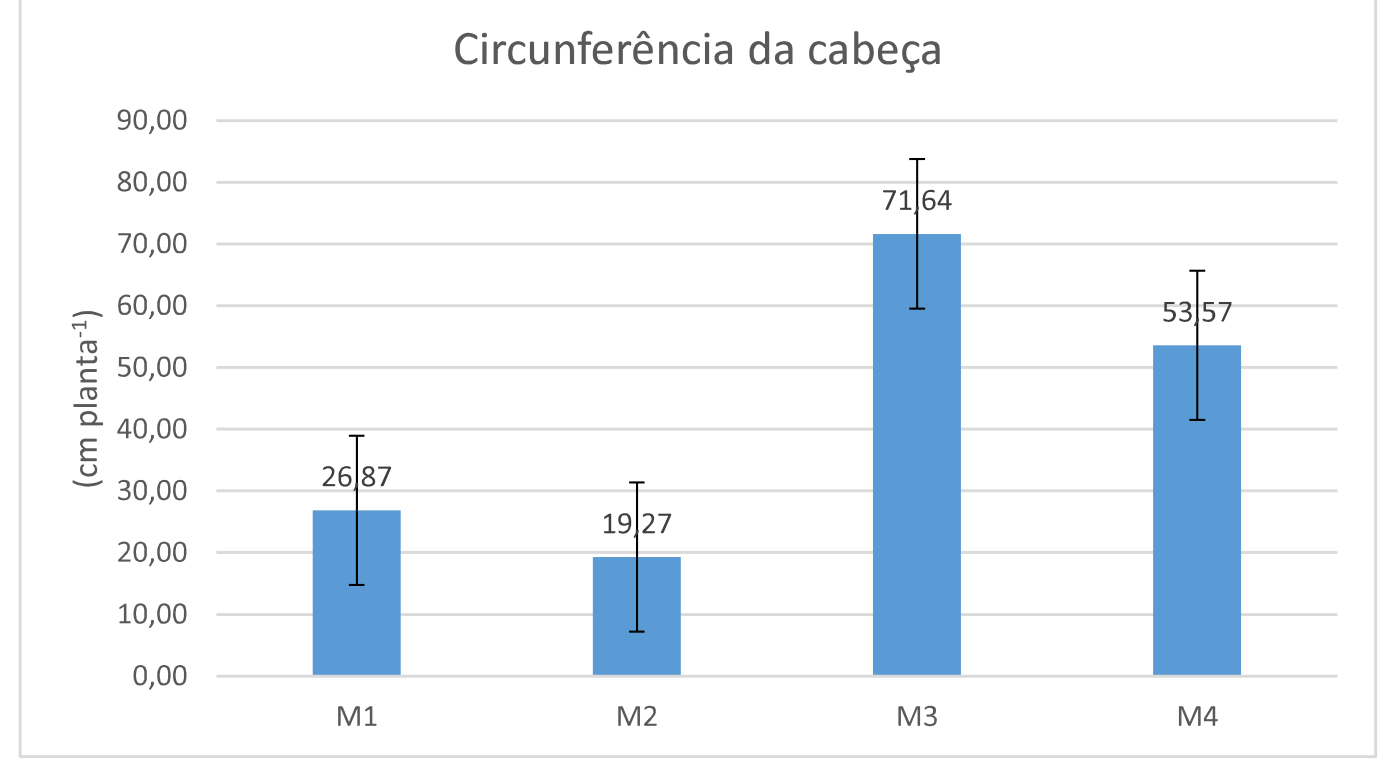

O valor médio de circunferência da cabeça foi de $71,64 \mathrm{~cm}$ para M3. Pode-se considerar que sob cultivo com M1 e M2 as cabeças não se desenvolveram suficientemente.

\section{Comprimento das folhas}

A medida das folhas foi feita nas folhas que apresentaram valores maiores que 5 $\mathrm{cm}$, e os resultados estão mostrados na Figura 4.14.

Figura 4.14 - Valores de comprimento da folha das alface sob cultivo de cada mistura.

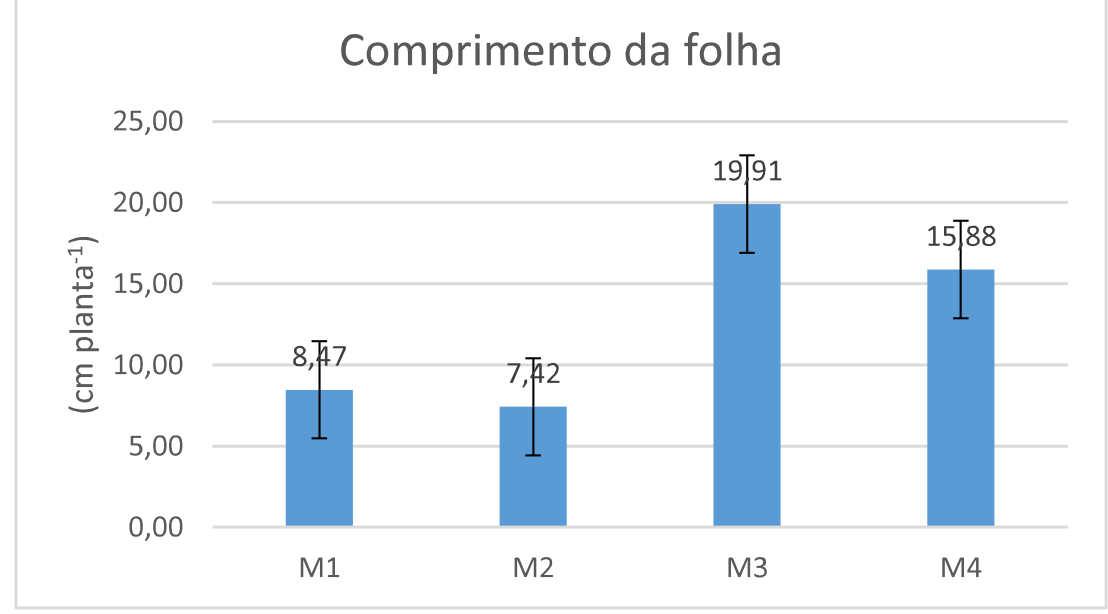


Como pode-se perceber, mais uma vez a M3 mostrou-se mais satisfatória em relação às outras misturas, atingindo folhas com valores médios de $19,91 \mathrm{~cm}$, enquanto que com M1 e M2 as folhas não atingiram comprimento médio maior que 9 $\mathrm{cm}$, sendo consideradas como não desenvolvidas.

\section{MSPA}

Assim como para a MFPA, a massa seca das alfaces (Figura 4.15) foi feita a fim de ver a perda de água ao longo da desidratação da folhas, e os resultados são os mesmos obtidos para os outros atributos, onde a M3 apresentou a maior massa seca da parte aérea, seguida da M4 > M1> M2.

Figura 4.15 - Valores de massa fresca da parte aérea das alfaces sob cultivo de cada mistura.

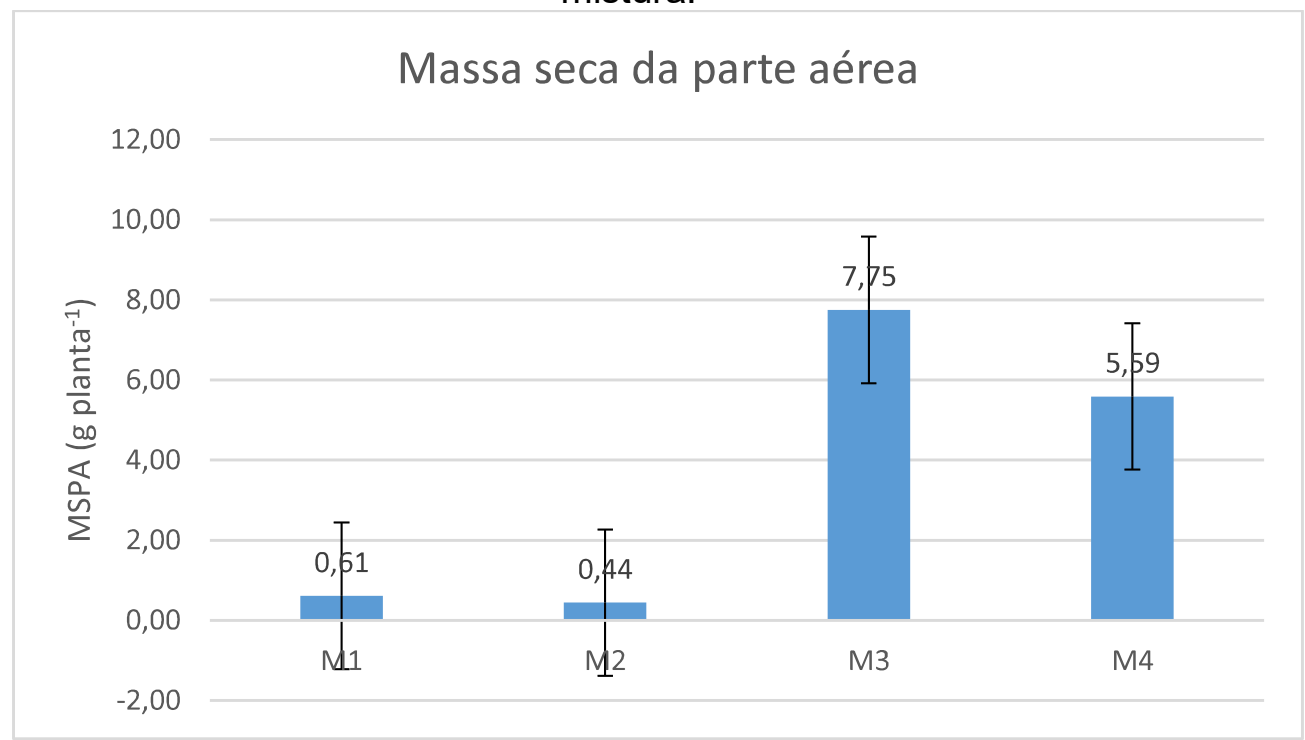

Para valores de MSPA, os valores encontrados para M3 e M4 estão de acordo ao encontrado por AZEVEDO et al. (2014), com valor médio de 8,13 $\mathrm{g} \mathrm{planta}^{-1}$.

\section{Número de folhas}

A contagem das folhas (Figura 4.16) foi feita até quando se conseguiu desmembrar a folha do caule sem danificá-la. 
Figura 4.16 - Número de folhas das alfaces sob cultivo de cada mistura no final do crescimento.

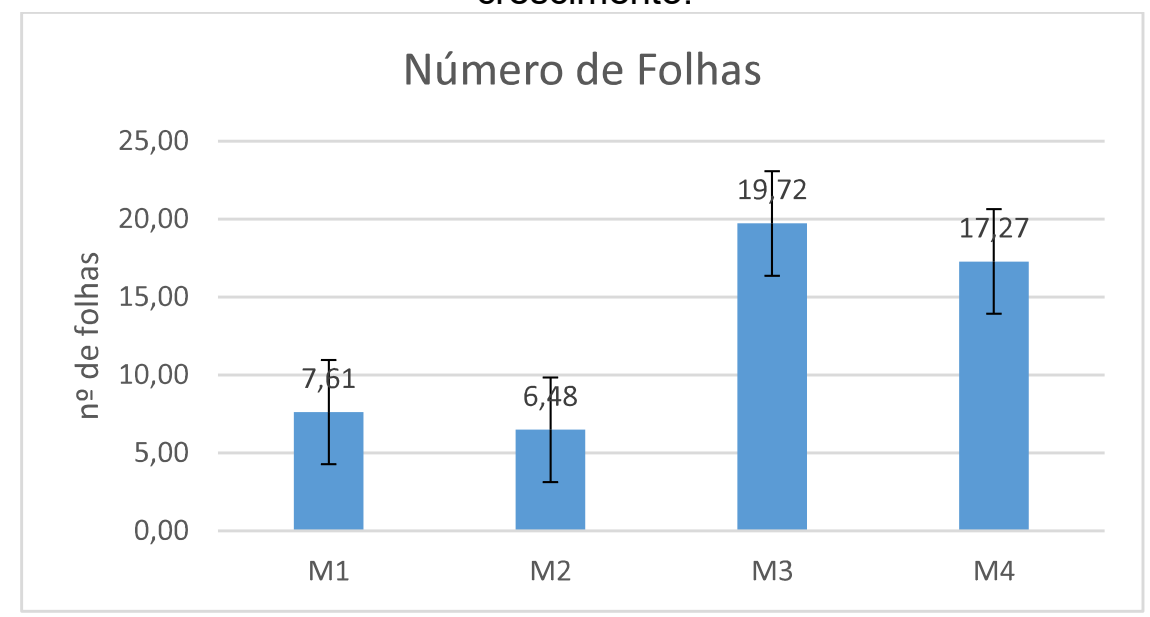

O que pode-se perceber mais uma vez foi uma tendência da mistura M3 apresentar os melhores resultados agronômicos, sendo os resíduos cama de frango em conjunto com o esterco bovino a melhor mistura para esse atributo.

Embora no trabalho de AZEVEDO et al. (2014) alguns cultivares chegaram a números de folhas superiores a 30 , a maioria dos valores encontrados para as outras cultivares foi próximo a 20 , sendo o mesmo valor encontrado no presente trabalho para M3.

\section{Altura do pé}

Com esse atributo é possível perceber facilmente qual mistura mostrou-se melhor agronomicamente, pois foi nítido o melhor desenvolvimento das alfaces sob o cultivo da M3 em comparação com as outras misturas, como pode-se perceber na Figura 4.17.

Figura 4.17 - Valores de altura do pé de alface sob cultivo de cada mistura.

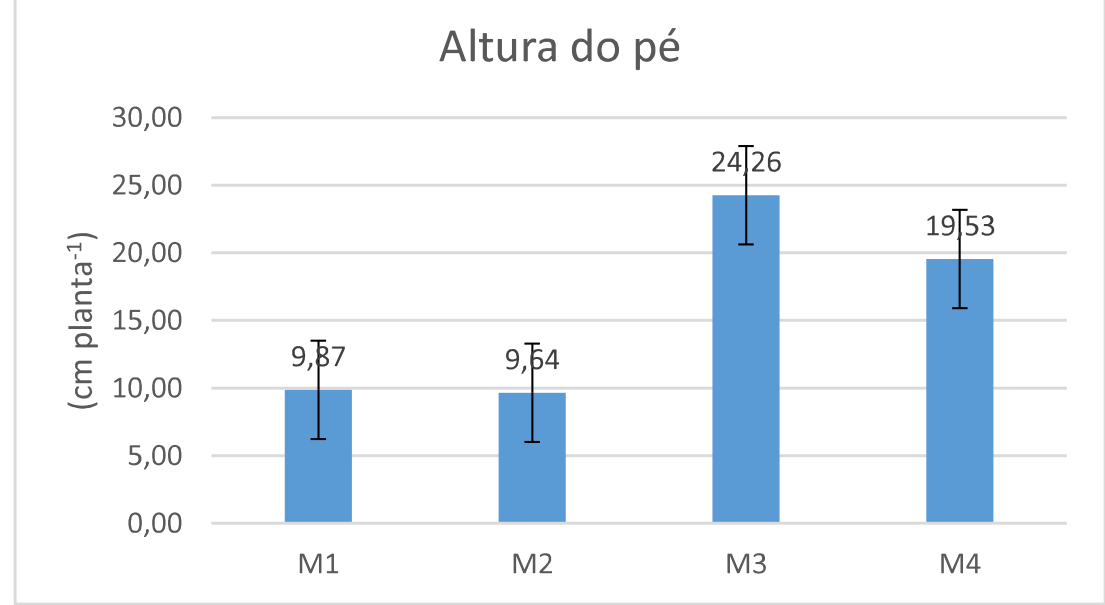


Como pode-se perceber, a M3 chegou a altura do pé próximo a $25 \mathrm{~cm}$, enquanto que M1 e M2 tiveram praticamente o mesmo desenvolvimento, chegando a altura do pé média de quase $10 \mathrm{~cm}$, sendo isso considerado um desenvolvimento pouco produtivo.

No trabalho de AZEVEDO et al. (2014), para todas os cultivares testados, o maior valor para altura do pé foi de $24 \mathrm{~cm}$, sendo esse valore próximo do encontrado no presente trabalho nas cabeças de alfaces sob M3. Pode-se considerar também a M4 como representativa, pois para a maioria dos cultivares no trabalho de AZEVEDO et al. (2014) os valores foram próximos a $20 \mathrm{~cm}$, mostrando que M3 e M4 estão de acordo com os trabalhos da literatura.

As cartas controle que comprovam que todos os dados, embora alguns equidistantes, estão dentro da faixa aceitável de valores serão mostradas no anexo II.

\subsection{Conclusões}

Umas das formas de se avaliar a eficiência de uma cultura são os atributos biométricos, em que se pode perceber visivelmente como uma cultura se desenvolveu ao longo de seu crescimento. Nessa etapa, é possível perceber os possíveis fatores negativos (patogenia, insetos, má formação etc.) como os positivos (plantas vistosas, com coloração exuberante, completa formação da espécie etc.).

Com este capítulo pode-se concluir que o biofertilizante onde se utilizou a mistura esterco bovino + cama de frango (M3) foi o que produziu os resultados mais satisfatórios quanto ao atributos biométricos (massa fresca da parte aérea, circunferência da cabeça, número de folhas, massa seca da parte aérea, comprimento da folha e altura do pé).

Pôde-se perceber também que para todas as misturas foi pequena a presença de microbiológicos, mostrando que embora as misturas tivessem como matéria-prima dejetos de animais, o produto final denominado biofertilizante não passou isso para as alfaces, mostrando que o processo fermentativo ajuda no controle microbiológico. Além disso, os biofertilizantes atuam como repelente dos insetos capazes de causar danos para as alfaces.

Em relação aos resíduos utilizados na pesquisa, não se aconselha o uso de bagaço de laranja na produção de biofertilizantes orgânicos, pois o mesmo apresenta propriedades ácidas que tornam o produto final menos nutritivo. 
Em suma, para todos os quesitos avaliados neste estudo, a M3 foi a melhor mistura desde o preparo dos biofertilizantes até a produtividade das alfaces hidropônicas. 

Capítulo V

\section{Aplicação da biomassa em cultivo de alface em vaso}





\section{RESUMO DO CAPÍTULO V}

MENDES, Leandro Antunes. Capítulo $V$ - Aplicação da biomassa em cultivo de alface em vaso. In: Avaliação das transformações químicas e do potencial agronômico de biofertilizantes líquidos produzidos a partir de resíduos agroindustriais para o manejo sustentável em agricultura orgânica. Tese (Doutorado em Química). Universidade de São Paulo, Instituto de Química de São Carlos, 2017. p. 95110.

Considerando a agricultura orgânica e seus princípios de comprometimento com a saúde, a cidadania e a ética, este trabalho buscou até o presente momento canalizar esforços para a melhoria dessas técnicas, por meio da aplicação de biofertilizantes. Deste modo, buscou-se comparar a eficiência do fertilizante comercial com a do biofertilizante produzido por meio da compostagem dos resíduos agroindustriais. Deste modo, aplicou-se a biomassa (porção nutritiva retida na peneira ao separar o biofertilizante, isto é, a parte líquida) de cada mistura, a saber: M1 (esterco bovino + bagaço de laranja), M2 (cama de frango + bagaço de laranja), M3 (esterco bovino + cama de frango) e M4 (esterco bovino + bagaço de laranja + cama de frango), de modo a avaliar quinzenalmente por 60 dias os atributos físico-químicos como acidez, concentração de macro e micronutrientes, teor de matéria orgânica e atributos de qualidade sanitária. Assim sendo, as biomassas foram aplicadas em vasos de alface cultivados em solo, em triplicata, bem como um tratamento que consiste apenas no uso de água e outro que se reduz a aplicação do fertilizante comercial (NPK). Passados 30 dias, foi avaliada a resposta de cada cultura correspondente a cada tratamento, baseando-se nos seguintes índices físicos: massa fresca, circunferência da cabeça, massa seca, número de folhas, altura do pé e tamanho da folha.

Assim, este projeto considera a importância tanto da porção sólida (biomassa) quanto a porção líquida (biofertilizantes) produzidas a partir de resíduos agroindustriais. 



\subsection{Materiais e Métodos}

5.1.1. Caracterização físico-química do solo e das biomassas (M1, M2, M3 e M4)

Neste capítulo, são apresentados os atributos físico-químicos do solo e do composto sólido (biomassa - material retido na peneira ao filtrar o biofertilizante) além dos atributos biométricos das alfaces quando este produto foi aplicado. O solo e a biomassa foram avaliados quanto a: acidez, carbono orgânico total, umidade, sólidos totais, sólidos fixos e nutrientes.

\subsubsection{Análise granulométrica do solo}

A fim de saber a granulometria do solo utilizado para esse estudo foi feita a análise granulométrica em laboratório especializado localizado no Departamento da Geotecnia da USP São Carlos. Os ensaios se basearam nas seguintes normas (ABNT, 2016):

ABNT NBR 6457, Amostras de solo - Preparação para ensaios de compactação e ensaios de caracterização.

ABNT NBR 6458:2016, Grãos de pedregulho retidos na peneira de abertura 4,8 mm - Determinação da massa específica, da massa específica aparente e da absorção de água.

ABNT NBR NM ISO 3310-1, Peneiras de ensaio - Requisitos técnicos e verificação Parte 1: Peneiras de ensaio com tela de tecido metálico.

ABNT NBR NM ISO 3310-2, Peneiras de ensaio - Requisitos técnicos e verificação Parte 2: Peneiras de ensaio de chapa metálica perfurada.

O ensaio granulométrico consiste em uma sequência de procedimentos que resulta em um gráfico, no qual se encontram nas abscissas os diâmetros das partículas em escala logarítmica e, nas ordenadas, a porcentagem das partículas retidas referentes aos diâmetros considerados em escala aritmética. Com isso, é possível inferir qual a proporção das partículas do solo (ABNT, 2016).

A qualidade do solo é fundamental para o funcionamento dos fertilizantes, dado que este regula a percolação de água e o enraizamento das plantas. 
5.1.3. Aplicação das biomassas nas alfaces sob cultivo em vasos

Após as caracterizações, as biomassas foram aplicadas nas alfaces nas seguintes proporções:

- 3 vasos tratados apenas com água, sem aplicação da biomassa;

- 3 vasos tratados com o fertilizante comercial NPK, sob a dosagem recomendada pelo fabricante para comparação;

- 3 vasos tratados com a biomassa resultante da mistura M1 com a dosagem agronômica de $76 \mathrm{~g} \mathrm{dm}^{-3}$ de solo;

- 3 vasos tratados com a biomassa resultante da mistura M1 com 1,5x a dosagem agronômica, isto é, $114 \mathrm{~g} \mathrm{dm}^{-3}$ de solo;

- 3 vasos tratados com a biomassa resultante da mistura M2 com a dosagem agronômica de $76 \mathrm{~g} \mathrm{dm}^{-3}$ de solo;

- 3 vasos tratados com a biomassa resultante da mistura M2 com 1,5x a dosagem agronômica, isto é, $114 \mathrm{~g} \mathrm{dm}^{-3}$ de solo;

- 3 vasos tratados com a biomassa resultante da mistura M3 com a dosagem agronômica de $76 \mathrm{~g} \mathrm{dm}^{-3}$ de solo;

- 3 vasos tratados com a biomassa resultante mistura M3 com 1,5x a dosagem agronômica, isto é, $114 \mathrm{~g} \mathrm{dm}^{-3}$ de solo;

- 3 vasos tratados com a biomassa resultante da mistura M4 com a dosagem agronômica de $76 \mathrm{~g} \mathrm{dm}^{-3}$ de solo;

- 3 vasos tratados com a biomassa resultante da mistura M4 com 1,5x a dosagem agronômica, isto é, $114 \mathrm{~g} \mathrm{dm}^{-3}$ de solo;

A Figura 5.1 mostra o esquema representativo da montagem dos vasos.

Figura 5.1 - Mudas das alfaces nos vasos com seus respectivos tratamentos de biomassa. 
Após 30 dias regando as alfaces diariamente com $150 \mathrm{~mL}$ de água foi feita a coleta (Figura 5.2) e caracterização quanto à matéria fresca da parte aérea, circunferência da cabeça, número de folhas, tamanho da folha e altura do pé. Após isso, as alfaces foram colocadas em estufa por $24 \mathrm{~h}$ a $65^{\circ} \mathrm{C}$, para caracterizar também quanto à matéria seca da parte aérea

Figura 5. 2 - Coleta das alfaces após 30 dias

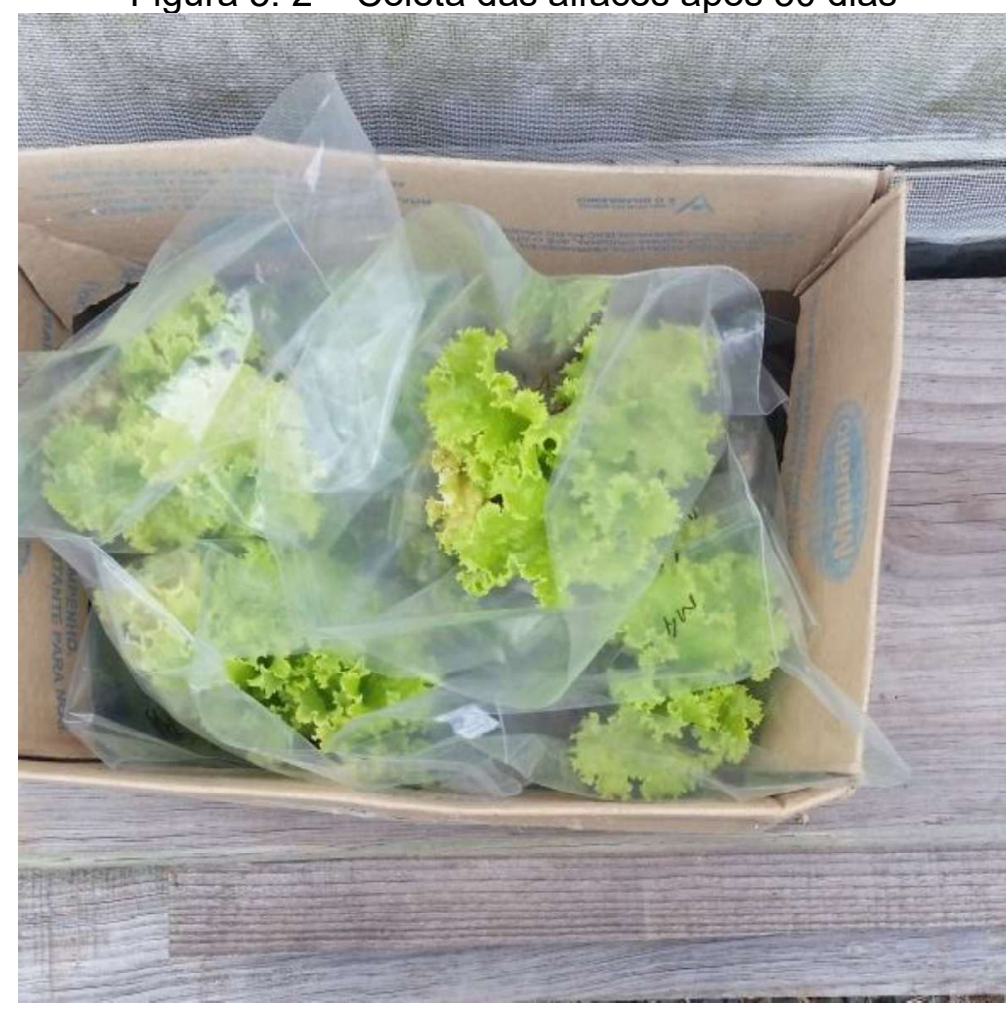

\subsubsection{Avaliação biométrica das alfaces}

Após os 30 dias de cultivo, as alfaces foram submetidas à análise biométrica. Os procedimentos adotados foram os mesmos descritos no item 4.1.7 do Capítulo IV para os atributos: matéria fresca da parte aérea (MFPA), circunferência da cabeça, número de folhas, massa seca da parte aérea (MSPA), comprimento da folha e altura do pé.

\subsection{Resultados e discussão}

\subsubsection{Análises físico-químicas do solo e das biomassas}

Para o acúmulo de maior massa de biomassa, toda a parte sólida resultante da filtragem de cada mistura foi coletada para a avaliação das características físicoquímicas do trabalho. 
A Tabela 5.1 mostra os resultados obtidos para cada amostra.

Tabela 5. 1 - Valores das análises físico-química do solo e das biomassas.

Amostra

$$
\mathrm{pH}
$$

Sólidos totais (mg kg-1)

$\begin{array}{cccccc}\text { Solo } & 5,62 & 991.100 & 1,48 & 0,24 & 0,89 \\ \text { Biomassa M1 } & 7,60 & 269.204 & 66,25 & 43,19 & 73,08 \\ \text { Biomassa M2 } & 4,84 & 182.583 & 80,52 & 42,79 & 81,74 \\ \text { Biomassa M3 } & 6,34 & 418.597 & 55,12 & 61,75 & 58,14 \\ \text { Biomassa M4 } & 6,56 & 536.992 & 45,08 & 57,92 & 46,30\end{array}$

Como pode-se observar, apenas a M2 (cama de frango + bagaço de laranja) é ácida, mostrando que a característica ácida do resíduo bagaço de laranja não foi corrigida no processo fermentativo, deixando o produto final ácido. Para M1 (esterco bovino + bagaço de laranja), apesar do bagaço de laranja também estar presente, isso não ocorreu, indicando que o esterco bovino auxilia no processo fermentativo de forma a neutralizar o produto. Logo, M1, M2 e M3 atingiram valores de $\mathrm{pH}$ ideais para a cultura de alface. $\mathrm{O}$ solo escolhido apresentava-se ligeiramente ácido, mas com a aplicação das misturas com valores de pH próximos ao neutro, isso foi corrigido.

Para os valores de porcentagem de matéria orgânica (\%MO), o maior valor obtido foi para a M2, mostrando que os resíduos utilizados, em especial a cama de frango, apresenta grande quantidade de $\mathrm{MO}$, devido à grande quantidade de resíduos presentes no mesmo (penas, esterco de aves, ração etc.).

Quando se compara a porcentagem de carbono orgânico total (\%COT) com a $\% \mathrm{MO}$, um resultado curioso foi encontrado. Teoricamente, espera-se que amostras com maiores teores de matéria orgânica apresentem maiores teores de COT, mas no presente estudo isso não ocorreu. Pode-se observar que o maior valor para \%MO foi para a M2, mas essa não apresentou os maiores valores de \%COT, mostrando que nem toda matéria orgânica presente nessa mistura está ativa na forma de carbono orgânico. $\mathrm{O}$ maior resultado de \%COT foi para a $\mathrm{M} 3$, mistura esta que também apresentou os melhores resultados na aplicação dos biofertilizantes em alfaces sob cultivo hidropônico, resultados mostrados no Capítulo IV.

Vale lembrar que a \%COT está diretamente ligada ao valor agronômico de um produto, ou seja, quanto maior o teor de carbono orgânico total, melhores resultados agronômicos em se tratando de nutrientes são esperados. 


\section{- Nutrientes}

Foram feitas análises de nitrogênio e fósforo das biomassas. Os resultados estão mostrados Tabela 5.2 e 5.3 e nas Figuras 5.3 e 5.4 .

Tabela 5. 2 - Avaliação da concentração de NKT (em mg L-1) nas biomassas

\begin{tabular}{cc}
\hline Amostra & Teor de nitrogênio $\left(\mathrm{mg} \mathrm{L}^{-1}\right)$ \\
\hline M1 & 272,08 \\
M2 & 653,75 \\
M3 & 839,16 \\
M4 & 594,58 \\
\hline
\end{tabular}

Figura 5. 3 - Comportamento da concentração de NKT (em mg L-1) nos biomassas.

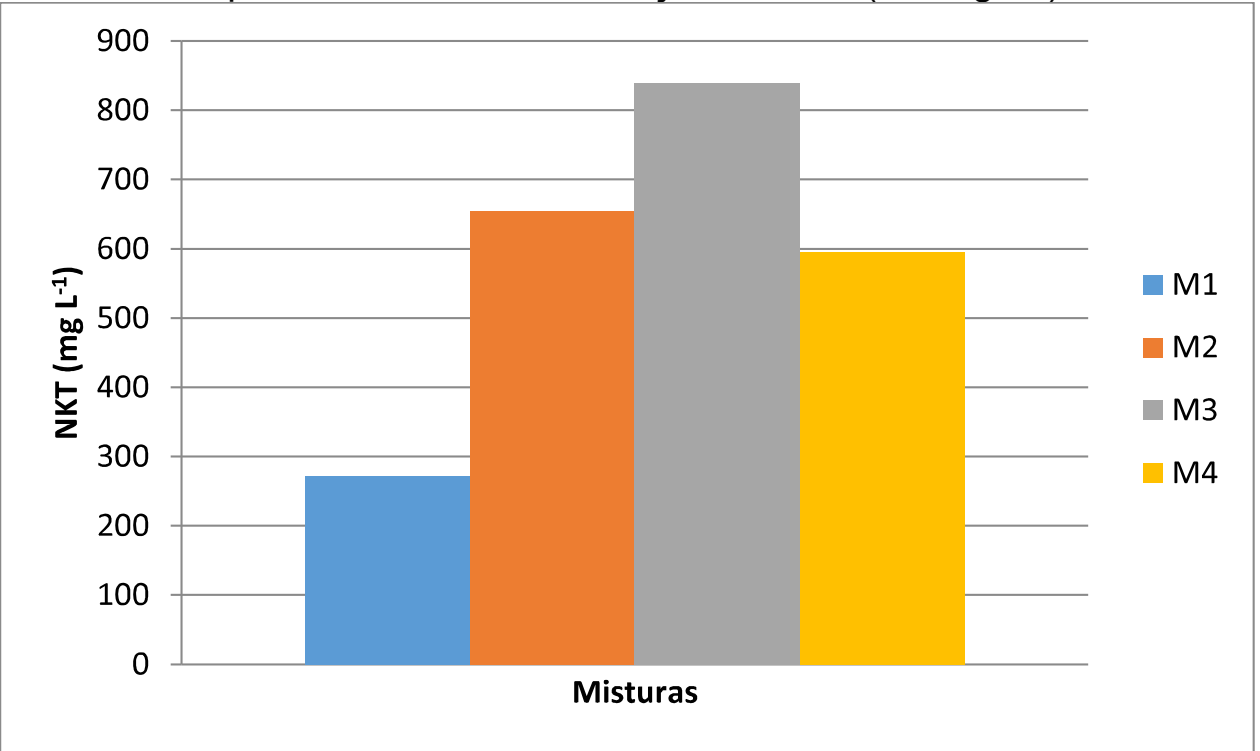

Pela avaliação dos resultados apresentados na Tabelas 5.2 e na Figura 5.3, pode-se notar que M3 apresenta maior concentração de nitrogênio, sendo esse resultado replicado nas análises de nitrogênio dos biofertilizantes, em que M3 apresentou a maior concentração de nitrogênio.

Tabela 5. 3 - Avaliação da concentração de fósforo na forma de fosfato (em mg L-1) nos biomassas.

\begin{tabular}{cc}
\hline Amostra & Teor de fosfato $\left(\mathrm{mg} \mathrm{L}^{-1}\right)$ \\
\hline M1 & 27,84 \\
M2 & 30,15 \\
M3 & 28,83 \\
M4 & 28,65 \\
\hline
\end{tabular}


Figura 5.4 - Comportamento da concentração de fósforo (em $\mathrm{mg} \mathrm{L}^{-1}$ ) nas biomassas

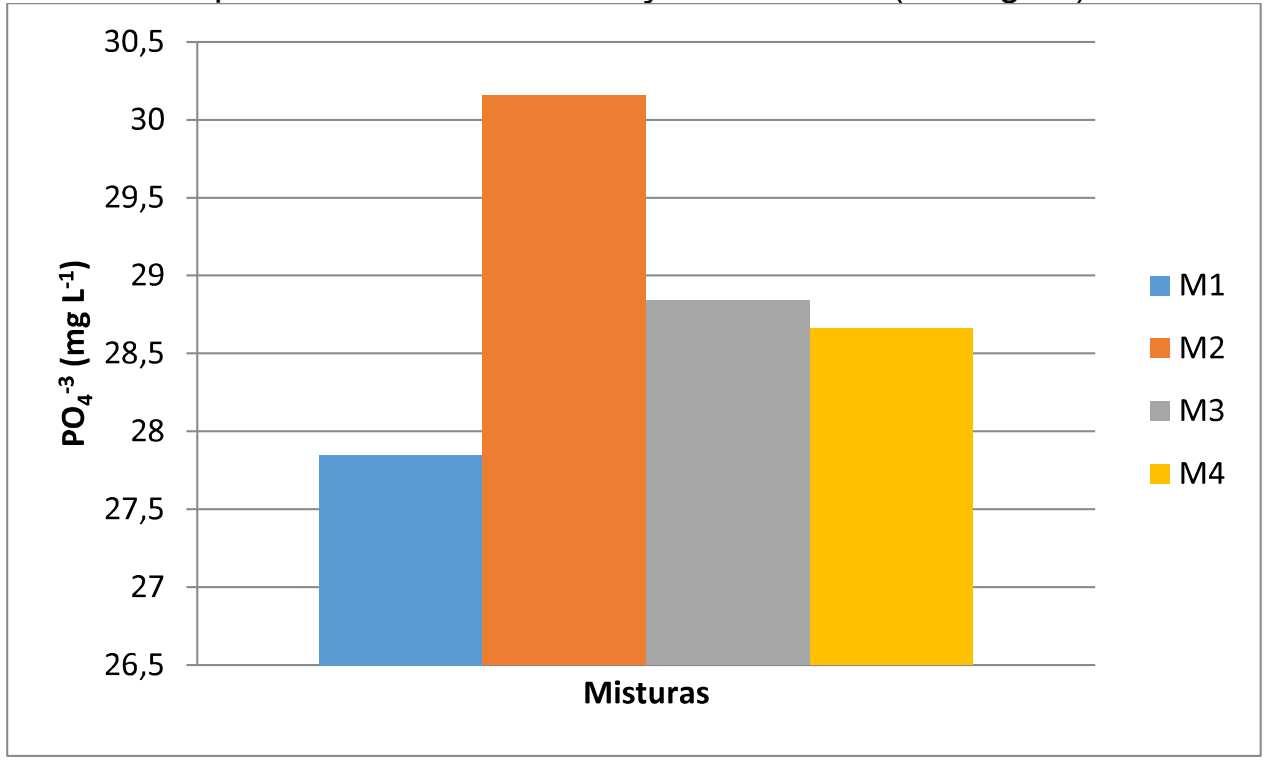

Quanto ao teor de fósforo, a mistura M2 apresentou o maior valor em relação às outras.

\subsubsection{Análise granulométrica do solo}

Na Figura 5.5 está mostrada a curva de distribuição granulométrica do solo utilizado no presente estudo.

Figura 5. 5 - Curva de distribuição granulométrica do solo.

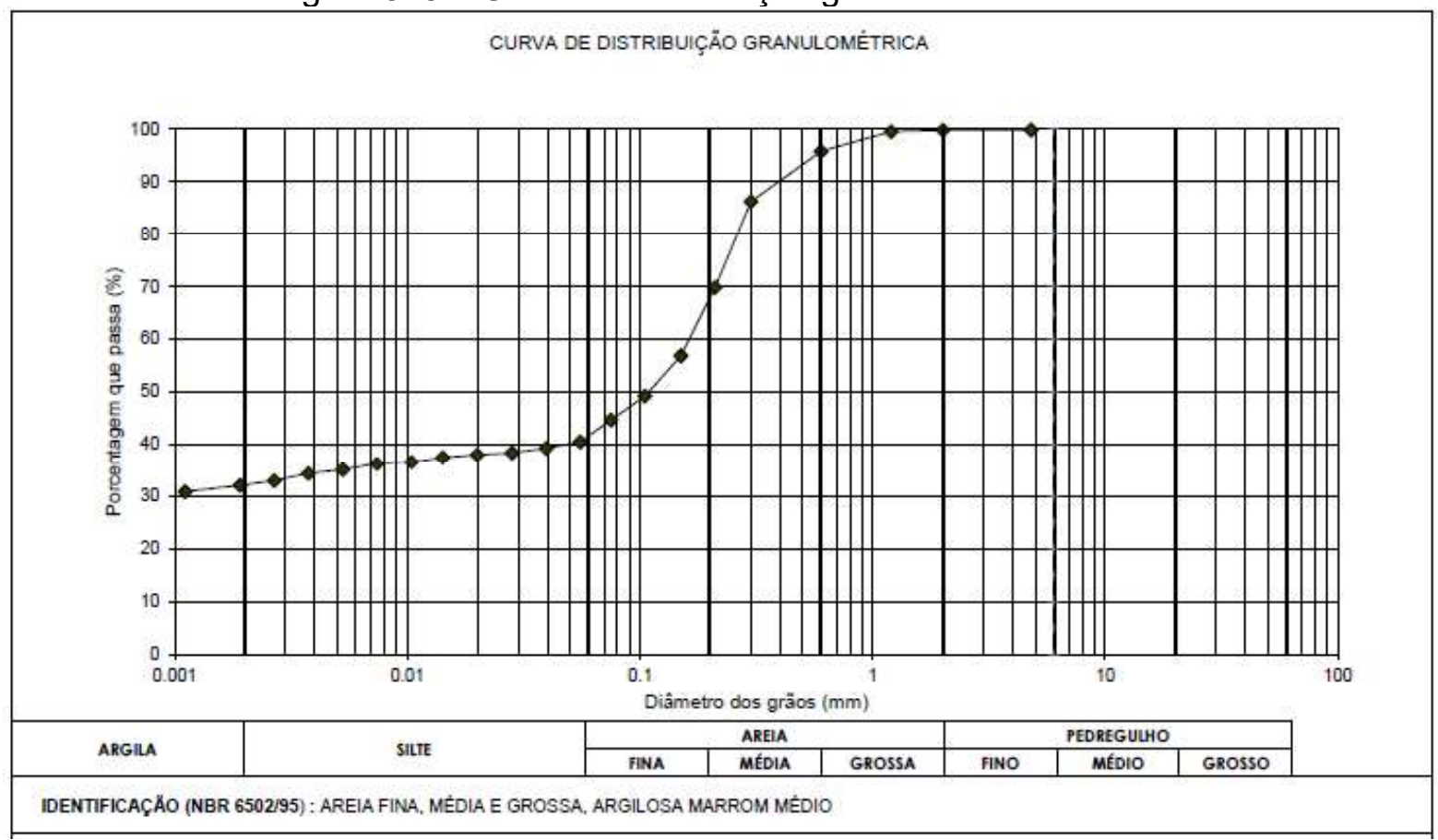

Como pode-se observar pela curva de distribuição granulométrica, o solo foi definido como areia fina, média e grossa, argilosa marrom médio. A determinação da 104 
participação em massa dos diferentes tamanhos das partículas nos dá a composição textural do solo. O tamanho das partículas a que se refere cada fração textural é definido conforme o aspecto funcional da partícula, sendo assim, uma partícula mais grosseira (maior diâmetro) apresenta um comportamento muito diferente de uma partícula mais fina.

A Sociedade Brasileira de Ciências do Solo adota as seguintes dimensões para cada partícula: argila $(<0,002 \mathrm{~mm})$, silte $(0,002$ a $0,006 \mathrm{~mm})$, areia $(0,006$ a $2 \mathrm{~mm})$ e pedregulho (> $2 \mathrm{~mm}$ ). Pelo gráfico pode-se observar que o solo utilizado no presente estudo apresenta a seguinte porcentagem de cada grão, conforme apresentado na Tabela 5.4.

Tabela 5.4 - Composição dos grãos dos solos estudados.

\begin{tabular}{cc}
\hline Composição & Solo Argiloso (\%) \\
\hline Argila & 35,0 \\
Silte & 5,5 \\
Areia & 59,3 \\
Pedregulho & 0,2 \\
\hline
\end{tabular}

Pode-se perceber que o solo apresenta uma maior quantidade de areia, isso significa que esse solo tem baixa retenção de umidade, agregação, superfície específica e capacidade de troca catiônica. Isso pode ser comprovado com o resultado de \%MO mostrado na Tabela 5.1, onde o solo em questão apresentou apenas 1,48\% de matéria orgânica, relacionada ao teor de argila. Com isso, pode-se dizer que a aplicação das biomassas incrementa o teor de MO.

\subsubsection{Avaliação biométrica das alfaces}

A Tabela 5.5 mostra os valores obtidos para cada atributo biométrico avaliado. 
Tabela 5.5 - Avaliação do comportamento das alfaces tendo em vista o tratamento empregado

\begin{tabular}{|c|c|c|c|c|c|c|}
\hline $\begin{array}{l}\text { Tratamento } \\
\text { empregado }\end{array}$ & $\begin{array}{c}\text { Massa } \\
\text { fresca }(g \\
\left.\text { planta }^{-1}\right)\end{array}$ & $\begin{array}{l}\text { Circunferência } \\
\text { da cabeça }(\mathrm{cm})\end{array}$ & $\begin{array}{l}\text { Altura do } \\
\text { pé (cm) }\end{array}$ & $\begin{array}{l}\text { Tamanho } \\
\text { da folha } \\
\text { (cm) }\end{array}$ & $\begin{array}{c}\text { Massa } \\
\text { seca }(g \\
\left.\text { planta }^{-1}\right)\end{array}$ & $\begin{array}{c}\text { Número } \\
\text { de } \\
\text { folhas } \\
\text { (folhas }^{\text {planta }}{ }^{-1} \text { ) }\end{array}$ \\
\hline$M 1(1 X)$ & $6,72 \pm 2,03$ & $20,43 \pm 0,42$ & $8,17 \pm 1,25$ & $6,47 \pm 0,78$ & $7,56 \pm 0,22$ & $8 \pm 1$ \\
\hline$M 1(1,5 X)$ & $14,83 \pm 3,90$ & $23,33 \pm 3,09$ & $10,33 \pm 0,85$ & $8,3 \pm 1,55$ & $8,3 \pm 0,49$ & $8 \pm 0,82$ \\
\hline M2 (1X) & $8,33 \pm 4,37$ & $18,33 \pm 1,25$ & $8,17 \pm 0,47$ & $7,6 \pm 0,94$ & $7,6 \pm 0,48$ & $7 \pm 0$ \\
\hline$M 2(1,5 X)$ & $5,72 \pm 2,05$ & $17,87 \pm 2,26$ & $7,17 \pm 1,65$ & $7,32 \pm 1,87$ & $7,32 \pm 0,34$ & $6 \pm 1$ \\
\hline M3 (1x) & $18,83 \pm 2,45$ & $24,00 \pm 1,41$ & $13 \pm 0,81$ & $11,07 \pm 0,89$ & $6,67 \pm 0,14$ & $5 \pm 0$ \\
\hline$M 3(1,5 x)$ & $19,68 \pm 2,24$ & $25,70 \pm 0,29$ & $11,16 \pm 0,62$ & $10,67 \pm 1,03$ & $7,04 \pm 0,06$ & $6 \pm 0$ \\
\hline$M 4(1 x)$ & $15,95 \pm 0,47$ & $25,30 \pm 1,02$ & $10,67 \pm 1,03$ & $9,96 \pm 0,68$ & $5,49 \pm 0,13$ & $6 \pm 0$ \\
\hline$M 4(1,5 x)$ & $19,53 \pm 2,06$ & $25,90 \pm 0,37$ & $13,67 \pm 0,62$ & $9,83 \pm 0,62$ & $7,97 \pm 0,07$ & $7 \pm 0$ \\
\hline $\begin{array}{l}\text { Somente } \\
\text { água }\end{array}$ & $13,83 \pm 0,55$ & $21,43 \pm 1,14$ & $10,20 \pm 0,91$ & $9,13 \pm 0,90$ & $5,52 \pm 0,58$ & $5 \pm 1$ \\
\hline $\begin{array}{l}\text { Fertilizante } \\
\text { comercial }\end{array}$ & $17,33 \pm 2,04$ & $24,60 \pm 0,43$ & $12,60 \pm 0,37$ & $10,64 \pm 1,18$ & $6,38 \pm 0,55$ & $7 \pm 0$ \\
\hline
\end{tabular}

A dose recomendada pelo Ministério da Agricultura, Pecuária e Abastecimento (MAPA) é de $76 \mathrm{~g} \mathrm{dm}^{-3}$.

Para facilitar a visualização dos resultados, apresentam-se as Figuras 5.6-5.11.

Figura 5.6 - Avaliação do teor de massa fresca em cada tratamento.

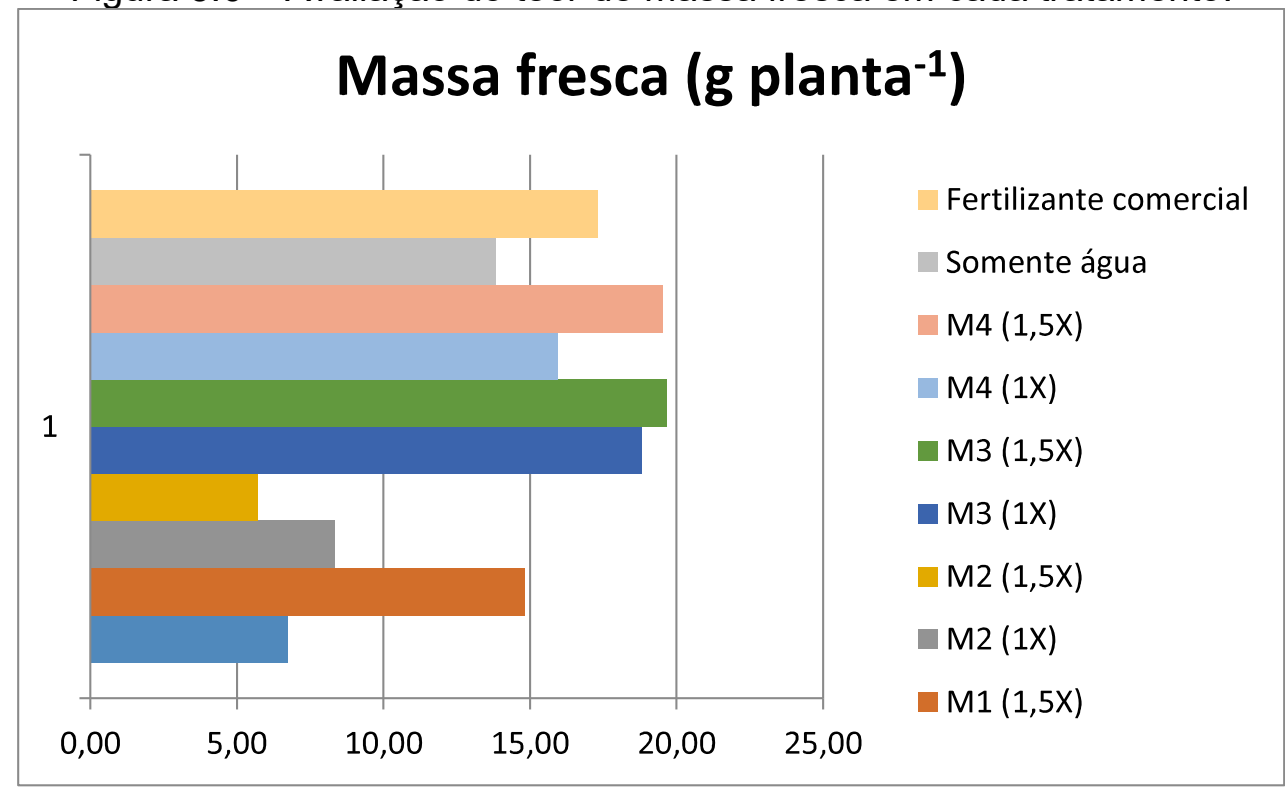

A Figura 5.6 revela que os tratamentos com biomassas M3 e M4 e fertilizante comercial (NPK) se encontram acima da média. Há destaque para a alta quantidade 
de massa fresca em M3 (1,5x) e M4 (1,5x), e para a baixa quantidade de massa fresca no tratamento com M1 (1x) e com o M2 (1,5x).

Figura 5. 7- Avaliação da circunferência da cabeça em cada tratamento

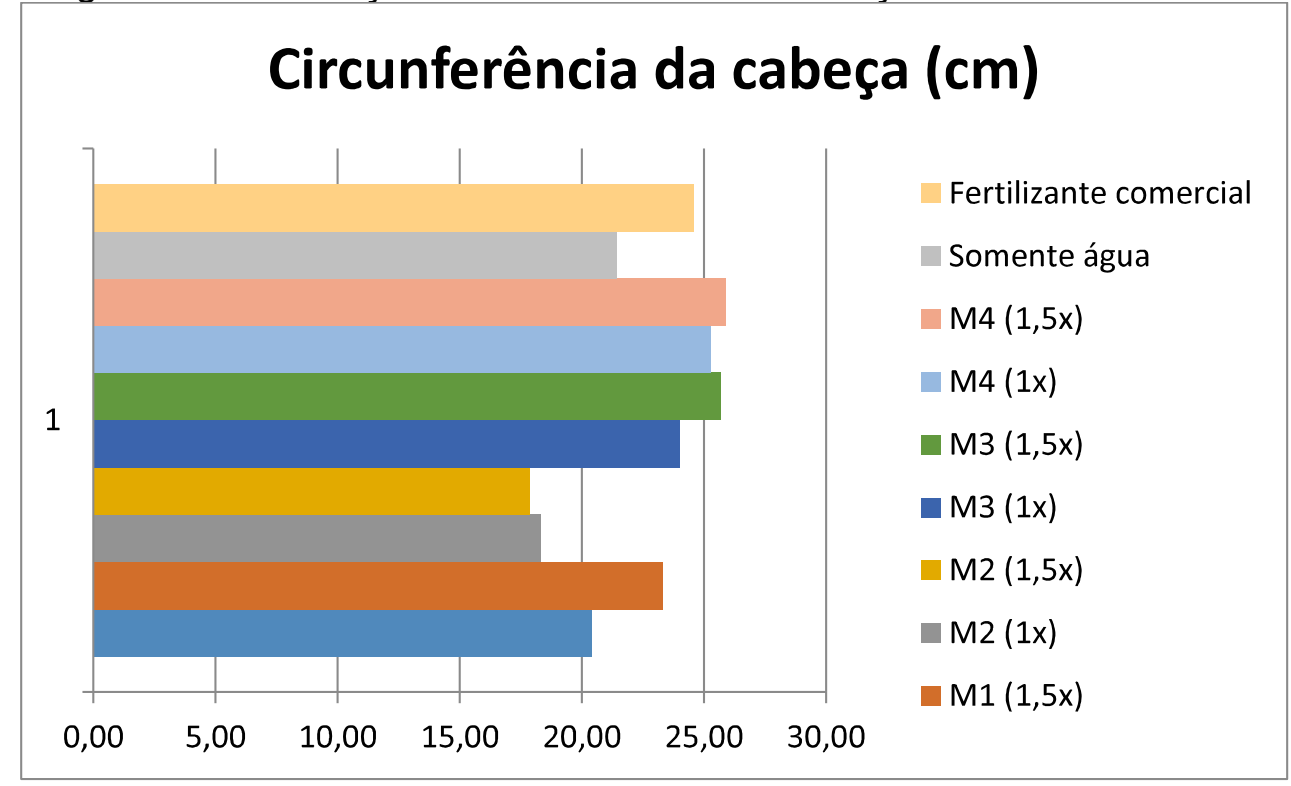

A Figura 5.7 releva que os tratamentos com biomassa e fertilizante comercial se encontram acima da média. Há destaque para a elevada circunferência da cabeça em M3 $(1,5 x)$ E M4 $(1,5 x)$, e para a reduzida circunferência da cabeça no tratamento que levou M2 (1,5x).

Figura 5.8 - Avaliação do tamanho do pé de alface em cada tratamento.

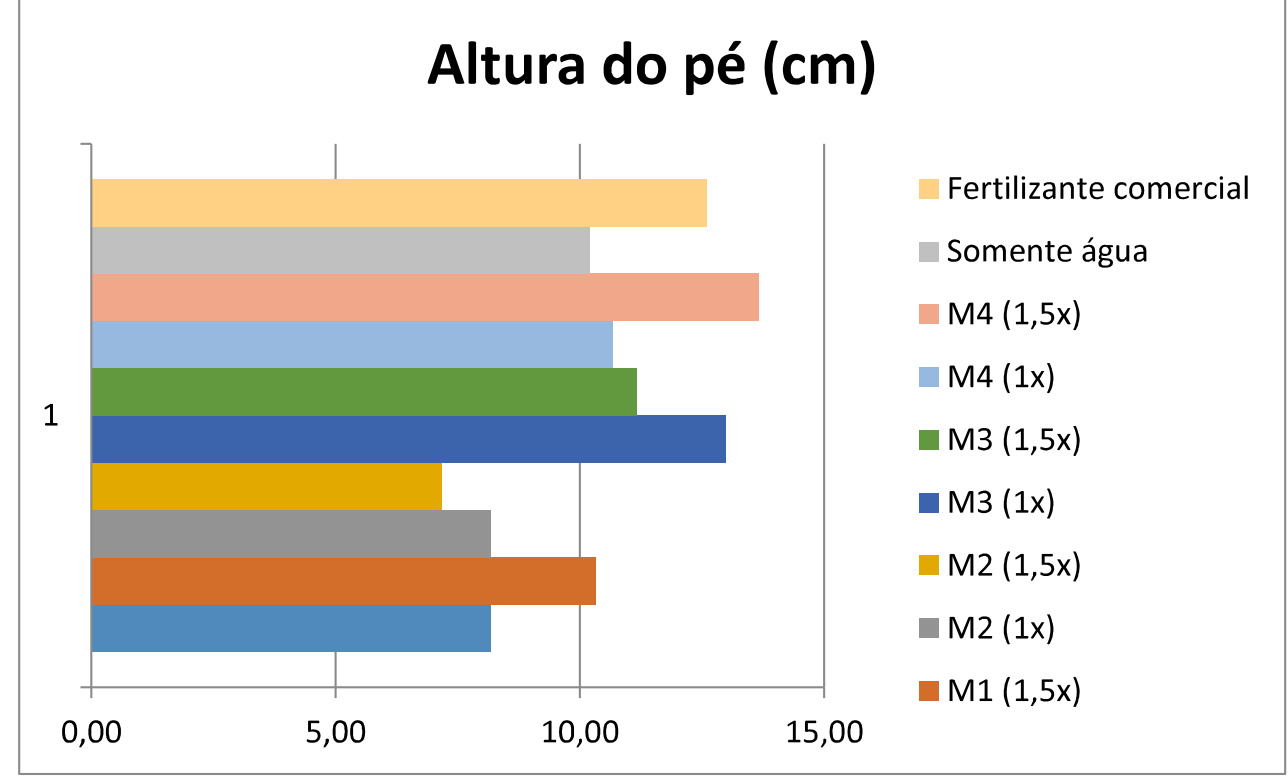

Na Figura 5.8, observa-se que, assim como nos anteriores, o fertilizante comercial e a biomassa M4 se destacaram positivamente. É válido salientar que M3 
(1x) e M4 (1,5x) se destacaram pela elevada altura do pé e o tratamento que empregou apenas água e com M2 $(1,5 \mathrm{x})$ se destacou pela reduzida altura do pé.

Figura 5. 9 - Avaliação do tamanho da folha em cada tratamento.

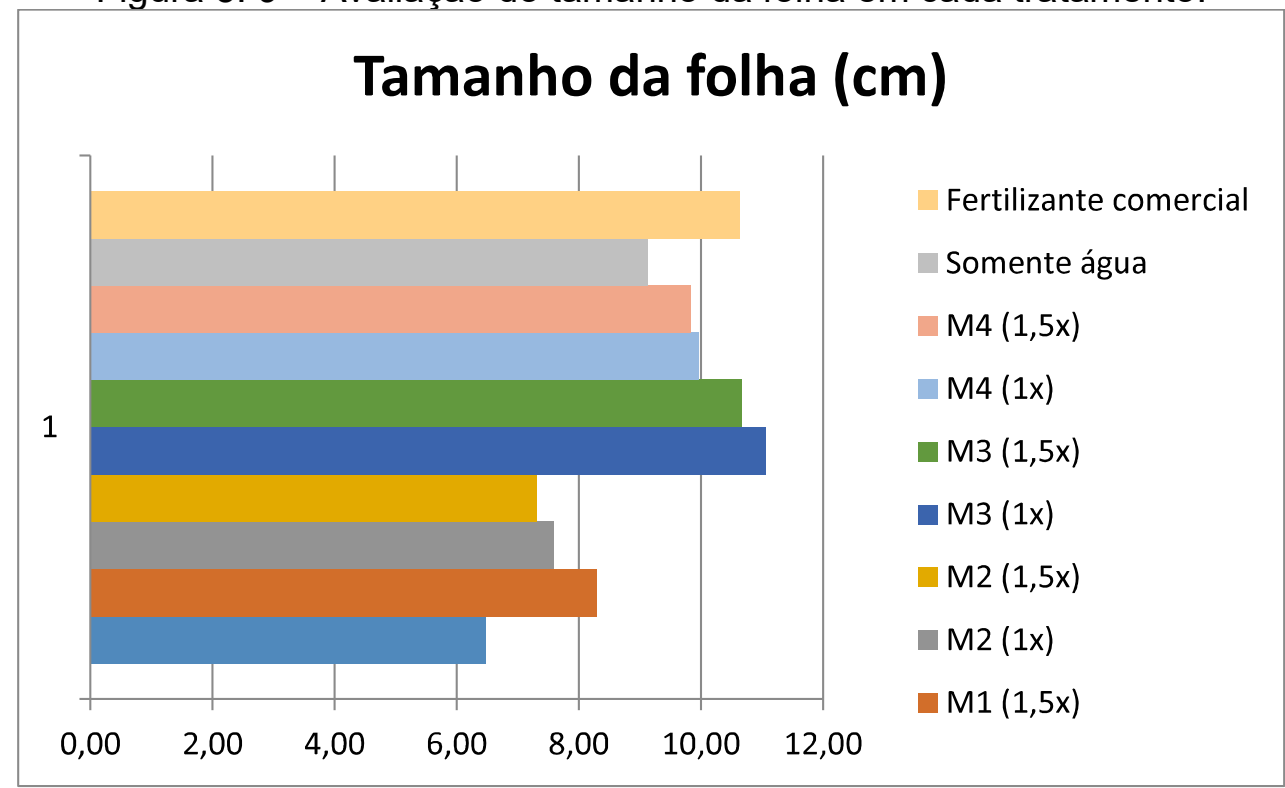

Pela Figura 5.9, é possível inferir que as biomassas M3 e M4 e o fertilizante comercial se mostraram acima da média neste aspecto. Neste sentido, o fertilizante comercial e a M3 (1x) apresentaram resultados elevados quanto ao tamanho da folha, e o tratamento com M2 (1,5x) e M1 (1x) apresentaram resultado inferior.

Figura 5. 10 - Avaliação do teor de massa seca em cada tratamento.

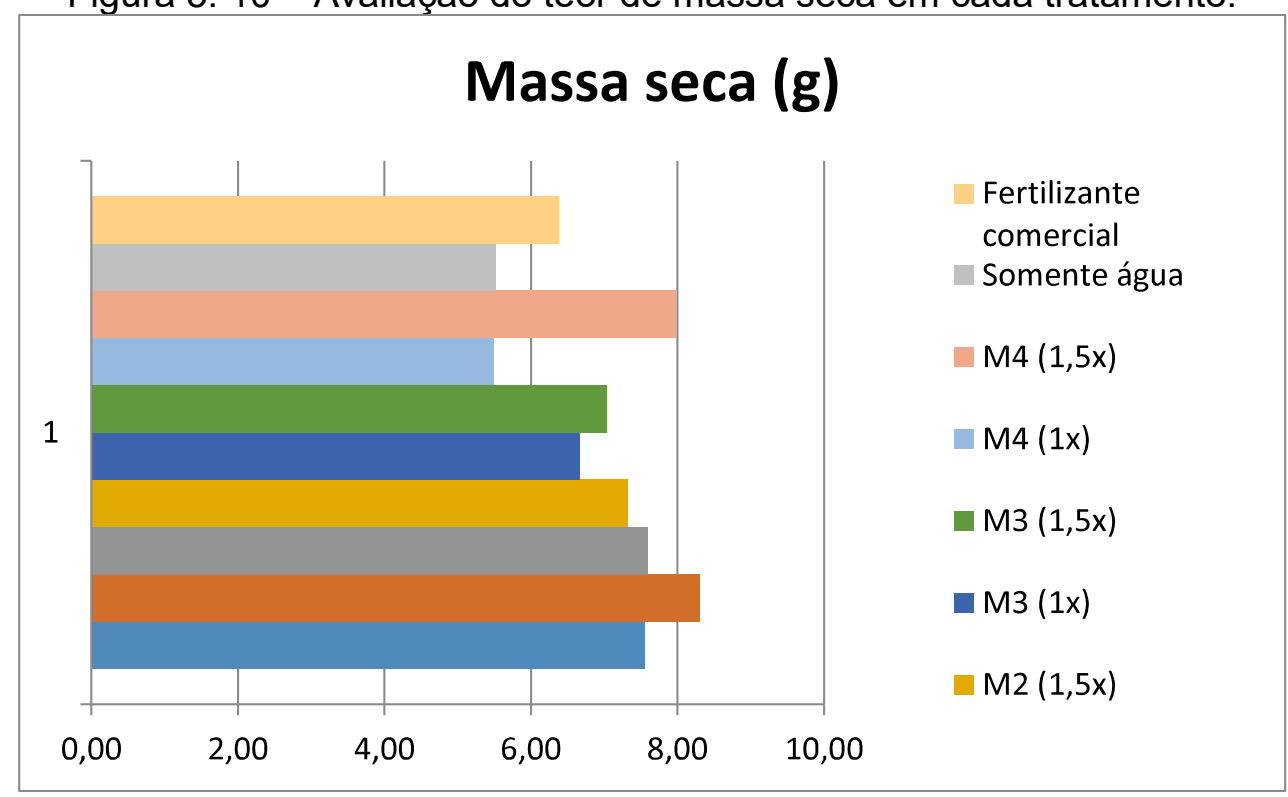

Por meio da Figura 5.10, pode-se inferir que há elevada quantidade de massa seca de M1 $(1,5 x)$ e M4 $(1,5 x)$ e para a baixa massa seca dos tratamentos que levam M4 (1x) e somente água. 
Figura 5. 11 - Avaliação do número de folhas em cada tratamento

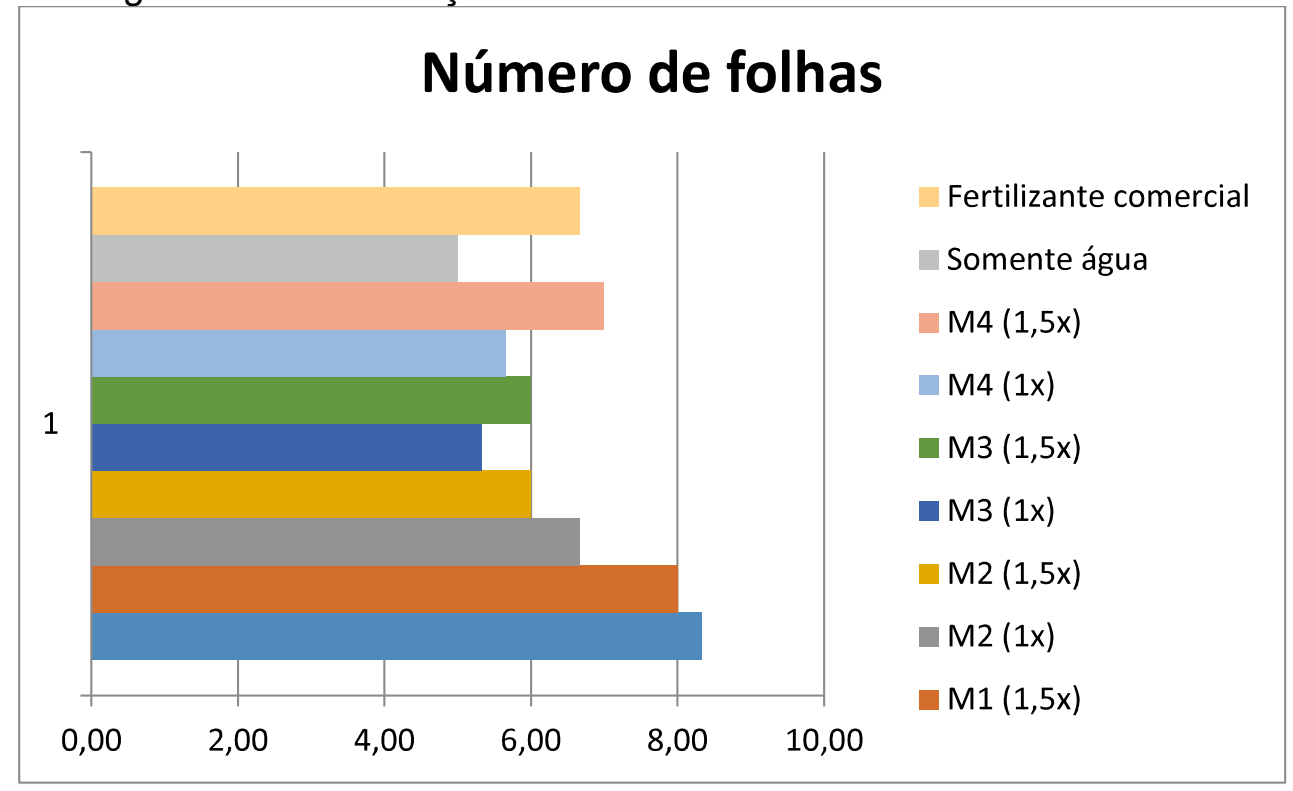

Por meio da Figura 5.11, pode-se afirmar que o tratamento com M1 apresentou maior sucesso em relação ao número de folhas, com as duas dosagens (1,0 e 1,5x), enquanto que o M3 (1x) apresentou menor quantidade de número de folhas.

\subsection{Conclusões}

Assim sendo, dentre as biomassas geradas e considerando os índices de comparação utilizados, pode-se inferir que a M4 $(1,5 x)$ foi mais eficiente em quase todos os aspectos, o que demonstra sua qualidade diante das outros.

A partir das Figuras apresentadas, portanto, é possível inferir que o fertilizante comercial e a M4 levaram a resultados muito semelhantes e positivos, em detrimento do que foi tratado apenas com água. Tal resultado é muito satisfatório, pois propõe que a biomassa, além de mais econômica, apresenta resultados semelhantes. 

Capítulo VI

Conclusão Geral 

O efeito dos biofertilizantes e das biomassas produzidas pela mistura dos resíduos orgânicos foram testados nas culturas de alface. Os biofertilizantes sob cultivo hidropônico e as biomassas sob cultivo convencional em solo.

Os biofertilizantes foram caracterizados quanto ao seu potencial agronômico e parâmetros de qualidade sanitária.

Com os resultados aqui obtidos, pode-se afirmar que os atributos dos biofertilizantes produzidos por todas as misturas estão de acordo com o Ministério da Agricultura, Pecuária e Abastecimento, o qual somente exige a especificação das propriedades em caso de produto comercial.

Pode-se afirmar, também, graças aos resultados biométricos das alfaces cultivadas sob cultivo hidropônico e em vaso, que os biofertilizantes contribuíram de forma positiva para a produtividade da cultura em foco e que os fertilizantes inorgânicos podem ser substituídos pelos propostos no trabalho em questão.

O biofertilizante que melhor potencial agronômico demonstrou foi o que, quando aplicado à cultura, produziu as alfaces que obtiveram os melhores resultados biométricos. A mistura M3 produziu o melhor biofertilizante no tocante ao potencial agronômico.

Quando se comparam os espectros dos ácidos húmicos extraídos, notamos bandas com maior intensidade para $\mathrm{M} 3$, mostrando ser essa a mistura em que a humificação da matéria orgânica se mostrou mais presente, sendo esse um indicativo de que essa mistura apresenta melhores resultados agronômicos em relação às outras.

Os resultados obtidos no exterior foram de grande valia para o projeto, uma vez que com essas caracterizações avaliaram-se os nutrientes capazes de melhorar a fertilidade do meio em questão. Além disso, o aprendizado acerca das extrações de frações orgânicas do solo foi de fundamental importância um maior fracionamento do solo. 


\section{REFERÊNCIAS BIBLIOGRÁFICAS}

ALVES, G. S., SANTOS, D., SILVA, J. A., NASCIMENTO, J. A. M., CAVALCANTE, L. F., DANTAS, T. A. G. Estado nutricional do pimentão cultivado em solo tratado com diferentes tipos de biofertilizantes. Acta Science Agronomy, v. 31, n. 4, p. 661-665, 2009.

AMALFITANO, C.; PIGNALOSA, V.; AURIEMMA, L.; RAMUNNI, A. The contribution of lignin to the composition of humic acids from a wheat-straw amended soil during 3 years of incubation in pots. The Journal of Soil Science, v. 43, p. 495-504, 2002.

ARAÚJO, E. N., OlIVEIRA, A. P., CAVALCANTE, L. F., PEREIRA, W. E., BRITO, N. M., NEVES, C. M., SILVA, E. E. Produção do pimentão adubado com esterco bovino e biofertilizante. Revista Brasileira de Engenharia Agrícola e Ambiental, v. 11, n. 5, p. 466470, 2007.

ARAÚJO, J. B. S.; CARVALHO, G. J.; GUIMARÃES, R. J.; MORAIS, A. R.; CUNHA, R. L. Composto orgânico e biofertilizante supermagro na formação de cafeeiros. Coffee Science, v. 3, n. 2, p. 115-123, 2008.

ASGHAR, H.N.; ISHAQ, M.; ZAHIR, Z.A.; KHALID, M.; ARSHAD, M. Response of radish to integrated use of nitrogen fertilizer and recycled organic waste. Pakistan Journal of Botany. v. 38, n. 3, p. 691-700, 2006.

ASSOCIAÇÃO BRASILEIRA DE NORMAS TÉCNICAS. NBR 7181: solo - análise granulométrica. 2. ed. Rio de Janeiro: ABNT, 2016. 16 p.

AZEVEDO, A. M.; ANDRADE, JUNIOR, V. C. de; CASTRO, B. M. de C. e; OLIVEIRA, C. M. de; PEDROSA, C. E.; DORNAS, M. F. S.; VALADARES, N. R. Atributos genéticos e análise de trilha para o florescimento precoce e características agronômicas da alface. Pesquisa Agropecuária Brasileira, Brasília, v. 49, n. 2, p. 118-124, fev. 2014.

BARBIERI, E.; MELO D. J. F. de; ANDRADE, L. F.; PEREIRA, E. W. L.; COMETTI, N. N. Condutividade elétrica ideal para o cultivo hidropônico de alface em ambiente tropical.

Horticultura Brasileira, v. 28, p.303-308, 2010.

BERBARI, S. A. G.; PASCHOALINO, J. E.; SILVEIRA, N. F. A. Efeito do cloro na água de lavagem para desinfecção de alface minimamente processada. Ciência e Tecnologia de Alimentos, Campinas, v. 21, n. 2, p. 197-201, 2001.

BRASIL. Ministério Da Agricultura, Pecuária e Abastecimento (MAPA). Manual de métodos analíticos oficiais para fertilizantes minerais, orgânicos, organominerais e corretivos. p. 256-289, Brasília: 2007.

CAMBARDELLA, C.A.; ELLIOTT, E. T. Carbon and nitrogen dynamics of soil organic matter fractions from cultivated grassland soils. Soil Science Society American Journal, v. 58,p. 123-130, 1994.

CAO, X,; OLK, D. C.; CHAPPEL, M.; CAMBARDELLA, C. A.; MILLER, L. F.; MAO, J. Solidstate NMR analysis of soil organic matter fractions from integrated physical-chemical extraction. Soil Science Society American Journal, v. 75, p. 1374-1384, 2011.

CASTOLDI, P.; ALBERTI, G.; MERELLA, R.; MELIS, P. Study of the organic matter during municipal solid waste composting aimed at identifying suitable parameters for the evaluation of compost maturity. Waste Management, v. 25, p. 209-213, 2005.

CASTOLDI, Renata. Ocorrência de raças de Bremia lactucae no Estado de São Paulo no triênio 2008 - 2010, e desenvolvimento de linhagens de alface crespa resistentes. 2011. 56f. Tese (Doutorado em agronomia) - Faculdade de Ciências Agrárias e Veterinária, Universidade Estadual Paulista, Jaboticabal, 2011. 
CAVALHEIRO, M. C. H. T. Coletânea de riscos e normas de segurança em laboratório. São Carlos: IQSC, 2010. 140 p.

COMPANHIA AMBIENTAL DO ESTADO DE SÃO PAULO (CETESB). Técnicas de análises bacteriológicas da água: tubos múltiplos. São Paulo, 1998. 95 p.

CORREAA, E. B.; BETTIOL, W.; MORANDI, M. A. B. Controle biológico da podridão de raiz causada por Pythium aphanidermatum e promoção de crescimento de alface hidropônica com Clonostachys rosea. Tropical Plant Pathology, v.35, n.4, p. 1109, 2010.

COSTA, P. C; DIDONE, E. B.; SESSO, T. M.; CAÑIZARES, R. G.; GOTO, R. Condutividade elétrica da solução nutritiva e produção de alface em hidroponia. Scientia Agricola, v. 58, n.3, p. 595-597, Jul.-Set. 2001.

CREAMER, C. A.; FILLEY, T. R.; OLK, D. C.; PLANTE, A.; PELTRE, C.; TOP, S. M.; BOUTTON, T. W. Patterns of soil organic matter loss during long-term laboratory incubation. Organic Geochemistry, v.52, p.23-51, 2012.

CREAMER, C.A., FILLEY, T.R., OLK, D.C., STOTT, D.E., DOOLING, V., BOUTTON, T.W. Changes to soil organic $\mathrm{N}$ dynamics with leguminous woody plant encroachment into grasslands. Biogeochemistry, v.34, p. 1007, 2016.

DAROLT, Moacir Roberto. Biofertilizantes: caracterização química, qualidade sanitária e eficiência em diferentes concentrações na cultura de alface. (Mestrado em Ciência do Solo) - Departamento de Solos e Engenharia Agrícola, Setor de Ciências Agrárias, Universidade Federal do Paraná. Curitiba, 2006.

DELGADO, A., SOLERA DEL RÍO, R., SALES, D., GARCÍA-MORALES J. L. Study of the co-composting process of municipal solid waste and sewage sludge: stability and maturity. Organic Waste Treatments: safety implications. p. 257-260. 2004.

FERNANDES, M.C. Cultivo protegido do tomateiro, sob manejo orgânico, na região metropolitana do estado do Rio de Janeiro. Série Agroecologia, n. 2, p. 1-2, 2000.

FIALHO, L. L.; SILVA, W. T. L.; MILORI, D. M. B. P.; SIMÕES, M. L.; MARTIN-NETO, L. Characterization of organic matter from composting of different residues by physicochemical and spectroscopic methods. Bioresource Technology, v. 101, p. 1927- 1934, 2010.

FIALHO, Lucimar Lopes. Caracterização da matéria orgânica em processo de compostagem por métodos convencionais e espectroscópicos. 2007. 170 f. Tese (Doutorado em Química Analítica) - Instituto de Química de São Carlos, Universidade de São Paulo, São Carlos, 2007.

FRAZÃO, L. A.; SANTANA, I. K. S.; de CAMPOS, D. V. B.; FEIGL, B. J.; CERRI, C. C. Estoques de carbono e nitrogênio e fração leve da matéria orgânica em Neossolo Quartzarênico sob uso agrícola. Pesquisa agropecuária brasileira, Brasília, v.45, n.10, p.1198-1204, out. 2010.

FRITTOLI R. B.; RODRIGUES L. H. Análise de coliformes termotolerantes e salmonela sp. em amostras de hortaliças minimamente processadas. Revista Científica da FHO|UNIARARAS v. 2, n. 2, p. 109-116, 2014.

GALE, W.J., CAMBARDELLA C.A., BAILEY T.B. Surface residue- and root-derived carbon in stable and unstable aggregates. Soil Science Society American Journal, v. 64, p.196-201, 2000.

GALE, W.J.; CAMBARDELLA C.A. Carbon dynamics of surface residue- and root derived organic matter under simulated no-until. Soil Science Society American Journal, v. 64, p. 190-195, 2000. 
GARG. P.; GUPTA, A.; SATY, S. Vermicomposting of different types of waste using Eisenia foetida: A comparative study. Bioresource Technology, v. 97, p. 391-395, 2006.

GONÇALVES, P.A.S.; WERNER, H.; DEBARBA, J.F. Avaliação de biofertilizantes, extratos vegetais e diferentes substâncias alternativas no manejo de tripes em cebola em sistema orgânico. Horticultura Brasileira, Brasília, v. 22, n. 3, p. 659-662, jul-set 2004.

HEDGES, J.I; MANN D.C. The characterization of plant tissues by their lignin oxidation products. Geochimica Cosmochimica Acta, v. 43, p. 1803-1807, 1979.

HELBEL JUNIOR, C., REZENDE, R., DE FREITAS, P. S. L., GONÇALVES, A. C. A., FRIZZONE, J. A. Effect of electric conductivity, ionic concentration and flow of nutrient solutions in the production of hidroponic lettuce. Ciência Agrotecnologia, Lavras, v. 32, n. 4, p. 11421147, jul.-ago. 2008.

JOHNSON, D.C., DOBBERPUHL, D., ROBERTS, R., VANDEBERG, P. Pulsed amperometric detection of carbohydrates, amines and sulfur species in ion chromatography -the current state of research. Journal of Chromatography, v. 640, p. 79-96, 1993.

JOSHI, R.; VIG, A.P. Effect of vermicompost on growth, yield and quality of tomato (Lycopersicum esculentum L). African Journal Basic \& Applied Sciences, v. 2, n. 3-4, p. 117-123, 2010.

LANDGRAF, M. D.; MESSIAS, R. A.; REZENDE, M. O. O. A importância ambiental da vermicompostagem: vantagens e aplicações. São Carlos: Rima, 2005. p. 78-80.

LEE, S. K; CHEONG, S. C. Inducing head formation of iceberg lettuce (Lactuca sativa L.) in the tropics through toot-zone temperature control. Tropical Agriculture, v. 73, p. 345-353, 1996.

LIMA, A. M. N.; da SILVA, I. R.; NEVES, C. L.; NOVAIS, R. F.; BARROS, N. F.; MENDONÇA, E. S.; DEMOLINARI, M. S. M.; LEITE, F. P. Frações da matéria orgânica do solo após três décadas de cultivo de eucalipto no vale do rio doce-MG. Revista Brasileira de Ciência do Solo, v. 32, p. 1053-1063, 2008.

MALAVOLTA, E.; PIMENTEL-GOMES, F.; ALCARDE, J. C. Adubos e adubação. São Paulo: Agronômica Ceres, 2002. p.109-116.

MANGRICH, A. S.; LOBO, M. A.; TANCK, C.B.; WYPYCH, F.; TOLEDO, E. B. S.; GUIMARÃES, E. Criterious preparations and characterization of earthworm composts. Journal of Brazilian Chemical Society, v. 11, n. 2, p. 164-169, 2000.

MAO, J.-D., OLK D.C., FANG X., HE Z., SCHMIDT-ROHR K. Influence of animal manure application on the chemical structures of soil organic matter as investigated by advanced solid-state NMR and FT-IR spectroscopy. Geoderma, v. 146, p. 353-362, 2008.

MARTENS, D., Frankenberger, W. Determination of saccharides by high performance anionexchange chromatography with pulsed amperometric detection. Chromatographia, v. 29, p. 7-12, 1990.

MARTENS, D.A., LOEFFELMANN, K.L. Improved accounting of carbohydrate carbon from plants and soils. Soil Biology and Biochemistry, v. 34, p. 1393-1399, 2002.

MEDEIROS, D. C.; LIMA, B. A. B.; BARBOSA, M. R.; ANJOS, R. S. B.; BORGES, R. D.; CAVALCANTE NETO, J. G.; MARQUES, L. F. Produção de mudas de alface com biofertilizantes e substratos. Horticultura Brasileira, v. 25, p. 433-436, 2007.

MEDEIROS, M. B.; WANDERLEY, P. A.; WANDERLEY, M. J. A. Biofertilizantes líquidos. Revista Biotecnologia Ciência e Desenvolvimento, v. 31, p. 38-44, 2003.

MEDEIROS, M.B. de; LOPES, J. de S. Biofertilizantes líquidos e sustentabilidade agrícola. Bahia Agrícola, v. 7, p. 24-26, 2006. 
NASCIMENTO, Graziela Aparecida Zanardo. Gestão de resíduos em propriedade rural: utilização de resíduos avícolas para a produção de energia e biofertilizante. $113 \mathrm{f}$. (Dissertação de Mestrado) - Escola de Engenharia de Mauá, São Caetano do Sul, p. 23-25, 2011.

NGUYEN, B. V.; OLK, D. C.; CASSMAN, K. G. Nitrogen mineralization from humic acid fractions in rice soils depends and degree of humifcation. Agronomy \& Horticulture: faculty publications, v. 2, p. 108, 2004.

NOGUEIRA, A.R.A.; SOUZA, G.B. Manual de laboratórios: solo, água, nutrição vegetal, nutrição animal e alimentos. São Carlos: Embrapa Pecuária Sudeste, 2005. 334 p.

OLK, D. C.; ANDERS, M. M.; FILLEY, T. R.; ISBELL, C. Crop nitrogen uptake and soil phenols accumulation under continuous rice cropping in Arkansas. Soil Science Society American Journal, v. 73, p. 952-960, 2009.

OLK, D.C., FORTUNA, A., HONEYCUTT, C.W. USING anion chromatography-pulsed amperometry to measure amino compounds in dairy manure-amended soils. Soil Science Society of America Journal, v. 72, p. 1711-1720, 2008.

PAIVA, Jeferson Leandro de. Avaliação microbiológica da alface (Lactuca sativa) em sistema de cultivo hidropônico e no solo, correlacionando os microrganismos isolados com os encontrados em toxinfecções alimentares em municípios da região Noroeste de São Paulo - SP. 115 f. (Dissertação de Mestrado) - Instituto de Biociências, Letras e Ciências Exatas - Universidade Estadual Paulista, 2011.

PEREIRA, M. A. B., SILVA, J. C., MATA, J. F., SILVA, J. C. Uso de biofertilizante foliar em adubação de cobertura da alface cv. Verônica. Pesquisa Aplicada \& Agrotecnologia, v. 3, n. 2, p. 276, 2010.

PINHEIRO, S.; BARRETO, S. B. MB-4 agricultura sustentável, trofobiose e biofertilizantes. Arapiraca: MIBASA, 2000. 273 p.

PINHEIRO, S.; BARRETO, S.B. Agricultura sustentável, trofobiose e biofertilizantes. Florianópolis: Fundação Juquira Candiru, 1996. 273p.

RANGEL, O.J.P.; SILVA, C.A. Estoques de carbono e nitrogênio e frações orgânicas de Latossolo submetido a diferentes sistemas de uso e manejo. Revista Brasileira de Ciência do Solo, v. 31, p. 1609-1623, 2007.

RHODEN, A.C.; SILVA, L.S.; CAMARGO, F.A.O.; BRITZKE, D.; BENEDETTI, E. Mineralização anaeróbica do nitrogênio em solos de várzea do Rio Grande do Sul. Ciência Rural, v. 36, n. 6, p. 1780-1787, 2006.

RIBEIRO, A. C.; GUIMARÃES, P. T. G.; ALVAREZ V. V. H. Recomendações para o uso de corretivos e fertilizantes em Minas Gerais: $5^{\mathrm{a}}$ aproximação. Viçosa, Comissão de Fertilidade do solo do Estado de Minas Gerais, 1999. 180 p.

RIBEIRO, K. S.; FERREIRA, E.; COSTA, M. S. S. M.; GAZOLLA, D.; SZIMANSKI, C. C. Uso de biofertilizante no cultivo de alface hidropônica. Revista Brasileira de Agroecologia, v. 2, n. 2, p. 1600-1603, 2007.

ROS, M., GARCI'A, C. AND T. HERNÁNDEZ. A full-scale study of treatment of pig slurry by composting: Kinetic changes in chemical and microbial properties. Waste Management, v. 26, p. 1108-1118, 2006.

RUIZ, Luis Miguel. Comportamento químico e microbiológico no biofertilizante tipo supermagro. $52 \mathrm{f}$ (Dissertação de Mestrado) - Brasília: Faculdade de Agronomia e Medicina Veterinária, Universidade de Brasília, 2013. 
SANCHES, M.S.; MARTINS, R.; CORDEIRO, P.J.M.; VAZ, L.AA.; VIEIRA, E.M. Validation of the method for determining the 3 - indolacetic acid in water from rivers by high performance liquid chromatography. Revista Ambiente \& Água, Taubaté, v. 4, n. 1, p. 81-92, 2009.

SANTI A.; SCARAMUZZA W. L. M. P.; NEUHAUS A.; DALLACORT R.; KRAUSE W.; TIEPPO R. C. Desempenho agronômico de alface Americana fertilizada com torta de filtro em ambiente protegido. Horticultura Brasileira, v. 31, p. 338-343, 2013.

SANTOS, A. C. V. A ação múltipla do biofertilizante líquido como ferti fitoprotetor em lavouras comerciais. In: ENCONTRO DE PROCESSOS DE PROTEÇÃO DE PLANTAS: CONTROLE ECOLÓGICO DE PRAGAS E DOENÇAS, 1. 2001, Botucatu. Livro de resumos... Botucatu: Agroecológica, 2001. p.91-96.

SANTOS, A. C. V., AKIBA, F. Biofertilizante líquido: uso correto na agricultura alternativa. Rio de Janeiro: Imprensa Universitária, 1996. 35 p.

SILVA, A.F.; PINTO, J.M.; FRANÇA, C.R.R.S.; FERNANDES, S.C.; GOMES, T.C.A; SILVA, M.S.L. da; MATOS, A.N.B. Preparo e uso de biofertilizantes líquidos. Petrolina: Embrapa Semi-Árido, 2007. 130 p.

SILVERSTEIN, R. N.; BASSLER, G. C.; MORRIL, T. C. Identificação espectrométrica de compostos orgânicos. São Paulo: Guanabara, 2010. p. 198.

SKJEMSTAD, J.O., CLARKE P., TAYLOR J.A., OADES J.M., NEWMAN R.H. The removal of magnetic materials from surface soils. A solid state 13C CP/MAS NMR study. Australian Journal Soil Resource, v. 32, p. 1215-1229, 1994.

SOUZA, J. O.; DALPIAN, T.; BRAZ, L. T.; CAMARGO, M. Novas raças de Bremia lactucae, agente causador do míldio da alface, identificadas no estado de São Paulo. Horticultura Brasileira, v. 29, p. 282-286, 2011.

STEVENSON, F. J. Humus chemistry: genesis, composition, reactions. 2. ed. New York: J. Wiley, 1994. 496 p.

SWIFT, R. S. Molecular weight, size, shape, and charge characteristics of humic substances: Some basic considerations. In: HAYES, M. H. B.; MacCARTHY, P.; MALCOLM, R. L.; SWIFT, R. S. (Ed.). Humic substances II: in search of structure. New York: John Wiley, 1989. p. 449-466.

SWIFT, R. S. Organic matter characterization. In: SPARKS, D. L.; PAGE, A. L.; HELMKE, P. A.; LOEPPERT, R. H.; SOLTANPOUR, P. N.; TABATABAI, M. A.; JOHNSTON, C. T.; SUMNER, M. E. (Eds.). Methods of soil analysis: chemical methods. Madison: Soil Science Society of America, 1996. Part 3, p. 1011-1069. (Book Series, 5).

TANAKA, M. T., SENGIK, E., SANTOS, H. S., SCAPIN, C. A. Efeito da aplicação foliar de biofertilizantes, bioestimulantes e micronutrientes na cultura do tomateiro (Lycopersicon esculetum Mill.). Acta Science Agronomy, v. 25, n. 2, p. 315-321, 2003.

TEDESCO, M.J.; SELBACH, P.A.; GIANELLO, C.; CAMARGO, F.A.O. Resíduos orgânicos no solo e impactos no ambiente. In: SANTOS, G.A.; CAMARGO, F.A.O., (Eds).

Fundamentos da matéria orgânica do solo. Porto Alegre: Gêneses, 1999, p. 159-192.

VERONKA, D. A.; FORTUNATO, C. B.; RODRIGUES, A. P. D. A. C.; LAURA, V. A.; PEDRINHO, D. R. Efeito do biofertilizante no crescimento e na produção de alface. Horticultura Brasileira, v. 26, p. 1161-1165, 2008.

VIEIRA, S. Análise de variância: ANOVA. São Paulo: Atlas, 2006. 588 p.

ZOZOLOTTO, T. C.; ZOZOLOTTO, H. C.; SILVA, P. R. D.; LANDGRAF, M. D.; REZENDE, M. O. O. Validação de metodologia para determinação do extrato húmico total em matrizes sólidas. Analytica, v. 61, p. 58-67, 2012. 


\section{APÊNDICE A}

Novos métodos de extração e fracionamento da matéria orgânica

\section{RESUMO DO APÊNDICE}

MENDES, Leandro Antunes. Apêndice A - Novas métodos de extração e fracionamento de matéria orgânica. In: Avaliação das transformações químicas e do potencial agronômico de biofertilizantes líquidos produzidos a partir de resíduos agroindustriais para o manejo sustentável em agricultura orgânica. Tese (Doutorado em Química). Universidade de São Paulo, Instituto de Química de São Carlos, 2017. p. 121-129.

A matéria orgânica do solo (MOS) foi extraída por meio de um procedimento físicoquímico. As amostras de solo foram extraídas em sequência, sendo elas: fração leve (FL), frações de dois tamanhos de matéria orgânica particulada (POM-500um e POM$53 \mu \mathrm{m})$, fração de ácido húmico ligado ao cálcio (CaHA) e frações de ácidos húmicos móveis (MHA). Por definição, a fração leve (FL) da matéria orgânica do solo (MOS) é derivada de resíduos de plantas, raízes e hifas que ainda representam estruturas celulares reconhecíveis. A fração leve possui composição comparável àquela dos materiais vegetais, e seu único mecanismo de proteção atuante é a recalcitrância molecular. A matéria orgânica particulada (POM) é a matéria orgânica associada às frações silte e argila menos alterada em relação à matéria orgânica associada à fração areia e à matéria orgânica leve. O ácido húmico móvel (MHA) é uma fração jovem do ácido húmico relativamente rica em $\mathrm{N}$ e pode ser extraída do solo sem remoção prévia de cátions polivalentes e a fração de ácido húmico ligado ao cálcio ( $\mathrm{CaHA}$ ) é maior que a MHA e é estabilizada por cátions polivalentes. Estas análises trouxeram informações fundamentais e significativas para o conhecimento a respeito da estrutura dos biofertilizantes, o que se traduz em um grande avanço no conhecimento em nível molecular e estrutural destes. Os resultados destas análises, juntamente com os resultados obtidos no Brasil, permitirão propor a relação dessas estruturas com a fertilidade do material. O estágio no exterior também contribuiu para firmar a interação entre os grupos de pesquisa do Laboratório de Química Ambiental com o Laboratório Nacional de Agricultura e Meio Ambiente (USDA/ARS). 


\section{A.1. Materiais e métodos}

\section{A.1.1. Extração da matéria orgânica}

A extração da fração leve (LF) e da fração da matéria orgânica particulada foram extraídas segundo procedimentos de CAMBARDELLA e ELLIOTT (1994) e GALE et al. (2000). As extrações do ácido húmico móvel (MHA) e ácido húmico ligado ao cálcio (CaHA) foram baseadas nos procedimentos de MAO et al. (2008).

Por definição, a fração leve ( $F L)$ da matéria orgânica do solo (MOS) é derivada de resíduos de plantas, raízes e hifas que ainda representam estruturas celulares reconhecíveis. Por ser sensível às práticas de manejo, a determinação da FL é importante na avaliação da qualidade do sistema de manejo em curto prazo (RANGEL \& SILVA, 2007). A fração leve possui composição comparável àquela dos materiais vegetais, e seu único mecanismo de proteção atuante é a recalcitrância molecular (FRAZÃO et al., 2010).

Segundo LIMA et al. (2008), matéria orgânica particulada (POM) é a matéria orgânica associada às frações silte e argila menos alterada em relação à matéria orgânica associada à fração areia e à matéria orgânica leve.

O ácido húmico móvel (MHA) é uma fração jovem do ácido húmico relativamente rica em $\mathrm{N}$ e pode ser extraída do solo sem remoção prévia de cations polivalentes e a fração de ácido húmico ligado ao cálcio (CaHA) é maior que a MHA e é estabilizada por cátions polivalentes (NGUYEN et al., 2004). Segundo RHODEN et al. (2006), os estudos de estrutura química, idade e acumulação de MHA (ácido húmico móvel) e CaHA (cálcio humificado) nos solos de várzea, representaram uma substancial fração do $\mathrm{N}$ orgânico variando de 13 a 23\% do $\mathrm{N}$ total do solo, sugerindo que estas frações são tidas como um amplo impacto nas taxas de mineralização em solos de várzea.

\section{A.1.2. Extração da fração leve}

A fração leve foi extraída por flotação da amostra com solução de politungstato de sódio (PT) com densidade de $1,6 \mathrm{~g} \mathrm{~cm}^{-3}$. Especificamente, foram colocados em frascos de centrífuga $35 \mathrm{~g}$ da amostra e $500 \mathrm{~mL}$ da solução de PT $\left(1,6 \mathrm{~g} \mathrm{~cm}^{-3}\right)$, em triplicata. Os frascos foram centrifugados por 10 minutos a $250 \mathrm{rpm}$. As soluções foram então transferidas para um béquer de $500 \mathrm{~mL}$ e deixadas em repouso durante a noite. Depois disso a fração leve foi removida de cada béquer por sucção a vácuo e 
coletadas em filtro de nylon $20 \mu \mathrm{m}$, em seguida, lavadas com PT em uma béquer de $50 \mathrm{~mL}$. Após a extração LF, o procedimento de GALE e CAMBARDELLA (2000) foi usado para remover a solução de PT a partir da amostra antes da extração das frações de matéria orgânica particulada (POM).

O conteúdo de cada béquer de $500 \mathrm{~mL}$ foi transferido para tubos de centrífuga de $500 \mathrm{~mL}$ e centrifugados a 9800 rpm por 14 minutos. O PT em solução foi decantado para posterior limpeza. Para remover o PT adsorvido no solo, cerca de $250 \mathrm{~mL}$ de água deionizada e $3 \mathrm{~g}$ de $\mathrm{Na}_{2} \mathrm{SO}_{4}$ foram adicionados a cada frasco, seguido de agitação durante 10 minutos em uma mesa agitadora a 250 rpm, centrifugação, e decantação para um recipiente de resíduos. Mais duas lavagens foram realizadas, a única diferença sendo a massa de $\mathrm{Na}_{2} \mathrm{SO}_{4}$ adicionado a cada frasco (1,5 e 1,0 g, respectivamente).

\section{A.1.3. Matéria orgânica particulada - separação por tamanho de classes}

Depois de extrair a LF, cada réplica de amostra foi dispersa com a adição de $120 \mathrm{~mL}$ de metafosfato de sódio $\left(5 \mathrm{~g} \mathrm{~L}^{-1}\right)$, seguido por agitação durante 16 horas num agitador a $250 \mathrm{rpm}$. Em seguida, cada mistura foi eluida por peneiras de 500 e $53 \mu \mathrm{m}$ para que a argila e o silte fossem coletados em um coletor pirex pan (25 por $39 \mathrm{~cm})$. O silte mais a argila de ambas as repetições de laboratório de cada amostras foram reunidos em um recipiente grande. $O$ frasco e as peneiras foram lavados com água deionizada.

Cada fração de POM foi transferida por lavagens com água para um recipiente de secagem previamente pesado e seco durante a noite em uma estufa a $58^{\circ} \mathrm{C}$. $\mathrm{O}$ Pirex contendo o lodo mais a argila também foi seco durante a noite em uma estufa a $58^{\circ} \mathrm{C}$. Posteriormente, o silte mais a argila foram raspados dos pratos pirex e finalmente macerados com um almofariz e pilão. As massas foram registradas para todas as frações.

As amostras foram preparadas para posterior análise em RMN. As amostras foram agitadas com repetidas lavagens de $2 \%$ de HF $(6 \mathrm{~g} / 100 \mathrm{~mL})$ em um agitador a 120 rpm para dissolver os componentes inorgânicos, seguido por centrifugação e decantação para um recipiente de resíduos. Com uma ligeira modificação da sequência de SKJEMSTAD et al. (1994), os produtos foram lavados por 1 hora (cinco vezes), 64 h (uma vez) e 16 horas (três vezes). Finalmente, os compostos foram 
lavadas duas vezes com $\mathrm{CaCl}_{2} 0,5 \mathrm{mmol} \mathrm{L}^{-1}$ para remover $\mathrm{HF}$ e secos em uma estufa a $58^{\circ} \mathrm{C}$ (SKJEMSTAD et al., 1994).

\section{A.1.4. Extração de ácidos húmicos móveis ligados a cálcio}

Após a extração de POM, as duas frações húmicas foram extraídas seguindo o procedimento de MAO et al. (2008). O lodo seco, mais o material de argila de cada amostra foram igualmente divididos em dois frascos de centrífuga de $500 \mathrm{ml}$.

O conteúdo de cada frasco foi extraído em $350 \mathrm{~mL}$ de $\mathrm{NaOH} 0,25 \mathrm{~mol} \mathrm{~L}^{-1}$ durante uma extração de 20 horas sob uma atmosfera de $\mathrm{N}_{2}$. Os frascos foram, em seguida, centrifugados e o sobrenadante decantado e acidificado até $\mathrm{pH} 2 \mathrm{com} \mathrm{HCl} 2$ mol L-1 para precipitar o ácido húmico móvel (MHA). A amostra foi agitada durante a noite com $\mathrm{NaOH}$ 0,25 mol L-1 mais duas vezes, e o MHA resultante das três lavagens foram coletados em um mesmo frasco.

O lodo mais a argila foram descalcificados com lavagens com $\mathrm{HCl} \mathrm{0,2} \mathrm{mol} \mathrm{L}^{-1}$ e centrifugação até que o $\mathrm{pH}$ do sobrenadante diminuísse para menor que $1,0 . \mathrm{O} \mathrm{HCl}$ em excesso foi então removido com lavagens de água deionizada até que o $\mathrm{pH}$ do sobrenadante ficasse acima de 2,0, de preferência entre 2,5 a 3,0. Finalmente, o sedimento mais a argila foi novamente extraído durante $20 \mathrm{~h}$ com NaOH 0,25 mol L-1 sob uma atmosfera de $\mathrm{N}_{2}$, para extrair a fração húmica ligada ao cálcio (CaHA). Essa extração foi repetida duas vezes e os três precipitados de CaHA foram também coletados. Ambas as frações de MHA e CaHA foram então purificados de contaminantes com ressolubilização em uma solução de $\mathrm{KOH}-\mathrm{KCl}$ e reprecipitação com HCl (SWIFT, 1996).

As amostras foram submetidas a uma extração de 24 horas com $\mathrm{HCl} 0,2 \%$ e HF 0,2\%, e seguidas por 3 dias de diálise em soluções sucessivamente mais fracas de $\mathrm{HCl}\left(0,1 \mathrm{~mol} \mathrm{~L}^{-1}, 0,05 \mathrm{~mol} \mathrm{~L}^{-1}\right.$ e $\left.0,01 \mathrm{~mol} \mathrm{~L}^{-1}\right)$ e no final somente água deionizada. Finalmente, as frações foram congeladas e liofilizadas para posteriores análises.

\section{A.1.5. Extração da matéria orgânica total}

A matéria orgânica total foi extraída por lavagem da amostra com HF 2\%, seguindo o procedimento descrito acima para as frações de POM (SKJEMSTAD et al., 1994). 


\section{A.2. Resultados e discussão}

\section{A.2.1. Extrações de matéria orgânica}

Em paralelo com as análises dos biofertilizantes, foi feito na USDA/ARS nos EUA um experimento de novas extrações de matéria orgânica do solo. Para isso, coletaram-se 20 amostras de solos em um campo (Joel Engle Field) de rotação de milho e soja, onde o laboratório em questão acompanha um estudo há vários anos consecutivos a respeito da aplicação de produto húmico no solo e sua resposta na fertilidade das culturas. As amostras foram coletadas em $15 \mathrm{~cm}$ de profundidade, sempre preocupando em coletar amostras lado a lado, sendo uma o controle (amostras 1, 3, 5, 7, 8, 11, 12, 15, 17 e 19) e a outra a amostra com tratamento húmico (amostras 2, 4, 6, 9, 10, 13, 14, 16, 18 e 20) amostrados conforme a Figura A.1.

Figura A.1 - Esquema do campo onde foram coletadas as amostras de solos, com os respectivos nomes das áreas e dos números das amostras, sendo: amostras controle $(1,3$, $5,7,8,11,12,15,17$ e 19) e amostras com tratamento húmico (amostras 2, 4, 6, 9, 10, 13, $14,16,18$ e 20$)$.

Transecto 1

Transecto 2

\begin{tabular}{|c|c|c|c|c|c|}
\hline \multicolumn{6}{|c|}{ Ridgetop soil } \\
\hline 10 & 8 & & & 20 & 19 \\
\hline 9 & 7 & & & & \\
\hline \multicolumn{6}{|c|}{ Shoulder soil } \\
\hline \multicolumn{6}{|c|}{ Sideslope soil } \\
\hline 6 & 5 & & & 18 & 17 \\
\hline \multicolumn{6}{|c|}{ Toeslope soil } \\
\hline 4 & 3 & & & & \\
\hline \multicolumn{6}{|c|}{ Lowland soil } \\
\hline & & 14 & 13 & & \\
\hline 2 & 1 & 11 & 12 & 16 & 15 \\
\hline
\end{tabular}


Segundo informações do local, o solo mais próximo do lowland soil, ou seja, na parte inferior do esquema, apresenta maior quantidade de carbono em sua composição quando comparado com os solos no topo do esquema (ridgetop soil), logo, os solos mais ricos em carbono, espera-se uma maior dificuldade em ver a influência do produto húmico em relação aos solos mais arenosos, pois o próprio carbono já presente nos solos acaba por interferir no acumulo das substâncias húmicas.

O grupo de pesquisa visitado tem utilizado um procedimento de fracionamento complexo para extração de frações jovens de matéria orgânica do solo. Essas frações nos permitem avaliar os efeitos das práticas de gestão do solo sobre o sequestro de carbono no solo e também a ciclagem de nutrientes. O mesmo grupo também tem documentado um reforço do crescimento radicular das culturas quando aplicado esses produtos húmicos, a hipótese é de que isso resultaria em sequestro de carbono no solo.

A Tabela A.1 a seguir apresenta os resultados em miligramas (mg) das frações extraídas dos 20 solos.

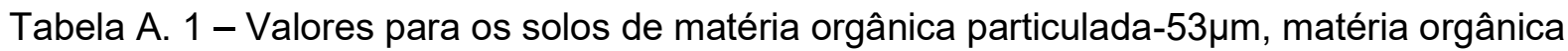

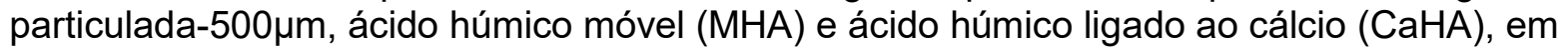
miligramas (mg).

\begin{tabular}{ccccc}
\hline Amostra & POM-53 $\boldsymbol{\mu m}$ & POM-500 $\boldsymbol{\mu m}$ & MHA & CaHA \\
\hline $\mathbf{1}$ & $1.559,80$ & 370,9 & 335,5 & 229,8 \\
$\mathbf{2}$ & $1.483,20$ & 310,6 & 341,4 & 192,5 \\
$\mathbf{3}$ & $1.782,20$ & 331 & 605,2 & 222,3 \\
$\mathbf{4}$ & $1.480,40$ & 223 & 433,5 & 198,4 \\
$\mathbf{5}$ & $1.578,30$ & 177,3 & 235,5 & 134,4 \\
$\mathbf{6}$ & $1.736,40$ & 161,1 & 236,3 & 134,8 \\
$\mathbf{7}$ & $1.960,30$ & 167 & 257,8 & 191,7 \\
$\mathbf{9}$ & $1.658,40$ & 159,4 & 279,6 & 204,5 \\
$\mathbf{8}$ & $2.186,30$ & 399,2 & 368,7 & 242,6 \\
$\mathbf{1 0}$ & $2.109,30$ & 394 & 384,7 & 202,1 \\
$\mathbf{1 1}$ & $1.787,50$ & 490 & 552,6 & 280,9 \\
\hline
\end{tabular}




\begin{tabular}{rrrrr}
\hline 14 & $1.797,90$ & 550 & 510 & 282,4 \\
12 & $1.586,60$ & 652,1 & 433,1 & 337,7 \\
13 & $1.762,10$ & 607,5 & 462,3 & 322,2 \\
15 & $2.247,70$ & 289,4 & 917,9 & 422,8 \\
\hline 16 & $1.725,30$ & 272,6 & 878,9 & 397,8 \\
17 & $3.405,80$ & 338,2 & 411,7 & 269,1 \\
18 & $1.721,50$ & 259,7 & 452,3 & 246,5 \\
19 & $1.982,90$ & 572,4 & 509,1 & 287,8 \\
\hline $\mathbf{2 0}$ & $2.056,70$ & 467,8 & 491,8 & 315,1 \\
\hline
\end{tabular}

Como pode-se observar na Figura A.1, o campo de coleta é dividido em 2 transectos, que vão de solos de textura fina com alto teor de carbono (sul/parte inferior da Figura) até solos erodidos com baixo teor de carbono (norte/parte superior da Figura).

Em geral, os resultados mostram que a fração mais jovem dos ácidos húmicos (MHA) aumentou nos solos onde foi aplicado o produto húmico quando comparado com a amostra controle para a maioria dos pares de amostras. Esse resultado não foi obtido para a fração CaHA, como pode-se observar, os resultados em alguns casos apresentam maior fração na amostra controle do que na com aplicação do produto. Uma hipótese para isso é que a fração mais velha (CaHA) demora a ser formada, ou seja, esse resultado de aumento da fração húmica ligada ao cálcio só poderá ser observado em longo prazo.

O próximo passo para o estudo em questão será a caracterização bioquímica das frações extraídas, as mesmas feitas nos biofertilizantes (carboidratos, fenóis, aminoácidos), e amostras dos solos in natura. Além disso, será feito estudos das propriedades físicas desses locais para determinar se os reservatórios de carbono melhoram com a aplicação do produto húmico. Com o mesmo estudo o grupo esperase fazer em outro campo onde o produto húmico já está sendo aplicado há mais tempo e assim ver se o produto influencia em todas as frações dos solos. 


\section{A.3. Conclusões}

Essas análises trouxeram informações fundamentais e significativas para o conhecimento a respeito da estrutura dos biofertilizantes, o que se traduz em um grande avanço no conhecimento em nível molecular e estrutural destes. Os resultados destas análises, juntamente com os resultados obtidos no Brasil, permitirão propor a relação dessas estruturas com a fertilidade do material.

O estágio no exterior também contribuiu para firmar a interação entre os grupos de pesquisa do Laboratório de Química Ambiental com o Laboratório Nacional de Agricultura e Meio Ambiente (USDA/ARS). 


\section{ANEXO I}

Laudo das análises microbiológicas feitas nas alfaces e biofertilizantes.

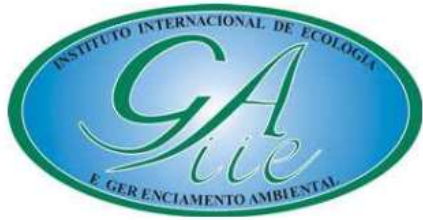

\section{Associação Instituto Internacional de Ecologia e Gerenciamento Ambiental}

Cliente: Sr. Leandro Antunes Mendes (Doutorando em Química Ambiental)

Empresa: Laboratório de Química Ambiental (IQSC/USP)

Cidade: São Carlos (SP)

Contato: Imendes7.lam@gmail.com

Especificação do serviço: execução de análises microbiológicas - Coliformes Totais e Fecais (Escherichia coli) - em 03 amostras de folhas de alface.

\section{DADOS SOBRE AS AMOSTRAS COLETADAS:}

Tipo de amostra coletada: folhas de alface (03 amostras).

Data da coleta: 10/11/2016. Horário: desconhecido.

Entrada no Laboratório: 10/11/2016 (período da tarde).

Condições meteorológicas: desconhecidas.

Número de pontos de coleta: 03 . Responsável pela coleta: próprio cliente.

Análise $n^{\circ}$ 0048-F/2016

\section{RESULTADOS LABORATORIAIS OBTIDOS:}

1) Parâmetros Microbiológicos (amostras de folhas de alface):

\begin{tabular}{|c|c|}
\hline Amostra: Alface 01 & Resultados Obtidos \\
\hline Coliformes Totais & $>2419,6 \mathrm{NMP} / 100 \mathrm{~mL}$ \\
\hline Coliformes Fecais (Escherichia coli) & Ausência \\
\hline
\end{tabular}

\begin{tabular}{|c|c|}
\hline Amostra: Alface 02 & Resultados Obtidos \\
\hline Coliformes Totais & $>2419,6 \mathrm{NMP} / 100 \mathrm{~mL}$ \\
\hline Coliformes Fecais (Escherichia coli) & Ausência \\
\hline
\end{tabular}

\begin{tabular}{|c|c|}
\hline Amostra: Alface $\mathbf{0 3}$ & Resultados Obtidos \\
\hline Coliformes Totais & $>2419,6 \mathrm{NMP} / 100 \mathrm{~mL}$ \\
\hline Coliformes Fecais (Escherichia coli) & Ausência \\
\hline
\end{tabular}

\section{OBSERVACÕES:}

Os procedimentos das análises executadas estão de acordo com os padrões exigidos e estabelecidos pelo Standard Methods for the Examination of Water and Wastewater, $21^{\mathrm{a}}$ edição, 2005.

Exames microbiológicos de Coliformes Totais e Fecais (Escherichia coli) determinados através do método de substrato definido COLILERT ${ }^{\circledR}$.

São Carlos, 11 de novembro de 2016.

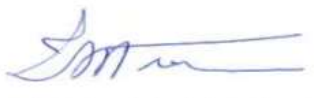

Profa. Dra. Takako Matsumura Tundisi

Responsável Técnica CRBio n ${ }^{\circ}$ 033694/01-D 


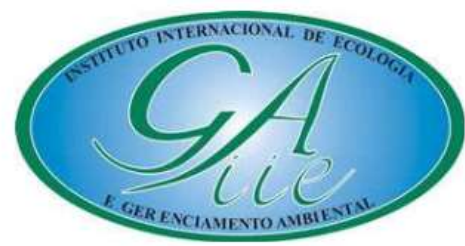

\section{Associação Instituto Internacional de Ecologia e Gerenciamento Ambiental}

Cliente: Sr. Leandro Antunes Mendes (Doutorando em Química Ambiental)

Empresa: Laboratório de Química Ambiental (IQSC/USP)

Cidade: São Carlos (SP)

Contato: Imendes7.lam@gmail.com

Especificação do serviço: execução de análises microbiológicas - Coliformes

Totais e Fecais (Escherichia coli) - em 02 amostras de folhas de alface.

\section{DADOS SOBRE AS AMOSTRAS COLETADAS:}

Tipo de amostra coletada: folhas de alface (02 amostras).

Data da coleta: 15/02/2017. Horário: $15 \mathrm{~h} 00 \mathrm{~min}$.

Entrada no Laboratório: 16/02/2017 (período da manhã).

Condições meteorológicas: desconhecidas.

Número de pontos de coleta: 02 . Responsável pela coleta: próprio cliente.

Análise $n^{\circ}$ 0007-F/2017

\section{RESULTADOS LABORATORIAIS OBTIDOS:}

1) Parâmetros Microbiológicos (amostras de folhas de alface):

\begin{tabular}{|c|c|}
\hline Amostra: Alface M1 & Resultados Obtidos \\
\hline Coliformes Totais & $>2419,6$ NMP/100mL \\
\hline Coliformes Fecais (Escherichia coli) & Ausência \\
\hline
\end{tabular}

\begin{tabular}{|c|c|}
\hline Amostra: Alface M2 & Resultados Obtidos \\
\hline Coliformes Totais & $>2419,6 \mathrm{NMP} / 100 \mathrm{~mL}$ \\
\hline Coliformes Fecais (Escherichia coli) & $488,4 \mathrm{NMP} / 100 \mathrm{~mL}$ \\
\hline
\end{tabular}

\section{OBSERVACÕES:}

Os procedimentos das análises executadas estão de acordo com os padrões exigidos e estabelecidos pelo Standard Methods for the Examination of Water and Wastewater, 21 ${ }^{\mathrm{a}}$ edição, 2005.

Exames microbiológicos de Coliformes Totais e Fecais (Escherichia coli) determinados através do método de substrato definido COLILERT ${ }^{8}$.

São Carlos, 20 de fevereiro de 2017.

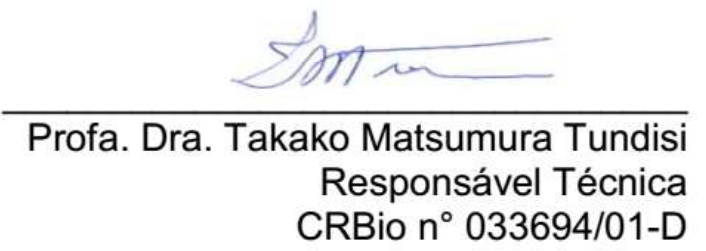




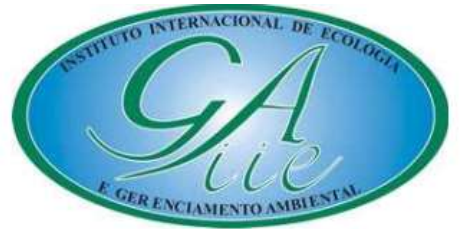

\section{Associação Instituto Internacional de Ecologia e Gerenciamento Ambiental}

Cliente: Sr. Leandro Antunes Mendes (Doutorando em Química Ambiental)

Empresa: Laboratório de Química Ambiental (IQSC/USP)

Cidade: São Carlos (SP)

Contato: Imendes7.lam@gmail.com

Especificação do serviço: execução de análises microbiológicas - Coliformes Totais e Fecais (Escherichia coli) - em 04 amostras de biofertilizantes líquidos e 04 amostras de biossólido (resíduo orgânico).

\section{DADOS SOBRE AS AMOSTRAS COLETADAS:}

Tipos de amostras coletadas: biofertilizantes líquidos (04 amostras) e biossólido (resíduo orgânico) (04 amostras).

Data da coleta: 18/01/2017. Horário: desconhecido.

Entrada no Laboratório: 18/01/2017 (período da manhã).

Condições meteorológicas: desconhecidas.

Número de pontos de coleta: 08 . Responsável pela coleta: próprio cliente.

Análise $n^{\circ}$ 0001-F/2017

\section{RESULTADOS LABORATORIAIS OBTIDOS:}

1) Parâmetros Microbiológicos (Amostras de Biofertilizantes):

\begin{tabular}{|c|c|}
\hline Amostra: Biofertilizante M1 & Resultados Obtidos \\
\hline Coliformes Totais & $>2419,6 \mathrm{NMP} / 100 \mathrm{~mL}$ \\
\hline Coliformes Fecais (Escherichia coli) & Ausência \\
\hline
\end{tabular}

\begin{tabular}{|c|c|}
\hline Amostra: Biofertilizante M2 & Resultados Obtidos \\
\hline Coliformes Totais & $>2419,6 \mathrm{NMP} / 100 \mathrm{~mL}$ \\
\hline Coliformes Fecais (Escherichia coli) & $46110 \mathrm{NMP} / 100 \mathrm{~mL}$ \\
\hline
\end{tabular}

\begin{tabular}{|c|c|}
\hline Amostra: Biofertilizante M3 & Resultados Obtidos \\
\hline Coliformes Totais & $>2419,6 \mathrm{NMP} / 100 \mathrm{~mL}$ \\
\hline Coliformes Fecais (Escherichia coli) & Ausência \\
\hline
\end{tabular}

\begin{tabular}{|c|c|}
\hline Amostra: Biofertilizante M4 & Resultados Obtidos \\
\hline Coliformes Totais & $>2419,6 \mathrm{NMP} / 100 \mathrm{~mL}$ \\
\hline Coliformes Fecais (Escherichia coli) & $>2419,6 \mathrm{NMP} / 100 \mathrm{~mL}$ \\
\hline
\end{tabular}




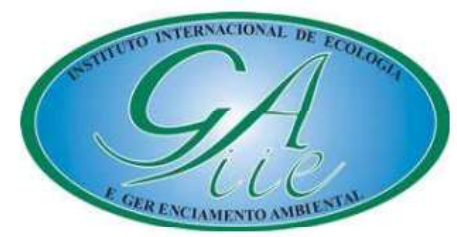

\section{Associação Instituto Internacional de Ecologia e Gerenciamento Ambiental}

2) Parâmetros Microbiológicos (Amostras de Biossólido):

\begin{tabular}{|c|c|}
\hline Amostra: Biossólido M1 & Resultados Obtidos \\
\hline Coliformes Totais & $\begin{array}{c}8110081 \mathrm{NMP} / \mathrm{g} \text { de resíduo } \\
\text { orgânico }\end{array}$ \\
\hline Coliformes Fecais (Escherichia coli) & $9361 \mathrm{NMP} / \mathrm{g}$ de resíduo orgânico \\
\hline
\end{tabular}

\begin{tabular}{|c|c|}
\hline Amostra: Biossólido M2 & Resultados Obtidos \\
\hline Coliformes Totais & $\begin{array}{c}\text { 9089561 NMP/g de resíduo } \\
\text { orgânico }\end{array}$ \\
\hline Coliformes Fecais (Escherichia coli) & $\begin{array}{c}742629 \mathrm{NMP} / \mathrm{g} \text { de resíduo } \\
\text { orgânico }\end{array}$ \\
\hline
\end{tabular}

\begin{tabular}{|c|c|}
\hline Amostra: Biossólido M3 & Resultados Obtidos \\
\hline Coliformes Totais & $\begin{array}{c}>23398123 \mathrm{NMP} / \mathrm{g} \text { de resíduo } \\
\text { orgânico }\end{array}$ \\
\hline Coliformes Fecais (Escherichia coli) & Ausência \\
\hline
\end{tabular}

\begin{tabular}{|c|c|}
\hline Amostra: Biossólido M4 & Resultados Obtidos \\
\hline Coliformes Totais & $\begin{array}{c}>23105423 \mathrm{NMP} / \mathrm{g} \text { de resíduo } \\
\text { orgânico }\end{array}$ \\
\hline Coliformes Fecais (Escherichia coli) & Ausência \\
\hline
\end{tabular}

\section{OBSERVACÕES:}

Os procedimentos das análises executadas estão de acordo com os padrões exigidos e estabelecidos pelo Standard Methods for the Examination of Water and Wastewater, $21^{a}$ edição, 2005.

Exames microbiológicos de Coliformes Totais e Fecais (Escherichia coli) determinados através do método de substrato definido COLILERT ${ }^{\circledR}$.

São Carlos, 20 de janeiro de 2017.

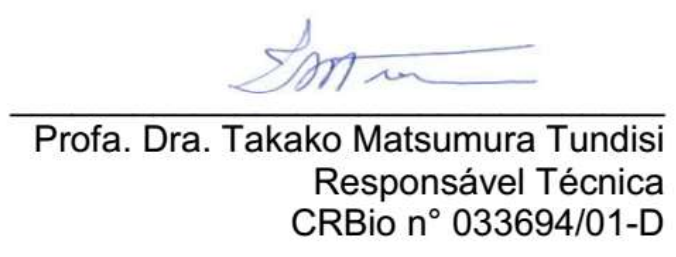




\section{ANEXO II}

Cartas controle da análise biométrica dividida por misturas e por atributos:

\section{Circunferência da cabeça}

- M1

\section{Gráfico de Valores Individuais}

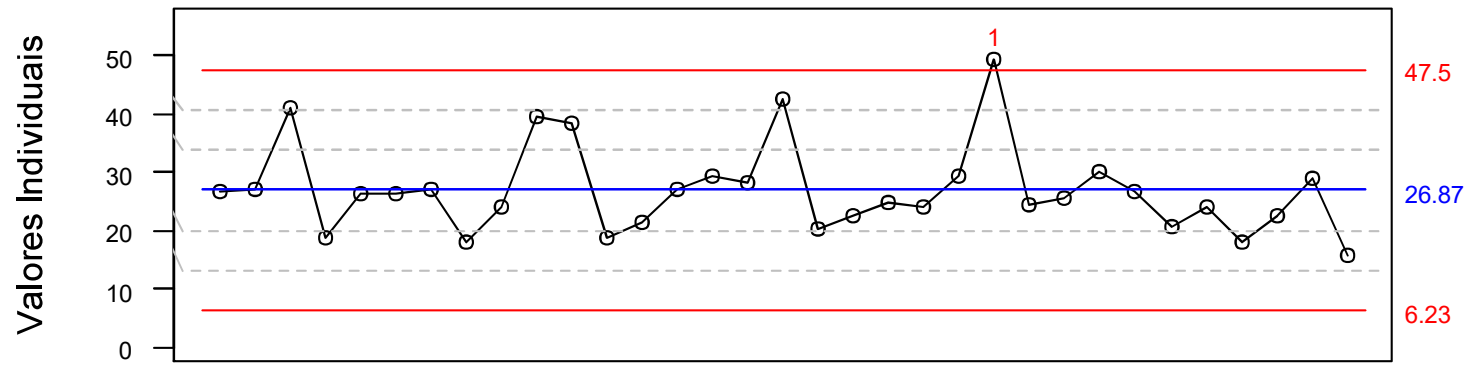

- $\mathrm{M} 2$

Gráfico de Valores Individuais

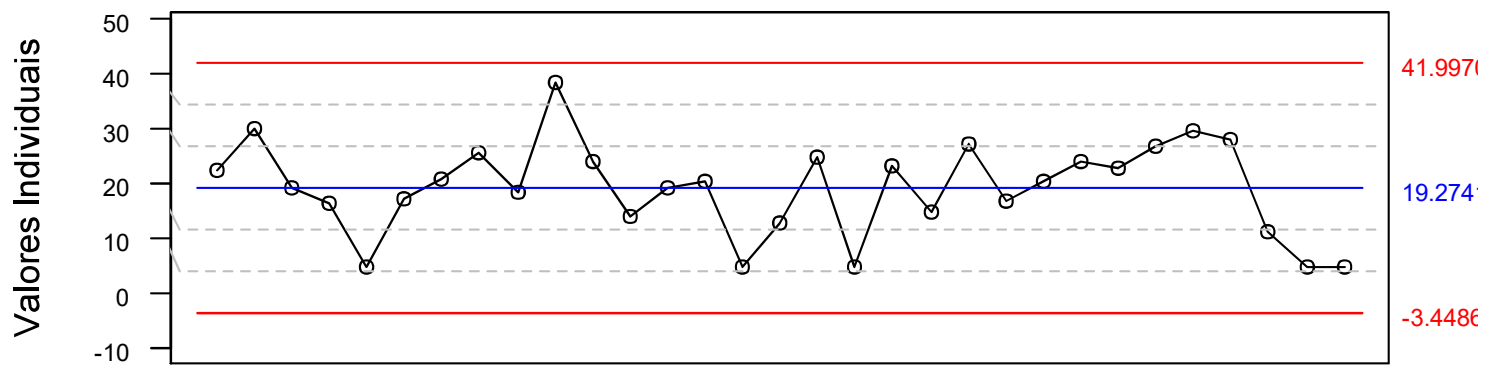

- $\mathrm{M} 3$

Gráfico de Valores Individuais

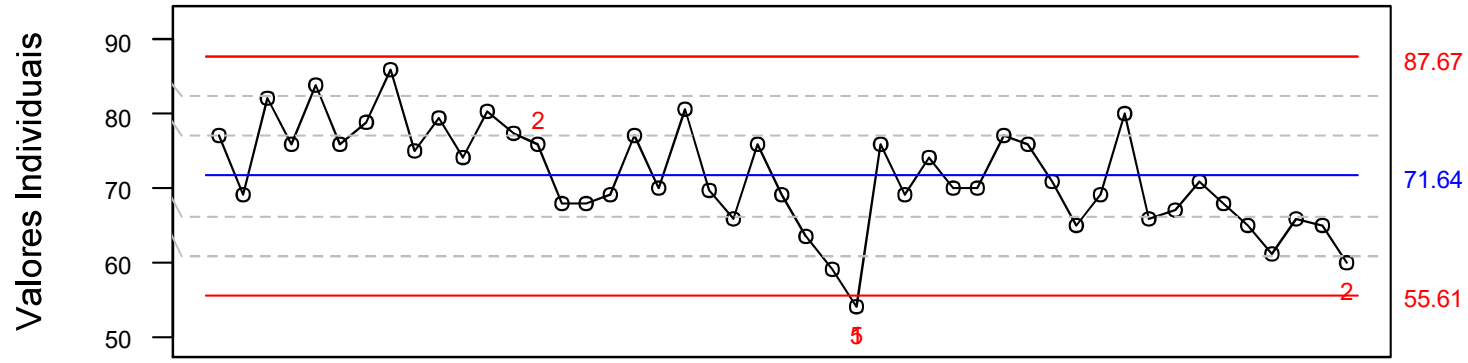


- M4

\section{Gráfico de Valores Individuais}

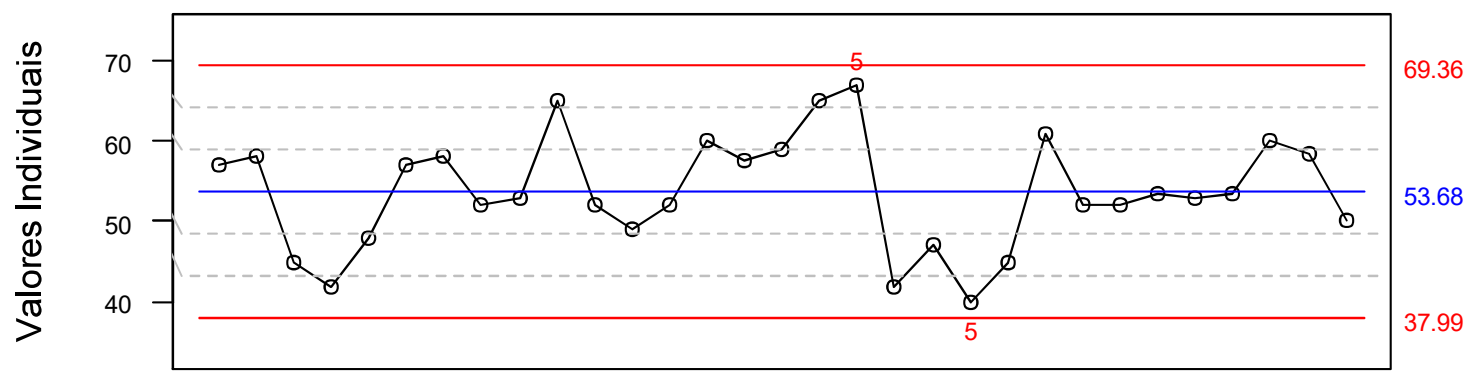

2. Massa fresca parte aérea

- $\mathrm{M} 1$

\section{Gráfico de Valores Individuais}

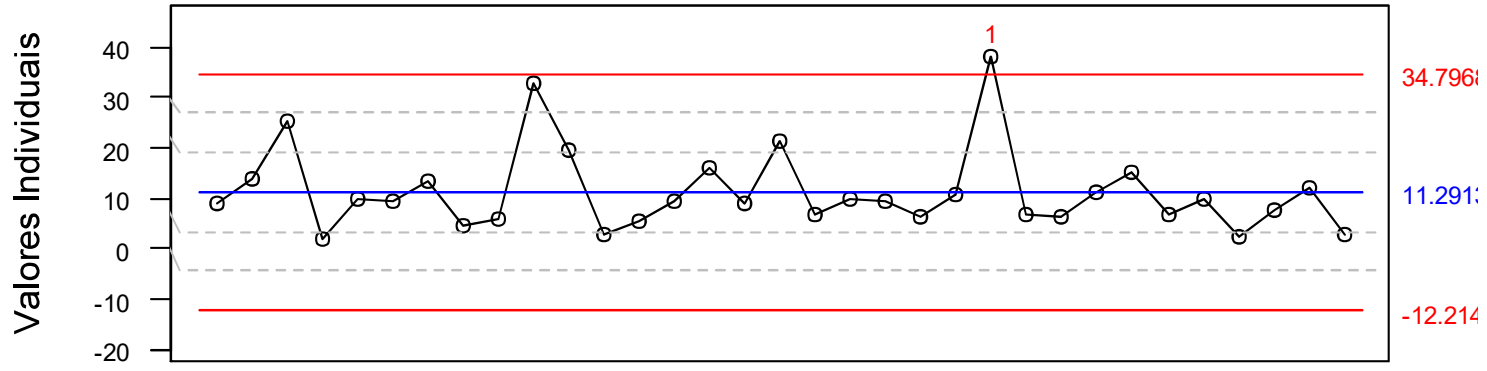

- $\mathrm{M} 2$

\section{Gráfico de Valores Individuais}

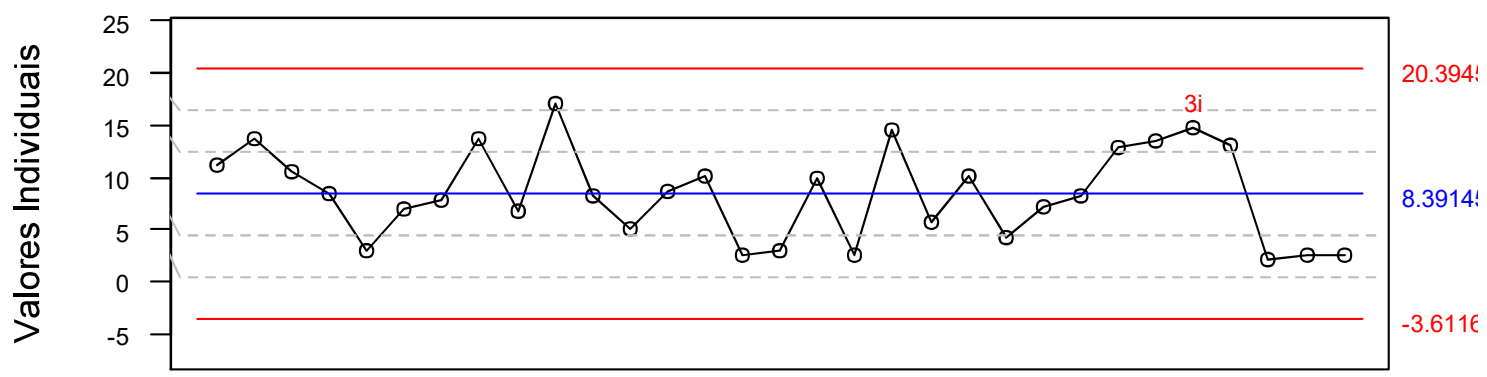


- $\mathrm{M} 3$

Gráfico de Valores Individuais

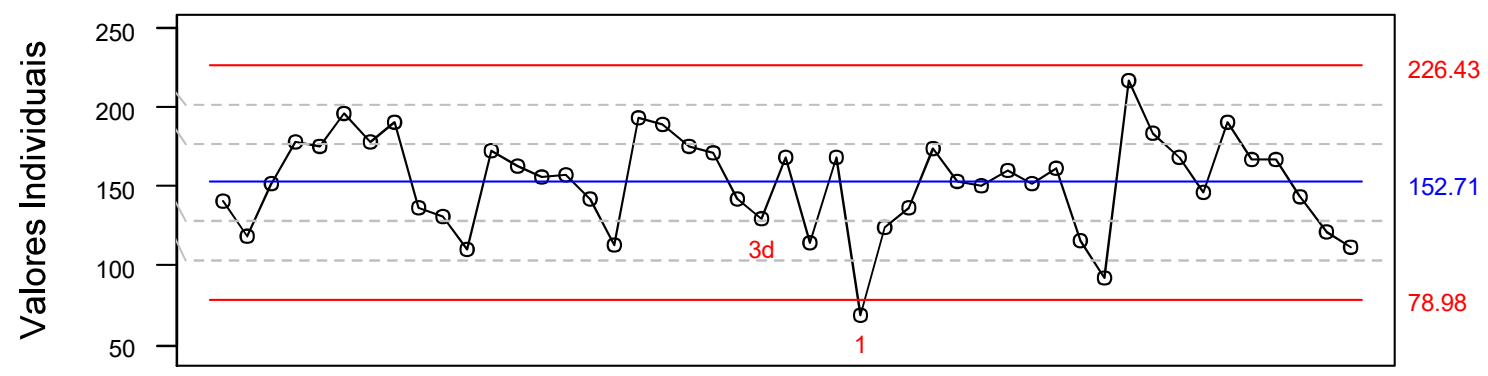

- M4

\section{Gráfico de Valores Individuais}

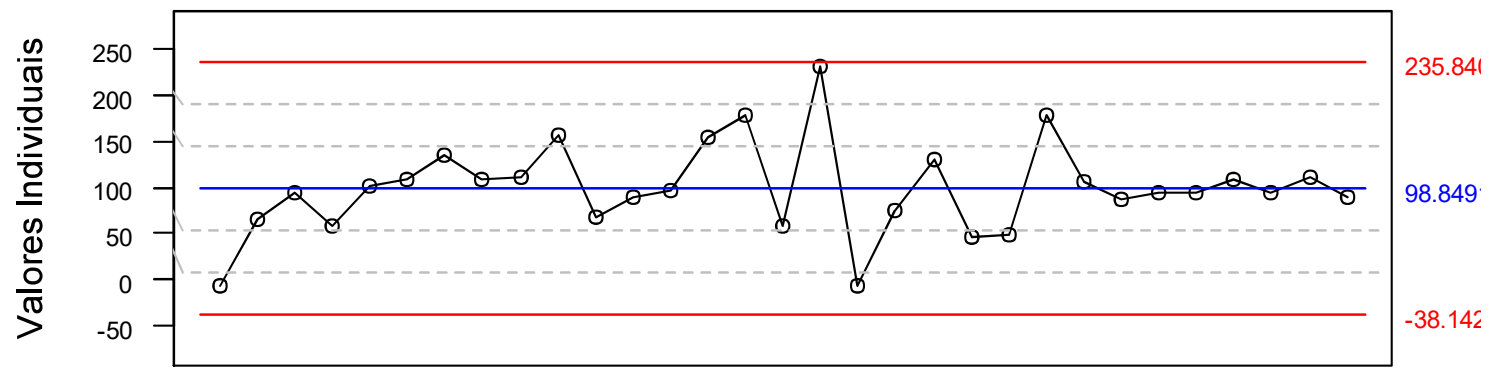

3. Número de folhas

- M1

Gráfico de Valores Individuais

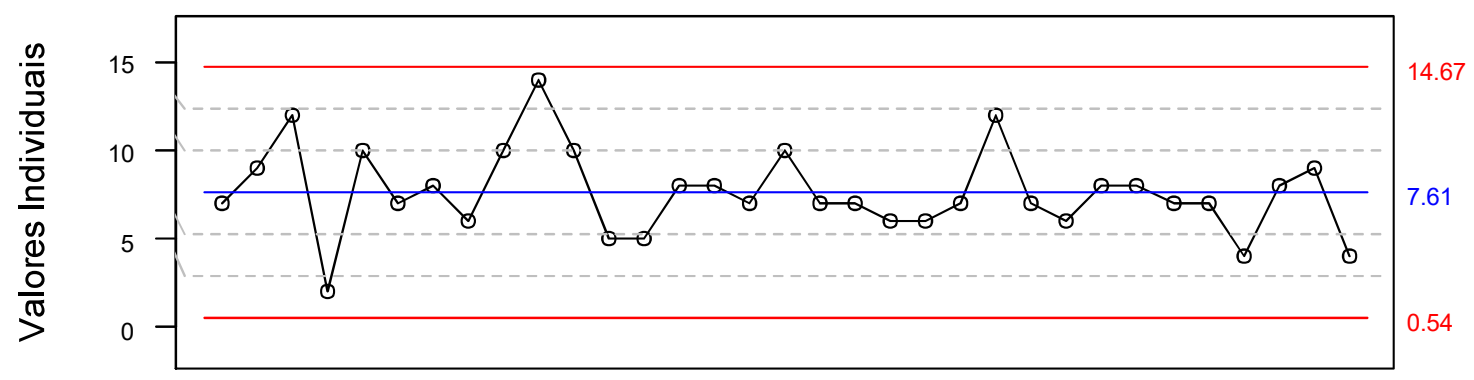


- $\mathrm{M} 2$

\section{Gráfico de Valores Individuais}

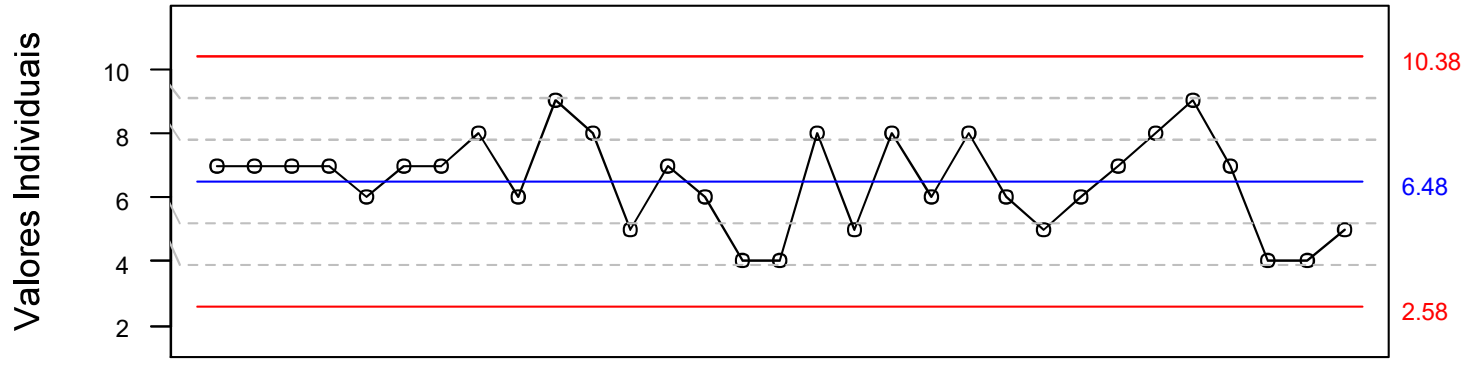

- M3

\section{Gráfico de Valores Individuais}

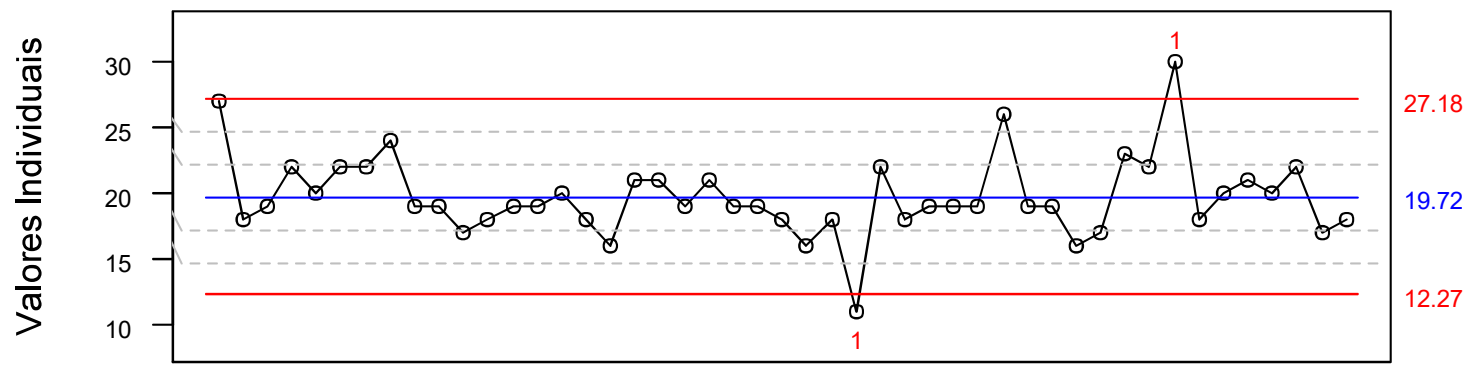

- M4

Gráfico de Valores Individuais

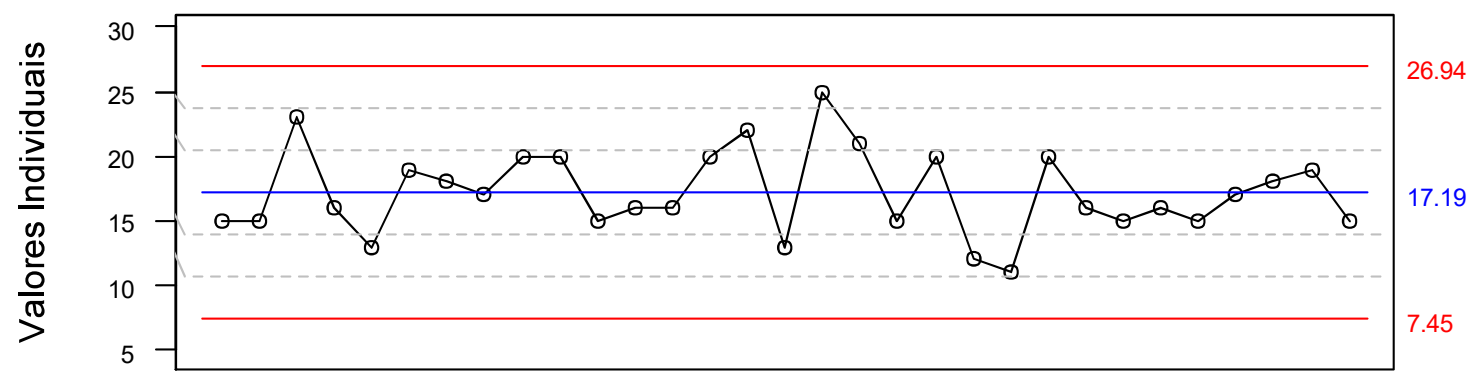




\section{Comprimento da folha}

- M1

\section{Gráfico de Valores Individuais}

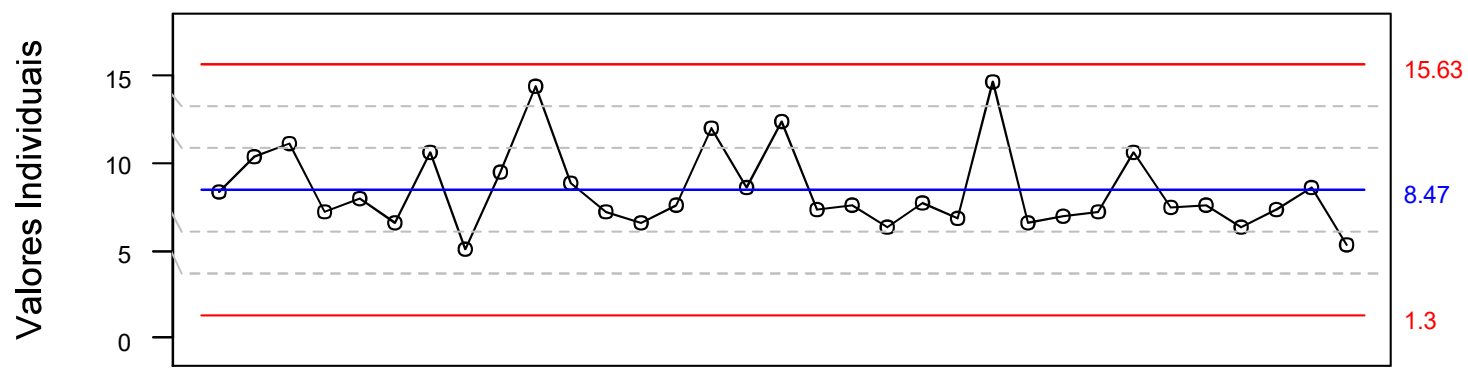

- $\mathrm{M} 2$

\section{Gráfico de Valores Individuais}

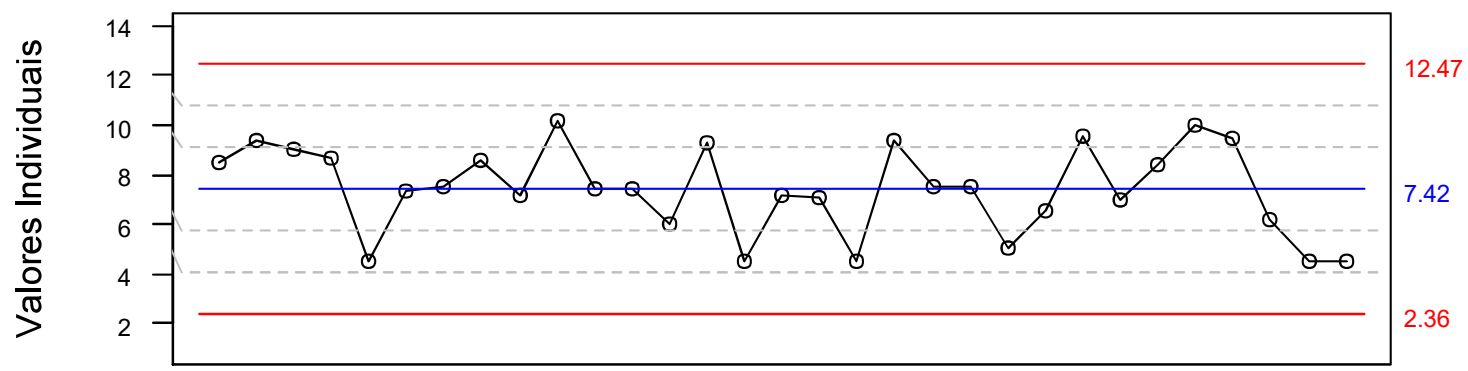

- M3

\section{Gráfico de Valores Individuais}

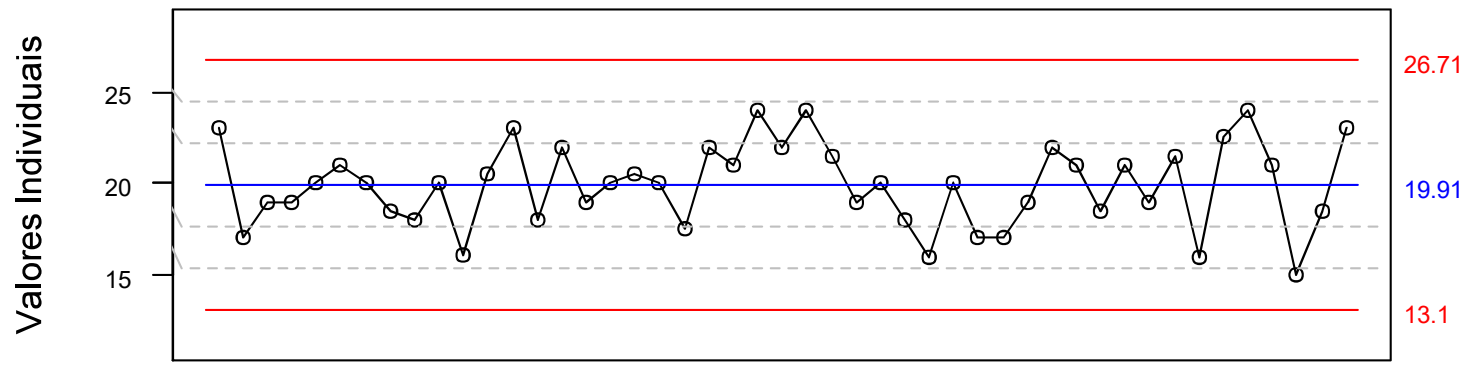


Gráfico de Valores Individuais

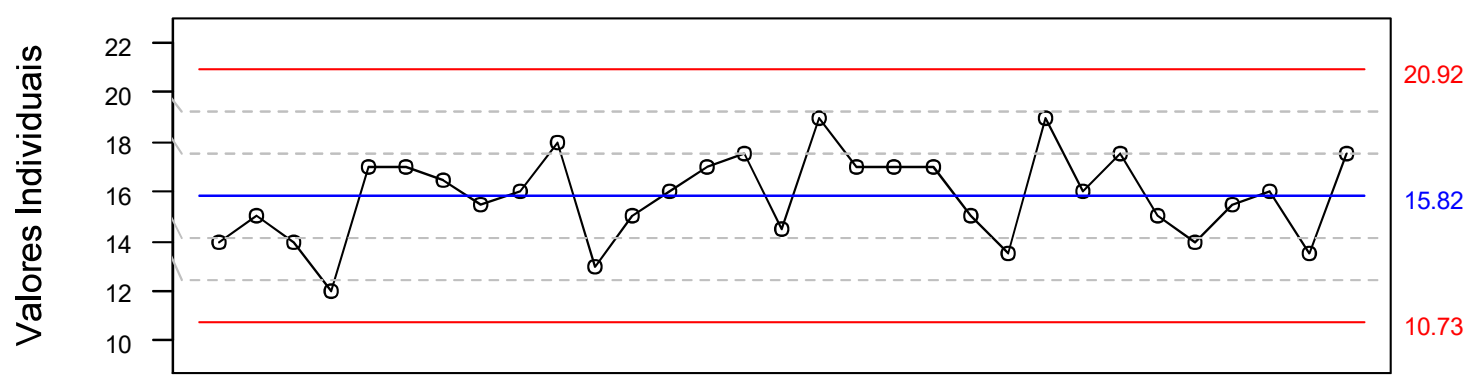

5. Altura do pé

- M1

Gráfico de Valores Individuais

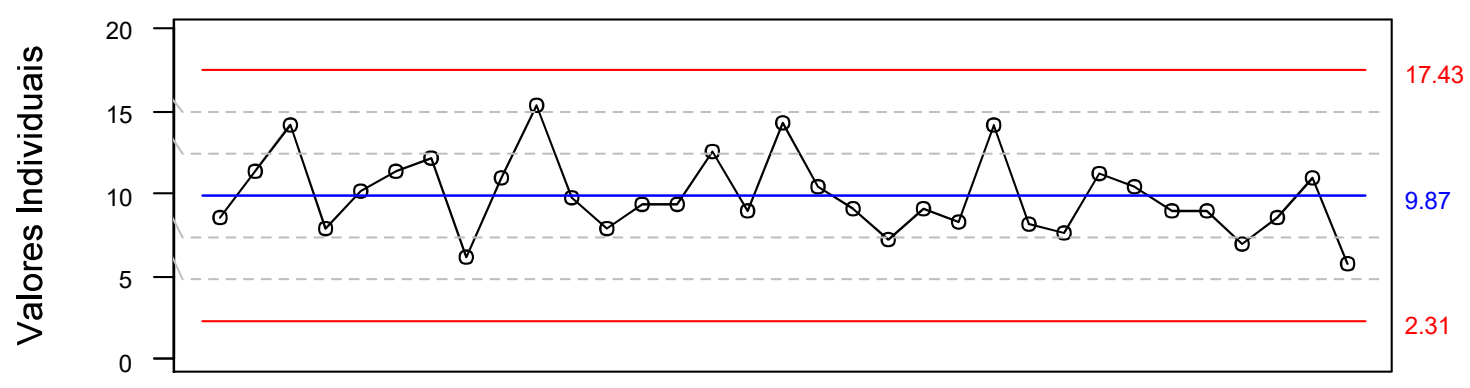

- $\mathrm{M} 2$

\section{Gráfico de Valores Individuais}

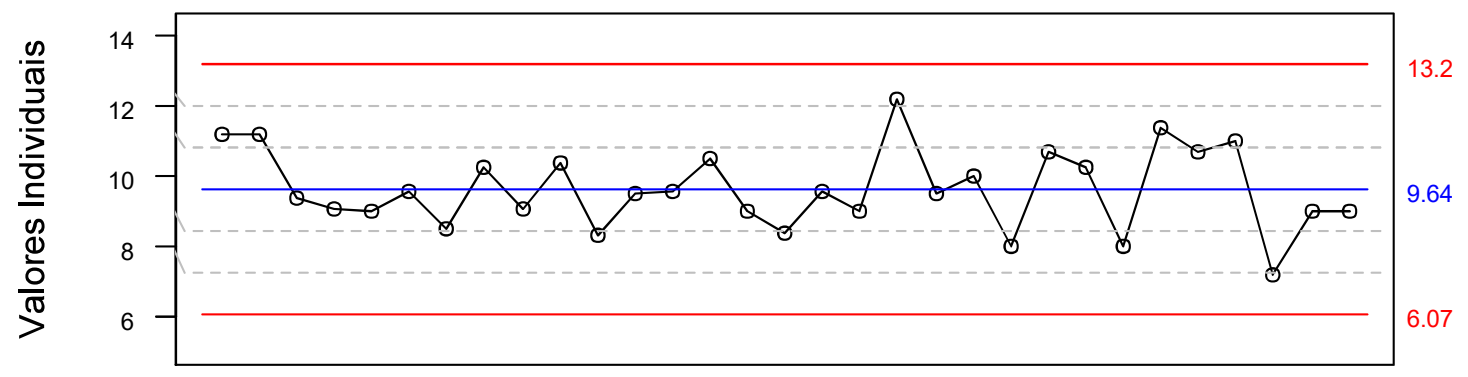


- $\mathrm{M} 3$

\section{Gráfico de Valores Individuais}

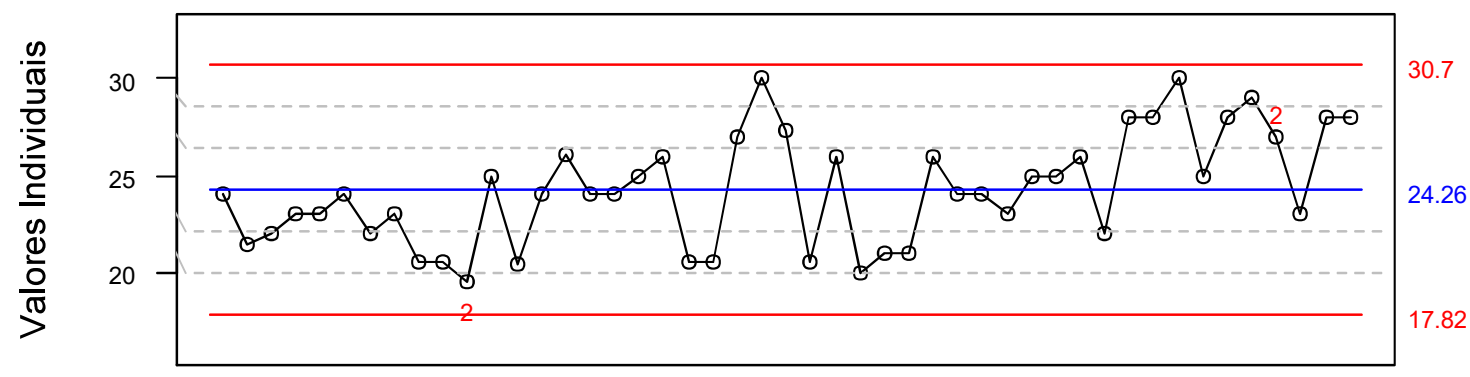

- M4

\section{Gráfico de Valores Individuais}

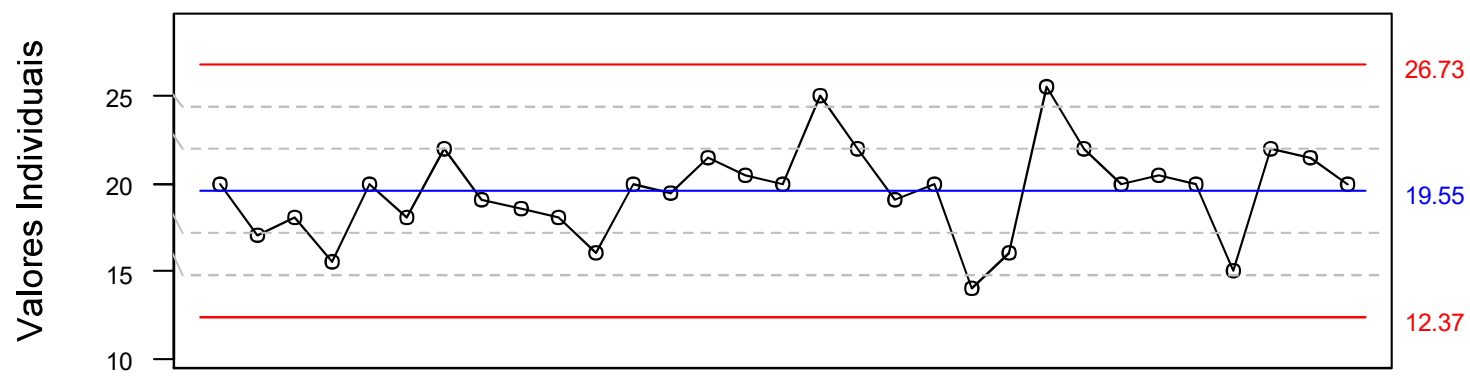

6. MSPA

- $\mathrm{M} 2$

\section{Gráfico de Valores Individuais}

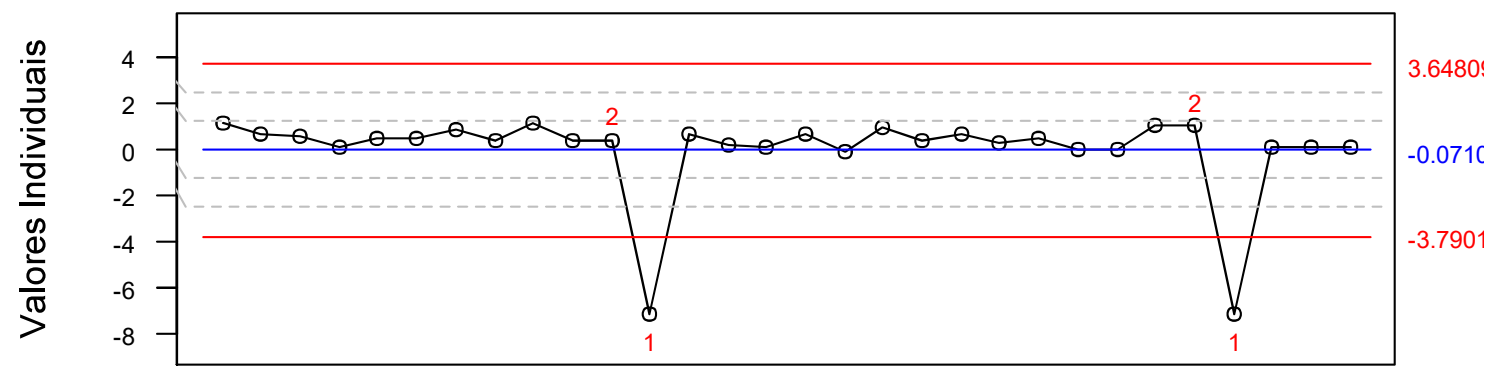


- $\mathrm{M} 3$

\section{Gráfico de Valores Individuais}

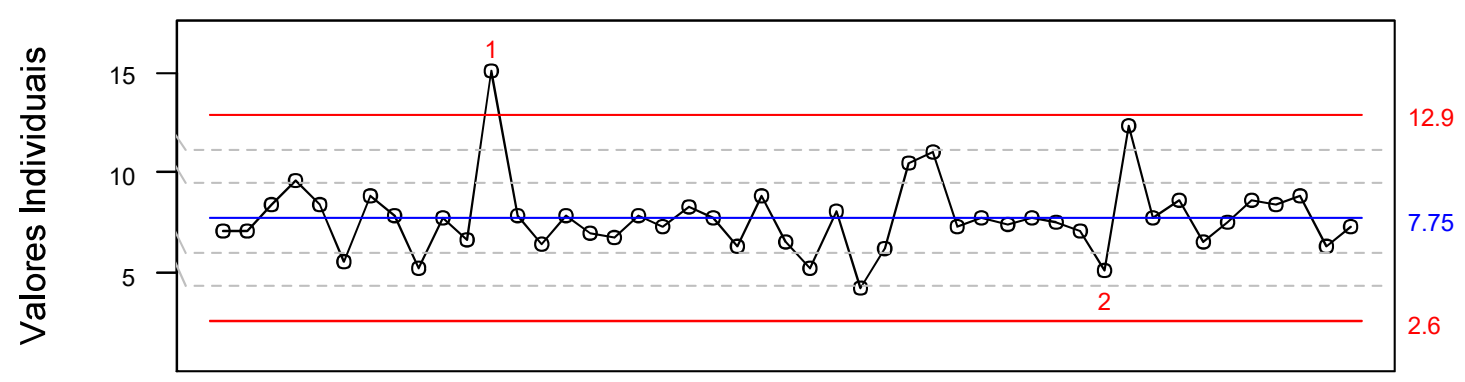

- M4

Gráfico de Valores Individuais

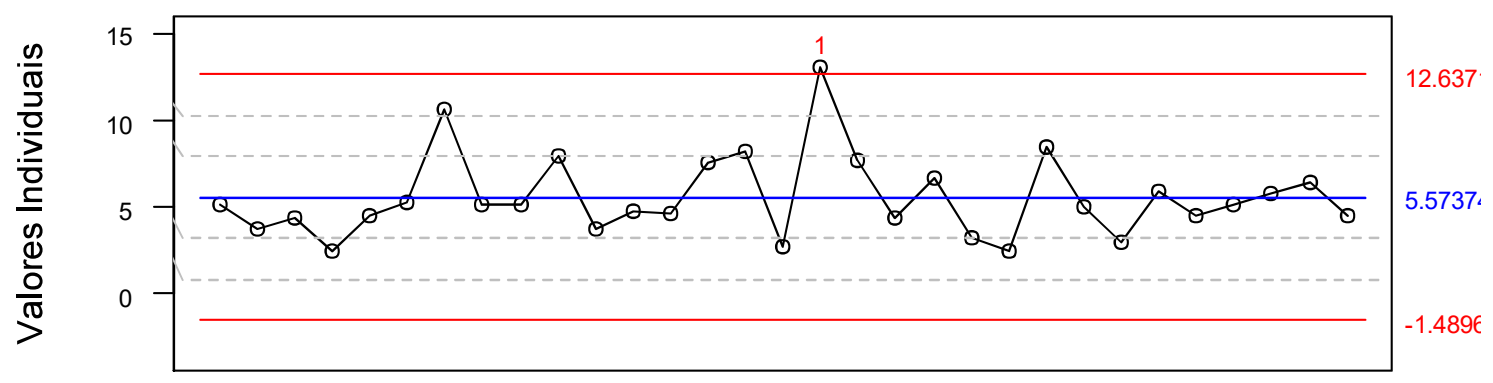

